UNIVERSIDADE DE SÃO PAULO

FACULDADE DE ARQUITETURA E URBANISMO DE SÃO PAULO

PROGRAMA DE PÓS-GRADUAÇÃO EM ARQUITETURA E URBANISMO

\title{
AS POLÍTICAS PÚBLICAS DE HABITAÇÃO DE INTERESSE SOCIAL NA PRODUÇÃO DO ESPAÇO URBANO |O CASO DA REGIÃO METROPOLITANA DE CAMPINAS|
}

Paula Francisca Ferreira da Silva São Paulo | 2016 


\section{PAULA FRANCISCA FERREIRA DA SILVA}

\section{AS POLÍTICAS PÚBLICAS DE HABITAÇÃO DE INTERESSE SOCIAL NA PRODUÇÃO DO ESPAÇO URBANO |O CASO DA REGIÃO METROPOLITANA DE CAMPINAS|}

Tese apresentada como requisito à obtenção do grau de Doutor em Arquitetura e Urbanismo no âmbito do Programa de Pós Graduação em Arquiteuta e Urbanismo da Universidade de São Paulo.

Área de concentração: Habitat

Orientadora: Profa. Dra. Maria Lúcia Refinetti Rodrigues Martins

\footnotetext{
EXEMPLAR REVISADO E ALTERADO EM RELAČ̃̃ À VERSÃO ORIGINAL, SOB RESPONSABILIDADE DO AUTOR E ANUÊNCIA DO ORIENTADOR. O original encontra-se disponível na sede do programa de pós-graduação. São Paulo,12 de agosto de 2016.
} 
AUTORIZO A REPRODUÇÃO E DIVULGAÇÃO TOTAL OU PARCIAL DESTE TRABALHO, POR QUALQUER MEIO CONVENCIONAL OU ELETRÔNICO, PARA FINS DE ESTUDO E PESQUISA, DESDE QUE CITADA A FONTE E O USO NÃO SEJA PARA FINS COMERCIAIS.

E-MAIL DA AUTORA: paula_ferreira_urb@yahoo.com.br paulafrancisca@usp.br

Silva, Paula Francisca Ferreira da

S586p As políticas públicas de habitação de interesse social na produção do espaço urbano |O caso da Região Metropolitana de Campinas| / Paula Francisca Ferreira da Silva . -- São Paulo, 2016.

209 p. : il.

Tese (Doutorado - Área de Concentração: Habitat) - FAUUSP.

Orientadora: Maria Lúcia Refinetti Rodrigues Martins

1.Habitação 2.Áreas metropolitanas - Campinas (SP)

3.Estruturas urbanas 4.Política habitacional I.Título

CDU 711.58 
Dedico este trabalho a todos aqueles que lutam pelo cumprimento dos direitos sociais. 


\section{AGRADECIMENTOS}

À CAPES (Coordenação de Aperfeiçoamento de Pessoal de Nível Superior), pelo apoio que tornou possível o desenvolvimento desta pesquisa.

À Profa. Dra. Malu Refinetti, por compreender minhas dificuldades, por me atender sempre com grande carinho e paciência; obrigada por não simplesmente orientar, mas discutir conceitos e compartilhar experiências, acima de tudo, agradeço a confiança no meu trabalho.

Aos Professores participantes do exame de qualificação, Prof. Dr. Eugenio Queiroga e Profa Dra Cibele Rizek, pelas preciosas contribuições para o desenvolvimento do trabalho.

Ao Prof. Dr. e pesquisador Jonathas Magalhães P. Silva, por ter sido tão generoso no início desta pesquisa, fornecendo mapas e discutindo questões conceituais.

À minha mãe, por ter me apoiado, acreditado que eu era capaz e por me auxiliar nas logísticas do dia-a-dia, fazendo comidinhas e organizando minha casa, para que eu pudesse me dedicar à pesquisa.

Ao meu pai, independente de onde esteja, por ter me guiado por meio de seus exemplos e do seu amor.

Ao meu amigo, amante e companheiro de todos os momentos, obrigada por compreender as minhas ausências, obrigada por me auxiliar sempre, desde as tarefas domésticas até o compartilhamento de leituras e, principalmente, obrigada por acreditar que eu conseguiria realizar este doutorado nos meus momentos de fraqueza.

À minha pequena filha, por existir.

Aos meus familiares, Ana Maria, Arlete, Sílvio, Berenice, Sérgio, Carlos, Lidiane e aos meus queridos jovens, Sheila Bruna, Ana Clara e Caio César, Priscilla e Larissa, por sempre estarem ao meu lado. Em especial ao Lucas, que me auxiliou em alguns mapeamentos.

À família de Santos, Juce e Mauro, Débora e Fabrício, Lícia e Fábio, e aos meus pequenos Felipe, Beatriz, Laura e Artur, o meu agradecimento pelo apoio e, principalmente, por compreenderem as minhas ausências.

À Profa. Dra. Jane Victal Ferreira, por ter despertado em mim o desejo pela pesquisa e por ser sempre amiga.

À Professora e arquiteta Ms. Christiane Lisboa, por estar ao meu lado nesta jornada, por ouvir minhas angústias e descobertas no desenvolvimento da pesquisa.

Às grandes amigas Beatriz Martinez, Joana Ribeiro, Márcia Prestes, Monica Escalante e Simone Polli, companheiras da pesquisa de habitação social, com as quais pude compartilhar momentos da pesquisa e contar com a amizade.

Aos meus amigos Cláudia Ribeiro, Conceição Tetzner, Daniela Scarassatti, Débora Pavanelli, Denise Álvares Bittar, Edilene Donadon, Lília Donadon, Luciana Margoni, Monica Moreno, Siomara Milanezi, Valéria Paiva, por me ouvirem tantas vezes falando sobre a pesquisa, pelo carinho, apoio e compreensão. Em especial, à arquiteta, amiga e ex-aluna Márcia Barbin, por me auxiliar no mapeamento de alguns elementos urbanos. 
À Maria Regina de Silos Nakamura, Tuti, pelo carinho e criteriosa revisão do texto.

À Débora Araujo, superintendente de habitação do município de Sumaré, por ter se revelado mais do que uma técnica municipal, mas uma grande amiga, com a qual pude compartilhar momentos da pesquisa.

A todos os técnicos municipais, por me atenderem prontamente e me auxiliarem no levantamento de dados. Sem a colaboração deles, este trabalho se tornaria impossível:

em Americana, Rosa Figueroba da Secretaria de Habitação e Marco Antonio Alves Jorge (Kim), secretário de Habitação de Americana;

em Arthur Nogueira, Daniela E. Gallo, do cadastro imobiliário e José Donizete Prado, secretário de Habitação e Urbanismo da Prefeitura de Artur Nogueira;

em Campinas, aos técnicos da COHAB Campinas, que me atenderam tão prontamente, e à Lina Dornelas de Camargo, Coordenadora Setorial de Planejamento Físico Habitacional da Secretaria de Habitação de Campinas;

em Cosmópolis, João Dias Damaceno Filho, diretor de Habitação e Margarete Caoracini da Silva, desenhista da Secretaria Municipal de Obras, Habitação e Planejamento Urbano;

em Engenheiro Coelho, Jéssica Forner de Oliveira e Tais Franco de Oliveira, do Departamento de Obras, Serviços e Planejamento Urbano;

em Holambra, Israel Aparecido Sarafim do Setor de Fiscalização e José Ricardo Cortez, diretor de Habitação de Holambra;

em Hortolândia, Bárbara Bosco da Secretaria de Habitação;

em Indaiatuba, Elisabete Cristina Canil, diretora de habitação e Edson José Suetake, da secretaria municipal de habitação;

em Itatiba, Camila Antonia Pereira Moreira Branco e Amarildo Nunes da Silva, da secretaria de Planejamento e Desenvolvimento;

em Jaguariúna, o Sr. Luiz Fernandes Maião, da secretaria de Planejamento; em Monte Mor, Vilson Amaral, secretário de Obras e Planejamento; em Morungaba, Engenheiro José Luis Frederico e Adriana Miguel, do Departamento de Obras e Serviços; em Nova Odessa, Tiago Logo, diretor de Habitação;

em Paulínia, Decival Benedito Ferreira da Secretaria de Planejamento, Desenvolvimento e Coordenação, Adriana Sueli Machi da Secretaria de Habitação e Paulo Busch, secretário de Habitação;

em Pedreira, Edson Luiz Nascimento, secretário de Promoção Social, Ana Paula Dias Franco de Oliveira e Dyane Cardoso de Souza Silva, da Secretaria de Promoção Social;

em Santa Bárbara d'Oeste, o arquiteto Thiago Luís Menillo, da Secretaria de Planejamento;

em Santo Antônio de Posse, Leonardo da Silva Granziera do departamento de Engenharia;

em Sumaré, Débora Araújo, superintendente de habitação e Carlos Shimabukuro, da Secretaria de Habitação;

em Valinhos, Pedro Luis Mayr, diretor do Departamento de Habitação;

em Vinhedo, Márcio Campos, secretário de habitação e Juliano Ferragutti, diretor de Habitação.

Também foi imprescindível para a realização do trabalho a colaboração do técnico da CDHU, Leobino Gomes de Souza Neto e Nilton José Dolce, líder de atendimento habitacional da regional Campinas da CDHU e dos técnicos da Caixa Econômica Federal (CEF), a Assistente Sênior da GE Habitação Campinas/SP, Maria Luisa Soliani Leite e do Coordenador de Filial da GE Habitação Campinas/ SP, Júlio Barboza Magalhães. 


\section{Resumo}

SILVA, Paula Francisca Ferreira. As Políticas Públicas de Habitação de Interesse

Social na Produção do Espaço Urbano | O Caso da Região Metropolitana de Campinas. Tese de Doutorado, Faculdade de Arquitetura e Urbanismo da USP, São Paulo, 2016.

A tese discute o significado da produção de Habitação de Interesse Social na constituição do espaço urbano e metropolitano da região de Campinas. Parte do pressuposto de que a determinação de implantação das Habitações de Interesse Social em determinadas áreas específicas das cidades por meio das políticas públicas é fundamental na estruturação urbana e metropolitana. A compreensão do quadro da expansão urbana através da produção e localização das Habitações de Interesse Social permite avaliar a importância das políticas habitacionais na constituição do desenho urbano e metropolitano. A partir de dados de fonte primária da produção de HIS nos vinte municípios da Região Metropolitana de Campinas: Americana, Artur Nogueira, Campinas, Cosmópolis, Engenheiro Coelho, Holambra, Hortolândia, Indaiatuba, Itatiba, Jaguariúna, Monte Mor, Morungaba, Nova Odessa, Paulínia, Pedreira, Santa Bárbara D'Oeste, Santo Antônio de Posse, Sumaré, Valinhos e Vinhedo, assim como de seus planos diretores, legislações referentes à habitação e do estudo da bibliografia pertinente, desenvolve-se análise de como essas políticas públicas se manifestaram no espaço físico da cidade, quais foram as lógicas da ocupação territorial e as relações entre as políticas habitacionais e a expansão metropolitana do território. O trabalho abrange o período que se estende de 1964, ano de criação do Banco Nacional de Habitação $(B N H)$, até 2014, momento em que as implantações decorrentes do Programa Minha Casa Minha Vida, Lei Federal no 11.977 de 2009, já são visíveis e perceptíveis. A pouca consideração, pelos diferentes municípios, da condição metropolitana, dos fluxos, dos processos de uso, ocupação e localização no território resulta na elaboração de políticas públicas que, além de desarticuladas entre si e desconectadas enquanto territórios, não correspondem às realidades urbanas e metropolitanas da região de Campinas. Assim, ressalta-se o quanto as políticas habitacionais deixam de atender às questões colocadas pelo território e o quanto poderiam ser potencializadoras de uma melhor forma de expansão urbana do mosaico de municípios que compõem a RMC.

Palavras-chave: Habitação de Interesse Social; Região Metropolitana de Campinas; estruturação urbana; política habitacional. 


\section{Abstract}

SILVA, Paula Francisca Ferreira. As Políticas Públicas de Habitação de Interesse Social na Produção do Espaço Urbano | O Caso da Região Metropolitana de Campinas. Tese de Doutorado, Faculdade de Arquitetura e Urbanismo da USP, São Paulo, 2016.

The thesis discusses the role and meaning of Social Housing oficial initiatives in the Metropolitan Region of Campinas urban spaces and metropolitan area. It starts by assuming that inserting Social Housing projects in certain urban areas following metropolitan and municipal housing policies is indispensable to structure and organize urban and metropolitan spaces. By understanding the urban expansion through mapping and analysing every social housing settlement in the region, it is possible to assess the social housing policies importance concerning metropolitan organization and urban design. Assessing primary source data scoping social housing established in twenty cities of the Campinas Metropolitam Region: Americana, Artur Nogueira, Campinas, Cosmópolis, Engenheiro Coelho, Holambra, Hortolândia, Indaiatuba, Itatiba, Jaguariúna, Monte Mor, Morungaba, Nova Odessa, Paulínia, Pedreira, Santa Bárbara D'Oeste, Santo Antônio de Posse, Sumaré, Valinhos e Vinhedo, the city master plans and urban laws and policies on housing and related bibliography, the study analyzed how such housing policies are expressed in the urban environment, aiming to find the territorial occupation logic and relations between the public policies regarding social housing projects and the urbanized expansion in the metropolitan territory. The study examines the period between 1964 when the National Housing Bank, BNH, was established and 2014 when social housing projects built under the National Housing Project "Minha Casa Minha Vida" created by the federal law 11.977 (2009) may have already been noticed in the area. Municipal policies of each of twenty cities have had little concern about the metropolitan situation, people, goods and resources flows, land use, occupancy and locating processes, that besides being detached and locally disconnected do not correspond to the urban reality of each city and the metropolitan area as a whole. Thus, it is evident how much the housing policies fail to answer the demands and requirements of territorial occupation, instead of improving and proposing urban developments and expansion policies for the large mosaic of cities that constitute the Metropolitan Region of Campinas.

Key words: Social Housing, Metropolitan Region of Campinas, urban structuration, housing policy. 


\section{Lista de Mapas}

Mapa 1 - A Região Metropolitana de Campinas | mancha urbana e as principais rodovias ___ 27

Mapa 2 - Região Metropolitana de Campinas e a população em 2010 __ 33

Mapa 3 - Municípios da RMC quanto à instituição de ZEIS (nos planos diretores) __ 59

Mapa 4 - Municípios conforme a quantidade de instrumentos para HIS em seus planos diretores___ 64

Mapa 5 - Municípios que possuem Fundo Municipal de Habitação, Conselho e PLHIS___ 71

Mapa 6 - Munícipios da RMC em que as HIS foram mapeadas na primeira etapa para desenvolvimento da metodologia

Mapa 7 - Habitações de Interesse Social produzidas em Americana (1964-2014) - limite municipal ___ 140

Mapa 8 - Habitações de Interesse Social produzidas em Campinas (1964-2014) - limite municipal___ 141

Mapa 9 - Habitações de Interesse Social produzidas em Itatiba (1964-2014) - limite municipal ___ 142

Mapa 10 - Habitações de Interesse Social produzidas em Itatiba (1964-2014) - área urbanizada ___ 143

Mapa 11 - Habitações de Interesse Social produzidas em Santa Bárbara d’Oeste (1964-2014) - limite municipal

Mapa 12 - Habitações de Interesse Social produzidas em Sumaré (1964-2014) - limite municipal ___ 145

Mapa 13 - Habitações de Interesse Social produzidas em Hortolândia (1964-2014) - limite municipal__ 148

Mapa 14 - Habitações de Interesse Social produzidas em Nova Odessa (1964-2014) - limite municipal __ 149

Mapa 15 - Habitações de Interesse Social produzidas em Pedreira (1964-2014) - limite municipal___ 150

Mapa 16 - Habitações de Interesse Social produzidas em Valinhos (1964-2014) - limite municipal___ 151

Mapa 17 - Habitações de Interesse Social produzidas em Paulínia (1964-2014) - limite municipal ___ 153

Mapa 18 - Habitações de Interesse Social produzidas em Vinhedo (1964-2014) - limite municipal___ 154

Mapa 19 - Habitações de Interesse Social produzidas em Artur Nogueira (1964-2014) - limite municipal _ 156

Mapa 20 - Habitações de Interesse Social produzidas em Cosmópolis (1964-2014) - limite municipal __ 157

Mapa 21 - Habitações de Interesse Social produzidas em Indaiatuba (1964-2014) - limite municipal __ 158

Mapa 22 - Habitações de Interesse Social produzidas em Jaguariúna (1964-2014) - limite municipal ___ 159

Mapa 23 - Habitações de Interesse Social produzidas em Engenheiro Coelho (1964-2014) - limite municipal

Mapa 24 - Habitações de Interesse Social produzidas em Holambra (1964-2014) - limite municipal

Mapa 25 - Habitações de Interesse Social produzidas em Monte Mor (1964-2014) - limite municipal __ 164

Mapa 26 - Habitações de Interesse Social produzidas em Monte Mor (1964-2014) - área urbanizada _ 165

Mapa 27 - Habitações de Interesse Social produzidas em Morungaba (1964-2014) - limite municipal __ 166

Mapa 28 - Habitações de Interesse Social produzidas em Morungaba (1964-2014) - área urbanizada __ 167

Mapa 29 - Habitações de Interesse Social produzidas em Santo Antônio de Posse (1964-2014) - limite municipal

Mapa 30 - Habitações de Interesse Social produzidas em Santo Antônio de Posse (1964-2014) - área

urbanizada

Mapa 31 - Vetores de Expansão da Região Metropolitana de Campinas___ 174

Mapa 32 - Vetores de Expansão da RMC (incluindo Morungaba)___ 178

Mapa 33 - As Habitações de Interesse Social produzidas na Região Metropolitana de Campinas entre 1964 e 2014

Mapa 34 - As Habitações de Interesse Social na RMC e alguns elementos estruturadores do espaço urbano

\section{Lista de Figuras}

Figura 1 - Foto aérea da cidade de Pedreira (entorno, a partir da R. Mascarenha de Moraes)

Figura 2 - Foto aérea de Pedreira (possível perímetro do conjunto de HIS Vila Monte Alegre)

Figura 3 - Localização da HIS Monte Alegre em Pedreira (exemplo de como as informações são vinculadas aos perímetros dos conjuntos habitacionais) 


\section{Lista de Tabelas}

Tabela 1 - População (urbana e rural), área e densidade demográfica | os municípios da RMC __ 32

Tabela 2 - PIB dos municípios da RMC em 2010___ 34

Tabela 3 - Índice de Gini dos municípios da Região Metropolitana de Campinas ___ 35

Tabela 4 - Municípios da RMC por faixas de rendimento ___ 36

Tabela 5 - Percentual do Valor Adicionado Total por setor de atividade - municípios da RMC __ 37

Tabela 6 - Dados das Habitações de Interesse Social produzidas em Americana (1964-2014) ___ 76

Tabela 7 - Dados das Habitações de Interesse Social produzidas em Artur Nogueira (1964-2014)___ 80

Tabela 8 - Dados das Habitações de Interesse Social produzidas em Campinas (1964-2014)____ 81

Tabela 9 - Dados das Habitações de Interesse Social produzidas em Cosmópolis (1964-2014) ___ 92

Tabela 10 - Dados das Habitações de Interesse Social produzidas em Engenheiro Coelho (1964-2014) __ 94

Tabela 11 - Dados das Habitações de Interesse Social produzidas em Holambra (1964-2014)___ 94

Tabela 12 - Dados das Habitações de Interesse Social produzidas em Hortolândia (1964-2014)___ 95

Tabela 13 - Dados das Habitações de Interesse Social produzidas em Indaiatuba(1964-2014) ___ 97

Tabela 14 - Dados das Habitações de Interesse Social produzidas em Itatiba (1964-2014)___ 100

Tabela 15 - Dados das Habitações de Interesse Social produzidas em Jaguariúna (1964-2014) ___ 101

Tabela 16 - Dados das Habitações de Interesse Social produzidas em Monte Mor (1964-2014) ___ 102

Tabela 17 - Dados das Habitações de Interesse Social produzidas em Morungaba (1964-2014) ___ 102

Tabela 18 - Dados das Habitações de Interesse Social produzidas em Nova Odessa (1964-2014) ___ 103

Tabela 19 - Dados das Habitações de Interesse Social produzidas em Paulínia (1964-2014) ___ 104

Tabela 20 - Dados das Habitações de Interesse Social produzidas em Pedreira (1964-2014) ___ 106

Tabela 21 - Dados das Habitações de Interesse Social produzidas em Santa Bárbara d'Oeste (1964-2014) 107

Tabela 22 - Dados das Habitações de Interesse Social produzidas em Santo Antônio de Posse (1964-2014) 109

Tabela 23 - Dados das Habitações de Interesse Social produzidas em Sumaré (1964-2014)___ 109

Tabela 24 - Dados das Habitações de Interesse Social produzidas em Valinhos (1964-2014)____ 111

Tabela 25 - Dados das Habitações de Interesse Social produzidas em Vinhedo (1964-2014) ___ 113

Tabela 26 - Número de unidades habitacionais produzidas na RMC de 1964 até $2014 \_119$

Tabela 27 - Total de HIS e total de domicílios urbanos até cada período analisado ___ 121

Tabela 28 - Percentual de Habitação de Interesse Social em relação ao total de domicílios urbanos nos municípios da Região Metropolitana de Campinas

Tabela 29 - Quantidade de conjuntos de HIS e de unidades habitacionais de interesse social levantados e mapeados na pesquisa 136

\section{Lista de Quadros}

Quadro 1 - Municípios que instituem ZEIS em seus planos diretores 42

Quadro 2 - Parâmetros estabelecidos para HIS nos municípios que instituem ZEIS _ 50

Quadro 3 - Municípios que não instituem ZEIS por meio dos planos diretores ___

Quadro 4 - Planos diretores (vigentes em 2014) e sua relação com Habitação de Interesse Social ___ 65

Quadro 5 - Leis de Fundo, Conselho e Plano Local de Habitação dos municípios da Região Metropolitana de

Campinas.

Quadro 6 - Material fornecido pelas instituições para o mapeamento das HIS em cada município da RMC

(1964-2014) 


\section{Lista de Siglas e Abreviaturas}

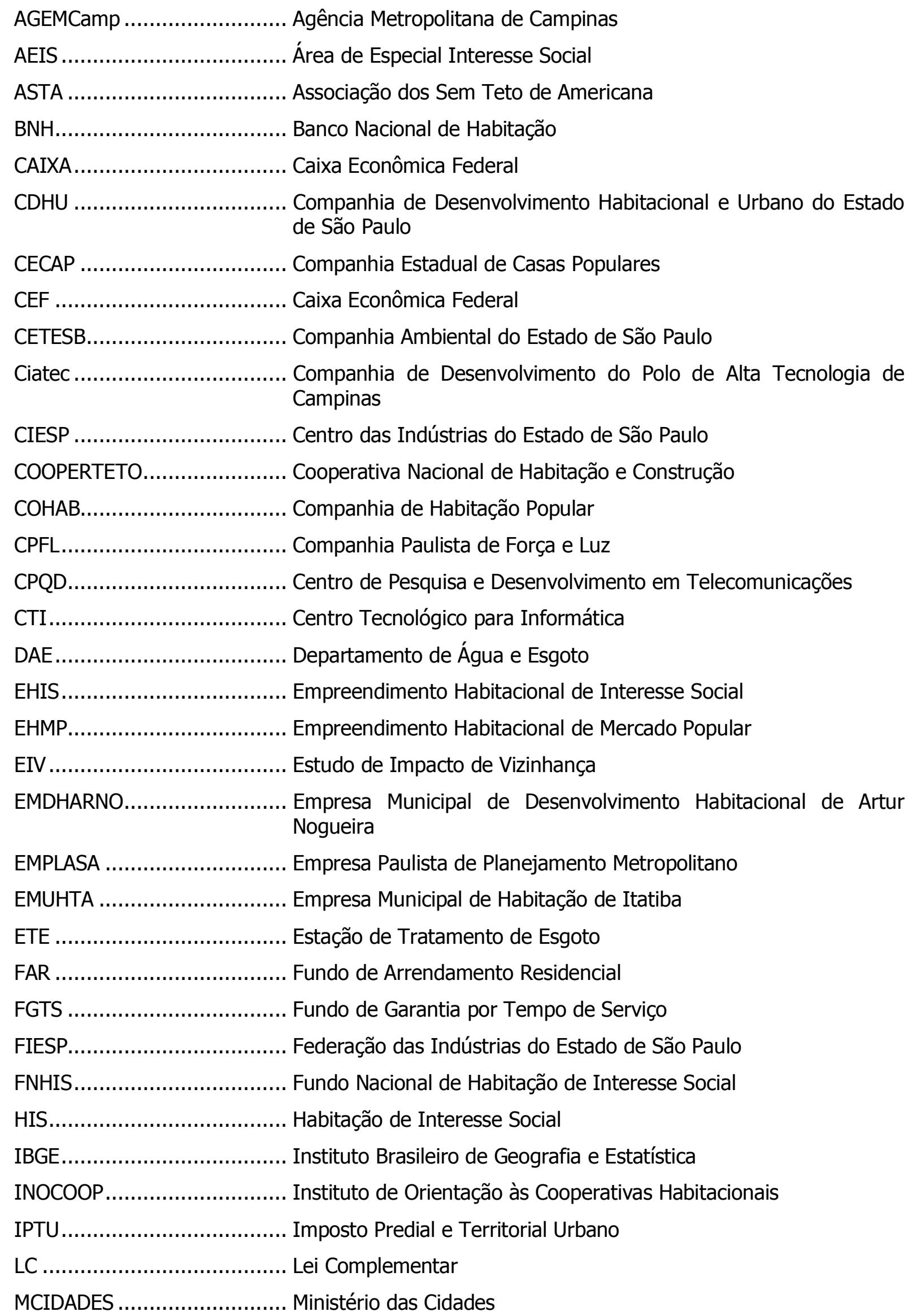




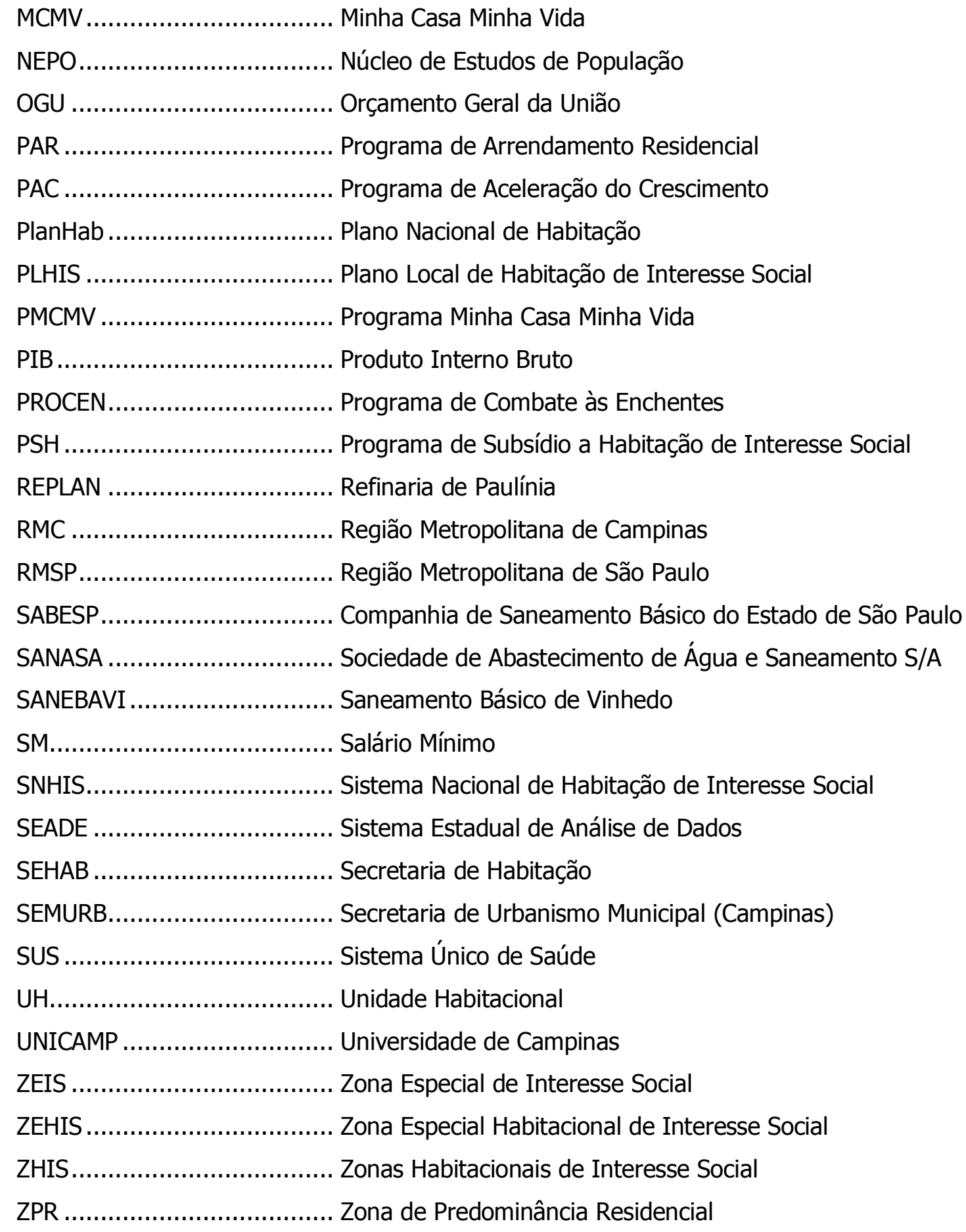




\section{SUMÁRIO}

Introdução 14

CAPÍTULO I / Política de Habitação no Brasil e na Região Metropolitana de Campinas 20

1.1 O contexto institucional: do BNH ao MCMV 20

1.2 Metropolização e Habitação de Interesse Social | A Região Metropolitana de Campinas 25

1.2.1 Dados da Região Metropolitana de Campinas 31

CAPÍTULO II I Os municípios da Região Metropolitana de Campinas e seu aparato legal para a produção de Habitação de Interesse Social

2.1 Planos Diretores nos Municípios da RMC 39

2.1.1. Os meandros do instrumento ZEIS na Região Metropolitana de Campinas 40

2.1.1.1 ZEIS: municípios que as instituem e a quem se destinam _ 41

2.1.1.2 ZEIS etérea nos Planos Diretores

2.1.1.3 Municípios que não estabelecem ZEIS _ 55

2.1.1.4 Análise do instrumento ZEIS nos planos diretores da RMC

2.1.1. A Diversidade de Instrumentos Urbanísticos voltados à Habitação de Interesse Social na RMC 60

2.2 Leis de Fundo, Conselho e Plano Habitacional | Municípios da RMC _ 66

2.1 Considerações sobre as Regulamentações Municipais para Habitação de Interesse Social na RMC72

Capítulo III - A produção de Habitação de Interesse Social na Região Metropolitana de Campinas 73

3.1 Conjuntos habitacionais produzidos na RMC de 1964 a $2014 \_74$

3.2 Casos especiais de produções de Habitação de Interesse Social na RMC __ 114

3.2.1 Casas em Comodato | município de Pedreira __ 114

3.2.2 Limites tênues entre poder público e iniciativa privada | município de Americana ___ 115

3.2.3 Casas vendidas em processo de construção | município de Campinas ___ 117

3.3 Municípios que se destacam na produção de HIS na RMC _ 118

Capítulo IV - A implantação das Habitações de Interesse Social na RMC de 1964 a 2014126

4.1. Desenvolvimento de Metodologia para o Mapeamento das Habitações de Interesse Social

\begin{tabular}{lll}
\hline 4.2 & Habitações de Interesse Social e estruturação urbana & 137 \\
4.2.1 & A escala municipal: implantação das HIS no tecido urbano \\
4.2.1 & A escala metropolitana: implantação das HIS no contexto da Região Metropolitana de Campinas \\
& 172
\end{tabular}

Considerações Finais 188

Referências 193

Anexos 209

Coletânea das Regulamentações Municipais da RMC 209

Mapa em arquivo digital das HIS realizadas na RMC entre 1964 e 2014 209 


\section{Introdução}

O significado das Habitações de Interesse Social na expansão urbana da Região Metropolitana de Campinas (RMC) assim como as políticas públicas que orientam sua implantação, deliberadamente ou não, são os objetos de estudo desta pesquisa. Ainda que se considere o conjunto de políticas e instrumentos utilizados para a formatação de políticas públicas, trabalha-se não com uma análise do "planejamento", mas do efetivo produto.

Para tanto, a pesquisa conta com um abrangente e consistente levantamento de dados lançados em mapa, o que permite uma visualização das dimensões e da localização das unidades habitacionais implantadas.

Assim, um primeiro desafio é o estabelecimento do que se compreende por Habitação de Interesse Social e por políticas públicas que as produzem. Considera-se, para tanto, o conjunto de iniciativas que configuram a produção de Habitação de Interesse Social, entendida como um produto promovido pelo Estado, com aporte direto, subsídio, apoio, financiamento facilitado ou outras modalidades, oferecendo um produto que escapa em alguma medida às regras puramente concorrenciais do mercado. Inscrevem-se numa condição de comercialização, em que a demanda deve qualificar-se como dentro de uma faixa de renda considerada baixa, para o que se utilizaram critérios que variaram um tanto ao longo do tempo e dos programas.

O trabalho abrange o período que se estende de 1964, ano de criação do Banco Nacional de Habitação (BNH), até 2014, quando podem ser percebidas as implantações decorrentes do Programa Minha Casa Minha Vida, Lei Federal no 11.977 de 2009.

A Lei 4.380 de 1964, que cria o Banco Nacional de Habitação e o Serviço Federal de Habitação e Urbanismo, dispõe em seu artigo $1^{0}$ que "O Govêrno Federal, através do Ministro de Planejamento, formulará a política nacional de habitação e de planejamento territorial, coordenando a ação dos órgãos públicos e orientando a iniciativa privada no sentido de estimular a construção de habitações de interêsse social e o financiamento da aquisição da casa própria, especialmente pelas classes da população de menor renda". Naquele momento, entendia-se como a faixa de renda a ser contemplada pela Habitação de Interesse Social a de 0 a 6 salários mínimos. Por ocasião do lançamento do Minha Casa Minha Vida, em 2009, definiram-se algumas faixas em que a beneficiária de subsídios diretos, não reembolsáveis, provenientes do Orçamento Geral da União, era a de 0 a 3 salários mínimos. 
O termo Habitação de Interesse Social, presente desde a criação do BNH, voltou a ser qualificado a partir de projeto de lei de iniciativa popular de 1991, que propunha a criação do Fundo Nacional de Habitação de Interesse Social. A partir dessa proposta, foi aprovada, mais de uma década depois de sua apresentação, a Lei no 11.124 de 2005, que dispõe sobre o Sistema Nacional de Habitação de Interesse Social - SNHIS, cria o Fundo Nacional de Habitação de Interesse Social - FNHIS e institui o Conselho Gestor do FNHIS.

Para a análise, foi levantada a Lei Federal 11.124 de 2005, que trata do Sistema Nacional de Habitação de Interesse Social, do Fundo Nacional de Habitação de Interesse Social, do seu Conselho Gestor e do Plano Nacional de Habitação de Interesse Social, aprovado em dezembro de 2009. Além disso, foram levantados os planos diretores dos 20 municípios que compõem a RMC, assim como as leis municipais que criam fundo, conselho e plano municipais de habitação. Em alguns casos, a leitura dessas regulamentações conduziu à necessidade de pesquisar outras regulamentações municipais, como leis específicas relacionadas à habitação, às leis de uso e ocupação do solo e ao zoneamento.

Para o desenvolvimento deste trabalho, foram realizadas a sistematização e a análise das regulamentações voltadas à habitação, assim como o levantamento da produção das habitações de interesse social nos 20 municípios da Região Metropolitana de Campinas (RMC) e o seu mapeamento no território. Foram pesquisadas todas as habitações de interesse social construídas como conjunto a partir de programas públicos, de 1964 a 2014.

Torna-se importante observar que os termos habitações de interesse social ou conjunto de habitações de interesse social, ou ainda empreendimentos habitacionais de interesse social, conforme é entendido neste trabalho, compreendem-se como um grupo de unidades habitacionais produzidas a partir de programas públicos, que podem ser municipais, estaduais ou federais ou acontecerem por meio de coparticipação com outras entidades, inclusive privadas. Considera-se, portanto, não apenas a produção de unidades, mas outros programas públicos que suscitam a produção de unidades, como é o caso da cessão de lotes urbanizados.

Cabe lembrar que a escala dos conjuntos habitacionais levantados é bastante diversa, pois esses conjuntos estão localizados em municípios cuja população varia de 12 mil habitantes (em 2013) a mais de 1 milhão ${ }^{1}$, o que reflete na escala de implantação dos conjuntos habitacionais. A partir do trabalho empírico de levantamento dos conjuntos, foram mapeados todos os conjuntos habitacionais de interesse social com mais de dez unidades,

\footnotetext{
${ }^{1}$ Os números referem-se à população estimada para os municípios em 2013, segundo o IBGE. Ver nesta tese: Tabela 1 - População (urbana e rural), área e densidade demográfica | os municípios da RMC (p. 32).
} 
pois se considera, no contexto deste trabalho, que conjuntos de porte menor não têm grande significado no tecido urbano.

Por meio do levantamento e mapeamento desses conjuntos, objetivou-se a construção de um quadro-síntese do território, a partir do qual foi possível relacionar o que ocorre no território urbano e metropolitano com as políticas públicas habitacionais. Tomando o período entre 1964 e 2014, foram identificados 504 conjuntos de Habitação de Interesse Social na RMC, dos quais 494 foram mapeados.

Com esse mapeamento, foi possível discutir questões como a existência de padrões de ocupação dos empreendimentos de Habitação de Interesse Social, o processo de expansão urbana da RMC por meio desses empreendimentos, as relações entre a localização dos empreendimentos e a instituição de diversas políticas públicas habitacionais, a análise de como esse conjunto de políticas regula ou não o território e sobre a coerência entre essas políticas e a forma metropolitana de ocupação territorial. Pretende-se perceber em que medida as políticas públicas habitacionais federais, estaduais, metropolitanas e municipais são capazes de impactar ou dirigir a configuração da estrutura urbana ${ }^{2}$. Embora muitas vezes os planos e políticas habitacionais não discutam a questão territorial e espacial, eles produzem habitações e, portanto, a cidade.

É importante destacar que, para o desenvolvimento da análise proposta, um estudo de caso que não contemplasse todos os municípios da RMC seria incoerente com as questões colocadas, uma vez que se pretende a leitura da região como um todo. A lei estadual $^{3}$ que cria regiões metropolitanas considera a existência de fluxos pendulares de trabalhadores e de questões econômicas e territoriais correlacionadas entre os municípios que as constituem. Portanto, busca-se realizar a leitura das questões habitacionais no mosaico de municípios da RMC, pois quaisquer desmembramentos não seriam condizentes com a direção adotada por esta pesquisa, que trata de questões referentes a um tipo de expansão urbana que ocorre perpassada por lógicas que se sobrepõem às divisões legais dos municípios. O estudo, portanto, compreendeu os vinte municípios, a despeito das

\footnotetext{
2 Para explicitar o entendimento de "estrutura urbana", adota-se a referência de Villaça: A estruturação do espaço "intraurbano" se define a partir do deslocamento do ser humano, seja enquanto portador da mercadoria força de trabalho ou enquanto consumidor. Já o espaço regional tem a sua estrutura dominada pelo deslocamento das informações, da energia, do capital e das mercadorias em geral (VILLAÇA, 1998, p. 17-22).

3 "Considera-se região metropolitana o agrupamento de Municípios limítrofes que assuma destacada expressão nacional, em razão de elevada densidade demográfica, significativa conurbação e de funções urbanas e regionais com alto grau de diversidade, especialização e integração sócio-econômica, exigindo planejamento integrado e ação conjunta permanente dos entes públicos nela atuantes" (artigo 153, § 10, Constituição Estadual de São Paulo, 1989).
} 
dificuldades decorrentes da extensão da área da RMC e dos diferentes tipos de informações disponíveis nos municípios.

No contexto de expansão urbana e de diversidade metropolitana, a formulação de políticas públicas habitacionais não pode mais restringir o conceito de cidade ao modelo centro-periferia de expansão, ou seja, torna-se essencial pensar a habitação de forma metropolitana, tanto no que se refere à ocupação do território quanto à articulação das diferentes instâncias de governo, como colocado pelo Estatuto da Cidade, aprovado pela Lei Federal no 10.257/2001. É preciso compreender a lógica metropolitana de ocupação no território dos conjuntos habitacionais de interesse social tendo como parâmetro que o lugar que as pessoas ocupam na cidade tem um valor econômico, cultural e político.

Existem diversos estudos e publicações a respeito de políticas públicas voltadas para Habitação de Interesse Social que tratam da história de implementação de tais políticas. Embora alguns façam referência aos efeitos territoriais, não há trabalhos que relacionem de forma direta essas políticas ao processo de expansão territorial na RMC, contemplando a localização dos empreendimentos na região, o que constitui o enfoque proposto pelo presente trabalho.

A pesquisa procurou evidenciar a importância da política de habitação e de seus programas na estruturação urbana, tomando como caso a Região Metropolitana de Campinas. A política habitacional no Brasil é atribuição dos três entes federativos: União, estados e municípios. Os municípios de uma região metropolitana, a despeito de comporem um todo que possui uma lógica de expansão e fluxos de caráter metropolitano, possuem também especificidades e necessidades bastante diferentes, que pressupõem ações e tratamentos distintos.

Nas regiões metropolitanas o que se observa é que as políticas e programas de habitação se justapõem de forma desarticulada entre si e desconectada com relação ao território. Para efeito de comparação, enquanto a estrutura do Sistema Único de Saúde (SUS) foi capaz de conceber uma política nas três esferas de governo, que articulou atribuições de cada nível e distribuição territorial da rede de equipamentos, nada semelhante existe para o setor da habitação.

A pesquisa trabalha com a hipótese de que a implantação dos conjuntos habitacionais de interesse social é elemento fundamental na estruturação urbana e metropolitana, tomando como princípio que a compreensão da lógica de implantação de conjuntos habitacionais de interesse social da RMC ultrapassa os limites administrativos municipais. 
Há elementos para se avaliar que as políticas públicas habitacionais foram decisivas na constituição do desenho urbano dos municípios, bem como na estruturação urbana e metropolitana da região de Campinas.

A tese se estrutura em quatro capítulos. No Capítulo I, são apresentadas as origens da habitação social no Brasil, retomando como a habitação popular era compreendida ou até mesmo desconsiderada enquanto objeto de ação do Estado antes de 1964. Na sequência, apresenta-se o histórico da política habitacional no Brasil, desde 1964, com a instituição do BNH, até 2009, com a aprovação do Programa Minha Casa Minha Vida. Na sequência, apresenta-se a Região Metropolitana de Campinas desde 1970 até sua institucionalização, em 2000; discutem-se, também, a gestão metropolitana, o plano metropolitano de habitação e a diversidade dos municípios que compõem a RMC, caracterizando-os por meio de alguns dados estatísticos, como população, PIB, renda per capita e setores de atividade.

No Capítulo II, são discutidos os planos diretores dos vinte municípios da RMC no que se referem à Habitação de Interesse Social, com enfoque no instrumento ZEIS (Zonas Especiais de Interesse Social). Na sequência, são apresentadas as leis de fundo, de conselho e os planos locais de habitação, pois, com essa tríade, podem ser obtidos recursos do Fundo Nacional de Habitação de Interesse Social (FNHIS). Realiza-se uma análise dos municípios com relação ao aparato legal para a produção de Habitação de Interesse Social, sendo os municípios agrupados conforme o seu nível de instrumentalização para a produção de HIS. Além da análise da bibliografia existente, grande parte do texto desse capítulo foi elaborado a partir de fonte primária, ou seja, das legislações dos vinte municípios da RMC.

No Capítulo III, são apresentados os conjuntos habitacionais realizados na Região Metropolitana de Campinas de 1964 até 2014. Primeiramente, explicitam-se as dificuldades e metodologia que permearam o levantamento de dados e, na sequência, são apresentadas vinte tabelas com a produção de HIS de cada um dos municípios da RMC. No segundo item, são abordados três casos especiais de produção de HIS na RMC: Pedreira, Americana e Campinas, onde houve formas não convencionais nos processos de produção dessas habitações. E, por último, são analisados os municípios e períodos em que houve maior produção de HIS, e os municípios que apresentaram maior produção em cada período são relacionados com os grupos de municípios que dispuseram de maior quantidade de instrumentos em seus planos e leis, conforme discutido no segundo capítulo. Buscou-se perceber como a regulamentação refletiu ou não no território e na implantação das HIS.

O Capítulo IV trata da implantação das Habitações de Interesse Social nos municípios da RMC. Primeiramente, aborda-se a questão do levantamento, as diversas formas de 
obtenção dos dados relativos à localização dessas habitações e as decisões metodológicas adotadas para o mapeamento dos perímetros dos conjuntos dessas HIS. Ressalta-se que a descrição dessa metodologia é importante para o estudo realizado sobre a produção habitacional, pois explicita os critérios utilizados para o mapeamento, evitando, assim, possíveis distorções de compreensão da análise empreendida. Em um segundo item, discutem-se as relações entre a implantação das HIS no território e a estrutura urbana e metropolitana. São analisadas essas relações em duas escalas: a municipal, a partir dos perímetros, e a metropolitana, a partir dos eixos de expansão urbana da RMC.

Considera-se que uma relevante contribuição da tese é a disponibilização de mapas com a localização exata e os perímetros dos conjuntos de habitação produzidos, dando visibilidade à importância das políticas de habitação na configuração da estrutura urbana e metropolitana. As considerações finais abrangem as discussões das questões lançadas como hipótese e os elementos que explicitam o quanto a implantação de Habitações de Interesse Social é relevante na estruturação urbana hoje presente na Região Metropolitana de Campinas, o que certamente pode ser verificado nas demais estruturas metropolitanas do país. 


\section{CAPÍTULO I | Política de Habitação no Brasil e na Região Metropolitana de Campinas}

\subsection{O contexto institucional: do BNH ao MCMV}

A política habitacional no Brasil possui alguns importantes antecedentes históricos, mas é apenas com a criação do Banco Nacional de Habitação - BNH e do Sistema Financeiro da Habitação - SFH, em 1964, que ocorre uma produção em massa, num contexto institucional e financeiro desenhado para esse fim. Entre seus principais objetivos, estava também se configurar como um amplo projeto de desenvolvimento econômico e geração de emprego.

A nova política contemplava a necessidade de estimular o importante setor industrial - o da construção civil, e com isto absorver significativo número de empregados sem qualificação profissional, amenizando as possíveis pressões contra o desemprego que o controle a inflação ameaçava provocar (FINEPGAP, 1985, p. 88).

A política habitacional do Banco Nacional de Habitação (BNH), portanto, dinamiza a economia, por meio da geração de empregos e fortalecimento do setor da construção civil. O Sistema Financeiro de Habitação (SFH) estrutura-se a partir dos recursos gerados pela criação, em 1967, do Fundo de Garantia por Tempo de Serviço (FGTS) ${ }^{4}$, alimentado pela poupança compulsória de todos os assalariados brasileiros, que se somam aos recursos da poupança voluntária e contribuem para a formação o Sistema Brasileiro de Poupança e Empréstimo (SBPE). Naquele momento, define-se uma estrutura institucional de abrangência nacional, paralela à administração direta, formada pelo BNH e por uma rede de agentes promotores e financeiros (privados e estatais), capaz de viabilizar em grande escala as ações necessárias para a implementação do plano na área habitacional. Gabriel Bolaffi (1982, p. 46) comenta a estratégia do FGTS para obtenção de recursos:

\footnotetext{
O sistema engendrado em torno do BNH conseguiu superar o impasse, por meio de uma fórmula que canalizaria para a construção civil recursos gerados no próprio setor privado. Ao mesmo tempo, o setor privado foi liberado do ônus para o qual os recursos absorvidos estavam destinados. [...] os recursos não inflacionários que poderiam estimular a construção civil originaram-se, principalmente do FGTS [...] Embora implicando em um ônus de 8 por centro sobre o total dos salários pagos, a criação dos FGTS praticamente não onerou as empresas privadas, pois libertou-as das reservas necessárias para o pagamento das indenizações compulsórias.
}

\footnotetext{
${ }^{4}$ O FGTS é administrado pelo BNH até sua extinção em 1986, quando passa a ter sua gestão operacional pela Caixa Econômica Federal e sua gestão administrativa executada pelo órgão responsável pela política habitacional federal (CARDOSO, 2013, p. 17-33).
} 
Na primeira etapa do $\mathrm{BNH}$, que tratava da questão habitacional como um problema de construção e oferecimento de unidades, destacam-se três objetivos: "necessidade de reativar a economia, gerar grande quantidade de empregos em áreas urbanas [...] e, finalmente, tornar viável o sistema financeiro de habitação gerido pelo BNH" (RZEZINSKI, SCHWEIZER, 1985). Essa etapa priorizou a produção quantitativa de unidades, mas no âmbito de desenvolvimento social e urbano provocou "deformações" que estimularam o redirecionamento da política habitacional. A segunda etapa, iniciada em 1974, foi marcada por programas que visavam a urbanização de favelas (PROMORAR) ${ }^{5}$ e o financiamento de lotes urbanizados (PROFILURB). A partir de 1984 (terceira etapa), são incorporados programas de autoconstrução, embora sejam mantidas as demais formas de financiamento e produção habitacional. A despeito da grande produção promovida pelo $\mathrm{BNH}$, a habitação continuou a ser considerada uma mercadoria para uma demanda solvável. Conforme Gabriel Bolaffi (1982, p. 47), o "problema da habitação popular [...] não passou de um artifício político formulado para enfrentar um problema econômico conjuntural".

Em 1986 o BNH, insolvente, foi encerrado, ficando a Caixa Econômica Federal como único gestor dos poucos recursos disponíveis.

Com o processo de democratização em curso no país, muitos municípios, com governos populares, passaram a desenvolver, com recursos próprios, iniciativas locais de promoção da habitação para população de baixa renda.

Com base nessas experiências e na ação dos movimentos sociais por moradia, articulados a entidades profissionais, sindicatos e meio acadêmico, foi apresentada ao processo constituinte, no bojo das emendas populares em 1987, a "Emenda Popular pela Reforma Urbana".

A Constituição Federal (CF), aprovada em 1988, incluiu o tema em seus artigos 182 e 183, que constituem o capítulo II da Política Urbana na Constituição Federal. Esse capítulo introduz o princípio da Função Social da Propriedade Urbana. Em 2000, a moradia é inserida como direito social na Constituição por meio da Emenda Constitucional no 26, ou seja, a habitação passa a ser um direito, como a saúde ou a educação. Em 2001, é aprovada a Lei 10.257/2001, conhecida como Estatuto da Cidade, que dispõe sobre diversos instrumentos legais que tratam do estabelecido pela Constituição: a função social da cidade e da propriedade urbana. Ampliando a preocupação com as questões referentes às cidades, como o acesso à moradia, ao saneamento e ao transporte, é criado, em 2003, o Ministério das

\footnotetext{
${ }^{5}$ PROMORAR - Programa de erradicação de sub-habitações, BNH. PROFILURB - Programa de Financiamento de lotes urbanizados, BNH.
} 
Cidades. No capítulo II do Estatuto da Cidade, são apresentados como instrumentos da política urbana: os planos de ordenação e desenvolvimento socioeconômico do território; o planejamento das regiões metropolitanas, aglomerações urbanas e microrregiões; e, na instância municipal, tem-se o zoneamento ambiental, o plano plurianual, as diretrizes orçamentárias, os planos, programas e projetos setoriais, os planos de desenvolvimento econômico e social e, com destaque, o plano diretor. Esse último, a partir de então, torna-se obrigatório para todas as cidades contidas em regiões metropolitanas ou que possuam mais de 20 mil habitantes.

Cabe ainda destacar que em 2015 foi aprovado o Estatuto da Metrópole, por meio da Lei Federal no 13.089, o qual estabelece que as regiões metropolitanas devem apresentar o plano de desenvolvimento urbano integrado. Esse instrumento deve ser aprovado por lei estadual e tem por objetivo apresentar diretrizes ${ }^{6}$ para o planejamento das regiões metropolitanas. Ressalta-se, no artigo 10 do Estatuto da Metrópole, que, a despeito da elaboração do plano de desenvolvimento urbano integrado, os municípios não estão isentos da elaboração de seus planos diretores, conforme estabelecido no Estatuto da Cidade. E ainda coloca-se que esses planos diretores devem estar em conformidade com esse plano integrado.

Em 2005, aprova-se o Sistema e Fundo Nacionais de Habitação de Interesse Social e, em 2007, o Plano de Aceleração do Crescimento (PAC), que trata de investimentos em infraestrutura, que associados a medidas econômicas, fomentam os setores produtivos, estimulando o desenvolvimento do país. Na sequência das políticas habitacionais, tem-se, em julho de 2009, o Plano Minha Casa Minha Vida (PMCMV) e, em dezembro de 2009, o Plano Nacional de Habitação.

O Programa Habitacional Minha Casa Minha Vida, aprovado através da Lei Federal no 11.977/2009, objetiva atender às necessidades habitacionais da população de baixa renda nas áreas urbanas. O Programa baseia-se na concessão de financiamentos com recursos do Orçamento Geral da União a beneficiários associados a uma entidade organizadora. Pode ocorrer ainda contrapartida por parte dos estados, municípios ou Distrito Federal.

\footnotetext{
${ }^{6}$ Conforme artigo 12 do Estatuto da Metrópole, o plano de desenvolvimento urbano integrado deve abranger áreas urbanas e rurais e apresentar no mínimo: "I - as diretrizes para as funções públicas de interesse comum, incluindo projetos estratégicos e ações prioritárias para investimentos; II - o macrozoneamento da unidade territorial urbana; III - as diretrizes quanto à articulação dos Municípios no parcelamento, uso e ocupação no solo urbano; IV - as diretrizes quanto à articulação intersetorial das políticas públicas afetas à unidade territorial urbana; V - a delimitação das áreas com restrições à urbanização visando à proteção do patrimônio ambiental ou cultural, bem como das áreas sujeitas a controle especial pelo risco de desastres naturais, se existirem; e VI o sistema de acompanhamento e controle de suas disposições" (art 12, § 10, Lei Federal 13.089/2015).
} 


\title{
Dispositivos Conflitantes
}

No art. 2 do Estatuto da Cidade, em que são expostas as diretrizes gerais da política urbana, destacam-se as proposições de gestão democrática para a elaboração dos instrumentos de governo voltados para o desenvolvimento urbano e de cooperação entre as diversas instâncias de governo e a iniciativa privada. É definido que à União cabe legislar sobre normas de direito urbanístico, sobre normas para cooperação entre União, Estados, Distrito Federal e Municípios, visando o equilíbrio do desenvolvimento urbano, além da promoção de programas habitacionais e de saneamento básico e da instituição de diretrizes para o desenvolvimento urbano. A elaboração e a execução de planos nacionais e regionais para ordenação do território também são definidas como competências da União tanto no Constituição Federal quanto no Estatuto da Cidade (BRASIL, 1988; BRASIL, 2001). As diretrizes propostas pelo Estatuto da Cidade encontram, por sua vez, um cenário urbano caracterizado na maioria das vezes por grande diversidade tanto intraurbana quanto metropolitana.

Além dessa diversidade de estruturas, que se refere tanto aos aspectos físicos e populacionais quanto administrativos, percebem-se descompassos entre a formulação de políticas públicas e suas implementações na própria esfera federal, como é o caso do Programa Minha Casa Minha Vida (PMCMV), cuja proposta se não contraria aquelas formulações, também não as reflete. Dessa forma, o PMCMV é aprovado antes do Plano Nacional de Habitação - já formulado naquele momento - com o objetivo claro de injetar capital no setor da construção civil em um momento de crise econômica.

\begin{abstract}
Ao publicitar o novo programa antes de apresentar o Plano Nacional de Habitação (PlanHab) - uma estratégia de longo prazo para equacionar o problema habitacional, que foi formulada e debatida por ano e meio, sob a coordenação da Secretaria Nacional de Habitação, que estava pronta para ser publicada em janeiro de 2009 -, o governo perdeu uma excelente oportunidade para mostrar como uma ação anticíclica poderia se articular com uma estratégia estrutural para atacar um problema brasileiro crônico, no âmbito de um projeto nacional de desenvolvimento com inclusão social. (BONDUKI, 2009, p. 1)
\end{abstract}

No Sistema Nacional de Habitação de Interesse Social (SNHIS), para obtenção dos recursos do fundo federal, são definidos como obrigação dos municípios a constituição de fundo, de conselho e a formulação de plano habitacional, que compõem os três eixos ${ }^{7}$. No

\footnotetext{
7 Os três eixos, aqui referidos, são definidos no Art. 12 da Lei Federal 11.124/05 que regulamenta o Sistema Nacional de Habitação de Interesse Social (SNHIS), nos incisos de I a III:

"I - constituir fundo, com dotação orçamentária própria, destinado a implementar Política de Habitação de Interesse Social e receber os recursos do FNHIS;
} 
entanto, o Programa Minha Casa Minha Vida, mesmo sendo aprovado quatro anos após o SNHIS, não menciona a obrigatoriedade de atender aos três eixos, uma vez que as regras do programa ${ }^{8}$, diferentemente do SNHIS, encaminham os recursos ao Fundo de Arrendamento Residencial (FAR), que é operacionalizado pela Caixa Econômica Federal (CEF). Dessa forma, a gestão democrática fica comprometida, pois o repasse do fundo ocorre sem o acompanhamento e a fiscalização do conselho municipal, que pode inclusive não existir.

Outra questão relevante é o fato do PMCMV não considerar o estudo das tipologias de municípios ${ }^{9}$ elaborado pelo Plano Nacional de Habitação (PlaNHab), que propicia o aprimoramento da leitura do déficit de habitação e do tipo específico de produto habitacional mais adequado para cada localidade. Deve-se considerar, ainda, que a produção da cidade (e de habitação) pressupõe terra e esta apresenta valor diferente em cada lugar. O PlanHab apresenta estudos das demandas de habitação a partir do cruzamento das informações de faixas de renda e tipologias de municípios, pois compreende-se que os produtos habitacionais deveriam ser oferecidos de forma diferenciada. Portanto, o fato do PMCMV não considerar as tipologias de municípios do PlanHab faz com que todos recebam os mesmos benefícios. Esse estudo das tipologias constituiria uma importante ferramenta na descentralização da política e aplicação de recursos no SNHIS.

A produção de habitação e, portanto, das cidades, que implica a produção de espaços públicos como postos, creches, escolas, praças etc., ocorre sem um plano prévio para ordenar a ocupação do território. Mesmo quando existe um PLHIS (Plano Local de Habitação de Interesse Social) ou planos de outras instâncias de governo, a produção habitacional, a partir do PMCMV, que tem seus recursos operacionalizados pela CAIXA, ocorre majoritariamente por empresas privadas, que visam o lucro. Portanto, a lógica de ocupação territorial é a do mercado, e não conforme o estabelecido pelos planos habitacionais. Dentro dessa lógica, o subsídio, por exemplo, fornecido pelo PMCMV, criado a princípio para

II - constituir conselho que contemple a participação de entidades públicas e privadas, bem como de segmentos da sociedade ligados à área de habitação, garantido o princípio democrático de escolha de seus representantes e a proporção de $1 / 4$ (um quarto) das vagas aos representantes dos movimentos populares;

III - apresentar Plano Habitacional de Interesse Social, considerando as especificidades do local e da demanda $[\ldots]^{\prime \prime}$.

${ }^{8}$ Consultar a Lei Federal que aprova o Programa Minha Casa Minha Vida I: $11.977 / 2009$ e MCMV II: $12.424 / 2011$.

${ }^{9} \mathrm{O}$ estudo das tipologias de municípios é uma adequação do trabalho elaborado pelo Observatório das Metrópoles para o Ministério das Cidades em 2005. Esta metodologia de classificar os municípios brasileiros em tipologias utiliza diversos indicadores como número de habitantes, importância metropolitana, polarização regional, variáveis socioeconômicas, níveis de pobreza e de urbanização e desenvolvimento urbano, dentre outros. (Fonte: PlanHab, 2009, p. 15). O PlanHab desenvolveu 11 categorias de municípios, enquanto o MCMV considera apenas três. 
possibilitar o acesso às classes mais baixas, eleva o preço do imóvel e acaba por não beneficiar essa população.

O descompasso entre o Programa Minha Casa Minha Vida e Plano Nacional de Habitação pode ser compreendido a partir do contexto em que o Programa foi aprovado, ou seja, como um projeto econômico do governo frente à crise de 2008, que teve origem nos Estados Unidos e repercutiu em todo o mercado financeiro globalizado. Para Cardoso (2013, p. 35), o "[...] Programa busca claramente impactar a economia através dos efeitos multiplicadores gerados pela indústria da construção." Repete-se dessa forma, o que ocorreu no BNH, onde a questão habitacional, segundo Gabriel Bolaffi (1982), foi "um falso problema" 10 para justificar as estratégias de poder, dos negócios e das ideologias dominantes.

\subsection{Metropolização e Habitação de Interesse Social | A Região Metropolitana de Campinas}

Cabe ressaltar que, enquanto nos países desenvolvidos, a partir da Revolução Industrial, o processo de urbanização ocorre de forma lenta, nos países em desenvolvimento, sua transformação de países predominantemente rurais em altamente urbanizados é um acontecimento marcante na história apenas no século XX. O Brasil, parte desse grupo, urbaniza-se tardiamente e experimenta um crescimento acelerado desse processo de urbanização a partir dos anos 1950, principalmente devido ao crescimento industrial e ao êxodo rural.

Com a aceleração da urbanização nas décadas de 60 e 70 e o crescimento expressivo das grandes cidades, outro fenômeno urbano ainda mais complexo começou a se delinear no cenário nacional: a metropolização, com a conformação de sistemas econômicos e urbanos complexos, resultantes de um processo plural decorrente da alta densidade demográfica, do adensamento das funções urbanas e da integração de infra-estruturas física e econômica, conformando um padrão específico de ocupação do solo em determinado espaço social e historicamente construído (ALVES, 2007, p. 1).

Campinas e sua região de governo consolidam-se em 1970 como o mais importante polo industrial do interior (NEGRI, 1996). A ampliação e a modernização da agricultura

\footnotetext{
${ }^{10}$ Quando Gabriel Bolaffi (1982, p. 40) utiliza, em seu texto, a expressão "falso problema", referindo-se não apenas à habitação, mas a diversos problemas urbanos, não quer dizer que esses problemas não existam, mas que eles "têm sido formulados falsamente; formulados não a partir das características intrínsecas ao problema, mas a partir das necessidades da estratégia do poder e das ideologias que foram elaboradas durante os últimos quinze ou vinte anos".
} 
resultam em um processo de grande expansão urbana, com intensa conurbação, destacando-se a via Anhanguera ${ }^{11}$ como principal eixo condutor desse processo. Em 1975, as geógrafas Fany Davidovich e Olga Buarque de Lima definem o termo "Área de Campinas" como uma aglomeração submetropolitana que engloba os municípios de Valinhos, Vinhedo, Sumaré e Nova Odessa no eixo da rodovia Anhanguera; Paulínia e Indaiatuba no eixo da rodovia Santos Dumont; e Campinas, no entroncamento dos dois eixos. Para a definição da área de Campinas, é analisada a permeabilidade entre municípios, identificando aglomerações urbanas sujeitas a apresentar problemas econômicos e sociais semelhantes (FONSECA; DAVANZO; NEGREIROS, 2002). Semeghini (1991) observa que a área de influência de Campinas era mais ampla do que a dos seis municípios citados, mas que estes se destacavam pela intensa conurbação e fluxos intraurbanos. Nos anos 1980, o processo de expansão urbana do município de Campinas seguia a "lógica regional de localização", ou seja, diversos loteamentos são implantados em áreas distantes do tecido urbano constituído anteriormente, no entanto, próximo às rodovias (SILVA, 2008).

Nos anos 1980 e 1990, tanto o município de Campinas quanto os municípios vizinhos aumentam sua participação na indústria nacional, constituindo um dos maiores centros manufatureiros do país. Em 1999, um estudo para atualizar os estudos de rede urbana realizado pelo IPEA, com a participação do IBGE e de outros centros de pesquisa, identifica Campinas como metrópole regional. Campinas apresenta, nessa época, uma área muito maior do que a identificada, em 1975, como "Área de Campinas". Assim, é aprovada oficialmente em 2000, por meio da Lei Complementar Estadual no 870, a Região Metropolitana de Campinas (RMC).

A RMC é uma das cinco regiões metropolitanas ${ }^{12}$ do estado de São Paulo ${ }^{13}$, sendo que o fato de Campinas se transformar em metrópole expressa a sua importante participação no espaço econômico e social desse estado. A RMC localiza-se em uma posição geográfica estratégica, permeada por uma malha viária densa e de boa qualidade (Mapa 1, p. 27), que

\footnotetext{
${ }^{11}$ A rodovia Anhanguera é inaugurada em 1948.

${ }^{12}$ As cinco regiões metropolitanas do estado de São Paulo são: a Região Metropolitana do Estado de São Paulo (Lei Complementar Federal no 14/1973), a Região Metropolitana da Baixada Santista (LC Estadual no 815/1996), a RMC (LC Estadual no 870/2000), a Região Metropolitana do Vale do Paraíba (LC Estadual 1.166/2012) e a Região Metropolitana de Sorocaba (LC Estadual n 1271/2014).

${ }^{13}$ Estudos apontam para o processo de formação da megalópole do Sudeste do Brasil. Conforme ressaltam Queiroga e Benfatti (2007), a megalópole deve ser compreendida não como megacidade ou grande metrópole, mas como uma rede urbana densa, que conecta de forma complexa diversas formas urbanas (cidades, distritos, metrópoles), apresentando conurbação funcional e não obrigatoriamente física, embora seja recorrente em algumas áreas das megalópoles. A megalopolização do Sudeste, que inclui desde o eixo "Rio-São Paulo", parte do sul de Minas (de Juiz de Fora a Poços de Caldas), estendendo-se pelas mais importantes rodovias paulistas que conectam São Paulo e Campinas a Ribeirão Preto, a São Carlos, a Sorocaba, a São José dos Campos, considerando apenas os principais centros regionais integrados no processo. Para os autores, é essencial para o estudo da dinâmica e estrutura metropolitana da região de Campinas a sua inserção megalopolitana.
} 
articula o interior do estado com as outras regiões metropolitanas de São Paulo e da Baixada Santista e com o sul e sudoeste mineiro.

Mapa 1 - A Região Metropolitana de Campinas | mancha urbana e as principais rodovias

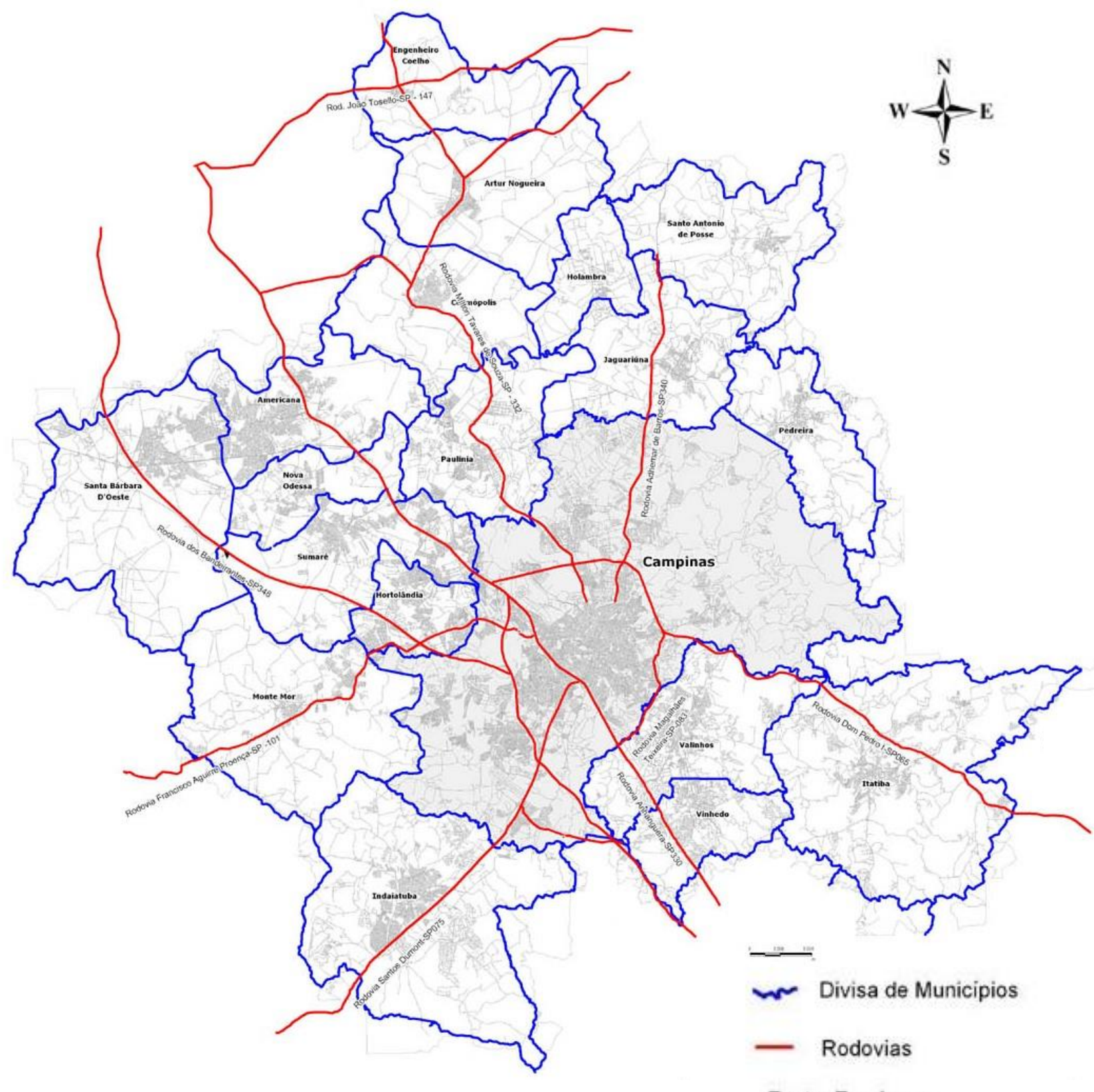

Fonte: Emplasa

Fonte: Mapa do Plano Diretor de 2006 de Campinas - SEPLAMA (Secretaria de Planejamento, Desenvolvimento Urbano e Meio Ambiente). 
A RMC faz parte do chamado "Complexo Metropolitano Expandido" também conhecida como Megalópole do Sudeste Brasileiro (QUEIROGA; BENFATTI, 2007), que ultrapassa 29 milhões de habitantes e configura aproximadamente 75 por cento da população do estado.

A RMC abrange cerca de 2,8 milhões de habitantes em 2010, conforme o censo do IBGE, e tem sua população estimada em 2013 em mais de 3 milhões de habitantes ${ }^{14}$ (ver Tabela 1 com as populações de cada município, p. 32), sendo constituída por 19 municípios paulistas: Americana, Artur Nogueira, Campinas, Cosmópolis, Engenheiro Coelho, Holambra, Hortolândia, Indaiatuba, Itatiba, Jaguariúna, Monte Mor, Nova Odessa, Paulínia, Pedreira, Santa Bárbara D'Oeste, Santo Antônio de Posse, Sumaré, Valinhos e Vinhedo. Para fiscalizar a execução das leis da região metropolitana e estabelecer metas de interesse comum, é criada em 2003 a Agência Metropolitana de Campinas, AGEMCamp ${ }^{15}$, com sede no município de Campinas. Em 2014, por meio da Lei n 1.532, o município de Morungaba foi adicionado, totalizando 20 municípios na RMC.

A maioria dos municípios da RMC desenvolveu-se a partir da rodovia Anhanguera, e parte deles encontra-se conurbada. Alguns municípios conectam-se a Campinas por meio da rodovia Zeferino Vaz, como Paulínia, Cosmópolis e Artur Nogueira, e outros, por meio da rodovia Adhemar de Barros, conforme se pode observar no Mapa 1 (p. 27).

Ressalta-se aqui a importância de que algumas questões sejam discutidas, pensadas e formuladas no âmbito metropolitano, pois temas como gestão da água, habitação e transportes transcendem os limites administrativos municipais. Laura Bueno e Cymbalista $(2007, \text { p. } 13)^{16}$ destacam que "[...] a economia política no território não tem fronteiras, como tem as jurisdições administrativas e normativas. Por isso o conhecimento dos aspectos regionais e setoriais é importante".

Os próprios planos diretores deveriam ser discutidos nas Câmaras Temáticas da RMC:

Por isso, e tendo em vista o intrínseco e complexo processo de conurbação que caracteriza grande parte das cidades da região, a interdependência econômica e sociocultural entre tais municípios e o grande deslocamento populacional diário existente, acredita-se não ser mais possível a elaboração

\footnotetext{
${ }^{14}$ Cabe lembrar que Morungaba é incluída na RMC apenas em 2014, portanto, não foi considerada nos totais de 2010 e 2013. No entanto, na Tabela 1 é apresentada a população do município para percepção das diferentes escalas municipais.

${ }^{15}$ A AGEMCamp (Agência Metropolitana de Campinas) é uma autarquia estadual instituída por meio da Lei Complementar no 946 de 2003.

${ }^{16} \mathrm{O}$ texto de Bueno e Cymbalista (2007) é resultado das discussões sobre condições e leis, principalmente o plano diretor, para a redistribuição da riqueza urbana e para que o Estado se dedique ao interesse público, "combatendo o patrimonialismo".
} 
de planos diretores que levem "apenas" em consideração os problemas de sua própria cidade, os horizontes na elaboração e implementação de um plano diretor devem ir além dos limites de seu município (BUENO; CYMBALISTA, 2007, p. 93, grifo nosso).

Por meio da AGEMCamp, é elaborado e aprovado em 2010 o Plano Metropolitano de Habitação de Interesse Social da Região Metropolitana de Campinas. Esse plano deveria refletir os problemas habitacionais comuns à região, sendo elaborado a partir de questões referentes à expansão metropolitana, como fluxos pendulares, a disponibilidade de terras, a diversidade de corpo técnico e administrativo dos municípios, os recursos financeiros, além das questões territoriais, como a continuidade da mancha urbana, com gestões diversas. Entretanto, o plano elaborado não parece refletir o pensamento metropolitano, pois os interesses de alguns municípios prevalecem sobre os de outros. O que não pode ser aleatório, uma vez que as reuniões das Câmaras Temáticas de Habitação promovidas pela AGEMCamp no processo de desenvolvimento do plano metropolitano não contaram com a participação de todos os municípios ${ }^{17}$, sendo recorrente a presença de representantes de um grupo específico de municípios.

Percebe-se que o Plano Metropolitano de Habitação de Campinas não difere muito daquilo que Villaça (1999 e 2005) e Maricato (2011c) discutem que ocorre com os planos diretores ao configurar-se como a representação dos interesses no espaço urbano de uma classe dominante. Da mesma forma que em planos diretores municipais algumas áreas são privilegiadas em detrimento de outras não aleatoriamente, mas em função de ser resultado de luta de forças, também em planos metropolitanos alguns municípios e/ou regiões têm tratamento diferenciado.

O Plano Metropolitano (2010, p. 211) coloca como princípio "definir prioridades e metas de ação, considerando as necessidades e características dos municípios da RMC, a partir do agrupamento dos mesmos [...]". Reforçando essas características, o Plano estabelece estratégias de ocupação territorial em concordância com o estabelecido pelos Planos Diretores Municipais, ou seja, priorizam-se os planos municipais no próprio Plano Metropolitano. Parece-nos que a "tradição municipalista" de origem colonial, discutida por Maricato, prevalece mesmo quando há o esforço de um plano metropolitano, pois "recuperada pela Constituição de 1977, reafirmada pelas políticas paroquiais e clientelistas

\footnotetext{
${ }^{17}$ Essa informação é baseada nas Memórias de Reuniões das Câmaras Temáticas de Habitação, ocorridas entre outubro de 2008 e maio de 2009 para discussão do Plano Metropolitano de Habitação de Interesse Social da Região Metropolitana de Campinas. Considerando os 19 municípios que compõem a RMC, a média de representantes municipais presentes nessas reuniões foi de 8,75 municípios.
} 
exercidas pelos executivos e legislativos, reforça esse localismo que foi incentivado ainda durante os anos 1990, pelo Banco Mundial e congêneres" (MARICATO, 2011b, p. 18).

Se algumas temáticas possibilitam uma discussão municipal ou em diferentes instâncias de governo, em relação à expansão territorial e aos problemas decorrentes dela, fica explícita a necessidade de uma discussão mais ampla. No entanto, no Plano Metropolitano de Habitação de Campinas essa abordagem parece frágil. Mais do que isso, não há a compreensão de que se trata de outra lógica de ocupação territorial, onde a dispersão urbana, por exemplo, deveria ser compreendida e refletida no Plano, e não simplesmente negada, visto que os municípios não crescem a partir de lógicas individuais no sentido centro-periferia até atingir os limites municipais, corroborando o processo de conurbação. Há lógicas de expansão urbana que transcendem os limites administrativos dos municípios e que deveriam estar discutidas no Plano Metropolitano. A não compreensão dessa lógica está explicitada em um dos princípios do Plano:

Estabelecer uma estratégia de ocupação territorial para a Região Metropolitana de Campinas, em acordo com os Planos Diretores Municipais, visando inibir a permanente expansão da fronteira urbana e 0 surgimento de problemas relativos à extensão de infra-estrutura básica, sistema viário e de transportes, bem como de equipamentos e áreas verdes e de lazer (PLANO METROPOLITANO, 2010, p. 210, grifo nosso).

Para Reis (2006), em seu estudo sobre os processos de dispersão urbana no Brasil, o "foco de interesse" deixa de ser o centro tradicional e passa a ser "[...] o sistema de vias, que dá acesso a várias regiões" (p. 89), uma vez que a urbanização ocorre onde há infraestrutura, e não existem mais as tradicionais divisões entre zona urbana, suburbana e zona rural. Segundo o autor, "A cidade tradicional, de tecido contínuo, com limites razoavelmente definidos, já não é a regra. A cidade não morreu, nem desapareceu. Ela convive e se relaciona com um número cada vez maior de áreas dispersas [...]" (p. 80-81). A dispersão urbana é consequência da descentralização industrial e da crescente mobilidade da população. A esse respeito, Villaça (2001) coloca que a segregação domina o processo de estruturação espacial. As áreas não homogêneas dispersas organizam-se de acordo com seus diferentes usos. Dessa forma, as ocupações industriais situam-se ao longo dos eixos rodoviários, ou próximas a eles, enquanto que as áreas residenciais localizam-se próximas aos principais entroncamentos rodoviários ou em suas margens.

Os conjuntos habitacionais populares parecem refletir a lógica de ocupação dispersa no território dos condomínios, dos shoppings e de outros grandes empreendimentos fechados. Embora as razões de suas implantações não sejam as mesmas, estes seguem a "lógica das rodovias" enquanto aqueles ocupam as áreas desprezadas pelo mercado 
imobiliário. No conjunto da cidade, resultam em problemas urbanos e questões de deslocamento semelhantes, pois parecem configurar a mesma morfologia urbana. Tais processos deveriam ser analisados em maior profundidade, para que a elaboração das políticas públicas e o planejamento urbano pudessem corresponder às questões contemporâneas de expansão urbana.

\subsubsection{Dados da Região Metropolitana de Campinas}

A Região Metropolitana de Campinas é formada por municípios bastante díspares, tanto em relação à escala quanto às suas configurações, a questões históricas, ao PIB e a tipos de serviços.

Para a discussão dos próximos capítulos, as legislações municipais, assim como a expansão dos conjuntos de habitação de interesse social, são fundamentais para a compreensão dessa diversidade de municípios, pois, a despeito de serem realizados quadros comparativos entre os municípios, num esforço metodológico de discutir questões, não se pretende perder a especificidade de cada um deles. Alguns dados são perceptíveis por meio de tratamento estatístico e outras questões são mais subjetivas.

Dessa forma, relacionam-se aqui os principais $\operatorname{dados}^{18}$ em forma de tabelas e de infográficos específicos, cuja elaboração visou a associação das informações ao território. Quanto às questões subjetivas, elas estão presentes no texto de análise dos planos, permeando a leitura dos instrumentos. Na Tabela 1 (p. 32), apresentam-se os dados referentes às populações e densidades demográficas e pode-se observar a diversidade de escala desses municípios.

A partir da Tabela 1, criou-se o mapa a seguir, de modo que as cidades e suas escalas pudessem ser visualizadas juntamente com a estrutura rodoviária e a proximidade de outros municípios. A classificação dos municípios em muito pequenos, pequenos, médios, grandes e macro não segue a denominação do IBGE ou de qualquer outro instituto, foi desenvolvida aqui, a partir dos dados populacionais da Tabela 1, apenas para a leitura dessa região metropolitana.

\footnotetext{
${ }^{18}$ É importante notar que as Tabelas de 1 a 5 (p. 32 a 37) retratam os dados dos municípios da RMC de 2000 e de 2010. Como o objetivo dessas tabelas é a caracterização desses municípios, mesmo que em 2010 Morungaba não fizesse parte da Região Metropolitana de Campinas, ele foi incluído nas tabelas de dados.
} 
Tabela 1 - População (urbana e rural), área e densidade demográfica | os municípios da $\underline{\mathrm{RMC}}$

\begin{tabular}{|l|r|r|r|r|r|}
\hline $\begin{array}{c}\text { Municípios } \\
\text { da RMC }\end{array}$ & $\begin{array}{c}\text { População } \\
\text { total } \\
(\mathrm{em} 2010)\end{array}$ & $\begin{array}{c}\text { População } \\
\text { urbana } \\
(\mathrm{em} \mathrm{2010)}\end{array}$ & $\begin{array}{c}\text { População } \\
\text { rural } \\
(\mathrm{em} 2010)\end{array}$ & \multicolumn{1}{c|}{$\begin{array}{c}\text { Área } \\
\left(\mathrm{km}^{2}\right)\end{array}$} & $\begin{array}{c}\text { Densidade } \\
\text { demográfica } \\
\left(\mathrm{hab} / \mathrm{km}^{2}\right)\end{array}$ \\
\hline Americana & 210.638 & 209.654 & 984 & 133,93 & $1.572,75$ \\
\hline Artur Nogueira & 44.177 & 39.998 & 4.179 & 178,03 & 248,15 \\
\hline Campinas & 1.080 .113 & 1.061 .540 & 18.573 & 794,43 & $1.359,60$ \\
\hline Cosmópolis & 58.827 & 54.634 & 4.193 & 154,66 & 380,37 \\
\hline Eng. Coelho & 15.721 & 11.498 & 4.223 & 109,94 & 142,99 \\
\hline Holambra & 11.299 & 8.184 & 3.115 & 65,58 & 172,30 \\
\hline Hortolândia & 192.692 & 192.692 & - & 62,28 & $3.094,16$ \\
\hline Indaiatuba & 201.619 & 199.592 & 2.027 & 312,05 & 646,11 \\
\hline Itatiba & 101.471 & 85.666 & 15.805 & 322,23 & 314,90 \\
\hline Jaguariúna & 44.311 & 43.033 & 1.278 & 141,40 & 313,37 \\
\hline Monte Mor & 48.949 & 45.978 & 2.971 & 240,41 & 203,61 \\
\hline Morungaba & 11.769 & 10.051 & 1.718 & 146,753 & 80,20 \\
\hline Nova Odessa & 51.242 & 50.407 & 835 & 74,32 & 689,48 \\
\hline Paulínia & 82.146 & 82.070 & 76 & 138,72 & 592,17 \\
\hline Pedreira & 41.558 & 41.209 & 349 & 108,59 & 382,70 \\
\hline $\begin{array}{l}\text { Santa Bárbara } \\
\text { d'Oeste }\end{array}$ & 180.009 & 178.596 & 1.413 & 270,90 & 664,49 \\
\hline $\begin{array}{l}\text { Santo A. de } \\
\text { Posse }\end{array}$ & 20.650 & 18.834 & 1.816 & 154,00 & 134,09 \\
\hline Sumaré & 241.311 & 238.470 & 2.841 & 153,50 & $1.572,04$ \\
\hline Valinhos & 106.793 & 101.626 & 5.167 & 148,59 & 718,70 \\
\hline Vinhedo & 63.611 & 61.612 & 1.999 & 81,60 & 779,51 \\
\hline RMC & 2.797 .137 & 2.725 .293 & 71.844 & $3.644,9$ & 767,40 \\
\hline Estado de SP & 41.262 .199 & 39.585 .251 & 1.676 .948 & $248.222,80$ & 166,23 \\
\hline
\end{tabular}

Fonte das Informações: tabela sistematizada pela autora a partir de informações do Censo Demográfico de 2010 e da estimativa populacional para 2013, conforme o IBGE (Instituto Brasileiro de Geografia e Estatística).

Pretende-se perceber, a partir da Tabela 1 (p. 32) e do Mapa 2 (p. 33), as diferentes escalas dos municípios, pois se acredita que isso reflita na sua estrutura políticoadministrativa e, portanto, nos planos diretores que serão aqui analisados. Ressalta-se que a intenção não é compreender qual a discussão do plano diretor ou a forma como o mesmo foi elaborado, mas delimitar quais instrumentos urbanísticos voltados à habitação são incluídos nos planos diretores municipais da Região Metropolitana de Campinas. 


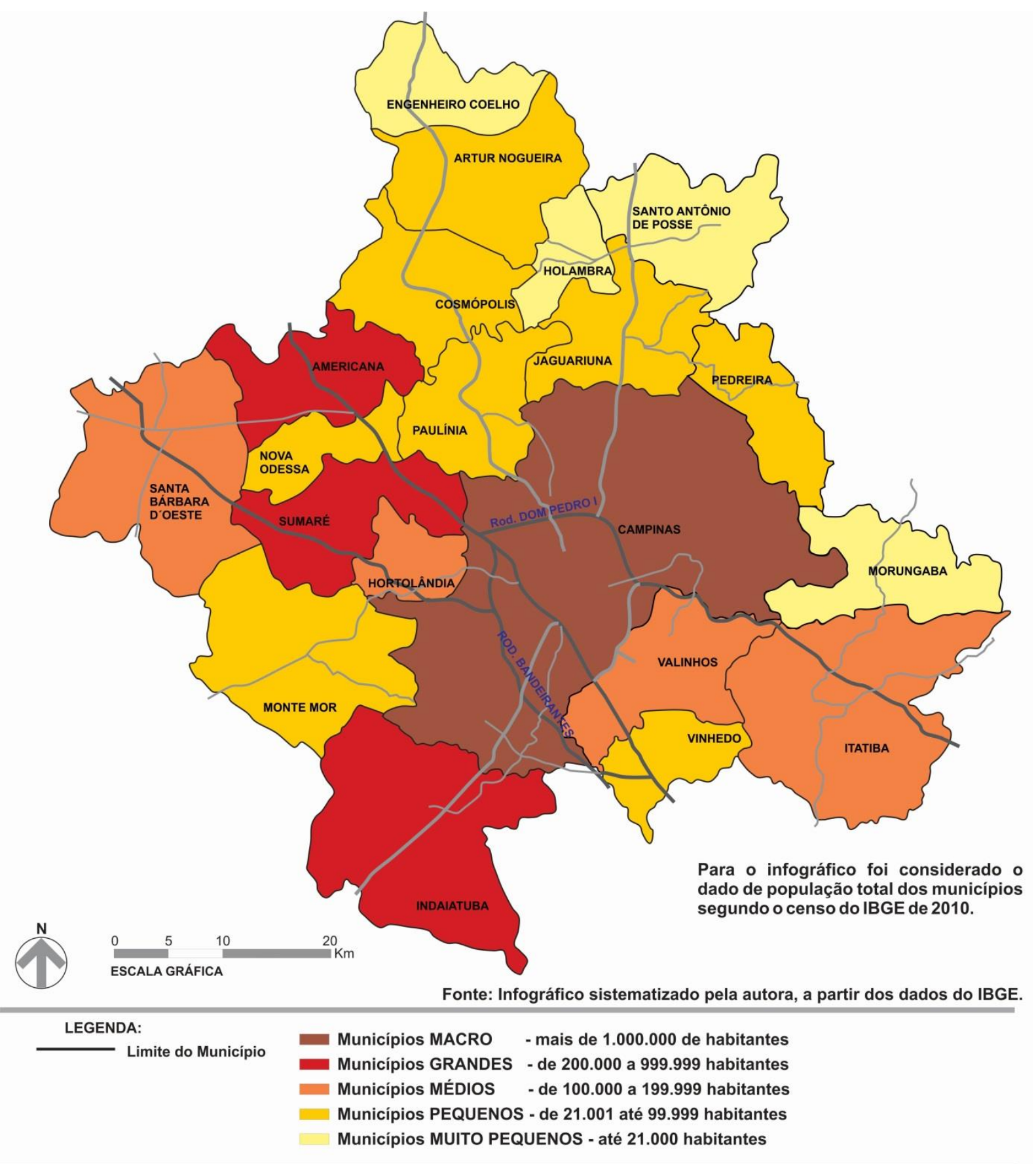

Fonte do mapa: elaborado pela autora a partir dos dados do IBGE.

A seguir, a Tabela 2 apresenta os valores referentes ao Produto Interno Bruto (PIB) dos vinte municípios da Região Metropolitana de Campinas, e de forma destacada na cor vermelha, os municípios que apresentaram valores acima da média da região. 
Tabela 2 - PIB dos municípios da RMC em 2010

\begin{tabular}{|l|r|r|r|}
\hline \multicolumn{1}{|c|}{ Localidades } & $\begin{array}{r}\text { PIB } \\
\text { (Em milhões de } \\
\text { reais correntes) }\end{array}$ & $\begin{array}{c}\text { PIB per Capita } \\
\text { (Em reais correntes) }\end{array}$ & $\begin{array}{c}\text { Participação no PIB } \\
\text { do Estado (Em \%) }\end{array}$ \\
\hline Americana & $6.659,25$ & $31.652,38$ & 0,534 \\
\hline Artur Nogueira & 540,94 & $12.274,27$ & 0,043 \\
\hline Campinas & $36.712,72$ & $34.020,35$ & 2,943 \\
\hline Cosmópolis & $1.006,66$ & $17.152,46$ & 0,081 \\
\hline Engenheiro Coelho & 239,04 & $15.262,29$ & 0,019 \\
\hline Holambra & 515,29 & $45.775,52$ & 0,041 \\
\hline Hortolândia & $6.228,38$ & $32.386,00$ & 0,499 \\
\hline Indaiatuba & $5.833,22$ & $29.008,18$ & 0,468 \\
\hline Itatiba & $3.419,44$ & $33.761,23$ & 0,274 \\
\hline Jaguariúna & $3.066,65$ & $69.440,98$ & 0,246 \\
\hline Monte Mor & $1.193,07$ & $24.428,59$ & 0,096 \\
\hline Morungaba & 329,06 & $28.000,29$ & 0,026 \\
\hline Nova Odessa & $1.959,63$ & $38.305,46$ & 0,157 \\
\hline Paulínia & $8.115,39$ & $99.179,87$ & 0,650 \\
\hline Pedreira & 694,64 & $16.737,91$ & 0,056 \\
\hline $\begin{array}{l}\text { Santa Bárbara } \\
\text { d'Oeste }\end{array}$ & $3.789,95$ & $21.064,18$ & 0,304 \\
\hline Santo Antônio de & 387,23 & $18.771,97$ & 0,031 \\
\hline Posse & $7.848,92$ & $32.581,53$ & 0,629 \\
\hline Sumaré & $3.586,40$ & $33.653,28$ & 0,287 \\
\hline Valinhos & $6.718,83$ & $105.886,76$ & $\mathbf{0 , 3 9 6}$ \\
\hline Vinhedo & $\mathbf{4 . 9 4 2 , 2 4}$ & $\mathbf{3 6 . 9 6 7 , 1 8}$ & \\
\hline Média & & & 0.539 \\
\hline
\end{tabular}

Fonte: dados sistematizados pela autora a partir do Censo do IBGE de 2010.

O PIB, que reflete a atividade econômica da região, demonstra a importância da Região Metropolitana de Campinas. Também fica evidente a diversidade do perfil econômico dos municípios que a compõem. Destaca-se, na Tabela 2, os municípios de Campinas, Paulínia, Sumaré, Vinhedo, Americana, Hortolândia e Indaiatuba com PIBs acima da média da região em 2010, lembrando que esse valor trata da soma dos bens e serviços finais produzidos. Pode-se observar, também, a importância desses municípios a partir da sua participação no PIB do Estado de São Paulo.

Observa-se que, em relação ao PIB per capita, ou seja, o PIB dividido pelo número de habitantes, apresentam-se como destaque os municípios de Vinhedo, Paulínia, Jaguariúna e Holambra. No entanto, cabe lembrar que o PIB pode ser alto, por se referir ao produto, mas ele não reflete necessariamente a renda dos munícipes. 
Para abordar a questão da distribuição de renda, considera-se o Índice de Gini, o qual varia de 0 a 1 , sendo que quanto mais próximo de 0 melhor é a distribuição de renda. 0 Índice trata da renda domiciliar per capita (considerando os domicílios particulares permanentes, conforme o IBGE).

Tabela 3 - Índice de Gini dos municípios da Região Metropolitana de Campinas

\begin{tabular}{|l|r|r|}
\hline \multicolumn{1}{|c|}{ Cidade } & $\mathbf{2 0 0 0}$ & \multicolumn{1}{c|}{$\mathbf{2 0 1 0}$} \\
\hline Americana & 0,4972 & 0,4693 \\
\hline Artur Nogueira & 0,5036 & 0,4709 \\
\hline Campinas & 0,5861 & 0,5782 \\
\hline Cosmópolis & 0,4969 & 0,4586 \\
\hline Engenheiro Coelho & 0,5152 & 0,4589 \\
\hline Holambra & 0,5649 & 0,5471 \\
\hline Hortolândia & 0,4670 & 0,4251 \\
\hline Indaiatuba & 0,5558 & 0,4865 \\
\hline Itatiba & 0,5261 & 0,4965 \\
\hline Jaguariúna & 0,5449 & 0,5020 \\
\hline Monte Mor & 0,5174 & 0,4557 \\
\hline Morungaba & 0,5054 & 0,4503 \\
\hline Nova Odessa & 0,4570 & 0,4236 \\
\hline Paulínia & 0,5734 & 0,4880 \\
\hline Pedreira & 0,4671 & 0,4261 \\
\hline Santa Bárbara d'Oeste & 0,4470 & 0,4188 \\
\hline Santo Antônio de Posse & 0,5478 & 0,4586 \\
\hline Sumaré & 0,4731 & 0,4737 \\
\hline Valinhos & 0,5417 & 0,5529 \\
\hline Vinhedo & 0,5560 & 0,5448 \\
\hline Média & $\mathbf{0 , 5 1 7 2}$ & $\mathbf{0 , 4 7 9 3}$ \\
\hline
\end{tabular}

Fonte: dados sistematizados pela autora a partir do Censo do IBGE de 2010.

A Tabela 3 apresenta o Índice de Gini dos municípios da Região Metropolitana de Campinas e podem-se perceber em destaque (na coluna de 2010) os municípios com melhor distribuição de renda, ou seja, aqueles que apresentaram valores abaixo da média: Americana, Artur Nogueira, Cosmópolis, Engenheiro Coelho, Hortolândia, Monte Mor, Morungaba, Nova Odessa, Pedreira, Santa Bárbara d'Oeste, Santo Antônio de Posse e Sumaré. É interessante observar que, entre esses municípios que apresentam uma melhor distribuição da riqueza, nenhum deles apresentou-se com um PIB per capita acima da média. Em relação ao total do PIB em 2010, entre esses municípios, apenas Americana e Hortolândia apresentaram valores mais altos. A partir dos dados de PIB e do Índice de Gini, pode-se então perceber que nos municípios da Região Metropolitana de Campinas que apresentam maiores riquezas, estas estão concentradas em uma minoria da população. 
Outro dado importante para se compreender as características da RMC são as faixas de rendimento nos municípios.

Tabela 4 - Municípios da RMC por faixas de rendimento

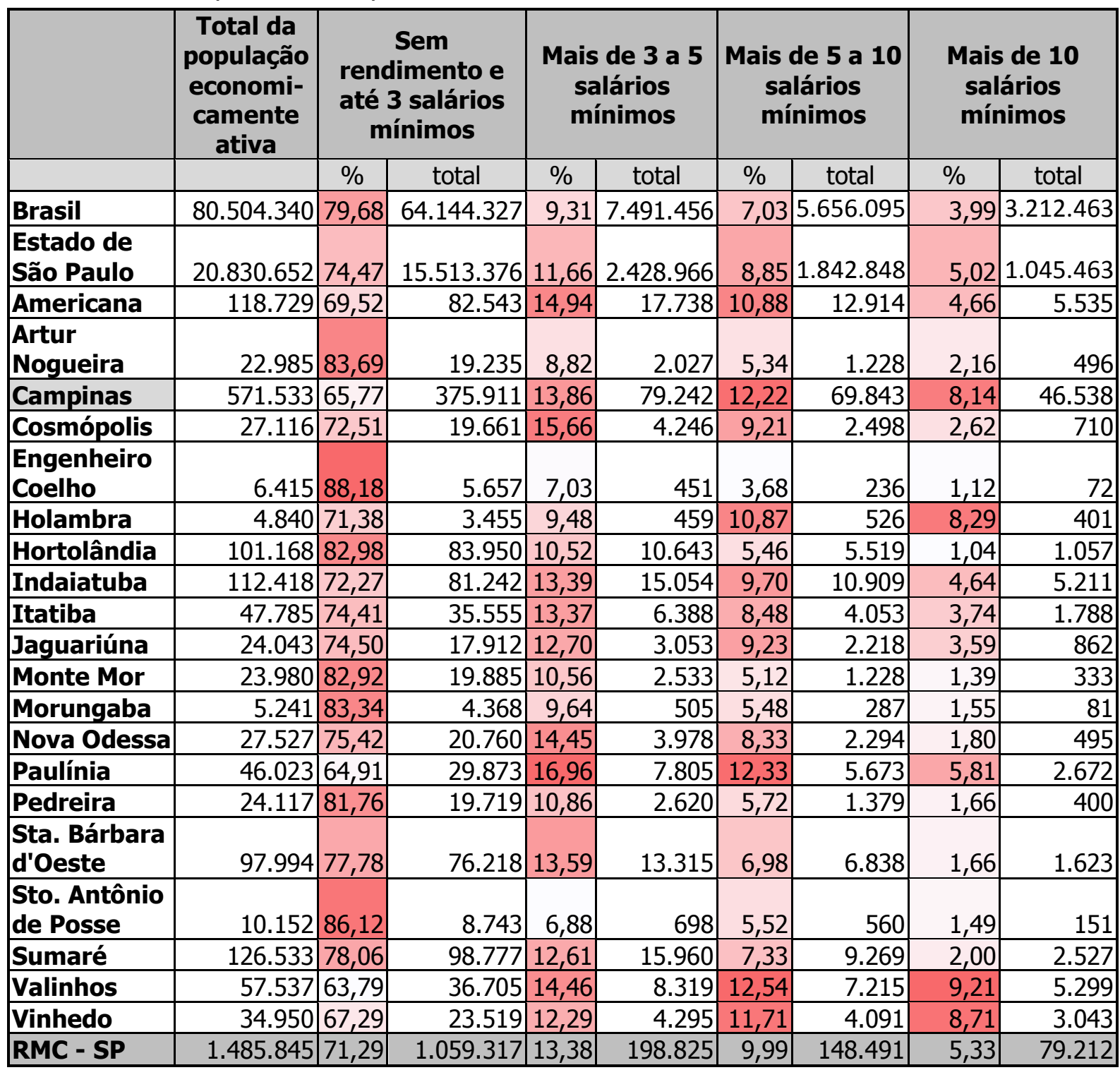

Fonte: dados sistematizados pela autora a partir do Censo do IBGE de 2010.

$\mathrm{Na}$ Tabela 4, podem-se perceber semelhanças com a tabela de PIB, pois os municípios que apresentam maiores percentuais na faixa acima de 10 salários mínimos (SM) são Valinhos, Holambra, Vinhedo, Campinas e Paulínia. Observam-se na faixa oposta, sem rendimento ou com rendimento até $3 \mathrm{SM}$, com maiores percentuais, os municípios de: Engenheiro Coelho, Santo Antônio de Posse, Morungaba, Artur Nogueira, Hortolândia, Monte Mor e Pedreira. Cabe lembrar que, para a Tabela 4 (p. 36), foi considerada a população economicamente ativa; com 10 anos ou mais de idade e na categoria sem rendimento foram 
incluídas as pessoas que recebiam somente em benefícios (o valor do SM considerado foi de $\mathrm{R} \$ 510,00)$.

Para finalizar, apresenta-se, na Tabela 5, o Valor Adicionado por tipo de atividade, de modo que se possa perceber as principais atividades econômicas de cada município. $\mathrm{Na}$ Tabela, estão na cor verde mais escura os maiores percentuais em cada atividade.

Tabela 5 - Percentual do Valor Adicionado Total por setor de atividade - municípios da RMC

\begin{tabular}{|l|r|r|r|r|}
\hline Localidades & $\begin{array}{c}\text { Participação da } \\
\text { Administração } \\
\text { Pública no Total } \\
\text { do Valor } \\
\text { Adicionado } \\
\text { (em \%) }\end{array}$ & $\begin{array}{c}\text { Participação da } \\
\text { Indústria no } \\
\text { Total do Valor } \\
\text { Adicionado } \\
\text { (em \%) }\end{array}$ & $\begin{array}{c}\text { Participação dos } \\
\text { Serviços no } \\
\text { Total do Valor } \\
\text { Adicionado } \\
\text { (em \%) }\end{array}$ & $\begin{array}{c}\text { Participação da } \\
\text { Agropecuária no } \\
\text { Total do Valor } \\
\text { Adicionado } \\
\text { (em \%) }\end{array}$ \\
\hline Americana & 8,32 & 36,86 & 54,72 & 0,10 \\
\hline Artur Nogueira & 16,13 & 22,78 & 57,10 & 3,99 \\
\hline Campinas & 8,64 & 24,67 & 66,56 & 0,13 \\
\hline Cosmópolis & 13,17 & 34,41 & 52,19 & 0,23 \\
\hline Engenheiro Coelho & 13,59 & 24,67 & 50,86 & 10,88 \\
\hline Holambra & 5,63 & 17,95 & 64,59 & 11,82 \\
\hline Hortolândia & 7,36 & 30,41 & 62,22 & 0,01 \\
\hline Indaiatuba & 8,37 & 40,94 & 50,26 & 0,43 \\
\hline Itatiba & 7,46 & 48,05 & 43,62 & 0,88 \\
\hline Jaguariúna & 5,31 & 34,27 & 59,94 & 0,49 \\
\hline Monte Mor & 10,23 & 47,86 & 41,72 & 0,19 \\
\hline Morungaba & 8,78 & 47,59 & 39,44 & 4,18 \\
\hline Nova Odessa & 6,71 & 38,45 & 54,70 & 0,14 \\
\hline Paulínia & 6,79 & 33,94 & 59,25 & 0,03 \\
\hline Pedreira & 14,08 & 28,75 & 56,61 & 0,56 \\
\hline Santa Bárbara d'Oeste & 10,24 & 42,54 & 46,80 & 0,42 \\
\hline Santo Antônio de Posse & 12,73 & 19,45 & 59,54 & 8,27 \\
\hline Sumaré & 8,23 & 46,44 & 45,25 & 0,08 \\
\hline Valinhos & 8,76 & 36,92 & 53,20 & 1,12 \\
\hline Vinhedo & 1,86 & 39,12 & 58,90 & 0,12 \\
\hline Fonte: & & & & \\
\hline
\end{tabular}

Fonte: dados sistematizados pela autora a partir do Censo do IBGE de 2010. Obs.: os percentuais foram obtidos pela autora considerando a somatória do valor adicionado total de cada setor de atividade.

Cabe lembrar que os dados apresentados visam apenas dar um panorama das principais características da Região Metropolitana de Campinas, de modo que se possa compreender melhor as peculiaridades de cada município ao se discutir tanto suas legislações quanto a produção de HIS e a expansão delas no território, questões que serão discutidas nos capítulos seguintes. 


\section{CAPÍTULO II $\mid$ Os municípios da Região Metropolitana de Campinas e seu aparato legal para a produção de Habitação de Interesse Social}

O planejamento urbano habitacional, incluído em planos metropolitanos, planos diretores, planos ou políticas locais de habitação, deveria considerar sua região de abrangência, uma vez que questões dessa natureza somente são possíveis de solução se forem tratadas regionalmente. Maricato, ao analisar as diferentes regiões metropolitanas no Brasil, enfatiza essa condição.

Não é raro a orientação urbanística de um município prejudicar os demais.
Macrodrenagem, coleta e distribuição de água tratada, transporte de cargas
e passageiros, coleta e tratamento de esgoto, habitação, uso e ocupação do
solo são temas que exigem um tratamento integrado na metrópole. Apesar
desse quadro, a questão metropolitana está numa espécie de "limbo" no
Brasil. Não há integração administrativa e, o que é pior, parece que ninguém
se interessa pelo assunto (MARICATO, 2011b, p. 10).

Considerando a importância de se planejar a habitação de forma integrada, especialmente na Região Metropolitana de Campinas, cujo plano habitacional apresentou-se mais como um primeiro diagnóstico do problema habitacional do que como um instrumento de planejamento, apresenta-se a seguir um levantamento dos planos diretores dos vinte municípios da RMC e a tríade fundo, conselho e plano local de habitação. Esse conjunto de instrumentos habitacionais não representa um planejamento metropolitano integrado, mas é um esforço de compreender os objetivos deles, a existência, a delimitação e a utilização do instrumento ZEIS (Zonas Especiais de Interesse Social), bem como a (des)articulação com outras instâncias de governo.

As legislações apresentadas foram levantadas durante os anos 2013 e 2014, com atualizações em 2015, ressaltando-se a dificuldade para obtenção desse material, em princípio, público. Foram realizadas buscas nos sites das câmaras e das prefeituras municipais, além de contato via telefone e visitas, quando as informações eram insuficientes ou divergentes. Compreende-se que esse levantamento permite a construção de um quadro das legislações habitacionais na RMC e, ainda que não reflita as realidades efetivamente praticadas nos municípios, permite compreender a articulação entre estes, assim como perceber a diversidade de estruturas e aparato institucional, técnico e legal dentro de uma mesma região metropolitana.

Para a leitura das análises das regulamentações municipais a seguir, a despeito de haver um esforço para sistematizar as informações de modo que sejam possíveis algumas comparações, ressalta-se que devem ser consideradas as especificidades de cada 
município $^{19}$. Pois, embora metodologicamente as leis, os planos e os instrumentos possam compor um mesmo plano comparativo, é fundamental perceber as peculiaridades municipais.

\subsection{Planos Diretores nos Municípios da RMC}

Desde a aprovação do Estatuto da Cidade em 2001, Lei Federal no 10.257, torna-se obrigatório que todas as cidades com mais de 20 mil habitantes ou que estão contidas em regiões metropolitanas elaborem seus planos diretores. Essa regulamentação municipal determina a área urbana e rural do município, assim como pode estabelecer as Zonas Especiais de Interesse Social (ZEIS), parcelamento, edificação ou utilização compulsório, direito de preempção e outros instrumentos que podem ser muito importantes para a constituição da política habitacional do município.

Apesar do fato de os instrumentos serem estabelecidos por uma mesma Lei Federal, o Estatuto da Cidade, cada município, em seu plano diretor, utiliza-os de forma específica, muitas vezes desconsiderando questões colocadas por municípios adjacentes. Considera-se a grande diversidade entre essas legislações em razão da própria capacidade técnica de cada município e a forma como os planos foram elaborados.

São relacionadas a seguir as principais questões referentes à habitação nos planos diretores vigentes (em 2014) nos 20 municípios da RMC. Em primeiro lugar, será abordado o instrumento ZEIS (Zona Especial de Interesse Social) nos planos diretores da Região Metropolitana de Campinas. Após esse item, serão discutidos os outros instrumentos que podem ser utilizados para Habitação de Interesse Social: outorga onerosa do direito de construir; transferência do direito de construir; direito de preempção; disponibilização de assistência técnica, jurídica e social à população; Estudo de Impacto de Vizinhança (EIV); consórcio imobiliário; e operação urbana. Destaca-se que serão apresentados quais municípios estabelecem os instrumentos de forma direcionada à Habitação de Interesse Social, e não simplesmente o estabelecimento do instrumento.

Após a discussão sobre esses instrumentos, dispõe-se, no item "A Diversidade de Instrumentos Urbanísticos voltados à Habitação de Interesse Social" (p. 60), a apresentação de três grupos de municípios da Região Metropolitana de Campinas, segundo a utilização desses instrumentos em seus planos diretores. Isso de modo que seja possível perceber, primeiro, quais deles são mais utilizados na RMC; depois, notar quais municípios possuem

${ }^{19}$ Alguns dos dados, que auxiliam na compreensão da diversidade de características municipais, podem ser verificados no último item do capítulo anterior. 
uma maior quantidade de ferramentas em seus planos diretores em benefício da Habitação de Interesse Social. Cabe lembrar que instituir o instrumento é o primeiro passo, mas não se pode vinculá-lo diretamente a uma maior ou mais qualitativa produção de Habitação de Interesse Social.

\subsubsection{Os meandros do instrumento ZEIS na Região Metropolitana de}

\section{Campinas}

Aborda-se agora como as Habitações de Interesse Social (HIS) são definidas nos planos diretores dos municípios da Região Metropolitana de Campinas, relacionam-se os municípios que instituem as Zonas Especiais de Interesse Social (ZEIS) para essas HIS e quais dessas ZEIS de fato foram utilizadas para a produção de habitação nos municípios da Região Metropolitana de Campinas. Pretende-se perceber as relações entre o instrumento ZEIS e a produção de HIS na Região Metropolitana de Campinas, considerando a diversidade de conceitos que tangem a esse instrumento, assim como a dificuldade de sua implementação.

O instrumento Zonas Especiais de Interesse Social (ZEIS), formulado na década de 1980, transforma-se em um dos principais instrumentos de política fundiária após sua inclusão no Estatuto da Cidade (CYMBALISTA, 2005; ROLNIK; SANTORO, 2013). O Estatuto da Cidade discorre sobre diversos instrumentos legais que permitem avançar nos conceitos estabelecidos pela Constituição: a função social da cidade e da propriedade urbana. O capítulo II do Estatuto apresenta diversos instrumentos da política urbana, destacando-se a obrigatoriedade da elaboração de planos diretores para todas as cidades contidas em regiões metropolitanas.

São apresentados os planos diretores dos municípios da Região Metropolitana de Campinas e como esses planos, aprovados após o Estatuto da Cidade, incorporaram ou não o instrumento ZEIS. Com as ZEIS, é possível contemplar dois tipos de áreas nos zoneamentos das cidades: A) as ocupadas de forma irregular e precária, de modo que haja normas específicas para a sua regularização; e B) as áreas vazias, preferencialmente dotadas de infraestrutura e com boa localização para a produção de novas Habitações de Interesse Social (HIS), com parâmetros urbanísticos diferenciados. Destaca-se o segundo tipo, por representar na cidade uma forma de "proteção" em relação ao mercado imobiliário, garantindo o acesso das classes de baixa renda a áreas valorizadas. (ROLNIK; SANTORO, 2013; SILVA, 2013). 
A partir de uma leitura da incidência da regulação urbanística sobre o processo de exclusão socioterritorial (Rolnik, 1997) a hipótese que alimentou o estabelecimento de ZEIS nos zoneamentos das cidades foi a de que intervir sobre as regras que definem uso e ocupação do solo poderia operar no sentido de ampliar o acesso à terra para populações que não encontram esta possibilidade no mercado. A possibilidade de utilização das ZEIS para reservar espaços para habitação de interesse social no ordenamento territorial das cidades invertendo a lógica espacial do zoneamento como reserva de terra e proteção de valores de solo para os mercados de média e alta renda também, em tese, deveria colaborar para uma boa utilização de áreas subutilizadas e vazias mais centrais, característica também apontada pela literatura como parte integrante do modelo socioespacial hegemônico nas cidades latino-americanas (ROLNIK; SANTORO, 2013, p. 2).

Conceitualmente, o instrumento ZEIS de áreas vazias é fundamental para garantir nas cidades áreas bem localizadas, dotadas de infraestrutura e serviços para novas Habitações de Interesse Social. Apresenta-se a seguir a utilização do instrumento ZEIS na Região Metropolitana de Campinas, para tentar compreender como de fato esse instrumento foi utilizado ou discutido pelos planos diretores municipais. Os municípios serão divididos em três grupos: aqueles que instituem as ZEIS, aqueles que abordam o instrumento de forma vaga e aqueles que não utilizaram do instrumento em seus planos diretores.

\subsubsection{ZEIS: municípios que as instituem e a quem se destinam}

Entre os vinte municípios da Região Metropolitana de Campinas, apenas metade deles instituem as Zonas Especiais de Interesse Social (ZEIS) para o provimento de HIS: Americana, Artur Nogueira, Campinas, Cosmópolis, Hortolândia, Itatiba, Morungaba, Pedreira, Santa Bárbara d'Oeste e Vinhedo (ver Quadro 1, p. 42; Mapa 3, p. 59 e Quadro 4, p. 65). Apesar do instrumento ZEIS, que permeia os planos diretores desses municípios, estar pautado no Estatuto da Cidade, percebe-se nos planos uma grande diversidade de significados na definição das Habitações de Interesse Social (HIS), especialmente na faixa de renda a que se destina essa produção habitacional.

Dos dez municípios que instituem as ZEIS, sete deles (cf. Quadro 1, p. 42) estabelecem os dois tipos: ZEIS de regularização e ZEIS de indução ${ }^{20}$, sendo o primeiro áreas delimitadas onde já existem habitações populares e o segundo áreas vazias demarcadas para a proposição de nova HIS. A pesquisa concentra-se no segundo tipo, não porque um seja mais importante que outro para a cidade, mas por representar uma forma

\footnotetext{
${ }^{20}$ Esta nomenclatura - regularização e indução - é utilizada pelo município de Campinas, mas outros municípios utilizaram conceitos semelhantes, mesmo que com outra denominação, e que aqui eles foram unificados.
} 
de "reserva de área" para produção de Habitação de Interesse Social (HIS) e a produção de HIS na Região Metropolitana de Campinas ser o enfoque da presente tese.

Destacam-se os municípios de Americana, Artur Nogueira, Campinas, Itatiba e Vinhedo, que instituem os dois tipos de ZEIS e apresentam mapa com a localização de cada tipo. Os municípios de Hortolândia, Morungaba, Pedreira e Santa Bárbara d'Oeste apresentam mapa com a localização das ZEIS, mas não distinguem se elas são de indução ou de regularização, sendo que, no caso de Hortolândia, os dois tipos são estabelecidos no texto do plano diretor. O município de Cosmópolis, embora estabeleça os dois tipos de ZEIS no plano diretor, não apresenta nenhum mapa com a localização de ZEIS (ver Quadro 1).

\section{Quadro 1 - Municípios que instituem ZEIS em seus planos diretores}

\begin{tabular}{|c|c|c|c|c|c|c|c|c|c|c|}
\hline $\begin{array}{c}\text { Destacam-se a existência destes } \\
\text { itens nos Planos Diretores } \\
\text { Municipais: }\end{array}$ & 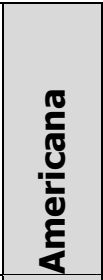 & 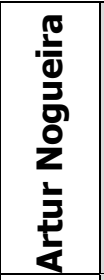 & 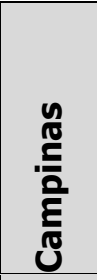 & 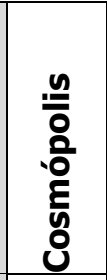 & 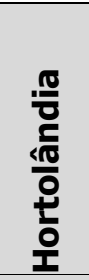 & 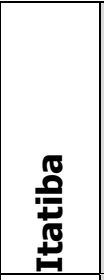 & 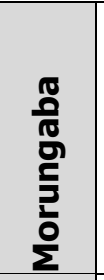 & 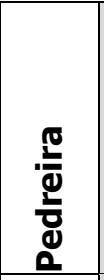 & 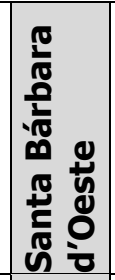 & $\begin{array}{l}\text { 음 } \\
\frac{d}{5} \\
\text { 녹 }\end{array}$ \\
\hline Ano do Plano Diretor & 2008 & 2007 & 2006 & 2007 & 2008 & 2011 & 2006 & 2008 & 2006 & 2007 \\
\hline Institui as ZEIS & $\mathbf{X}$ & $\mathbf{X}$ & $\mathbf{X}$ & $\mathbf{X}$ & $\mathbf{X}$ & $\mathbf{X}$ & $\mathbf{X}$ & $\mathbf{X}$ & $\mathbf{X}$ & $x$ \\
\hline $\begin{array}{l}\text { Estabelece zona(s) específica(s) para a } \\
\text { implantação das ZEIS de habitação }\end{array}$ & $\mathbf{x}$ & & $\mathbf{x}$ & & & & & & & \\
\hline $\begin{array}{l}\text { Especifica os limites das áreas de ZEIS } \\
\text { no texto do plano diretor (ou em texto } \\
\text { anexo) }\end{array}$ & $x$ & & & & & & & & & \\
\hline $\begin{array}{l}\text { Apresenta mapa anexo com a } \\
\text { localização das ZEIS }\end{array}$ & $\mathbf{X}$ & $\mathbf{X}$ & $\mathbf{X}$ & & $\mathbf{x}$ & $\mathbf{x}$ & $\mathbf{x}$ & $\mathbf{X}$ & $\mathbf{X}$ & $\mathbf{x}$ \\
\hline $\begin{array}{l}\text { Apresenta a classificação de cada tipo } \\
\text { de ZEIS (regularização e indução) em } \\
\text { mapa anexo }\end{array}$ & $\mathbf{x}$ & $\mathbf{x}$ & $\mathbf{x}$ & & & $\mathbf{x}$ & & & & $\mathbf{X}$ \\
\hline $\begin{array}{l}\text { Propõe a criação de ZEIS para HIS de } \\
\text { regularização }\end{array}$ & $\mathbf{x}$ & $\mathbf{X}$ & $\mathbf{X}$ & $\mathbf{X}$ & $\mathbf{X}$ & $\mathbf{X}$ & & & & $\mathbf{X}$ \\
\hline $\begin{array}{l}\text { Propõe a criação de ZEIS para HIS de } \\
\text { indução }\end{array}$ & $\mathbf{x}$ & $\mathbf{x}$ & $\mathbf{x}$ & $\mathbf{x}$ & $\mathbf{x}$ & $\mathbf{x}$ & & & & $\mathbf{X}$ \\
\hline $\begin{array}{l}\text { Municípios que produziram HIS a partir } \\
\text { das ZEIS instituídas pelos planos } \\
\text { diretores (ZEIS VAZIAS) }\end{array}$ & & & $\mathbf{x}$ & & $\mathbf{x}$ & $\mathbf{x}$ & & & & \\
\hline
\end{tabular}

Fonte: tabela elaborada pela autora a partir da análise dos planos diretores municipais (vigentes em 2014).

No município de Americana o instrumento ZEIS (LC 4.597/2006), voltado às Habitações de Interesse Social, destina-se à população com renda familiar máxima de 10 salários mínimos. O loteamento nas ZEIS deve apresentar lotes com testada mínima de 7,50 m e $150 \mathrm{~m}^{2}$ de área, sem permissão de desdobro, e deve ainda estar vinculado a programas

\footnotetext{
${ }^{21}$ Neste trabalho, considera-se apenas a produção de HIS em ZEIS "vazias" - aquelas utilizadas como reserva de área. Portanto, alguns municípios que utilizaram as ZEIS de regularização não estão demarcados na tabela.
} 
públicos habitacionais ou entidades sem fins lucrativos, após manifestação favorável da Secretaria de Planejamento, Habitação e Meio Ambiente.

Cabe destacar o artigo 84 do plano diretor de Americana, o qual permite uma "flexibilidade" em relação às áreas demarcadas como ZEIS, pois, se os proprietários de glebas privadas doarem $30 \%$ ao município, podem ter as áreas remanescentes dessas glebas desafetadas de ZEIS. Para tal, é necessário que a área doada seja contígua à área loteada, não apresente restrição ambiental de uso e seja analisada pela Secretaria de Planejamento e Controladoria. Ressalta-se que a área remanescente (das ZEIS) pode ser retalhada em cinco partes ou implantar empreendimentos seguindo as doações de $20 \%$ para arruamento, $8 \%$ para área institucional e 7\% para o sistema de lazer, ou seja, valores semelhantes ao estabelecido pela lei federal de loteamentos. Caso ultrapasse os dois anos de prazo para retalhamento para doação ao município, o IPTU progressivo será aplicado na área, podendo ser desapropriado caso não seja pago.

Em Artur Nogueira, no artigo 66 do plano diretor ${ }^{22}$ definem-se as Zonas Especiais de Interesse Social (ZEIS) como áreas territoriais "destinadas prioritariamente à regularização fundiária, urbanização e à produção de Habitação de Interesse Social para população de baixa renda" (LC 441/2007). Elas são divididas em duas categorias: ZEIS A - as áreas que contêm habitações precárias e irregulares, necessitando de diversos tipos de infraestrutura e/ou equipamentos ou remoções pontuais; ZEIS B - vazios urbanos voltados para uso habitacional, adequados para empreendimentos de interesse social, sejam habitações ou seus respectivos equipamentos. Não há descrição dos perímetros das ZEIS no texto da Lei, mas elas estão delimitadas no anexo XII (mapa XII), onde os dois tipos de ZEIS podem ser observados. No plano diretor, é citada a possibilidade de aplicação dos instrumentos do Estatuto para a regularização fundiária nas ZEIS.

Para os planos de urbanização das ZEIS de Artur Nogueira, há especificações para o diagnóstico, para os projetos urbanísticos e as diretrizes no artigo 81 do plano diretor. Todas as ZEIS (tipo A) devem apresentar uma comissão gestora (com atuais e futuros moradores), e o Executivo deve fornecer assistência técnica, jurídica e social à população moradora. Tanto os proprietários de glebas quanto as entidades dos moradores das ZEIS devem

\footnotetext{
${ }^{22}$ No capítulo II do plano diretor, aborda-se a questão da habitação, cujos objetivos de sua política são: assegurar o direito à moradia; coibir os assentamentos inadequados nas áreas de preservação e nas áreas públicas; promover o uso habitacional nas áreas com infraestrutura consolidada, utilizando instrumentos do Estatuto da Cidade quando necessário; propiciar a participação da iniciativa privada na promoção de habitações para a classe de baixa renda, especialmente nos espaços vazios da cidade; e garantir o equilíbrio entre os demais usos e o habitacional. Destaca-se, na Política de Desenvolvimento Urbano, a garantia do direito constitucional à moradia digna e à regularização, sendo que, para o plano diretor, a utilização da produção habitacional é uma das formas de uma propriedade cumprir a sua função social.
} 
apresentar propostas para a urbanização das áreas. As áreas públicas podem ser desafetadas de seu uso quando necessárias para o plano de urbanização de ZEIS. O poder público na urbanização de ZEIS deve implantar áreas livres, equipadas para uso público na dimensão adequada à população prevista, conforme o número de habitantes.

A Seção VI do plano diretor de Campinas (arts. 84 a 87, LC 15/2006) trata do instrumento Zonas Especiais de Interesse Social (ZEIS), cuja instituição ocorre para o cumprimento dos objetivos da política de habitação ${ }^{23}$. As ZEIS são classificadas em: de Indução - que contemplam áreas não edificadas, subutilizadas ou não utilizadas destinadas à produção de HIS - e de Regularização - que abrangem áreas de ocupações "desorganizadas" da população de baixa renda em áreas públicas, privadas ou resultantes de parcelamentos irregulares.

Nas ZEIS de indução ${ }^{24}$, devem ser priorizadas as áreas que desfrutam de infraestrutura e equipamentos em seu entorno. Os perímetros dessas ZEIS não estão descritos no texto da lei, mas podem ser observadas suas delimitações no mapa "ZEIS de Indução" (anexo VIII). Já os novos perímetros e a alteração dos instituídos pelo plano diretor devem ser aprovados pelos planos locais de gestão ou por lei decorrente do plano setorial de habitação. Quanto às ZEIS de regularização, coloca-se que deve ser preservada, quando possível, "a tipicidade da ocupação local", considerando as exigências técnicas para a execução da infraestrutura, circulação e garantia de condições de habitabilidade. $O$ anexo VII dessa lei apresenta um mapa denominado ZEIS de regularização e uma tabela com a relação de todas as ZEIS e sua classificação em favelas, ocupações ou núcleos. A demarcação de novos perímetros de ZEIS de regularização ou a alteração dos delimitados devem ocorrer por meio de lei específica.

Observa-se, no mapa que delimita as ZEIS de indução (anexo VIII), que são demarcadas 11 áreas, e 10 delas localizam-se a sudoeste da Rodovia Anhanguera ${ }^{25}$. Há

\footnotetext{
${ }^{23} \mathrm{O}$ Capítulo V (art. 50 e 51) do plano diretor de Campinas refere-se à política de habitação municipal, cujos objetivos são: garantir a todos o acesso à moradia, com prioridade para a população de baixa renda; a redução do déficit de habitação, a partir da promoção de conjuntos de interesse social e suscitando formas de participação da iniciativa privada; a reversão do processo de segregação sócio espacial, por meio do cumprimento da função social da cidade e da propriedade, com a indução à produção de HIS nos vazios urbanos providos de infraestrutura em suas imediações; a promoção de requalificação urbanística e regularização fundiária dos assentamentos precários e irregulares; a melhoria das construções em assentamentos precários e a remoção e reassentamento de famílias que moram em áreas de risco ou inadequada para habitação.

${ }^{24}$ Se as ZEIS de indução apresentarem área com até $300 \mathrm{mil} \mathrm{m}^{2}$, elas devem seguir as regulamentações estabelecidas pela Lei municipal $n^{\circ} 10.410 / 2000$, que dispõe sobre empreendimentos habitacionais de interesse social. Para ZEIS de indução com áreas superiores a $300 \mathrm{mil} \mathrm{m}^{2}$, a área excedente deve seguir as regulamentações da Lei de Uso e Ocupação do Solo.

25 A área a sudoeste da Rodovia Anhanguera no município de Campinas caracteriza-se por abrigar majoritariamente população de baixa renda, com diversas ocupações e favelas.
} 
apenas uma pequena área de ZEIS de indução delimitada a leste dessa rodovia. De forma semelhante, no mapa do anexo VII, que apresenta as ZEIS de regularização, observa-se que mais da metade dessas áreas localiza-se a sudoeste da Rodovia Anhanguera.

Conforme artigo 87 (LC 15/2006), os empreendimentos habitacionais de interesse social de Campinas são regulamentados pela Lei Municipal no 10.410/2000 e estão restritos às seguintes áreas: nas ZEIS de indução demarcadas no plano diretor ou em áreas das macrozonas 5 e 9 ou nas seguintes áreas de planejamento da macrozona 4: 18, 23, 25 e 31 .

O município de Cosmópolis define em seu plano diretor (LC 2.949/20076) ZEIS como "porções do território destinadas, prioritariamente, à recuperação urbanística, à regularização fundiária e à produção de Habitações de Interesse Social - HIS ou do Mercado Popular - HMP, incluindo a recuperação de imóveis degradados, a provisão de equipamentos sociais e culturais, espaços públicos, serviço e comércio de caráter local", sendo as HIS voltadas a famílias com até 3 salários mínimos de renda, cujo padrão do imóvel deve ser de até $50 \mathrm{~m}^{2}$ de área ${ }^{27}$, com máximo de 1 banheiro e 1 garagem. As HMP são para famílias com renda máxima de 6 salários mínimos, com unidades de até 2 banheiros, 1 vaga de garagem e até $70 \mathrm{~m}^{2}$. Quando as ZEIS forem utilizadas para parcelamento do solo, estabelece-se a área mínima de $150 \mathrm{~m}^{2}$ e máxima de $250 \mathrm{~m}^{2}$ para os lotes.

Embora o plano diretor de Cosmópolis não demarque as ZEIS, coloca que seus perímetros são delimitados conforme o mapa de zoneamento, que deve constar da Lei de Uso de Ocupação do Solo do Município. A Lei de Uso e Ocupação do Solo, Lei Complementar n० 3.390/2011, apresenta em seu texto a descrição do perímetro de uma ZEIS, entretanto, o seu anexo II, o mapa de zoneamento, não apresenta a localização dessa ZEIS, nem ao menos consta essa zona em sua legenda.

No plano diretor de Hortolândia, entre as funções sociais do município, destaca-se a garantia de "condições dignas de moradia" (art. 30, inciso I). O Título VIII aborda especificadamente a questão habitacional e define-se como objetivo da política de habitação ${ }^{28}$ a redução do déficit e da inadequação de moradias, possibilitando melhores condições de vida e habitabilidade, coibindo as ocupações irregulares e oferecendo alternativas habitacionais. No inciso V do artigo 17, definem-se as ZEHIS (Zonas Especiais de

\footnotetext{
${ }^{26}$ A Lei Complementar Municipal de Cosmópolis 2.949/2007 sofreu alterações em 2009 por meio da Lei 3.129.

${ }^{27}$ A área pode ser maior quando as famílias beneficiadas estiverem envolvidas na produção da moradia.

${ }^{28}$ Conforme o artigo 107, para atingir os objetivos da Política de Habitação, o Executivo deve formular Plano Municipal de Habitação, cujos itens mínimos são: diagnóstico da situação habitacional; objetivos; diretrizes e metas dessa política no município; estimativa de déficit e da inadequação de moradia; inclusão de novas áreas de ZEHIS II para a produção de habitação; definição dos conceitos de Habitação de Interesse Social e Habitação de Mercado Popular; estabelecimento de critérios para regularização das áreas de ZEHIS I (art. 101, Lei 2092/2008).
} 
Habitação de Interesse Social) como "áreas onde há interesse público em ordenar a ocupação por meio de urbanização e regularização fundiária, em implantar ou complementar programa habitacional de interesse social, e que se sujeitam a critérios especiais de parcelamento, uso e ocupação do solo". Elas dividem-se em duas categorias: ZEHIS I áreas ocupadas por favelas ou loteamentos irregulares passíveis de regularização fundiária e urbanística; e ZEHIS II - áreas não edificadas, cujo interesse público seja a implantação de empreendimentos habitacionais de interesse social. Por semelhança de conceito, pode-se dizer que são instituídas as ZEIS de regularização (ZEHIS I) e ZEIS de indução (ZEHIS II) (Quadro 1, p. 42 e Quadro 4, p. 65). Os perímetros das ZEHIS não estão descritos no texto da Lei, mas a demarcação dessas zonas, tanto do tipo I quanto do II, pode ser observada no mapa de ZEHIS ${ }^{29}$, anexo III do plano diretor.

O plano diretor de Hortolândia estabelece que os Empreendimentos Habitacionais de Interesse Social (EHIS) devem seguir as regulamentações da Lei Municipal no 1.905/2007, a qual coloca que os EHIS, que podem ocorrer nas ZEHIS, são voltados à população com faixa de renda de até 6 salários mínimos, e que, para os parcelamentos, os lotes devem ter entre 125 e $250 \mathrm{~m}^{2}$.

Em Itatiba, o artigo 55 do plano diretor (Lei 4325/2011) coloca que a oferta de moradia ocorrerá a partir da demanda existente e também que será dimensionada conforme o crescimento populacional futuro. Para tal, podem-se estabelecer espaços propícios, providos de infraestrutura e serviços, em áreas denominadas Zonas de Especial Interesse Social (ZEIS), para a implantação de novos núcleos residenciais, de maior densidade, a fim de promover a sua viabilização econômico-financeira, e estimulando a implantação de: "Empreendimentos Habitacionais de Interesse Social" (EHIS) e "Empreendimentos Habitacionais de Mercado Popular" (EHMP). As diretrizes da política habitacional são, entre outras, "instituir as ZEIS" e criar um "Banco de Terras" voltado à produção de Habitações de Interesse Social (HIS) por meio dos recursos oriundos da aplicação dos instrumentos urbanísticos e institutos jurídicos pertinentes.

A seção VII do plano diretor de Itatiba trata das Zonas Especiais de Interesse Social, cuja definição é "a parcela de área urbana instituída pelo Plano Diretor ou definida por outra lei municipal, destinada predominantemente à moradia de população de baixa renda e sujeita a regras específicas de parcelamento, uso e ocupação do solo" (art. 145, § 10). Elas classificam-se em ZEIS de indução, cujas áreas vazias ou subutilizadas são necessárias para

\footnotetext{
${ }^{29}$ Destaca-se que no artigo 102, no plano diretor de Hortolândia, fica estabelecido que, sempre que julgar necessário, a partir do déficit e de demandas futuras, o Poder Municipal pode demarcar novas Zonas Especiais de Habitação de Interesse Social, por meio de legislação própria.
} 
a implantação de HIS para a população com renda até 6 salários mínimos, e ZEIS de requalificação, cujas áreas são ocupadas pela população de baixa renda em assentamentos irregulares e precários. O mapa do anexo $\mathrm{V}$ do plano diretor institui as ZEIS de requalificação ${ }^{30}$ e de indução ${ }^{31}$ (15 áreas). Além disso, serão consideradas aquelas definidas no Plano Local de Habitação de Interesse Social.

No plano diretor de Morungaba, colocam-se como objetivos da política de habitação: garantir o acesso à terra urbanizada e à moradia; promover a produção de HIS e Habitação de Mercado Popular - HMP pela iniciativa privada; garantir a sustentabilidade nos programas habitacionais; apoiar a formação de cooperativas e associações de autogestão; incentivar projetos de interesse social, por meio de normas específicas, "evitando a 'elitização' das normas urbanísticas" (art. 17, Lei no 1.159/2006).

O capítulo XIV do plano de Morungaba trata das Habitações de Interesse Social (HIS) e estabelecem-se as diretrizes para sua implantação. Entre essas diretrizes, destaca-se aqui a delimitação das Zonas Especiais de Interesse Social, que deve ocorrer conforme o mapa anexo do plano diretor, tanto para a promoção de habitação de interesse social quanto para reurbanização e regularização fundiárias. No mapa anexo III $^{32}$, foi possível observar a localização de duas áreas de ZEIS, entretanto, não ficam definidas no mapa se são ZEIS de indução (vazias) ou de regularização (ocupadas). No anexo IV do plano diretor, que estabelece os parâmetros urbanísticos, coloca-se uma área mínima do lote de ZEIS de 125 $\mathrm{m}^{2}$, e nenhum outro parâmetro é estabelecido.

O capítulo III do plano diretor (Lei 2.792/08) de Pedreira aborda a Política de Habitação ${ }^{33}$ do município, que visa assegurar o direito à moradia, compreendido como

\footnotetext{
${ }^{30}$ Para a requalificação, o Executivo pode oferecer a assessoria técnica, jurídica e social à população moradora. Tanto os proprietários das áreas quanto as representações dos moradores de ZEIS podem apresentar ao Executivo propostas para o plano de urbanização. Quando necessário, as áreas públicas serão desafetas de seu uso para implementação do plano de urbanização, que poderá abranger mais de uma ZEIS ( $1^{\circ}$ ao $\S 4^{\circ}$ do art. 146 da Lei municipal 4.325/2011).

${ }^{31}$ O plano de urbanização de cada ZEIS será estabelecido por decreto municipal, que deve prever: diretrizes, índices e parâmetros para parcelamento e uso do solo e implantação de infraestrutura; diagnóstico com análise físico-ambiental, urbanística e caracterização da população residente; os projetos e as intervenções urbanísticas necessárias para a área, com a definição da infraestrutura e implantação de serviços e equipamentos sociais; instrumentos aplicáveis à área, condições para remembramento de lotes; forma de participação popular na implementação e gestão das intervenções; forma de integração das ações dos diversos setores públicos que interferem nas ZEIS; fonte de recursos para intervenções; atividades de geração de emprego e plano de ação social (art. 146, Lei municipal 4.325/2011).

${ }^{32}$ No município de Morungaba, as áreas de ZEIS estão marcadas na legenda do mapa, anexo III do plano diretor (Lei no 1.159/2006), mas há dificuldade para localizar essas áreas na cidade, visto que as cores da legenda se confundem. No entanto, a Lei no 1.364 de 2010 altera os anexos II e III do plano diretor, e, assim, torna-se identificável a delimitação de duas áreas de ZEIS no mapa de Morungaba (anexo III).

${ }^{33}$ São relacionadas no plano diretor de Pedreira as seguintes formas de atuação da política de habitação: ação direta na produção, melhoria e regularização habitacional; apoio técnico e financeiro às iniciativas autogeridas de cooperativas; incentivos aos empreendimentos privados de HIS e ações em parceria com entidades comunitárias
} 
necessidade básica. O artigo 32 trata especificadamente das Zonas Habitacionais de Interesse Social (ZHIS), que são definidas como áreas municipais a serem reguladas e delimitas por lei municipal. Essas ZHIS ${ }^{34}$ são voltadas à promoção de Habitação de Interesse Social ${ }^{35}$ nos seguintes casos: terrenos (públicos ou privados) ocupados por favelas ou por população de baixa renda; loteamentos irregulares; áreas com concentração de habitação coletiva precária de aluguel, em que haja o interesse público em promover a regularização do parcelamento, a urbanização, a complementação da infraestrutura ou a regularização da posse da terra; ou ainda, terrenos não utilizados ou subutilizados necessários para a implantação de programas de HIS. O plano diretor não utiliza a denominação ZEIS, entretanto, devido à semelhança conceitual das ZHIS, considerou-se a instituição do instrumento ZEIS (cf. Quadro 1, p. 42 e Quadro 4, p. 65).

Ressalta-se que em 2010, por meio da Lei municipal no 3.068, são instituídas 14 áreas de ZHIS em Pedreira, mas não são discriminadas se de indução (vazias) ou de regularização (ocupadas). As Habitações de Interesse Social são voltadas para famílias com renda de até 6 salários mínimos, e no perímetro das ZHIS pode haver o parcelamento em lotes, desde que seja considerada a área mínima de $140 \mathrm{~m}^{2}$ (art. $3^{\circ}$ e 50, Lei 3.068/10). 0 mapa anexo localiza as 14 Zonas Habitacionais de Interesse Social (ZHIS) definidas na lei, entretanto, não as classifica como áreas vazias (indução) ou áreas ocupadas (regularização), mas, conforme informação da Secretaria de Promoção Social de Pedreira (em 01/2016), todas as ZHIS instituídas foram para regularização de áreas.

No caso de Santa Bárbara d'Oeste, não são descritas as ZEIS no plano diretor, entretanto criam-se as "Macrozonas de Interesse Social" (MIS), que são definidas como áreas "destinadas à implantação de programas e projetos habitacionais de interesse social, desenvolvidos por órgãos ou entidades da Administração Pública com atuação específica nessa área em atendimento às políticas habitacionais do Município" (art. 16, LC 28/2006). Devido à semelhança do conceito, considerou-se que o município institui ZEIS em seu plano.

Coloca-se no plano diretor (art. 39) de Santa Bárbara que o parcelamento nas Macrozonas de Interesse Social pode ter lotes de no mínimo $140 \mathrm{~m}^{2}$. Posteriormente, a Lei

e privadas; viabilização de assistência jurídica para conflitos relacionados à locação e à propriedade, principalmente por meio de convênios com entidade; aprimoramento de esforços públicos, comunitários e privados para melhorar a qualidade e diminuir custos da habitação (Lei 2.792/2008).

${ }^{34}$ Os lotes aprovados como ZHIS não poderão ser remembrados, exceto para empreendimentos habitacionais de interesse social, com anuência do Departamento de Habitação da Secretaria de Promoção Social de Pedreira (art. 32, § 60 Lei 2792/08).

${ }^{35}$ Define-se Habitação de Interesse Social como aquela voltada à população com renda familiar mensal máxima de 6 salários mínimos, produzida pelo poder público municipal ou com sua expressa anuência, com no máximo 1 banheiro por unidade e 1 vaga de estacionamento para cada 2 unidades habitacionais (art. 32, § 1丷, Lei 2792/08). 
Municipal 3.670/2014 estabelece parâmetros para parcelamentos de interesse social, mas, assim como o plano diretor, não define a que faixa de renda se destinam essas habitações. Ficam estabelecidos para lotes resultantes de loteamento de interesse social: testada mínima de 7 metros (12 metros para lotes de esquina); em relação à área, para o lote de interesse social não localizado em MIS, o mínimo deve ser de $175 \mathrm{~m}^{2}$, enquanto para aqueles localizados em MIS, de $140 \mathrm{~m}^{2}$, conforme a Lei 3.670/2014.

No plano diretor de Vinhedo, o capítulo IV (art. 11, LC 66/2007) trata das moradias cuja oferta deve ser fundamentada no crescimento populacional futuro e podem ser estabelecidos "espaços propícios e adequados, já dotados de infra-estrutura e serviços setorizados em áreas denominadas, Zonas de Especial Interesse Social - ZEIS". O capítulo II aborda as ZEIS, definindo-as como áreas do território que garantem o acesso à moradia digna para a população com renda de até 12 salários mínimos, tanto para Habitação de Interesse Social ${ }^{36}$ (HIS) quanto para Habitação de Mercado Popular (HMP). Essas ZEIS dividem-se em três categorias: ZEIS 1, definidas como áreas precárias ocupadas pela população de baixa renda, que podem ser aqui classificadas como as ZEIS de Regularização; ZEIS 2, que são descritas como terrenos não utilizados ou subutilizados necessários para a implantação de programas de Habitação de Interesse Social para a população com renda de até 6 salários mínimos ${ }^{37}$, aqui classificadas como ZEIS de indução; e ZEIS 3, caracterizadas por terrenos não utilizados ou subutilizados voltados a programas de Habitação de Mercado Popular para a população de até 12 salários mínimos ${ }^{38}$.

As ZEIS, que podem ocorrer em quaisquer macrozonas do município de Vinhedo, não apresentam uma descrição do perímetro no texto do plano diretor, mas podem ser visualizadas, no anexo IX desse plano, as três categorias de ZEIS. No anexo X, ficam definidos os seguintes parâmetros para as ZEIS 2 e 3: tamanho mínimo de lote de $250 \mathrm{~m}^{2}$ e tamanho máximo de $500 \mathrm{~m}^{2}$, e tamanho máximo para lote multifamiliar de $10.000 \mathrm{~m}^{2}$, gabarito máximo de 4 pavimentos e taxa de ocupação de 0,7. Ressalta-se que, a despeito das ZEIS 2 e 3 serem voltadas para classes de renda bastante distintas, os parâmetros são exatamente os mesmos, o que pode dificultar a produção de HIS nas ZEIS 2.

\footnotetext{
${ }^{36}$ São consideradas Habitações de Interesse Social aquelas voltadas à população com renda de até 6 salários mínimos, com área útil máxima de $50 \mathrm{~m}^{2}$, sendo de apenas 1 sanitário, máximo de 1 vaga de garagem por unidade e pé-direito de 2,40 m. (art. 160, LC 66/2007).

${ }^{37}$ Para as ZEIS 2, devem ser garantidas $80 \%$ das unidades habitacionais para famílias com renda de até 3 salários mínimos e $20 \%$ para famílias com renda entre 3 e 6 salários mínimos.

${ }^{38}$ Para as ZEIS 3, devem ser garantidas $80 \%$ das unidades habitacionais para famílias com renda entre 5 e 9 salários mínimos e $20 \%$ para famílias com renda maior que 9 salários mínimos.
} 


\begin{tabular}{|c|c|c|c|c|c|c|c|c|c|c|}
\hline \multirow[b]{2}{*}{$\begin{array}{l}\text { Especificações para HIS } \\
\text { produzidas em ZEIS nos } \\
\text { planos diretores } \\
\text { municipais: }\end{array}$} & \multirow[b]{2}{*}{ 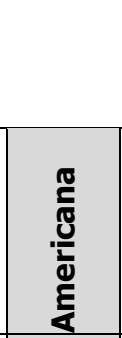 } & \multirow[b]{2}{*}{ 竞 } & \multirow[b]{2}{*}{ 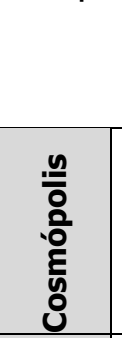 } & \multirow[b]{2}{*}{$\begin{array}{l}\frac{0}{0} \\
\frac{0}{0} \\
\frac{0}{5} \\
\frac{2}{2} \\
\frac{0}{\Sigma}\end{array}$} & \multirow[b]{2}{*}{$\begin{array}{l}\frac{0}{0} \\
\frac{\Phi}{5} \\
5\end{array}$} & \multicolumn{5}{|c|}{$\begin{array}{c}\text { Municípios com parâmetros } \\
\text { estabelecidos em outra lei }{ }^{39} \text {, porém, } \\
\text { vinculada ao Plano Diretor }\end{array}$} \\
\hline & & & & & & 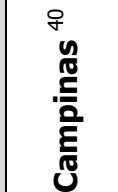 & 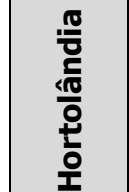 & 莣 & 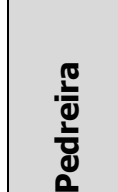 & 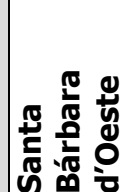 \\
\hline Ano do Plano Diretor & 2008 & 2007 & 2007 & 2006 & 2007 & 2006 & 2008 & 2011 & 2008 & 2006 \\
\hline $\begin{array}{l}\text { Faixa de renda a que se } \\
\text { destinam as HIS }\end{array}$ & $\begin{array}{c}\text { Até } 10 \\
\text { SM }\end{array}$ & $\begin{array}{c}\text { Nada } \\
\text { consta }\end{array}$ & $\begin{array}{c}\text { Até } 3 \\
\text { SM }\end{array}$ & $\begin{array}{c}\text { Nada } \\
\text { consta }\end{array}$ & $\begin{array}{l}\text { Até } 6 \\
\mathrm{SM}^{41}\end{array}$ & $\begin{array}{c}\text { Nada } \\
\text { consta }\end{array}$ & $\begin{array}{l}\text { Até } 6 \\
\text { SM }\end{array}$ & $\begin{array}{l}\text { Até } 6 \\
\text { SM }\end{array}$ & $\begin{array}{c}\text { Até } 6 \\
\text { SM }\end{array}$ & $\begin{array}{c}\text { Nada } \\
\text { consta }\end{array}$ \\
\hline Tamanho mínimo do lote & $150 \mathrm{~m}^{2}$ & $\begin{array}{c}\text { Nada } \\
\text { consta }\end{array}$ & $150 \mathrm{~m}^{2}$ & $125 \mathrm{~m}^{2}$ & $250 \mathrm{~m}^{2}$ & $126 \mathrm{~m}^{2}$ & $125 \mathrm{~m}^{2}$ & ${ }_{42}^{80 m^{2}}$ & $140 \mathrm{~m}^{2}$ & $140 \mathrm{~m}^{2}$ \\
\hline Tamanho máximo do lote & $\begin{array}{c}\text { Nada } \\
\text { consta }\end{array}$ & $\begin{array}{c}\text { Nada } \\
\text { consta }\end{array}$ & $250 \mathrm{~m}^{2}$ & $\begin{array}{l}\text { Nada } \\
\text { consta }\end{array}$ & $500 \mathrm{~m}^{2}$ & $200 \mathrm{~m}^{2}$ & $250 \mathrm{~m}^{2}$ & $\begin{array}{l}\text { Nada } \\
\text { consta }\end{array}$ & $\begin{array}{c}\text { Nada } \\
\text { consta }\end{array}$ & $\begin{array}{c}\text { Nada } \\
\text { consta }\end{array}$ \\
\hline $\begin{array}{l}\text { Tamanho mínimo da testada } \\
\text { do lote }\end{array}$ & $7,50 \mathrm{~m}$ & $\begin{array}{c}\text { Nada } \\
\text { consta }\end{array}$ & $\begin{array}{c}\text { Nada } \\
\text { consta }\end{array}$ & $\begin{array}{c}\text { Nada } \\
\text { consta }\end{array}$ & $\begin{array}{c}\text { Nada } \\
\text { consta }\end{array}$ & $7,00 \mathrm{~m}$ & $\begin{array}{l}\text { Nada } \\
\text { consta }\end{array}$ & $5,00 \mathrm{~m}$ & \begin{tabular}{|l|} 
Nada \\
consta
\end{tabular} & $\begin{array}{c}7,00 \\
\mathrm{~m}^{43} \\
\end{array}$ \\
\hline $\begin{array}{l}\text { Tamanho da Unidade } \\
\text { Habitacional }\end{array}$ & $\begin{array}{l}\text { Nada } \\
\text { consta }\end{array}$ & $\begin{array}{c}\text { Nada } \\
\text { consta }\end{array}$ & $\begin{array}{c}\text { Até } \\
50 \mathrm{~m}^{2}\end{array}$ & $\begin{array}{l}\text { Nada } \\
\text { consta }\end{array}$ & $\begin{array}{c}\text { Até } \\
50 \mathrm{~m}^{2}\end{array}$ & $\begin{array}{l}\text { De } 34 \mathrm{a} \\
80 \mathrm{~m}^{2}\end{array}$ & $\begin{array}{c}\text { Nada } \\
\text { consta }\end{array}$ & $\begin{array}{c}\text { Nada } \\
\text { consta }\end{array}$ & $\begin{array}{l}\text { Nada } \\
\text { consta }\end{array}$ & $\begin{array}{l}\text { Nada } \\
\text { consta }\end{array}$ \\
\hline $\begin{array}{l}\text { Empreendimentos realizados } \\
\text { por órgãos públicos }\end{array}$ & $\mathbf{x}$ & $\begin{array}{c}\text { Nada } \\
\text { consta }\end{array}$ & $\mathbf{x}$ & $\begin{array}{c}\text { Nada } \\
\text { consta }\end{array}$ & $\begin{array}{c}\text { Nada } \\
\text { consta }\end{array}$ & $\mathbf{x}$ & \begin{tabular}{c|} 
Nada \\
consta $^{45}$
\end{tabular} & $\begin{array}{l}\text { Nada } \\
\text { consta }\end{array}$ & $\begin{array}{c}\text { Nada } \\
\text { consta }\end{array}$ & $x^{46}$ \\
\hline $\begin{array}{l}\text { Empreendimentos realizados } \\
\text { por órgãos sem fins lucrativos }\end{array}$ & $\mathbf{x}$ & $\begin{array}{c}\text { Nada } \\
\text { consta }\end{array}$ & $\mathbf{x}$ & $\begin{array}{c}\text { Nada } \\
\text { consta }\end{array}$ & $\begin{array}{c}\text { Nada } \\
\text { consta }\end{array}$ & $\mathbf{x}$ & $\begin{array}{c}\text { Nada } \\
\text { consta }\end{array}$ & $\begin{array}{c}\text { Nada } \\
\text { consta }\end{array}$ & $\begin{array}{l}\text { Nada } \\
\text { consta }\end{array}$ & $\mathbf{x}$ \\
\hline $\begin{array}{l}\text { Empreendimentos realizados } \\
\text { por entidades privadas }\end{array}$ & NÃO & $\begin{array}{c}\text { Nada } \\
\text { consta }\end{array}$ & $x^{47}$ & $\begin{array}{l}\text { Nada } \\
\text { consta }\end{array}$ & $\begin{array}{c}\text { Nada } \\
\text { consta }\end{array}$ & $\mathbf{x}$ & \begin{tabular}{|c|} 
Nada \\
consta
\end{tabular} & $\begin{array}{c}\text { Nada } \\
\text { consta }\end{array}$ & $\begin{array}{c}\text { Nada } \\
\text { consta }\end{array}$ & $\mathbf{x}$ \\
\hline
\end{tabular}

Fonte: dados sistematizados pela autora a partir dos planos diretores municipais vigentes em 2014.

39 Nos casos dos municípios de Hortolândia e Campinas, os parâmetros listados na tabela não constam diretamente no plano diretor, mas em leis específicas para empreendimentos de interesse social: Lei Municipal de Hortolândia no 1.905/2007 e Lei Municipal de Campinas no 10.410/2000. Ressalta-se que essas leis estão citadas nos planos diretores. No caso de Itatiba, no plano diretor instituem-se as ZEIS, descrevem-se os tipos de ZEIS e estabelece-se a faixa salarial. Entretanto, os parâmetros urbanísticos diferenciados são estabelecidos posteriormente, por meio da Lei de Zoneamento de Itatiba no 4.443/2012. De forma semelhante, em Santa Bárbara, no plano diretor estabelece-se a Macrozona de Interesse Social e o tamanho mínimo de lote de $140 \mathrm{~m}^{2}$, enquanto o tamanho mínimo da testada do lote assim como os órgãos que podem realizar esses empreendimentos são estabelecidos pela Lei 3.670 de 2014. Em Pedreira, a instituição das ZEIS assim como a faixa salarial ocorrem por meio do plano diretor, enquanto o tamanho mínimo do lote e a definição de 14 ZEIS são estabelecidos pela Lei municipal 3.068/2010.

${ }^{40}$ Os lotes de esquina podem apresentar até $300 \mathrm{~m}^{2}$ de área e até $9 \mathrm{~m}$ de testada do lote.

${ }^{41}$ A faixa de renda de até 12 salários mínimos (SM) é estabelecida no artigo 160, quando são abordadas as ZEIS, definidas como porções do território destinadas a garantir o acesso à moradia à população com essa renda. No entanto, nos artigos 163 a 165, que tratam dos tipos de ZEIS, coloca-se que nas ZEIS 2, que são para HIS, a faixa é de até 6 SM e nas ZEIS 3, que são para HMP (Habitação do Mercado Popular), a faixa é de até 12 SM.

${ }^{42}$ A área mínima para lotes residenciais é de $80 \mathrm{~m}^{2}$, enquanto para lotes comerciais em ZEIS a área mínima é de $250 \mathrm{~m}^{2}$ (Lei de zoneamento de Itatiba no 4.443 de 2012).

${ }^{43}$ Se o lote for de esquina, o mínimo, em vez de 7,00 m, será de 12,00 metros (Lei 3.670 de 2014).

${ }^{44}$ Embora não conste informação sobre o tamanho máximo da habitação em ZEIS de indução, coloca-se uma taxa de ocupação máxima de $90 \%$, ou seja, quando o lote tiver o tamanho mínimo de $80 \mathrm{~m}^{2}$, a habitação poderá ter no máximo $72 \mathrm{~m}^{2}$. Ressalta-se que não é estabelecido o tamanho máximo do lote, portanto, a área construída pode ser muito maior (Lei de zoneamento de Itatiba no 4.443 de 2012).

${ }^{45}$ Nos artigos 22 a 24, coloca-se que a administração pública pode realizar parcerias com iniciativa privada, associações e para execução de obras de obras de Interesse Social.

${ }^{46} \mathrm{O}$ plano diretor de Santa Bárbara d'Oeste coloca que os projetos ou programas de interesse social nas Macrozonas de Interesse Social devem ser desenvolvidos por órgãos ou entidades da administração pública (art. 16, LC 28/2006). Enquanto a Lei 3.670 de 2014 coloca que os loteamentos de interesse social podem ser promovidos pela administração pública, pela iniciativa privada ou por proprietários de terrenos ou cooperativas e associações de moradores.

${ }^{47}$ Nas áreas de ZEIS, também é permitida a produção de HMP (Habitação de Mercado Popular), para o que o salário é de até 6 salários mínimos, as áreas das unidades de até $70 \mathrm{~m}^{2}$ e é promovida por entidades privadas. 
Percebe-se que, em Americana, a faixa de renda das ZEIS é muito maior (até 10 salários mínimos) que a dos municípios de Cosmópolis (até $3 \mathrm{SM}$ ) e de Itatiba, Hortolândia, Pedreira e Vinhedo (até $6 \mathrm{SM}$ ), além de não se estabelecer um tamanho máximo do lote, o que se verificou nos casos de Cosmópolis, Hortolândia e Vinhedo (ver Quadro 2, p. 50). Embora a faixa de renda maior inclua as outras, de 0 a 3 e de 0 a 6 salários mínimos, coloca-se em questão se as faixas inferiores são atendidas no provimento habitacional quando há uma amplitude maior da faixa de renda.

Nos municípios de Artur Nogueira, Campinas, Morungaba e Santa Bárbara d'Oeste, coloca-se que as Habitações de Interesse Social, objeto das ZEIS, são voltadas à população de baixa renda, mas não é delimitada uma faixa de renda, deixando o conceito impreciso e, portanto, sujeito a interpretações. No caso de Campinas, há uma lei que estabelece padrões específicos para Empreendimentos Habitacionais de Interesse Social (Lei no 10.410/2000), assim como em Santa Bárbara há uma lei com parâmetros para loteamentos de Interesse Social (Lei no 3.670/2014), mas ambas também não delimitam uma faixa de renda.

Percebe-se que, dos vinte municípios estudados, apenas dez estabelecem ZEIS nos planos diretores: Americana, Artur Nogueira, Campinas, Cosmópolis, Hortolândia, Itatiba, Morungaba, Pedreira, Santa Bárbara d'Oeste e Vinhedo. Desses dez, apenas Americana apresenta mapa com localização e a descrição do perímetro das ZEIS no texto da lei; outros oito municípios apresentam mapas com a localização delas - Artur Nogueira, Campinas, Hortolândia, Itatiba, Morungaba, Santa Bárbara, Pedreira e Vinhedo, sendo que quatro destes não apresentam a identificação dos dois tipos de ZEIS nos mapas - Hortolândia, Cosmópolis, Pedreira e Santa Bárbara d'Oeste (ver Quadro 1, p. 42).

Em relação à produção de Habitações de Interesse Social, destaca-se que, dos dez municípios que instituíram ZEIS, apenas os municípios de Hortolândia, Itatiba e Campinas realizaram Habitações de Interesse Social nelas (ver Mapa 3, p. 59). Em Campinas, obtevese a informação, na Secretaria de Urbanismo Municipal (SEMURB), de que foi entregue em 2013 o Residencial Sirius ${ }^{48}$, sendo apenas um empreendimento, mas com 2.620 apartamentos. Em Itatiba, entre as 15 ZEIS de indução estabelecidas, em 7 delas há projetos de HIS aprovados ${ }^{49}$ no ano de 2015 . Em Hortolândia, os seguintes conjuntos de

\footnotetext{
${ }^{48}$ Segundo informação da SEMURB, houve outras Habitações de Interesse Social, mas o Residencial Sirius foi o único conjunto realizado em ZEIS. Ele apresenta 2.620 apartamentos, cada um com dois dormitórios, sala, cozinha, banheiro, lavanderia e corredor, numa área total de 41,36 metros quadrados, além de uma vaga na garagem.

${ }^{49}$ Conforme informação da Secretaria de Planejamento e Desenvolvimento de Itatiba, segue o número das ZEIS em que há projeto aprovado no ano de 2015 de HIS (cf. numeração do mapa do plano diretor) e a situação do mesmo: (02) Belgine - projeto aprovado; - (05) Maeda - projeto aprovado, obras em andamento; (06) Luiz Gorgueira - projeto aprovado, obras em andamento; (07) Luiz Gorgueira/ João Agostinho dos Santos - projeto
} 
Interesse Social foram realizados em ZEIS: em 2011 - Jd. Primavera - casas; em 2014 Condomínios Portugal, Espanha e Suíça (2014); e previstos para serem entregue em 2015 Condomínios França e Itália (ver mais informações dos conjuntos na Tabela 12, p. 95). No escopo deste trabalho, são consideradas apenas as ZEIS vazias, ou seja, para a reserva de área para a produção de novas HIS. Alguns municípios, como o exemplo de Americana e Pedreira, utilizaram as ZEIS de regularização, entretanto, a utilização desse tipo de ZEIS não foi considerada (cf. Quadro 1, p. 42).

Em Cosmópolis, embora não haja delimitação de ZEIS em anexo ou no próprio plano diretor, segundo técnico da Prefeitura de Cosmópolis, três empreendimentos foram realizados em ZEIS - Residencial Cosmópolis I e II e Manoel Ferreira de Souza. Quando um empreendedor demonstra interesse em realizar HIS, a Prefeitura altera o zoneamento, transformando a área interessada em ZEIS. Ressalta-se que, embora tenham sido realizadas HIS em ZEIS, elas não foram demarcadas no Quadro 1 (p. 42), por compreender que houve uma inversão no conceito do instrumento, o qual deveria ser utilizado para reservar na cidade áreas bem localizadas para futuras HIS, sendo utilizado simplesmente para possibilitar parâmetros urbanísticos reduzidos ${ }^{50}$ para áreas que já seriam utilizadas para produção HIS ou HMP, visto que, em Cosmópolis, as duas categorias são permitidas em ZEIS. Além disso, as leis específicas que transformam essas áreas em ZEIS não são vinculadas ao plano diretor.

\subsubsection{ZEIS etérea nos Planos Diretores}

Apresentam-se neste item os municípios que contemplam o instrumento Zonas Especiais de Interesse Social (ZEIS) de forma vaga, ou seja, esse instrumento não está claramente definido nos planos diretores ou é estabelecido por outras legislações não vinculadas ao plano diretor. São eles: Holambra, Jaguariúna, Indaiatuba, Paulínia e Sumaré (ver Mapa 3, p. 59). Alguns desses municípios mencionam as ZEIS em seus planos diretores, mas isso de modo não propositivo; outros não mencionam as ZEIS em seus planos, porém esse instrumento é estabelecido, posteriormente, por meio das leis de uso e ocupação do solo.

aprovado; (08) José Edson Seste e Irmãos - projeto aprovado; (10) Amancio Catalano/Antiga Avita/Daniel Monteiro - projeto aprovado, obras em andamento; (13) Família Luvison - projeto aprovado, obras em andamento.

${ }^{50}$ Os parâmetros urbanísticos reduzidos podem ser desde o tamanho, testada e área dos lotes, assim como o total da área construída permitida, o número de pavimentos ou outros itens que definam as características das habitações, possibilitando, assim, a implementação de construções de valores mais baixos. 
O plano diretor de Holambra (LC 183/2007) define zonas de especiais interesses urbanos como "áreas voltadas para a produção e manutenção da habitação que visem o interesse social da população de baixa renda, equipando essas áreas com a infra-estrutura necessária para o processo de urbanização ou reestruturação" (artigo 19, LC 183/2007). Essas zonas são apresentadas como um instrumento no plano, no entanto, não ocorrem de forma propositiva ${ }^{51}$.

No plano diretor de Indaiatuba, o artigo $5^{\circ}$ coloca que o anexo I da lei apresenta a descrição do perímetro urbano de Indaiatuba, cabendo a legislação específica a definição de zonas de uso e critérios para uso e ocupação do solo. Essa legislação específica que regulamentará o uso e ocupação do solo contemplará as Zonas Habitacionais de Interesse Social (ZHIS) e as Zonas de Especial Interesse Social (ZEIS) nas Zonas de Predominância Residencial - ZPR2, voltadas em sua maior parte à população de baixa renda e com regras particulares de parcelamento e uso do solo.

Ressalta-se que o plano diretor de Indaiatuba não apresenta as ZHIS E ZEIS de forma propositiva, não delimitando essas áreas. Dessa forma, não foram demarcados os itens das linhas 6 e 7 do Quadro 4 (p. 65) que se referem à instituição dessas zonas no plano diretor, embora o município tenha criado e delimitado as ZEIS posteriormente, por meio da Lei de Uso e Ocupação do Solo no 10/2010 52 . Segundo informação da Secretaria de Habitação, uma dessas áreas de ZEIS foi utilizada para o projeto Campo Limpo (havia previsão de entrega para 2015).

No plano diretor de Jaguariúna (LC 204/2012), tem-se como uma diretriz o aprimoramento do acesso à moradia, principalmente da população de baixa renda, entretanto, não são criadas, nem mencionadas as Zonas Especiais de Interesse Social no plano diretor, nem em seus anexos, ou quaisquer outras delimitações de áreas para provimento de habitação para a população de baixa renda. A despeito de ser mencionada no plano diretor, a Lei de Uso do Solo de Jaguariúna (Lei Complementar no 97/2004 ${ }^{53}$ )

\footnotetext{
${ }^{51} \mathrm{O}$ artigo 48 do plano diretor de Holambra coloca que "as áreas referentes à política de habitação seguirão as seguintes disposições contidas e visualizadas no mapa". No entanto, após diversos telefonemas à Diretoria de Habitação, foi declarado que o mapa a que se refere o artigo 48 é desconhecido. Os técnicos municipais informaram que o importante para a localização de HIS é o mapa de zoneamento, mas nele também não há a delimitação de áreas definidas como ZEIS.

${ }^{52}$ A Lei Complementar no 10 de 2010 trata do uso e ocupação do Solo de Indaiatuba. Nela estão descritos os perímetros de duas Zonas Especiais de Interesse Social e há uma tabela com os padrões de uso do solo, na qual fica estabelecida para ZEIS uma área mínima de $150 \mathrm{~m}^{2}$ para lotes e testada mínima de 7 metros, além de outros critérios de uso e ocupação. Essa Lei é alterada pela Lei Complementar 21/2013, em cujo mapa podem ser identificadas as duas ZEIS.

${ }^{53}$ A Lei Complementar no 97/2004 é alterada por meio da Lei Complementar no 233 de 2013.
} 
apresenta no mapa do anexo III uma pequena área de ZEIS (não especificada se de indução ou de regularização).

O plano diretor de Paulínia tem como um dos objetivos o acesso à moradia digna, entretanto, não são criadas ZEIS, embora no artigo 64, que trata dos objetivos do zoneamento, coloca-se a instituição das ZEIS entre eles. Observa-se que, em 2012, com a aprovação da Lei de Uso do Solo ${ }^{54}$, as ZEIS são instituídas e suas áreas podem ser visualizadas no mapa do anexo dessa lei.

Em Sumaré, a Habitação de Interesse Social com a qual governo se compromete a aprimorar é definida como destinada à parcela da população com maior "vulnerabilidade social". De forma semelhante às ZEIS, propõem-se no plano diretor as Áreas Especiais de Interesse Social (AEIS), tanto áreas vazias para produção de novas HIS, quanto áreas ocupadas de forma precária. No entanto, essas AEIS não são possíveis de serem localizadas, nem por descrição de perímetro, nem por meio de mapa anexo à lei ${ }^{55}$.

Entre os cinco municípios que citam as ZEIS de forma vaga em seus planos diretores, três deles as estabelecem, posteriormente, por meio das suas leis de uso e ocupação do solo: Indaiatuba, Jaguariúna e Paulínia (ver Quadro 3, p. 55).

Existem leis específicas para regulamentar os projetos habitacionais de interesse social no caso de Campinas e Hortolândia, enquanto nos casos de Itatiba, Pedreira e Santa Bárbara o plano diretor institui o instrumento ZEIS e estabelece alguns parâmetros, porém outros são definidos pelas leis de uso do solo, conforme discutido no item anterior deste trabalho. Diferentemente, nos municípios de Indaiatuba, Jaguariúna e Paulínia, as ZEIS são criadas, posteriormente, por meio de outra legislação, não vinculada ao plano diretor. Dessa forma, classificam-se o instrumento ZEIS desses três municípios como "etéreas" nos planos diretores, pois esses municípios ou mencionam as ZEIS em seus planos e não as estabelecem, ou as estabelecem por meio de outra legislação, que não está vinculada ou é posterior ao plano diretor.

\footnotetext{
${ }^{54}$ A Lei Complementar no 54/2012, que dispõe sobre o parcelamento, uso e ocupação do solo de Paulínia, institui as Zonas Especiais de Interesse Social sem classificá-las (de indução ou de regularização). Entre as zonas do município, essa legislação estabelece os menores parâmetros de ocupação para as áreas de ZEIS: área mínima de $140 \mathrm{~m}^{2}$ e testada mínima de 7 metros para os lotes em ZEIS.

${ }^{55} \mathrm{Na}$ lei de parcelamento, uso e ocupação do solo de Sumaré são estabelecidas as chamadas zonas especiais, mas, pela descrição, não se assemelham às ZEIS aqui tratadas, por não serem específicas para habitação de interesse social (Lei 2.831/1995).
} 
Quadro 3 - Municípios que não instituem ZEIS por meio dos planos diretores

\begin{tabular}{|l|c|c|c|}
\hline \multicolumn{1}{|c|}{ Município } & $\begin{array}{c}\text { ZEIS mencionada no Plano } \\
\text { Diretor, mas não instituída }\end{array}$ & $\begin{array}{c}\text { ZEIS criada na Lei } \\
\text { de Uso do Solo }\end{array}$ & $\begin{array}{c}\text { Lei de uso } \\
\text { do solo }\end{array}$ \\
\hline Holambra & $\mathrm{X}$ & $\mathrm{X}$ & $233 / 2013$ \\
\hline Jaguariúna & $\mathrm{X}$ & $\mathrm{X}$ & $54 / 2012$ \\
\hline Paulínia & $\mathrm{X}^{56}$ & & \\
\hline Sumaré & $\mathrm{X}$ & $\mathrm{X}$ & $10 / 2010$ \\
\hline Indaiatuba & &
\end{tabular}

Fonte: tabela sistematizada pela autora a partir da análise dos planos diretores e das leis de uso e ocupação do solo dos municípios (foram consideradas as leis vigentes em 2014).

\subsubsection{Municípios que não estabelecem ZEIS}

São apresentados neste item os municípios que não utilizaram em seus planos diretores o instrumento ZEIS (Zona Especial de Interesse Social) para destinar áreas habitacionais para a classe de baixa renda - Engenheiro Coelho, Monte Mor, Nova Odessa, Valinhos e Santo Antônio de Posse -, assim como as principais questões habitacionais discutidas nos planos diretores desses municípios (ver Mapa 3, p. 59).

No município de Engenheiro Coelho, observa-se que o plano diretor cria e delimita as chamadas Áreas Especiais de Interesse Habitacional, cujo tamanho mínimo do lote é de 500 $\mathrm{m}^{2}$ e a localização ocorre em áreas rurais, distante da malha urbana estabelecida (cf. mapa de zoneamento do plano diretor). Portanto, essas áreas não correspondem às ZEIS (Zonas Especiais de Interesse Social). Acredita-se que a criação das Áreas Especiais de Interesse Habitacional seja uma forma de regulamentar grandes áreas já loteadas na zona rural do município. Verifica-se, portanto, a inexistência das ZEIS no plano diretor de Engenheiro Coelho (LC 11/2012).

A despeito da criação das ZEIS, na seção III (artigos 94 a 97) do plano diretor de Engenheiro Coelho são abordados os parâmetros para loteamentos de interesse social. Coloca-se que o loteamento, para ser classificado como de interesse social, deve ser submetido à análise pelo corpo técnico da prefeitura, e sendo comprovados os benefícios sociais, o prefeito lhe atribui essa condição por meio de decreto. Permite-se a urbanização de loteamentos de interesse social para a comercialização de lotes e para a implantação de conjuntos de HIS. Os loteamentos de interesse social podem ter lotes com área mínima de $150 \mathrm{~m}^{2}$ e frente de no mínimo 6,00 metros. Os loteamentos e, portanto, os conjuntos habitacionais de interesse social podem ser implantados nas zonas: Zr1, Zr5 e zona mista.

\footnotetext{
${ }^{56}$ No plano diretor de Sumaré, são mencionadas "Áreas Especiais de Interesse Social", cujo conceito assemelhase ao da ZEIS. Por isso, embora o termo ZEIS não seja mencionado no plano diretor, essa coluna foi assinalada na tabela.
} 
Em Monte Mor, o plano diretor (LC 16/2010) tem um capítulo específico destinado à Política de Habitação, no qual se destacam os seguintes objetivos e diretrizes: deve haver diversidade de programas e a ênfase deve ser na habitação de interesse social (HIS); devese promover a ocupação das glebas subutilizadas ou não utilizadas em Zona Urbana; e, ainda, deve haver normas especiais para as HIS. A despeito dessas diretrizes, não é criado nem mencionado o instrumento ZEIS para reservar áreas bem localizadas, dotadas de infraestrutura para a produção de novas HIS.

Ressalta-se que, no inciso V do artigo 20 (LC 16/2010), são definidas as Áreas de Especial Interesse Social (AEIS) como áreas voltadas à "habitação da população de baixa renda", que podem ser áreas ocupadas por assentamentos precários, assim como lotes ou glebas subutilizados ou não utilizados. Embora o termo utilizado seja o mesmo da cidade de Sumaré, no caso de Monte Mor, a nomenclatura AEIS aparece como uma definição geral para todas as áreas voltadas à habitação de baixa renda. As Áreas de Especial Interesse Social não são colocadas de forma propositiva; em nenhum momento cita-se que essas áreas devem ser delimitadas, e de fato não o são, nem no texto nem nos mapas anexos do plano diretor.

O plano diretor de Nova Odessa coloca que a propriedade imobiliária cumpre sua função social ao respeitar a função social da cidade e, ao ser utilizada conforme o estabelecido no plano diretor e compatível, entre outros fatores, com a necessidade de implantar projetos de Habitação de Interesse Social (LC 10/2006, art. 7). A seção I desse plano diretor aborda especificadamente a Política Municipal de Habitação, cujo princípio é facilitar o acesso à moradia, assim como melhorar a qualidade de vida dos moradores, oferecendo condições adequadas de urbanização e infraestrutura. Entre outros, os objetivos dessa política ${ }^{57}$ são: garantir que os projetos de Habitação de Interesse Social (públicos ou privados) sejam implantados em locais com infraestrutura e serviços suficientes considerando a nova demanda; e integrar os programas de habitação à Política de Desenvolvimento Urbano para a garantia da "ocupação racional do solo, a democratização do acesso aos terrenos urbanizados e a otimização dos investimentos públicos" (art. 11,

\footnotetext{
57 Os outros objetivos da política de habitação de Nova Odessa são: incentivar empreendimentos privados para HIS voltados às famílias de baixa renda; reunir esforços públicos e privados para melhorar a qualidade e reduzir os custos da moradia; incentivar a participação da população na proposição, execução e avaliação de projetos habitacionais; adequar os programas e projetos às condições socioeconômicas e aos interesses dos usuários; dar preferência a soluções urbanísticas com menor movimento de terra, para amenizar danos ao meio ambiente e diminuir custos; oferecer o acesso das moradias às redes de infraestrutura; garantir um conjunto de equipamentos sociais e serviços públicos às áreas habitacionais.
} 
inciso V, LC 10/2006). Apesar disso, o plano diretor ${ }^{58}$ não institui as Zonas Especiais de Interesse Social (ZEIS) voltadas para projetos de HIS e não atribui a criação destas a outras legislações municipais.

No Plano Diretor do município de Santo Antônio de Posse (LC 17/2006), não são estabelecidas e nem mencionadas as Zonas Especiais de Interesse Social. No entanto, o inciso III do artigo 41 diz que se deve garantir o acesso à Habitação de Interesse Social em terra urbanizada, em área sem fragilidades ambientais e com infraestrutura adequada, e ainda se coloca que isso deve ser realizado por meio de zoneamento específico com lotes de área mínima de $250 \mathrm{~m}^{2}$ e 10 metros de frente.

No plano diretor de Valinhos (Lei no 3841/2004), coloca-se na seção referente à Habitação as seguintes diretrizes: concentração na erradicação das submoradias, habitações e locais de risco e loteamentos irregulares; atuação junto aos órgãos federais e estaduais e da iniciativa privada para minimizar o déficit habitacional; busca pelo conceito de função social da propriedade urbana nos terrenos localizados na zona urbana de Valinhos. Para tal, são colocadas no artigo $8^{\circ}$ as ações para a área de habitação, destacando: assessorar cooperativas e associações habitacionais; minimizar o déficit habitacional para a população desprovida de moradia na faixa de até 10 salários mínimos (SM), moradores há mais de 3 anos e priorizando a faixa de renda de até 3 SM; viabilizar ações de regularização fundiária e realizar ações para eliminar os "bolsões de pobreza". A despeito de serem mencionadas como ações na área de habitação a regularização fundiária e a redução do déficit, priorizando a população com renda de até 3 salários mínimos, não é criado nem mencionado o instrumento ZEIS ${ }^{59}$ no plano diretor de Valinhos.

Neste ponto, cabe destacar as fragilidades das legislações analisadas. No caso de Engenheiro Coelho, coloca-se como objetivo da política habitacional a distribuição de forma homogênea das habitações de interesse social para evitar os chamados "bolsões de pobreza". No entanto, os loteamentos e conjuntos habitacionais de interesse social devem localizar-se em zonas específicas supracitadas, cujas localizações estão a leste do lago que divide a cidade ou a norte da Rodovia João Tosello, de forma que estejam em locais diferentes e com limites definidos em relação às áreas ocupadas majoritariamente pelas

\footnotetext{
58 O município é dividido nas seguintes zonas (art. 189): Zona Predominantemente Residencial; Zona Mista; Zona Comercial; Faixa Especial; Zona de Produção Industrial; Zona de Interesse Ambiental e Paisagístico; Zona de Produção Agrícola, Turismo e Recreação; Área de Preservação Ambiental. Em 2013, por meio da Lei Complementar 33, altera-se o zoneamento no plano diretor, mas não são instituídas as ZEIS.

${ }^{59}$ A Lei 4.786 de 2007 de Valinhos aborda sobre o uso e ocupação do solo. O artigo 11 lista 19 zonas da cidade, e não são estabelecidas as ZEIS (Zonas Especiais de Interesse Social).
} 
classes de maior poder aquisitivo ${ }^{60}$. Em Valinhos, a despeito da regularização fundiária ser citada como uma ação da área de habitação no plano diretor, não são criadas as ZEIS de regularização.

No caso de Santo Antônio de Posse, Monte Mor e Nova Odessa, embora os planos diretores destaquem a importância de garantir Habitações de Interesse Social em áreas urbanizadas, com infraestrutura, não utilizam o instrumento ZEIS para de fato garantir a reserva dessas áreas bem localizadas. Nem as Leis de Uso do Solo ${ }^{61}$ de Santo Antônio de Posse (2010) e de Monte Mor (2010), nem a alteração do zoneamento do plano diretor de Nova Odessa ${ }^{62}$ de 2013 cria zonas específicas para as Habitações de Interesse Social.

\subsubsection{Análise do instrumento ZEIS nos planos diretores da RMC}

As Zonas Especiais de Interesse Social, ao serem conformadas como o instrumento urbanístico que permite reservar na cidade áreas para moradia às populações de baixa renda bem localizadas e com acesso aos serviços urbanos, já cumprem parte do que seria uma habitação qualificada. Segundo Rolnik e Santoro (2013), as ZEIS poderiam ser consideradas como uma forma de "zoneamento includente", cuja definição seria normas ou leis que obrigam ou estimulam empreendedores privados a oferecerem Habitações de Interesse Social, aprimorando a produção para uma população que ficaria excluída do mercado, ao menos naquelas áreas bem localizadas.

A partir dos dados levantados nos planos diretores dos municípios da RMC, torna-se evidente que, ao abordar o instrumento ZEIS em uma mesma região metropolitana, tem-se uma diversidade de significados e de parâmetros urbanísticos. Percebe-se a fragilidade do instrumento, muitas vezes sujeito a interpretações nesses municípios. As ZEIS são áreas voltadas à Habitação de Interesse Social cuja destinação altera conforme o município. Alguns municípios as instituem para famílias com renda de 0 a 3 salários mínimos; outros consideram uma faixa de até 10 salários mínimos; outros ainda sequer definem uma faixa de renda, embora incentivem a produção de HIS. Verifica-se que, em alguns casos, são produzidas unidades habitacionais não para as famílias de baixa renda, mas para a classe média baixa. Dessa forma, os parâmetros urbanísticos reduzidos, permitidos nas HIS, não

\footnotetext{
${ }^{60}$ Após entrevista com técnicos municipais e observação das tipologias habitacionais e do tamanho dos lotes, verificou-se que área central e as zonas residenciais 2, 3 e 4 são ocupadas predominantemente pelas classes de maior poder aquisitivo.

${ }^{61}$ Lei Complementar de Santo Antônio de Posse no 16 de 2010 e Lei Complementar no 17 de 2010 de Monte Mor (ver referências bibliográficas).

62 Lei Complementar de Nova Odessa nº 33 de 2013.
} 
são utilizados para produzir unidades mais baratas, mas para que empreendedores privados tenham um lucro maior. Percebe-se, portanto, que uma legislação que permite parâmetros diferenciados para as HIS, mas não as define com clareza, acaba sendo deturpada, muitas vezes favorecendo mais o mercado imobiliário do que a população de baixa renda.

Entre os municípios da RMC, foi possível identificar três grupos: aqueles que não instituem as ZEIS, aqueles que mencionam as ZEIS de forma vaga e aqueles que não as instituíram, conforme se pode observar no mapa a seguir.

\section{Mapa 3 - Municípios da RMC quanto à instituição de ZEIS (nos planos diretores)}

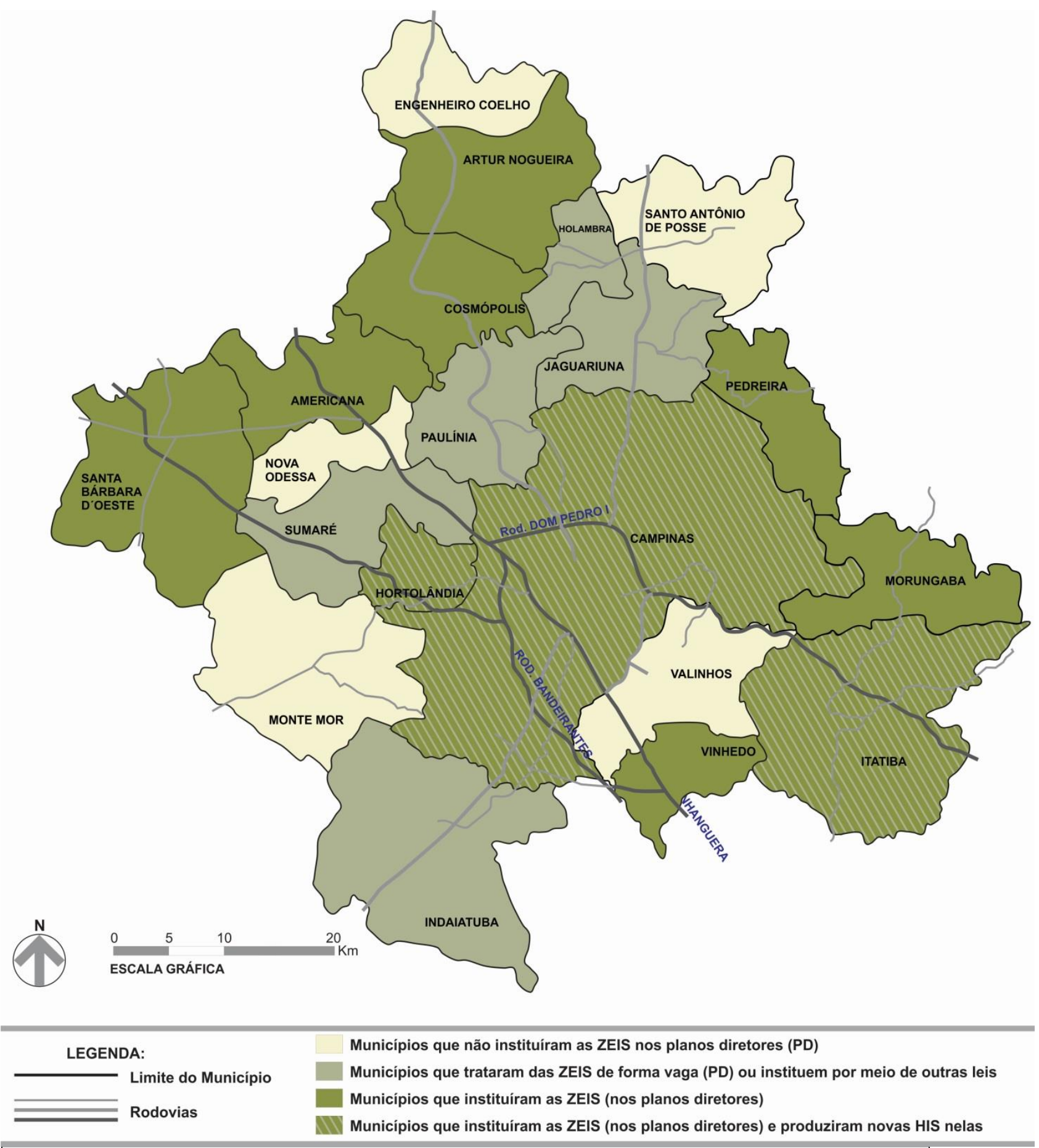

Fonte do mapa: identificação dos municípios realizada pela autora a partir da análise dos planos diretores (vigentes em 2014) da RMC. 
Destaca-se aqui que, dos vinte municípios da Região Metropolitana de Campinas, apenas metade instituem as ZEIS; entre estes, nove municípios apresentam a localização delas, e deles, apenas três realizaram Habitações de Interesse Social nessas "reservas" de área (cf. Mapa 3, p. 59). Ressaltam-se, ainda, dois casos: o primeiro, do município de Americana, onde são demarcadas as ZEIS, mas o proprietário da área pode desafetá-la de ZEIS mediante alguns procedimentos; o segundo, do município de Cosmópolis, onde o conceito de ZEIS é inverso, pois as áreas não são demarcadas antecipadamente para reservar áreas bem localizadas na cidade às classes de mais baixa renda, e as ZEIS são delimitadas posteriormente, conforme interesse do mercado imobiliário.

Percebe-se, portanto, que os parâmetros voltados às Habitações de Interesse Social são muitas vezes utilizados com outras finalidades. As demarcações de Zonas Especiais de Interesse Social são difíceis de serem observadas na RMC, e quando ocorrem, ainda há formas de reversão, como se observa em Americana; não foram localizadas em mapas as ZEIS em todos os casos em que foram instituídas; dos municípios que instituíram e localizaram ZEIS, apenas três utilizaram essas áreas para produção de Habitações de Interesse Social; o conceito do instrumento ZEIS pode ser deturpado, não sendo utilizado para reservar áreas para produção de HIS, mas para possibilitar parâmetros reduzidos, ou seja, maior lucro, em áreas eleitas pelos empreendedores.

Assim como as cidades são objetos de conflito de classes, suas leis, seus planos diretores e também os instrumentos urbanísticos o são. Inserir ZEIS nos planos diretores municipais para reservar áreas bem localizadas à população de baixa renda é sempre uma luta social ${ }^{63}$. Talvez por isso, muitas vezes tais ZEIS são mencionadas nos planos, porém, são apenas parcialmente definidas, permitindo alterações "segundo a conveniência". Não se pretende aqui demonstrar ou discutir esses conflitos sociais, mas é importante que os dados apresentados não sejam entendidos de forma desvinculada ao contexto de disputa social (MARICATO, 1995, 2011b, 2011c; FERREIRA, 2003; VILLAÇA, 1999 e 2005).

\subsubsection{A Diversidade de Instrumentos Urbanísticos voltados à Habitação de Interesse Social na RMC}

A seguir, apresenta-se uma tabela síntese dos planos diretores da Região Metropolitana de Campinas (RMC), com os principais instrumentos urbanísticos colocados

\footnotetext{
${ }^{63}$ Cabe destacar a forte presença da luta social na região de Campinas: o MTST (Movimento dos Trabalhadores Sem Teto) tem sua origem em 1997, a partir de reuniões temporárias na ocupação do Parque Oziel em Campinas. Posteriormente, têm-se diversas ocupações na região: Frei Tito em Campinas (2007), Zumbi dos Palmares, em Sumaré e Dandara em Hortolândia (2008) (DAL'BÓ, 2013, p. 24 e 25).
} 
com o Estatuto da Cidade voltados à Habitação de Interesse Social (HIS): Zonas Especiais de Interesse Social (ZEIS), outorga onerosa, transferência do direito de construir, direito de preempção, disponibilização de assistência técnica, jurídica e social, Estudo de Impacto de Vizinhança, consórcio imobiliário e operação urbana consorciada. Destaca-se que nos planos diretores constam outros instrumentos, e não apenas os citados no Quadro 4 (p. 65), mas nela estão relacionados aqueles que, no texto dos planos diretores dos municípios da RMC, trataram especificadamente da problemática habitacional.

Observa-se no Quadro 4 (p. 65) que os instrumentos utilizados nos planos diretores por mais da metade dos municípios da Região Metropolitana de Campinas para a questão habitacional são: transferência do direito de construir para fins de regularização fundiária e de HIS, direito de preempção para a produção de Habitação de Interesse Social (HIS) e a instituição das ZEIS, discutida no item 2.1.1 (p. 40) deste trabalho.

O direito de preempção, que se define como o direito de preferência do poder público para compra de determinadas áreas da cidade, pode ser fundamental para a implementação de novas HIS. No entanto, embora esse tenha sido o instrumento mais empregado nos planos dos municípios da RMC (13 municípios), isso não significa que ele tenha sido de fato utilizado, pois muitas vezes o município cita o instrumento, mas não demarca quais são as áreas sobre as quais ele deve incidir. Além disso, demarcaram-se na tabela os municípios que citaram que o direito de preempção pode ser exercido para produção de HIS, mas ele também pode ser utilizado para outras finalidades, definidas nos planos diretores.

Outro instrumento também bastante recorrente nos municípios da RMC foi a transferência do direito de construir, por meio do qual o poder público pode demarcar áreas onde há o interesse em manter uma baixa densidade, definindo que os proprietários daquelas áreas devem exercer seu potencial construtivo em outro local ou vendê-lo a outro proprietário. Ressalta-se, ainda, que esse instrumento associado às ZEIS pode possibilitar soluções interessantes para áreas de conflitos de terras. Estão marcados no Quadro 4 (p. 65) os municípios que descreveram nos planos que essa transferência pode ser utilizada para fins de regularização fundiária e de produção de HIS. Pode-se perceber que, dos onze municípios que utilizaram a transferência do direito de construir, apenas seis também instituíram as ZEIS.

Outra ferramenta importante, que pode ser associada às duas acima, é a disponibilização de assistência técnica e jurídica para a população nos casos de regularização fundiária, que está presente no texto de nove dos vinte municípios da RMC (Quadro 4, p. 65). No entanto, quando se observa quais municípios apresentam a instituição das ZEIS, a 
transferência do direito de construir para regularização fundiária e a disponibilização de assistência técnica e jurídica, sobre a possibilidade de associar esses instrumentos, há apenas quatro municípios: Artur Nogueira, Itatiba, Morungaba e Pedreira.

A outorga onerosa é o instrumento que permite ao poder público conceder ao proprietário que ele construa acima do coeficiente de aproveitamento básico ${ }^{64}$ mediante contrapartida financeira. O plano diretor municipal deve determinar as áreas onde podem incidir a outorga onerosa, os valores de coeficiente básico e coeficiente máximo. Destacamse no Quadro 4 (p. 65) dois casos: o primeiro, quando o município estabelece que os recursos oriundos da outorga onerosa são geridos pelo fundo municipal de Habitação (4 municípios); o segundo, quando está explícito no texto do plano diretor que esses recursos podem ser utilizados para produção de HIS (3 casos).

O Estudo de Impacto de Vizinhança (EIV) é um instrumento trazido pelo Estatuto que permite avaliar melhor os impactos gerados pela implantação de um novo empreendimento; todo imóvel interfere no seu entorno, podendo incidir na vida e na dinâmica urbana. Deve-se determinar quais empreendimentos necessitarão de um EIV, que deverá tratar de questões como o impacto sobre o tráfego, na sobrecarga de infraestrutura, no adensamento populacional, no sombreamento e na poluição sonora. Ressaltam-se, na Região Metropolitana de Campinas, três casos interessantes onde o EIV pode determinar que um percentual de HIS deve ser construído, o que ocorre nos planos diretores de Cosmópolis, Morungaba e Vinhedo (cf. Quadro 4, p. 65).

A seguir, apresentam-se os dois últimos instrumentos analisados nos planos diretores da RMC, ferramentas importantes que podem ser utilizadas para a produção de novas HIS. Por outro lado, eles representam parcerias entre o poder público e a iniciativa privada e, muitas vezes, devido aos interesses de mercado, acabam por beneficiar mais um setor específico ou uma determinada área do que a cidade como um todo.

A operação urbana consorciada é uma intervenção pontual realizada sob coordenação do poder público e com a participação da iniciativa privada e de moradores, com a intenção de realizar mudanças urbanísticas e estruturais, que podem requalificar e valorizar determinada área. O poder público deve determinar a(s) área(s) para operação urbana e elaborar um plano contendo a infraestrutura, distribuição de usos, densidades permitidas,

\footnotetext{
${ }^{64} \mathrm{O}$ Coeficiente de Aproveitamento Básico é um índice que demonstra o quanto pode ser construído no lote. Esse valor em geral é igual a 1, que significa que o proprietário pode construir uma área igual a área do lote. Para 0 proprietário poder edificar uma área maior, ele pode comprar o direito de construir (outorga onerosa), mas quando isso ocorre, o valor não pode ser maior que o coeficiente máximo permitido. Por exemplo, se um lote possui uma área de $100 \mathrm{~m}^{2}$ e o coeficiente básico é 1, pode-se construir $100 \mathrm{~m}^{2}$, e se área tiver um coeficiente máximo de 2,5, significa que se pode comprar o direito de construir mais $150 \mathrm{~m}^{2}$.
} 
padrões de acessibilidade, entre outros. No Quadro 4 (p. 65), destacam-se nove municípios da RMC que colocaram em seus planos que as operações urbanas têm como um dos objetivos a produção de HIS.

O consórcio imobiliário é o instrumento de cooperação entre o poder público e a iniciativa privada por meio do qual é possível realizar a transferência de imóvel do proprietário ao poder público municipal, para que o mesmo realize obras e o proprietário receba como pagamento parte da área devidamente urbanizada ou edificada. O consórcio deve ser utilizado para viabilizar o uso de imóveis que não cumprem a sua função social, em áreas que tenham carência de infraestrutura e serviços urbanos e tenham imóveis não utilizados ou subutilizados. No Quadro 4 (p. 65), pode-se perceber o caso do município de Hortolândia, que dispõe que o instrumento consórcio imobiliário pode ser aplicado em área de ZEIS, além de outros cinco municípios da RMC que mencionam em seus planos diretores a utilização do consórcio imobiliário para viabilização da produção de HIS.

Ressalta-se que a instituição de instrumentos nos planos diretores para a produção de Habitação de Interesse Social não significa que eles foram utilizados ou que houve uma maior produção de HIS. Esta discussão é para compreender quais instrumentos do Estatuto da Cidade estão sendo utilizados nos municípios da Região Metropolitana de Campinas. Pretende-se, além da apresentação dos instrumentos acima, identificar grupos de municípios conforme a disponibilidade de instrumentos voltados à produção de HIS nos planos diretores (vigentes em 2014).

Primeiramente, pode-se notar um grupo de sete municípios (grupo A) - Artur Nogueira, Cosmópolis, Hortolândia, Itatiba, Morungaba, Pedreira e Vinhedo - que apresentam em seus planos diretores uma grande quantidade de instrumentos voltados à HIS. Ressalta-se que, nesse grupo, mais da metade dos municípios apresentou um título ou capítulo específico no plano diretor para discutir Habitação, todos eles utilizaram os instrumentos ZEIS e direito de preempção, e outros instrumentos bastante recorrentes foram a transferência do direito de construir, a disponibilização de assistência técnica e jurídica para regularização fundiária e a operação urbana consorciada. Nesse conjunto de municípios, Itatiba e Morungaba apresentaram o maior número de instrumentos para HIS, a despeito de escalas tão díspares.

É possível identificar um segundo grupo intermediário, de seis municípios (grupo B) Americana, Campinas, Nova Odessa, Santa Bárbara d'Oeste, Sumaré e Valinhos - que apresentam alguns instrumentos para HIS, sendo que, destes, apenas metade institui as ZEIS. Aqui há municípios com grande número populacional e outros de porte intermediário, 
de modo que não é possível fazer uma relação direta entre estrutura técnico-administrativa e a quantidade de instrumentos voltados à HIS. Embora caiba lembrar que a discriminação desses grupos é um esforço metodológico de compreender os aparatos urbanísticos apresentados nos planos diretores dos municípios da RMC, mas que há especificidades nos planos de cada um.

Há um terceiro grupo, de sete municípios (grupo C) - Engenheiro Coelho, Holambra, Indaiatuba, Jaguariúna, Monte Mor, Paulínia e Santo Antônio de Posse - que não apresentam instrumentos para produção de HIS ou apresentam pouquíssimos deles (ver Quadro 4, p. 65). Destaca-se que esses sete municípios não instituíram as ZEIS, o instrumento de aplicação mais comum para HIS (ver Mapa 4, p. 64 e Mapa 3, p. 59).

Mapa 4 - Municípios conforme a quantidade de instrumentos para HIS em seus planos diretores

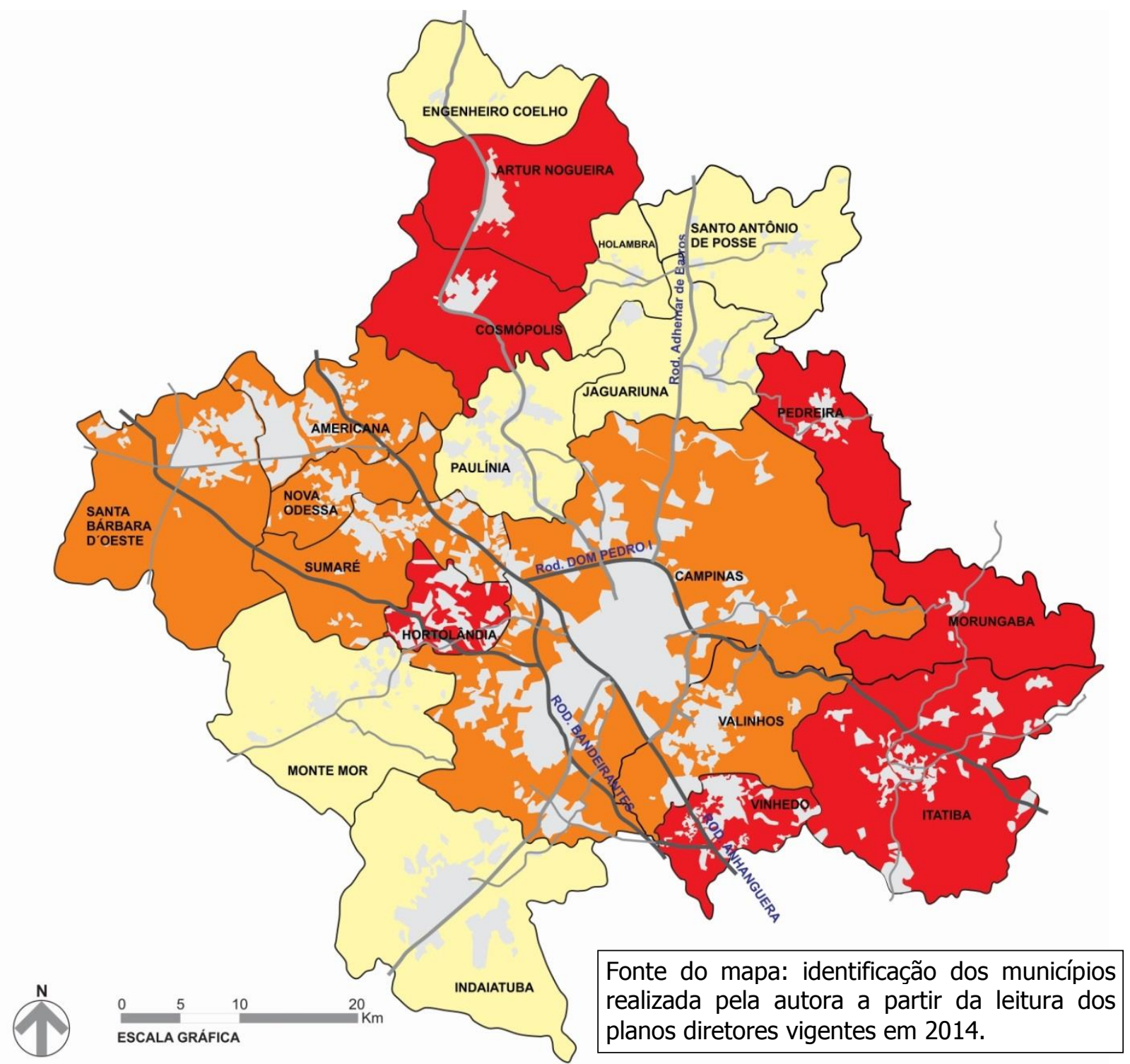


Quadro 4 - Planos diretores (vigentes em 2014) e sua relação com Habitação de Interesse Social

\begin{tabular}{|c|c|c|c|c|c|c|c|c|c|c|c|c|c|c|c|c|c|c|c|c|}
\hline $\begin{array}{c}\text { Destacam-se a existência destes itens nos Planos } \\
\text { Diretores Municipais: }\end{array}$ & 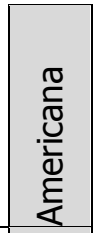 & 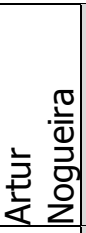 & 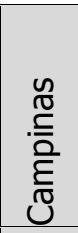 & 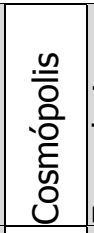 & 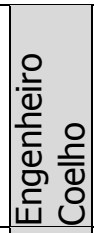 & 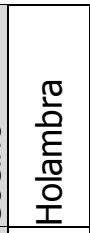 & 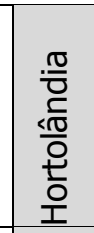 & $\begin{array}{l}\frac{\pi}{0} \\
\frac{0}{2} \\
. \frac{\pi}{\pi} \\
\frac{\pi}{0} \\
\frac{\sigma}{1}\end{array}$ & 惫 & 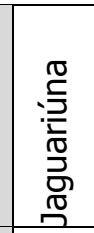 & $\begin{array}{l}\sum_{\Sigma}^{\circ} \\
\Phi \\
\stackrel{\nu}{0} \\
\Sigma \\
\Sigma\end{array}$ & 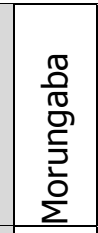 & $\begin{array}{l}\mathbb{0} \\
0 \\
0 \\
0 \\
0 \\
0 \\
0 \\
0 \\
2\end{array}$ & 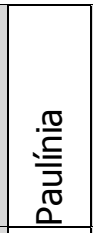 & 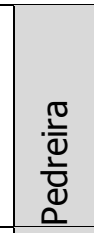 & 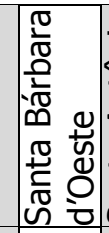 & 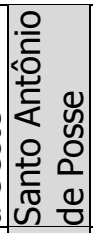 & 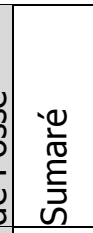 & 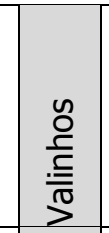 & $\begin{array}{l}\frac{}{0} \\
\frac{d}{5} \\
\stackrel{5}{5}\end{array}$ \\
\hline o do Plano Diretor & 2008 & 2007 & 2006 & 2007 & 2012 & 2007 & 2008 & 32010 & 2011 & 2012 & 2010 & 2006 & 62006 & 2006 & 52008 & 82006 & 2006 & 52006 & 62004 & 2007 \\
\hline ulo ou capítulo específico de Habitação & $\mathbf{X}$ & $\mathbf{X}$ & $\mathbf{X}$ & & & $\mathbf{X}$ & $\mathbf{x}$ & & & & $\mathbf{x}$ & $\mathbf{X}$ & & & $\mathbf{X}$ & $\mathbf{x}$ & $\mathbf{X}$ & & $\mathbf{x}$ & $\mathbf{X}$ \\
\hline $\begin{array}{l}\text { põe parceria com Estado e/ou governo federal para } \\
\text { dução de HIS }\end{array}$ & $\mathbf{X}$ & $\mathbf{X}$ & $\mathbf{x}$ & $\mathbf{X}$ & $\mathbf{x}$ & & & & $\mathbf{X}$ & $\mathbf{X}$ & $\mathbf{x}$ & & & $\mathbf{x}$ & $\mathbf{X}$ & $\mathbf{X}$ & & $\mathbf{x}$ & & \\
\hline opõe a criação de ZEIS para HIS de regularização & $\mathbf{x}$ & $\mathbf{x}$ & $\mathbf{x}$ & $\mathbf{x}$ & & & $\mathbf{x}$ & & $\mathbf{x}$ & & & & & & & & & & & $\mathbf{X}$ \\
\hline põe a criação de ZEIS para HIS de indução & $\mathbf{x}$ & $\mathbf{x}$ & $\mathbf{x}$ & $\mathbf{x}$ & & & $\mathbf{x}$ & & $\mathbf{x}$ & & & & & & & & & & & $\mathbf{X}$ \\
\hline $\begin{array}{l}\text { cursos de outorga onerosa geridos pelo Fundo } \\
\text { Inicipal de Habitação }\end{array}$ & $\mathbf{X}$ & & & & & & $\mathbf{X}$ & & $\mathbf{X}$ & & & & & & & & & $\mathbf{X}$ & & \\
\hline $\begin{array}{l}\text { cursos de outorga onerosa destinados à produção de } \\
\text { bitação de Interesse Social }\end{array}$ & & $\mathbf{X}$ & & & & & & & $\mathbf{x}$ & & & & & & $\mathbf{X}$ & & & & & \\
\hline $\begin{array}{l}\text { ansferência do direito de construir para fins de } \\
\text { gularização fundiária }\end{array}$ & & $\mathbf{X}$ & $\mathbf{x}$ & & & & & $\mathbf{X}$ & $\mathbf{x}$ & $\mathbf{x}$ & & $\mathbf{x}$ & $\mathbf{x}$ & & $\mathbf{x}$ & $\mathbf{X}$ & & $\mathbf{x}$ & $\mathbf{X}$ & \\
\hline $\begin{array}{l}\text { tudo de Impacto de Vizinhança pode determinar que } \\
\text { p percentual de HIS deve ser construído }\end{array}$ & & & & $\mathbf{x}$ & & & & & & & & $\mathbf{X}$ & & & & & & & & $\mathbf{X}$ \\
\hline $\begin{array}{l}\text { nsórcio imobiliário para viabilizar empreendimentos de } \\
\text { eresse social }\end{array}$ & & & & & $\mathbf{X}$ & & $\mathbf{X}$ & & & & & $\mathbf{X}$ & & & & & & $\mathbf{x}$ & & $\mathbf{X}$ \\
\hline nsórcio imobiliário pode ser aplicado às áreas de ZEIS & & & & & & & $\mathbf{x}$ & & & & & & & & & & & & & \\
\hline $\begin{array}{l}\text { eração urbana consorciada tem como um dos } \\
\text { jetivos a produção de HIS }\end{array}$ & & & $\mathbf{X}$ & $\mathbf{X}$ & & & & & $\mathbf{X}$ & & & $\mathbf{x}$ & $\mathbf{x}$ & & $\mathbf{x}$ & & & $\mathbf{X}$ & $\mathbf{x}$ & $\mathbf{x}$ \\
\hline
\end{tabular}

Fonte: análise desenvolvida pela autora a partir da leitura dos planos diretores dos municípios da Região Metropolitana de Campinas (ver cada legislação em Referências Bibliográficas, p. 172). Considerou-se a metodologia apresentada no artigo de Silva, J. (2011a). 
Na tabela anterior, apesar da compreensão das especificidades de cada legislação, houve o esforço de sistematizar as informações referentes à Habitação de Interesse Social para a comparação entre os municípios. Para leitura das informações das tabelas, cabem algumas ressalvas:

a) Em relação à Znona Especial de Interesse Social (ZEIS), se o município criou uma área específica para produção de Habitação de Interesse Social, mesmo que os termos utilizados não sejam exatamente ZEIS, eles foram demarcados no Quadro 4 (p. 65) e no Quadro 1 (p. 42).

b) As Zonas Especiais de Interesse Social foram divididas em de regularização e de indução. Ressalta-se que nem todos os municípios utilizam essa nomenclatura específica, mas quando os conceitos são semelhantes, mesmo que o município utilize nomenclatura diversa, no Quadro 4 e no Quadro 1 (p. 42) eles foram unificados.

c) Quanto à transferência do direito de construir e ao direito de preempção, foram demarcados apenas os municípios que declararam no texto da lei do plano diretor que esses instrumentos podem ser utilizados para fins de regularização fundiária ou para produção de HIS. Alguns municípios citam o instrumento, mas não o relacionam diretamente com a produção de Habitação de Interesse Social ou regularização fundiária. Assim, eles não foram demarcados na tabela acima.

d) Da mesma forma, apenas estão demarcados os municípios que citam no texto da lei que podem utilizar o direito de preempção para estabelecer áreas para Habitação de Interesse Social. Quando o instrumento é mencionado para cumprir a função social da propriedade, mas não cita sua relação direta com projetos de HIS, os municípios que adotam essa direção não foram demarcados no Quadro 4 (p. 65).

e) $O$ instrumento Estudo de Impacto de Vizinhança (EIV) consta em diversos planos diretores, para avaliar a qualidade e possíveis problemas dos empreendimentos, inclusive habitacionais. No entanto, apenas constam no Quadro 4 (p. 65) os municípios que relacionam tal estudo à possível necessidade de construção de Habitações de Interesse Social, no próprio projeto ou vinculadas a ele.

\subsection{Leis de Fundo, Conselho e Plano Habitacional | Municípios da RMC}

Com a aprovação do Sistema e Fundo Nacionais de Habitação de Interesse Social (SNHIS) em 2005, estabelecem-se algumas normas para obtenção de recursos federais pelos 
municípios para habitação de interesse social: a constituição de fundo, de conselho e de formulação de plano habitacional. Essas condições estão definidas nos incisos de I a III do artigo 12 da Lei Federal 11.124/2005.

Considerando a importância da integração entre as diferentes instâncias de governo para políticas habitacionais, realizou-se o levantamento dos municípios que possuem as três condições para obtenção de recursos federais na Região Metropolitana de Campinas (ver: Quadro 5, p. 68 e Mapa 5, p. 71). Lembrando que possuir fundo, conselho e plano local de habitação não significa que foram obtidos recursos federais pelo município, mas que o município possui os parâmetros mínimos para os solicitar.

Deve-se, ainda, discutir a importância dos três itens colocados pelo governo federal se eles garantem de fato uma melhor aplicação dos recursos federais ou se eles se tornaram meramente burocráticos. Pois alguns desses planos, como no caso de Santo Antônio, são simplificados, sem análises ou mapeamento das situações habitacionais municipais. Não cabe no escopo deste trabalho uma discussão minuciosa acerca das leis de fundo e conselho e PLHIS de todos os municípios, mas, de forma semelhante ao que se pode perceber na análise dos planos diretores, há grandes diferenças entre os PLHIS dos municípios da RMC, o que reflete a estrutura técnico-administrativa dos municípios.

O levantamento das leis de fundo, conselho e PLHIS foi realizado em 2013, com atualizações em 2014 e 2015, por meio dos sites das Prefeituras, bibliotecas jurídicas municipais e via telefone. Para obtenção das informações de Artur Nogueira, Cosmópolis, Holambra e Monte Mor, houve pesquisa via telefone. Em Pedreira, Santo Antônio de Posse e Hortolândia, houve visita para obtenção das informações sobre o PLHIS. São considerados, portanto, todas as leis e planos aprovados até 2014. Os arquivos levantados estão disponíveis no Anexo I - "Coletânea das Regulamentações Municipais da RMC", p. 209.

Esses levantamentos, juntamente com as regulamentações e orientações colocadas pelos planos diretores, permitem visualizar um panorama da instrumentalização dos municípios perante a questão habitacional. A seguir, apresenta-se um quadro com os números das leis de fundo, de conselho e plano local de habitação de interesse social (PLHIS) dos municípios da RMC. Na última coluna do quadro, constam alterações dessas legislações ou mesmo outras legislações habitacionais que pareceram importantes no decorrer do levantamento. 
Quadro 5 - Leis de Fundo, Conselho e Plano Local de Habitação dos municípios da Região Metropolitana de Campinas.

\begin{tabular}{|c|c|c|c|c|c|c|c|c|}
\hline \multirow{2}{*}{ Municípios } & \multicolumn{2}{|c|}{$\begin{array}{l}\text { FUNDO DE } \\
\text { HABITACÃO }\end{array}$} & \multicolumn{2}{|c|}{$\begin{array}{l}\text { CONSELHO DE } \\
\text { HABITAÇÃO }\end{array}$} & \multicolumn{3}{|c|}{ PLANO LOCAL DE HABITAÇÃO | PLHIS } & \multirow{2}{*}{$\begin{array}{l}\text { Alterações nas legislações / leis } \\
\text { complementares ou outras observações }\end{array}$} \\
\hline & Lei $\left(n^{0}\right)$ & Data & Lei $\left(n^{0}\right)$ & Data & Existência & Data & Observações & \\
\hline Americana & Lei 4.196 & 2005 & Lei 4.196 & 2005 & Tem PLHIS & $\begin{array}{l}2008 \\
(\mathrm{Dez})\end{array} \mid$ & & $\begin{array}{l}\text { As Leis } 4.413 / 2008 \text { e } 4.731 / 2008 \text { alteram a Lei } \\
4196 / 2005 \text { (art. } 21) \text {. } \\
\text { A composição do Conselho é alterada pelos } \\
\text { Decretos 9.853/2012 e 9.147/2011. A Lei } \\
4.632 / 2008 \text { acrescenta sobre o Fundo municipal } \\
\text { de Habitação. }\end{array}$ \\
\hline $\begin{array}{l}\text { Artur } \\
\text { Nogueira }\end{array}$ & Lei 2.959 & 2009 & Lei 2.959 & 2009 & NÃO TEM & & $\begin{array}{l}\text { Conforme informação obtida por } \\
\text { telefone em 01/2016, o município não } \\
\text { possui PLHIS. }\end{array}$ & \\
\hline Campinas & $\begin{array}{l}\text { Lei } \\
10.616\end{array}$ & 2000 & $\begin{array}{l}\text { Lei } 11.464 \\
\text { Dec } \\
14.225 \\
\text { Dec } \\
14.428\end{array}$ & 2003 & Tem PLHIS & $\left|\begin{array}{l}2011 \\
\text { (Ago) }\end{array}\right|$ & & $\begin{array}{l}\text { A Lei Municipal } 14.901 / 2004 \text { de Campinas } \\
\text { estabelece normas operacionais relativas à } \\
\text { execução orçamentária e financeira do Fundo } \\
\text { Municipal de Habitação. } \\
\text { A Lei Municipal } 11.464 / 2003 \text { cria o Conselho } \\
\text { Municipal de Habitação, o Decreto } 14.225 / 2003 \\
\text { institui o mesmo e o Decreto } 14.428 / 2003 \\
\text { dispõe sobre o regimento do Conselho. } \\
\end{array}$ \\
\hline Cosmópolis & Lei 3.010 & 2008 & Lei 3.010 & 2008 & Possui & 2012 & & $\begin{array}{l}\text { As Leis Municipais } n^{0} 3.074 / 2008 \text { e } 3.534 / 2013 \\
\text { alteram a Lei } 3.010 / 2008, \text { acrescentando ao } \\
\text { Conselho Municipal der Habitação, } \\
\text { respectivamente, membros da associação de } \\
\text { moradores de bairros e um membro da } \\
\text { Associação dos Produtores Rurais de Cosmópolis } \\
\text { (APRUC). }\end{array}$ \\
\hline Eng. Coelho & NÃO TEM & & NÃO TEM & & NÃO TEM & & $\begin{array}{l}\text { A informação sobre a inexistência de leis } \\
\text { de fundo, de conselho e de PLHIS foi } \\
\text { confirmada em março de } 2015 \text { por } \\
\text { técnico da Prefeitura Municipal. }\end{array}$ & \\
\hline Holambra & Lei 732 & 2011 & Lei 732 & 2011 & NÃO TEM & & $\begin{array}{l}\text { A informação sobre a inexistência do } \\
\text { PLHIS foi obtida em visita ao município } \\
\text { em abril de } 2014 \text { e confirmada por e- } \\
\text { mail em 02/2016. }\end{array}$ & $\begin{array}{l}\text { As Leis anteriores que regulamentavam o Fundo } \\
\text { e o Conselho de Habitação eram, } \\
\text { respectivamente, a Lei } 328 / 00 \text { e a Lei } 327 / 2000 .\end{array}$ \\
\hline
\end{tabular}




\begin{tabular}{|c|c|c|c|c|c|c|c|c|}
\hline \multirow[t]{2}{*}{ Municípios } & \multicolumn{2}{|c|}{$\begin{array}{c}\text { FUNDO DE } \\
\text { HABITAÇÃOO }\end{array}$} & \multicolumn{2}{|c|}{$\begin{array}{l}\text { CONSELHO DE } \\
\text { HABITAÇÃO }\end{array}$} & \multicolumn{3}{|c|}{ PLANO LOCAL DE HABITAÇÃO | PLHIS } & \multirow{2}{*}{$\begin{array}{l}\text { Alterações nas legislações / leis } \\
\text { complementares ou outras observações }\end{array}$} \\
\hline & Lei $\left(n^{0}\right)$ & Data & Lei $\left(n^{0}\right)$ & Data & Existência & Data & Observações & \\
\hline Hortolândia & Lei 1.592 & 2005 & Lei 1.592 & 2005 & NÃO TEM & & $\begin{array}{l}\text { Foi aberto um protocolo na Prefeitura de } \\
\text { Hortolândia (no 020722), em } 2014 \text { por } \\
\text { meio do qual se solicitou o PLHIS. Em } \\
\text { maio de } 2015 \text { obteve-se a informação } \\
\text { (da Secretaria de Habitação) de que o } \\
\text { PLHIS ainda não havia sido enviado para } \\
\text { aprovação da Câmara Municipal de } \\
\text { Hortolândia. Portanto, não há PLHIS } \\
\text { aprovado, ao considerar a data do } \\
\text { levantamento (2014). }\end{array}$ & $\begin{array}{l}\text { O Fundo de Habitação é criado pela Lei } \mathrm{n}^{\circ} \\
1.592 \text { de } 2005 \text { e alterado pela Lei } 1.972 / 2007 \text {. } \\
\text { O Regimento do Conselho Municipal de } \\
\text { Hortolândia é regulamentado pelo Decreto } \\
\text { Municipal no } 2.165 / 2009 \text { e a sua composição é } \\
\text { alterada pela Lei municipal no } 2.561 / 2011 \text {. Por } \\
\text { meio da Lei } 1.883 / 2007 \text {, é revogada a } \\
\text { obrigatoriedade do Conselho de Habitação de } \\
\text { convocar a Conferência Municipal de Habitação } \\
\text { a cada dois anos. }\end{array}$ \\
\hline Indaiatuba & Lei 3.919 & 2000 & Lei 3.919 & 2000 & Tem PLHIS & 2011 & & $\begin{array}{l}\text { A Lei Municipal de Indaiatuba no } 3.919 / 2000 \text { é } \\
\text { alterada e acrescida pelas Leis 5175/2007 e } \\
5.261 / 2007 \text {. }\end{array}$ \\
\hline Itatiba & Lei 4.119 & 2008 & Lei 4.119 & 2008 & Tem PLHIS & 2012 & & $\begin{array}{l}\text { A composição do Conselho Municipal de } \\
\text { Habitação de Itatiba é estabelecida pelo Dec. No } \\
6.006 \text { de } 2011 ; \text { já o regimento do Conselho é } \\
\text { regulamentado pelo Decreto no } 5.696 \text { de } 2009 \text {. } \\
\text { A Lei } 5.826 / 2010 \text { dispõe sobre a substituição de } \\
\text { membros do conselho e a 5.668/2009 sobre a } \\
\text { composição do conselho. A Lei } 4551 \text { de } 2013 \\
\text { altera a Lei } 4.119 / 2012 \text {. }\end{array}$ \\
\hline Jaguariúna & Lei 1.498 & 2003 & Lei 1.498 & 2003 & Tem PLHIS & $\begin{array}{l}2011 \\
(\text { Dez })\end{array}$ & & $\begin{array}{l}\text { Alterações no Conselho Gestor por meio das } \\
\text { Leis n } 1.886 \text { de } 2009 \text { e } n^{0} 2.143 \text { de } 2013 \text {. }\end{array}$ \\
\hline Monte Mor & Lei 1.431 & 2009 & Lei 1.431 & 2009 & NÃO TEM & & $\begin{array}{l}\text { A informação sobre a inexistência do } \\
\text { PLHIS foi obtida por meio de telefonema } \\
\text { em 02/2016. }\end{array}$ & $\begin{array}{l}\text { Em 02/2016, por meio de contato com o } \\
\text { secretário de Obras do município, obteve-se a } \\
\text { informação de que as leis de conselho e fundo } \\
\text { estão em vigor, entretanto eles estão } \\
\text { desativados e estão sendo utilizados o conselho } \\
\text { e fundo municipais de Assistência Social. }\end{array}$ \\
\hline Morungaba & Lei 1.225 & 2008 & Lei 1.225 & 2008 & NÃO TEM & & $\begin{array}{l}\text { A informação sobre a inexistência do } \\
\text { PLHIS foi obtida da secretaria de Obras } \\
\text { em 01/2016, depois de protocolo nº } \\
548 / 03 / 15 \text {, aberto em março de } 2015 \text {. }\end{array}$ & \\
\hline
\end{tabular}




\begin{tabular}{|c|c|c|c|c|c|c|c|c|}
\hline \multirow[t]{2}{*}{ Municípios } & \multicolumn{2}{|c|}{$\begin{array}{l}\text { FUNDO DE } \\
\text { HABITAÇÃOO }\end{array}$} & \multicolumn{2}{|c|}{$\begin{array}{l}\text { CONSELHO DE } \\
\text { HABITAÇÃOO }\end{array}$} & \multicolumn{3}{|c|}{ PLANO LOCAL DE HABITAÇÃO | PLHIS } & \multirow{2}{*}{$\begin{array}{l}\text { Alterações nas legislações / leis } \\
\text { complementares ou outras observações }\end{array}$} \\
\hline & Lei $\left(n^{0}\right)$ & Data & Lei $\left(n^{0}\right)$ & Data & Existência & Data & Observações & \\
\hline $\begin{array}{l}\text { Nova } \\
\text { Odessa }\end{array}$ & Lei 2.258 & 2007 & Lei 2.258 & 2007 & Tem PLHIS & 2010 & & $\begin{array}{l}\text { A Lei } 2.491 / 2011 \text { altera a Lei municipal } \\
2.258 / 2007 \text { de Nova Odessa, que cria o } \\
\text { Conselho e Fundo Municipais de Habitação. }\end{array}$ \\
\hline Paulínia & Lei 3.012 & 2009 & Lei 3.012 & 2009 & NÃO TEM & & $\begin{array}{l}\text { Obteve-se a informação sobre a } \\
\text { inexistência de PLHIS em entrevista com } \\
\text { técnico municipal da secretaria de } \\
\text { planejamento em } 28 / 05 / 2015 \text {. }\end{array}$ & $\begin{array}{l}\text { As Leis } n^{0} 3.155 / 2010 \text { e } n^{0} 3.048 / 2009 \text { alteram } \\
\text { a Lei 3012/2009. }\end{array}$ \\
\hline Pedreira & Lei 2.708 & 2007 & Lei 2.708 & 2007 & Tem PLHIS & 2012 & $\begin{array}{l}\text { O PLHIS começou a ser elaborado em } \\
\text { 2008, mas foi finalizado e aprovado em } \\
2012 \text {. }\end{array}$ & $\begin{array}{l}\text { A Lei } 2.708 / 2007 \text { cria o fundo municipal de } \\
\text { habitação e institui seu conselho gestor. A } \\
\text { Portaria municipal } 295 / 2009 \text { altera a } \\
\text { composição do conselho e a Lei } 300 / 2009 \\
\text { nomeia os representantes do fundo municipal. }\end{array}$ \\
\hline $\begin{array}{l}\text { Santa } \\
\text { Bárbara } \\
\text { d'Oeste }\end{array}$ & Lei 3.297 & 2011 & Lei 3.297 & 2011 & Tem PLHIS & 2011 & $\begin{array}{l}\text { O PLHIS é aprovado como anexo da Lei } \\
3.297 / 11 \text {. }\end{array}$ & $\begin{array}{l}\text { A Lei Municipal de Santa Bárbara no } 3.046 / 2008 \\
\text { criou, anteriormente, o Fundo Municipal de } \\
\text { Habitação, sendo revogada pela Lei 3.297/2011. }\end{array}$ \\
\hline \begin{tabular}{|l|} 
Santo \\
Antônio de \\
Posse \\
\end{tabular} & Lei 2.731 & 2012 & $\begin{array}{l}\text { Lei } \\
2.731 / 12\end{array}$ & 2012 & Possui & $\begin{array}{l}2011 \\
\text { (Nov) }\end{array}$ & & \\
\hline Sumaré & Lei 4.545 & 2007 & Lei 4.545 & 2007 & Tem PLHIS & $\begin{array}{l}2011 \\
(\operatorname{Jan})\end{array}$ & & $\begin{array}{l}\text { A Lei 4.545/2007, que regulamenta sobre o } \\
\text { Fundo, o Conselho Municipal de Habitação, a } \\
\text { política municipal de habitação e institui a } \\
\text { Conferência Municipal de habitação, é alterada } \\
\text { pela Lei no } 5.172 / 2011 \text {. }\end{array}$ \\
\hline Valinhos & Lei 4.375 & 2008 & Lei 4.375 & 2008 & Tem PLHIS & 2009 & & \\
\hline Vinhedo & Lei 3.075 & 2007 & Lei 3.075 & 2007 & Tem PLHIS & 2007 & & \\
\hline
\end{tabular}

Fonte: sistematização realizada pela autora a partir da leitura das leis de fundo, conselho e plano local de habitação de interesse social dos municípios da Região Metropolitana de Campinas. 
A seguir, um mapa síntese, apresentando quais municípios possuem os três itens fundo, conselho e PLHIS (Plano Local de Habitação de Interesse Social), quais possuem os dois primeiros itens e qual município não apresenta nenhum dos itens.

\section{Mapa 5 - Municípios que possuem Fundo Municipal de Habitação, Conselho e PLHIS}

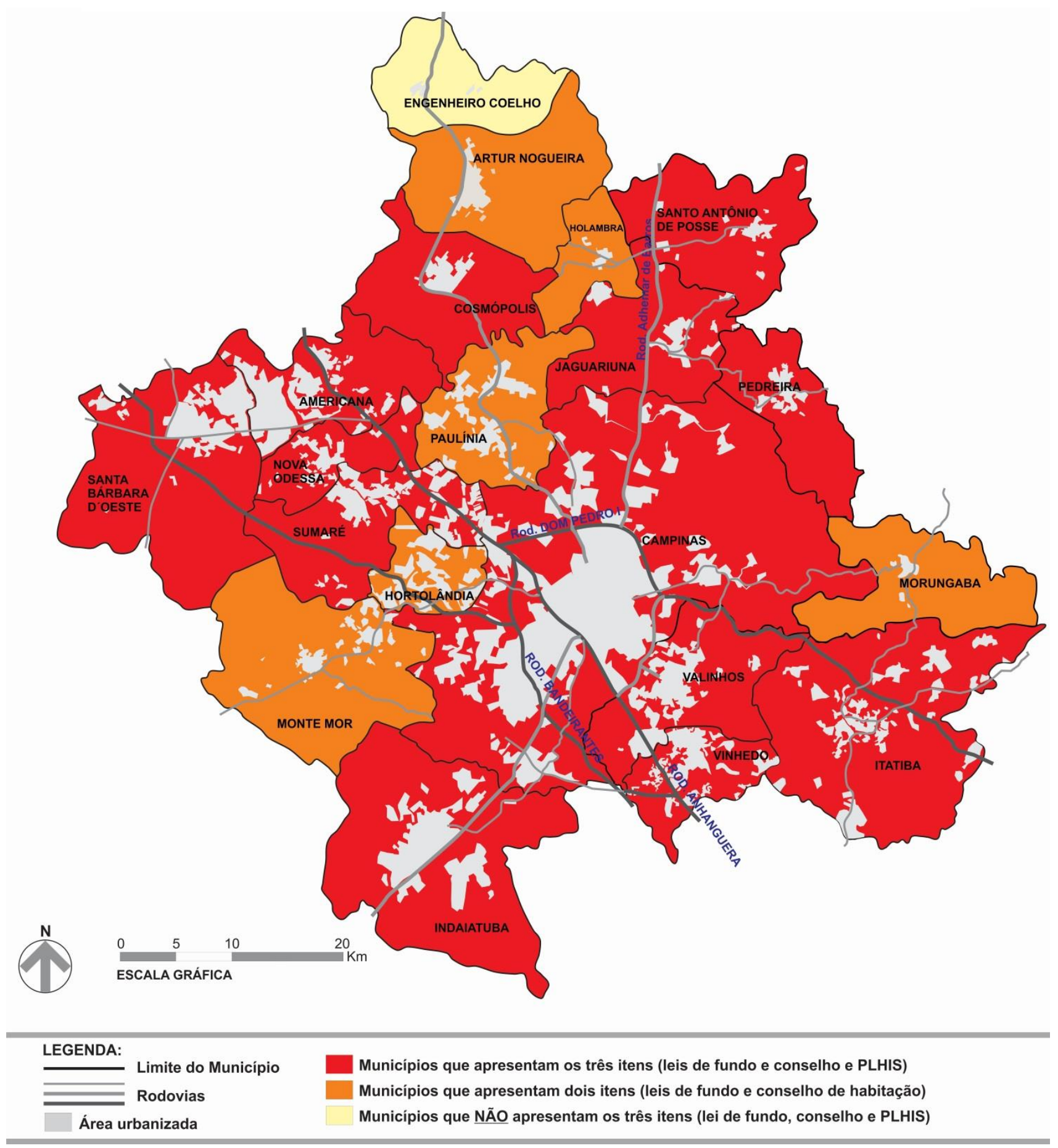

Fonte do mapa: identificação dos municípios realizada pela autora, a partir da leitura das leis e planos vigentes em 2014. 


\subsection{Considerações sobre as Regulamentações Municipais para Habitação de Interesse Social na RMC}

A partir das análises das regulamentações municipais na Região Metropolitana de Campinas, pode-se perceber que existem grupos de municípios conforme as "ferramentas urbanísticas" para a produção de Habitação de Interesse Social. Foi possível notar que o grupo de municípios com poucos instrumentos nos planos diretores, denominado grupo $\mathrm{C}$ (ver Mapa 4, p. 64), coincide em sua maioria com o grupo de municípios que não dispõem dos três itens para obtenção de recursos do governo federal (ver Mapa 5, p. 71). Ou seja, aqueles municípios que possuem uma estrutura técnico-administrativa reduzida ${ }^{65}$ não conseguem se utilizar da diversidade de instrumentos urbanísticos em seus planos diretores e, da mesma forma, não conseguem obter os itens necessários para obtenção de recursos do governo federal para habitação: lei de fundo e conselho de habitação e PLHIS (Plano Local de Habitação de Interesse Social).

Percebe-se, portanto, que quando são colocados parâmetros iguais para obtenção de um de determinado recurso do governo federal ou mesmo a disponibilização dos mesmos instrumentos urbanísticos para os planos diretores (a partir do Estatuto da Cidade), independentemente das escalas e peculiaridades municipais, tem-se, ao invés de uma maior isonomia, a exacerbação da diferença entre eles, visto que para alguns é fácil utilizar os instrumentos urbanísticos propostos, assim como a elaboração de planos locais, enquanto para outros, devido à estrutura técnico-administrativa disponível, é mais difícil. Cabe ressaltar, ainda, as questões políticas e alianças entre governos que privilegiam alguns municípios.

No entanto, a discussão sobre a elaboração dos planos e as questões políticas que permeiam todas as regulamentações constituiria outro trabalho. O enfoque deste capítulo é um panorama da instrumentalização dos municípios perante a problemática habitacional e a percepção dos grupos de municípios que dispõem de mais "ferramentas" para a produção de Habitação de Interesse Social, de modo que se possa perceber como isso reflete na produção das HIS dos municípios da RMC, produção que será apresentada no próximo capítulo.

\footnotetext{
${ }^{65}$ A partir da visita para o levantamento de dados, percebeu-se que os menores municípios apresentam um número pequeno de funcionários, os quais desempenham diversas funções e, em alguns casos, eles demonstram um desconhecimento da legislação e dos instrumentos urbanísticos voltados à Habitação de Interesse Social. Para agravar, a estrutura física, como mesas, computadores e a disponibilização de softwares, é insuficiente.
} 


\section{Capítulo III - A produção de Habitação de Interesse Social na Região Metropolitana de Campinas}

Neste capítulo, são apresentados todos os conjuntos de Habitações de Interesse Social (HIS) realizados nos municípios da Região Metropolitana de Campinas (RMC), de 1964 até 2014. Na sequência, são apresentados alguns casos "especiais" de produção de Habitação de Interesse Social, em que os municípios adotaram soluções não recorrentes para lidar com o problema da carência de HIS.

Trata-se, assim, de circunscrever o conjunto de iniciativas que configuram a produção de Habitação de Interesse Social, entendida como uma realização promovida pelo estado, com aporte direto, subsídio, apoio ou financiamento facilitado, oferecendo um produto que escapa em alguma medida às regras puramente concorrenciais do mercado. São casos em que a demanda deve qualificar-se com relação a uma faixa de renda considerada baixa, tendo variado, ao longo do tempo, tanto os critérios quanto os programas que respondiam a tal demanda, mas, em sua maioria, relacionando-se a faixas de renda definidas em termos de salário mínimo. No início do $\mathrm{BNH}$, eram incluídos nos programas públicos - basicamente promovidos pelas COHABs - a faixa de 0 a 6 salários mínimos. Por ocasião do lançamento do Minha Casa Minha Vida, em 2009, após quase uma década de aumentos reais do salário mínimo, definiram-se algumas faixas, em que aquela mais expressiva enquanto Habitação de Interesse Social, beneficiária de subsídios diretos, não reembolsáveis, provenientes do Orçamento Geral da União, é a de 0 a 3 salários mínimos.

O termo Habitação de Interesse Social, presente desde a criação do BNH, voltou a ser qualificado a partir do projeto de lei de iniciativa popular, de 1991, que propunha a criação do Fundo Nacional de Habitação de Interesse Social. O projeto foi apreciado pelo Congresso apenas em 2004, dando origem à Lei no 11.124 de 2005, que dispõe sobre o Sistema Nacional de Habitação de Interesse Social - SNHIS, cria o Fundo Nacional de Habitação de Interesse Social - FNHIS e institui o Conselho Gestor do FNHIS. O SNHIS tem o objetivo de "viabilizar para a população de menor renda o acesso à terra urbanizada e à habitação digna e sustentável" (Art. 20, inciso I).

O presente capítulo apresenta análises por décadas, comparando as quantidades de unidades de Habitação de Interesse Social com o total de domicílios em cada município, de modo que seja possível perceber os municípios que apresentam maior percentual de HIS em cada período. São evidenciadas as relações dessas produções com a instituição de instrumentos urbanísticos nos planos diretores, e discutem-se algumas causas relativas à produção de Habitação de Interesse Social. 


\subsection{Conjuntos habitacionais produzidos na RMC de 1964 a 2014}

Apresentam-se, neste ponto, as produções de Habitações de Interesse Social dos vinte municípios da Região Metropolitana de Campinas em tabelas, nas quais os conjuntos foram organizados por ordem cronológica de implantação. Os seguintes dados das HIS são tratados: a data de entrega, o nome, o agente financeiro ou parcerias (pois muitas vezes a COHAB ou cooperativas não contribuíram no aporte financeiro, mas foram fundamentais para o desenvolvimento dos conjuntos) e, por último, a coluna com as observações em que foram colocadas informações sobre tamanho das unidades habitacionais, especificações sobre como foi realizado o empreendimento, a participação dos agentes financeiros ou outras informações adicionais fornecidas pelos técnicos municipais. Os dados foram pesquisados entre janeiro de 2014 e dezembro de $2015^{66}$.

Nas últimas linhas de cada tabela, apresenta-se o total geral de unidades habitacionais e conforme as tipologias: total de casas, lotes urbanizados e apartamentos. Os conjuntos que não foram mapeados estão destacados na cor azul escuro, além de estar anotada a ausência do mapeamento na coluna "observações".

Ressalta-se que esse extenso levantamento foi realizado a partir de visitas às vinte prefeituras municipais, além de considerar as informações dos planos municipais de habitação, quando existiam, e consultas à CDHU, à COHAB Campinas, à Caixa Econômica Federal (para os projetos Minha Casa Minha Vida - faixas 2 e 3) e à pesquisa da Rede Cidade e Moradia (FERRAMENTAS [...], 2014). Portanto, esses dados de fonte primária, fundamentais para o desenvolvimento da pesquisa, são fruto de diversas visitas e entrevistas. Para os municípios de Campinas, Cosmópolis, Hortolândia, Itatiba, Monte Mor, Morungaba, Paulínia e Santa Bárbara d'Oeste, mesmo após contato com a secretaria responsável pela questão de habitação e/ou planejamento urbano, foi necessária a abertura de protocolo na prefeitura, solicitando oficialmente as informações, sendo que, para alguns desses casos, foi necessário o pagamento de uma taxa. Além disso, diversos municípios demandaram mais de uma visita, visto que os dados eram fornecidos apenas em etapas.

As informações sobre os conjuntos habitacionais de interesse social, a princípio públicas, foram, na maioria dos casos, de difícil acesso e absorveram um grande tempo neste trabalho. A dificuldade ocorreu em função da diversidade de escala dos municípios, o que refletiu em estruturas municipais e condições técnicas bastante díspares, da variedade de formas como as informações foram obtidas e na ausência de arquivos municipais. Em

\footnotetext{
${ }^{66}$ As informações obtidas antes do final de 2014 foram, em 2015, confirmadas via e-mail ou por telefonema à secretaria correspondente, visto que o recorte temporal da pesquisa se estende até o fim de 2014.
} 
alguns casos, os dados foram obtidos a partir de entrevistas com técnicos mais antigos das instituições. Cabe lembrar que isso não ocorreu apenas nos pequenos municípios, embora neles tenha sido mais recorrente. No caso de Campinas, por exemplo, para os dados de alguns conjuntos, como no Vila Esperança e no Padre Anchieta, na ausência de arquivos, foi utilizada como fonte a narrativa dos técnicos municipais mais antigos.

É importante observar que em dois municípios, Valinhos e Jaguariúna, quando foram solicitados os dados sobre as Habitações de Interesse Social, os técnicos informaram que não existiam de forma sistematizada e, apenas após certo tempo, eles foram fornecidos. Em janeiro de 2016, observou-se que parte das informações solicitadas estava disponível nos sites das prefeituras. Acredita-se que essa disponibilização dos dados seja em parte devido à solicitação realizada para o desenvolvimento da pesquisa.

A despeito das dificuldades relativas ao levantamento de dados, houve um esforço de se obter as informações de todos os conjuntos realizados desde 1964 até 2014 nos vinte municípios da Região Metropolitana de Campinas. Além disso, houve o cruzamento de informações de diferentes instituições e fontes, conforme acima mencionado. Mas é claro que, considerando a dimensão do levantamento, pode haver omissões. Feitas essas observações, ressalta-se que foram levantados 504 casos, entre conjuntos habitacionais e formas equivalentes, que correspondem a 149.701 unidades habitacionais em toda a Região Metropolitana de Campinas (ver Tabela 29, p. 136). 
Tabela 6 - Dados das Habitações de Interesse Social produzidas em Americana (1964-2014)

\begin{tabular}{|c|c|c|c|c|c|}
\hline \multicolumn{6}{|c|}{ Produção Habitacional de Americana } \\
\hline & $\begin{array}{l}\text { Ano de } \\
\text { entrega }\end{array}$ & $\begin{array}{l}\text { Nome do } \\
\text { Conjunto }\end{array}$ & \begin{tabular}{|c|} 
Agente \\
financeiro \\
/ Parcerias \\
\end{tabular} & \begin{tabular}{|c|}
$N^{\circ}$ de \\
Unidades \\
Habitacionais \\
\end{tabular} & Observações \\
\hline 01 & 1978 & \begin{tabular}{|l|} 
Conj. Hab. \\
Antônio Zanaga I
\end{tabular} & $\begin{array}{l}\text { COHAB-Campinas } \\
\text { e BNH }\end{array}$ & 709 casas & \multirow{2}{*}{$\begin{array}{l}\text { Houve recursos do BNH (Banco } \\
\text { Nacional de Habitação). }\end{array}$} \\
\hline 02 & 1980 & $\begin{array}{l}\text { Conj. Hab. } \\
\text { Antônio Zanaga II }\end{array}$ & $\begin{array}{l}\text { COHAB-Campinas } \\
\text { e BNH }\end{array}$ & 1806 casas & \\
\hline 03 & $12 / 1982$ & $\begin{array}{l}\text { Jd. Nossa Sra } \\
\text { Aparecida - Lotes } \\
\text { Urb. Profilurb }\end{array}$ & $\begin{array}{l}\text { CDHU e Prefeitura } \\
\text { de Americana }\end{array}$ & 683 lotes & $\begin{array}{l}\text { Foram entregues o lote e uma } \\
\text { unidade sanitária. } \\
\text { Houve financiamento dos lotes para } \\
\text { os munícipes. }\end{array}$ \\
\hline 04 & 1990 & $\begin{array}{l}\text { Cidade Jardim/ } \\
\text { Gerânios }\end{array}$ & $\begin{array}{l}\text { Prefeitura de } \\
\text { Americana }\end{array}$ & $\begin{array}{l}38 \text { lotes } \\
\text { urbanizados }\end{array}$ & \multirow{8}{*}{$\begin{array}{l}\text { Foram realizados loteamentos em } \\
\text { áreas públicas e financiamento para } \\
\text { os munícipes. Em alguns casos, } \\
\text { houve programa de mutirão. }\end{array}$} \\
\hline 05 & 1990 & Vila Mathiensen & \begin{tabular}{|l|} 
Prefeitura de \\
Americana \\
\end{tabular} & $\begin{array}{l}22 \text { lotes } \\
\text { urbanizados }\end{array}$ & \\
\hline 06 & 1990 & Jd. Guanabara & \begin{tabular}{|l} 
Prefeitura de \\
Americana
\end{tabular} & $\begin{array}{l}60 \text { lotes } \\
\text { urbanizados }\end{array}$ & \\
\hline 07 & 1990 & Balneário Riviera & $\begin{array}{l}\text { Prefeitura de } \\
\text { Americana }\end{array}$ & $\begin{array}{l}16 \text { lotes } \\
\text { urbanizados }\end{array}$ & \\
\hline 08 & 1990 & São Jerônimo & \begin{tabular}{|l|} 
Prefeitura de \\
Americana \\
\end{tabular} & $\begin{array}{l}103 \text { lotes } \\
\text { urbanizados }\end{array}$ & \\
\hline 09 & 1990 & $\begin{array}{l}\text { São Jerônimo - } \\
\text { Lotes Urb. }\end{array}$ & \begin{tabular}{|l} 
Prefeitura de \\
Americana
\end{tabular} & $\begin{array}{l}64 \text { lotes } \\
\text { urbanizados }\end{array}$ & \\
\hline 10 & 1990 & $\begin{array}{l}\text { Jd Brasil -Lotes } \\
\text { Urbanizados }\end{array}$ & $\begin{array}{l}\text { Prefeitura de } \\
\text { Americana }\end{array}$ & $\begin{array}{l}142 \text { lotes } \\
\text { urbanizados }\end{array}$ & \\
\hline 11 & 1990 & $\begin{array}{l}\text { Vila Bela Lotes } \\
\text { Urbanizados }\end{array}$ & $\begin{array}{l}\text { Prefeitura de } \\
\text { Americana }\end{array}$ & $\begin{array}{l}254 \text { lotes } \\
\text { urbanizados }\end{array}$ & \\
\hline 12 & 1990 & Lilazes Mutirão & $\begin{array}{l}\text { Prefeitura de } \\
\text { Americana }\end{array}$ & 110 casas & $\begin{array}{l}\text { A prefeitura fez o projeto e abriu o } \\
\text { loteamento. Além disso, realizou, } \\
\text { com os inscritos pela Secretaria de } \\
\text { Habitação, o projeto de mutirão, } \\
\text { tudo por meio de recursos da } \\
\text { prefeitura. }\end{array}$ \\
\hline 13 & 1991 & $\begin{array}{l}\text { Jardim Brasil } \\
\text { Mutirão }\end{array}$ & $\begin{array}{l}\text { Prefeitura de } \\
\text { Americana }\end{array}$ & 52 casas & $\begin{array}{l}\text { A prefeitura, com recursos próprios, } \\
\text { fez o projeto, executou o } \\
\text { loteamento, financiou os lotes para } \\
\text { os munícipes e realizou o mutirão. }\end{array}$ \\
\hline 14 & 1991 & $\begin{array}{l}\text { Jardim da Paz } \\
\text { Lotes Urbanizados }\end{array}$ & $\begin{array}{l}\text { Prefeitura de } \\
\text { Americana }\end{array}$ & $\begin{array}{l}103 \text { lotes } \\
\text { urbanizados }\end{array}$ & $\begin{array}{l}\text { A prefeitura, com recursos próprios, } \\
\text { realizou o loteamento e fez o } \\
\text { financiamento para os munícipes. }\end{array}$ \\
\hline 15 & 1992 & $\begin{array}{l}\text { Pq. Residencial } \\
\text { Guaicurus }\end{array}$ & $\begin{array}{l}\text { INOCOOP } \\
\text { Bandeirantes }\end{array}$ & $\begin{array}{l}450 \\
\text { apartamentos }\end{array}$ & \\
\hline 16 & 1992 & $\begin{array}{l}\text { Jardim da Paz } \\
\text { Mutirão }\end{array}$ & $\begin{array}{l}\text { Prefeitura de } \\
\text { Americana }\end{array}$ & 234 casas & \\
\hline
\end{tabular}

${ }^{67}$ A informação sobre a data de entrega dos conjuntos Parque Arkansas (2014) e Parque Asteca (2013) foi obtida por meio de entrevista (realizada em 16/01/2016) com moradores que ocupam o empreendimento desde o início, visto que não foi possível obter essa informação diretamente no agente financeiro ou na prefeitura municipal, como ocorreu em todos os outros casos. 


\begin{tabular}{|c|c|c|c|c|c|}
\hline \multicolumn{6}{|c|}{ Produção Habitacional de Americana } \\
\hline & $\begin{array}{l}\text { Ano de } \\
\text { entrega }\end{array}$ & $\begin{array}{l}\text { Nome do } \\
\text { Conjunto }\end{array}$ & \begin{tabular}{|c|} 
Agente \\
financeiro \\
/Parcerias
\end{tabular} & $\begin{array}{c}N^{0} \text { de } \\
\text { Unidades } \\
\text { Habitacionais }\end{array}$ & Observações \\
\hline 17 & $1992 / 93$ & $\begin{array}{l}\text { Lotes Particulares } \\
\text { Jd. Da Paz }\end{array}$ & $\begin{array}{l}\text { Prefeitura de } \\
\text { Americana e } \\
\text { COHAB Ribeirão } \\
\text { Preto }\end{array}$ & 637 lotes & $\begin{array}{l}\text { A prefeitura fez a desapropriação } \\
\text { da do Jd. da Paz, e como } \\
\text { pagamento pela desapropriação, os } \\
\text { proprietários receberam uma área } \\
\text { parcelada, que foi vendida como } \\
\text { HIS }^{68} \text {. }\end{array}$ \\
\hline 18 & $1992 / 93$ & $\begin{array}{l}\text { Pq. da Liberdade - } \\
\text { lotes particulares }\end{array}$ & $\begin{array}{l}\text { Prefeitura de } \\
\text { Americana e } \\
\text { iniciativa privada }\end{array}$ & 731 lotes & $\begin{array}{l}\text { No Parque da Liberdade, o } \\
\text { processo de parcelamento ocorreu } \\
\text { de forma semelhante ao Jd. da Paz } \\
\text { - os lotes particulares foram } \\
\text { pagamento por desapropriação da } \\
\text { área. }^{69}\end{array}$ \\
\hline 19 & $1992 / 93$ & $\begin{array}{l}\text { Jardim das Flores } \\
\text { - Lotes } \\
\text { Urbanizados }\end{array}$ & $\begin{array}{l}\text { Prefeitura de } \\
\text { Americana }\end{array}$ & 168 lotes & $\begin{array}{l}\text { A área era da prefeitura, que } \\
\text { realizou o loteamento e fez } \\
\text { financiamento para os munícipes. }\end{array}$ \\
\hline 20 & 1993 & Vila Bela Mutirão & \begin{tabular}{|l} 
Prefeitura de \\
Americana
\end{tabular} & 128 casas & $\begin{array}{l}\text { A prefeitura, com recursos próprios, } \\
\text { realizou o loteamento com mutirão } \\
\text { e financiamento de material e do } \\
\text { lote. }\end{array}$ \\
\hline 21 & 1993 & $\begin{array}{l}\text { Conj. Hab. Jardim } \\
\text { do Lago }\end{array}$ & \begin{tabular}{|l} 
Caixa Econômica \\
Federal e \\
Prefeitura de \\
Americana \\
\end{tabular} & 234 casas & $\begin{array}{l}\text { O Conjunto foi construído por } \\
\text { construtora, e a população atendida } \\
\text { foi a inscrita pela Secretaria de } \\
\text { Habitação do município. }\end{array}$ \\
\hline 22 & 02/1994 & $\begin{array}{l}\text { Conj. Hab. Parque } \\
\text { da Liberdade }\end{array}$ & $\begin{array}{l}\text { CDHU - São } \\
\text { Paulo }\end{array}$ & 700 casas & \\
\hline 23 & 02/1994 & $\begin{array}{l}\text { Conj. Hab. Jardim } \\
\text { da Paz }\end{array}$ & $\begin{array}{l}\text { COHAB-Ribeirão } \\
\text { Preto }\end{array}$ & 401 casas & \\
\hline 24. & 1995 & $\begin{array}{l}\text { Conj. Hab. São } \\
\text { Jerônimo II }\end{array}$ & $\begin{array}{l}\text { COHAB-Ribeirão } \\
\text { Preto }\end{array}$ & 543 casas & \\
\hline 25 & 1996 & $\begin{array}{l}\text { Pq. da Liberdade } \\
\text { Lotes Urb. }\end{array}$ & \begin{tabular}{|l} 
Prefeitura de \\
Americana
\end{tabular} & $\begin{array}{l}14 \text { lotes } \\
\text { urbanizados }\end{array}$ & $\begin{array}{l}\text { A prefeitura realizou o loteamento e } \\
\text { o financiamento para os munícipes. }\end{array}$ \\
\hline 26 & 1996 & $\begin{array}{l}\text { Jardim dos Lírios - } \\
\text { Módulos }\end{array}$ & $\begin{array}{l}\text { Prefeitura de } \\
\text { Americana }\end{array}$ & $\begin{array}{l}132 \text { casas } \\
\text { (módulos) }\end{array}$ & $\begin{array}{l}\text { Na maior parte do loteamento, os } \\
\text { proprietários dos módulos } \\
\text { realizaram ampliações e } 16 \\
\text { unidades foram ampliadas por meio } \\
\text { de recursos do Fundo Nacional de } \\
\text { Habitação de Interesse Social } \\
\text { (FNHIS). }\end{array}$ \\
\hline 27 & 1997 & $\begin{array}{l}\text { Jd. dos Lírios - } \\
\text { Lotes particulares }\end{array}$ & \begin{tabular}{|l|} 
Prefeitura de \\
Americana, \\
iniciativa privada \\
e COOPERTETO \\
(Cooperativa \\
Nacional de \\
Habitação e \\
Construção)
\end{tabular} & 455 lotes & $\begin{array}{l}\text { Essa área particular foi parcelada } \\
\text { pela prefeitura, pois havia nela uma } \\
\text { favela, e foi realizada uma } \\
\text { negociação entre poder público e } \\
\text { iniciativa privada. } 70\end{array}$ \\
\hline
\end{tabular}

\footnotetext{
${ }^{68}$ Mais informações em "Limites tênues entre poder público e iniciativa privada | município de Americana" (p. 115).

${ }^{69}$ Ver mais informações na página 116.

${ }^{70}$ Ver mais informações sobre o processo de parcelamento na página 116.
} 


\begin{tabular}{|c|c|c|c|c|c|}
\hline \multicolumn{6}{|c|}{ Produção Habitacional de Americana } \\
\hline & $\begin{array}{l}\text { Ano de } \\
\text { entrega }\end{array}$ & $\begin{array}{l}\text { Nome do } \\
\text { Conjunto }\end{array}$ & \begin{tabular}{|c|} 
Agente \\
financeiro \\
/Parcerias \\
\end{tabular} & $\begin{array}{c}N^{0} \text { de } \\
\text { Unidades } \\
\text { Habitacionais }\end{array}$ & Observações \\
\hline 28. & 1997-98 & $\begin{array}{l}\text { Jardim dos Lírios - } \\
\text { Mutirão }\end{array}$ & $\begin{array}{l}\text { Prefeitura de } \\
\text { Americana }\end{array}$ & 108 casas & \\
\hline 29 & 1999 & $\begin{array}{l}\text { Jardim dos Lírios- } \\
\text { Mutirão }\end{array}$ & $\begin{array}{l}\text { Prefeitura de } \\
\text { Americana e CEF }\end{array}$ & 136 casas & \\
\hline 30 & 1999 & $\begin{array}{l}\text { Pq. da Liberdade } \\
\text { - Mutirão }\end{array}$ & $\begin{array}{l}\text { Prefeitura de } \\
\text { Americana e CEF }\end{array}$ & 156 casas & \\
\hline 31 & $2000-02$ & $\begin{array}{l}\text { Jardim dos Lírios - } \\
\text { Mutirão }\end{array}$ & \begin{tabular}{|l|} 
Prefeitura de \\
Americana / CEF / \\
COOPERTETO \\
\end{tabular} & $\begin{array}{l}184 \text { casas } \\
\text { (sobrados e } \\
\text { térreas) }\end{array}$ & $\begin{array}{l}\text { Foram } 143 \text { sobrados realizados em } \\
2000 \text { e } 41 \text { casas térreas em } 2002 .\end{array}$ \\
\hline 32 & $2000-03$ & Vila Bela Mutirão & \begin{tabular}{|l|} 
Prefeitura de \\
Americana / CEF \\
e COOPERTETO \\
\end{tabular} & $\begin{array}{l}48 \text { casas } \\
\text { (sobrados) }\end{array}$ & \\
\hline 33 & $2000-02$ & $\begin{array}{l}\text { Conj. Vitória I - } \\
\text { Mathiensen }\end{array}$ & \begin{tabular}{|l|} 
ASTA (Associação \\
dos Sem Teto de \\
Americana) e \\
Prefeitura de \\
Americana
\end{tabular} & 66 lotes & \multirow{4}{*}{$\begin{array}{l}\text { A prefeitura fez o projeto do } \\
\text { loteamento, a aprovação e deu } \\
\text { assistência técnica em alguns } \\
\text { projetos de mutirão (recurso } \\
\text { federal). As áreas eram de } \\
\text { propriedade da ASTA (Associação } \\
\text { dos Sem Teto de Americana) ou da } \\
\text { COOPERTETO. }\end{array}$} \\
\hline 34 & $2000-04$ & $\begin{array}{l}\text { Jardim da Mata - } \\
\text { Lotes Urb. - Praia } \\
\text { Azul }\end{array}$ & \begin{tabular}{|l|} 
COOPERTETO e \\
Prefeitura de \\
Americana \\
\end{tabular} & 416 lotes & \\
\hline 35 & $2002-03$ & $\begin{array}{l}\text { Conj. Novo } \\
\text { Paraíso III - Praia } \\
\text { Namorados } \\
\end{array}$ & $\begin{array}{l}\text { ASTA e Prefeitura } \\
\text { de Americana }\end{array}$ & 350 lotes & \\
\hline 36 & 2003-04 & $\begin{array}{l}\text { Conj. Nova } \\
\text { Esperança IV / } \\
\text { Asta IV } \\
\end{array}$ & $\begin{array}{l}\text { ASTA e Prefeitura } \\
\text { de Americana }\end{array}$ & 100 lotes & \\
\hline 37 & $03 / 2004$ & $\begin{array}{l}\text { Conj. Hab. Mário } \\
\text { Covas }(D, E, F)\end{array}$ & $\begin{array}{l}\text { CDHU e Prefeitura } \\
\text { de Americana }\end{array}$ & $\begin{array}{l}287 \text { casas e } 160 \\
\text { apartamentos }\end{array}$ & \\
\hline 38 & 2004 & $\begin{array}{l}\text { Jd. Novo } \\
\text { Horizonte - Lotes } \\
\text { Urbanizados }\end{array}$ & $\begin{array}{l}\text { COOPERTETO e } \\
\text { Prefeitura de } \\
\text { Americana }\end{array}$ & 197 lotes & $\begin{array}{l}\text { A prefeitura fez o projeto do } \\
\text { loteamento, a aprovação e deu } \\
\text { assistência técnica. As áreas eram } \\
\text { de propriedade da COOPERTETO. }\end{array}$ \\
\hline 39 & 2006 & $\begin{array}{l}\text { Pq. da Liberdade - } \\
\text { Lotes Urbanizados }\end{array}$ & $\begin{array}{l}\text { COOPERTETO e } \\
\text { Prefeitura de } \\
\text { Americana }\end{array}$ & 47 lotes & $\begin{array}{l}\text { A prefeitura fez o projeto do } \\
\text { loteamento, a aprovação e } \\
\text { executou. }\end{array}$ \\
\hline 40 & $\begin{array}{l}2006- \\
2007\end{array}$ & $\begin{array}{l}\text { Pq. da Liberdade - } \\
\text { Mutirão }\end{array}$ & $\begin{array}{l}\text { Prefeitura de } \\
\text { Americana /PSH } \\
\text { (CEF) }\end{array}$ & 50 casas & $\begin{array}{l}\text { PSH (Programa de Subsídio } \\
\text { Habitacional do governo federal) }\end{array}$ \\
\hline 41 & 2007 & $\begin{array}{l}\text { Jd. dos Lírios - } \\
\text { Mutirão Casa e } \\
\text { Muro de Arrimo }\end{array}$ & $\begin{array}{l}\text { Prefeitura de } \\
\text { Americana e CEF }\end{array}$ & 104 casas & \\
\hline 42 & 2007 & $\begin{array}{l}\text { Jd. da Mata - } \\
\text { Mutirão OGU }\end{array}$ & $\begin{array}{l}\text { Prefeitura de } \\
\text { Americana/ OGU } \\
\text { /CEF e } \\
\text { COOPERTETO } \\
\end{array}$ & $\begin{array}{l}38 \text { sobrados e } \\
13 \text { casas }\end{array}$ & $\begin{array}{l}\text { Tipo casa embrião. } \\
\text { Fonte de recurso: OGU (Orçamento } \\
\text { Geral da União). }\end{array}$ \\
\hline 43 & 2008 & $\begin{array}{l}\text { Vila Dainese } \\
\text { /Residencial } \\
\text { Nogueira Martins }\end{array}$ & PAR e CEF & $\begin{array}{l}176 \\
\text { apartamentos }\end{array}$ & $\begin{array}{l}\text { PAR: Programa de Arrendamento } \\
\text { Residencial. }\end{array}$ \\
\hline 44 & 2009 & $\begin{array}{l}\text { Jd. da Mata } \\
\text { Mutirão PSH }\end{array}$ & $\begin{array}{l}\text { COOPERTETO, } \\
\text { PSH, Prefeitura de } \\
\text { Americana e } \\
\text { COHAB }\end{array}$ & $\begin{array}{l}52 \text { casas } \\
\text { (sobrados) }\end{array}$ & $\begin{array}{l}\text { COOPERTETO (Cooperativa } \\
\text { Nacional de Habitação e } \\
\text { Construção) e PSH (Programa de } \\
\text { Subsídio Habitacional do governo } \\
\text { federal) }\end{array}$ \\
\hline
\end{tabular}




\begin{tabular}{|c|c|c|c|c|c|}
\hline \multicolumn{6}{|c|}{ Produção Habitacional de Americana } \\
\hline & $\begin{array}{l}\text { Ano de } \\
\text { entrega }\end{array}$ & $\begin{array}{l}\text { Nome do } \\
\text { Conjunto }\end{array}$ & $\begin{array}{c}\text { Agente } \\
\text { financeiro } \\
\text { / Parcerias }\end{array}$ & $\begin{array}{c}N^{0} \text { de } \\
\text { Unidades } \\
\text { Habitacionais }\end{array}$ & Observações \\
\hline 45 & 2009 & $\begin{array}{l}\text { Jd Novo Horizonte } \\
\text {-Mutirão Crédito } \\
\text { Solidário }\end{array}$ & $\begin{array}{l}\text { Prefeitura de } \\
\text { Americana / CEF } \\
\text { e COOPERTETO }\end{array}$ & $\begin{array}{l}25 \text { casas } \\
\text { (sobrados) }\end{array}$ & \\
\hline 46 & $02 / 2010$ & Cond. Res. Safira & $\begin{array}{l}\text { Minha Casa Minha } \\
\text { Vida II / III (CEF) }\end{array}$ & $\begin{array}{l}12 \\
\text { apartamentos }\end{array}$ & $\begin{array}{l}\text { Faixa 2/ } 3 \text { do MCMV. } \\
\text { Empreendedora de Imóveis } \\
\text { Minerale Ltda.. }\end{array}$ \\
\hline 47 & $05 / 2011$ & $\begin{array}{l}\text { Residencial Spazio } \\
\text { Acrópolis }\end{array}$ & $\begin{array}{l}\text { Minha Casa Minha } \\
\text { Vida III (CEF) }\end{array}$ & $\begin{array}{l}248 \\
\text { apartamentos }\end{array}$ & $\begin{array}{l}\text { Faixa } 3 \text { do MCMV. Constr: MRV } \\
\text { Engenharia e Participações SA. }\end{array}$ \\
\hline 48 & $09 / 2011$ & $\begin{array}{l}\text { Residencial } \\
\text { Campos Verdes }\end{array}$ & $\begin{array}{l}\text { Minha Casa Minha } \\
\text { Vida II (CEF) }\end{array}$ & $\begin{array}{l}76 \\
\text { apartamentos }\end{array}$ & $\begin{array}{l}\text { Faixa } 2 \text { do MCMV. Construtora: } \\
\text { SEGAL Ltda.. }\end{array}$ \\
\hline 49 & $12 / 2011$ & $\begin{array}{l}\text { Condomínio } \\
\text { Copacabana }\end{array}$ & $\begin{array}{l}\text { Minha Casa Minha } \\
\text { Vida III (CEF) }\end{array}$ & $\begin{array}{l}36 \\
\text { apartamentos }\end{array}$ & $\begin{array}{l}\text { Faixa } 3 \text { do MCMV. Construtora: } \\
\text { Quilombo Consultoria, Empreend. e } \\
\text { Participação Ltda.. }\end{array}$ \\
\hline 50 & $06 / 2012$ & $\begin{array}{l}\text { Residencial Canto } \\
\text { das Águas }\end{array}$ & $\begin{array}{l}\text { Minha Casa Minha } \\
\text { Vida II (CEF) }\end{array}$ & $\begin{array}{l}182 \\
\text { apartamentos }\end{array}$ & $\begin{array}{l}\text { Faixa } 2 \text { do MCMV. Construtora: CAL } \\
\text { Participaç̃̃es e Empreendimentos } \\
\text { Imobiliários e Agropecuária Ltda.. }\end{array}$ \\
\hline 51 & 09/2012 & $\begin{array}{l}\text { Residencial Colina } \\
\text { Azul }\end{array}$ & $\begin{array}{l}\text { Minha Casa Minha } \\
\text { Vida III (CEF) }\end{array}$ & $\begin{array}{l}124 \\
\text { apartamentos }\end{array}$ & $\begin{array}{l}\text { Faixa } 3 \text { do MCMV. Construtora: } \\
\text { SEGAL Ltda.. }\end{array}$ \\
\hline 52 & $01 / 2013$ & Spazio Aramis & $\begin{array}{l}\text { Minha Casa Minha } \\
\text { Vida III (CEF) }\end{array}$ & $\begin{array}{l}320 \\
\text { apartamentos }\end{array}$ & $\begin{array}{l}\text { Faixa } 3 \text { do MCMV. Construtora: } \\
\text { MRV Engenharia e Participações SA. }\end{array}$ \\
\hline 53 & $02 / 2013$ & $\begin{array}{l}\text { Cond. Res. Jardim } \\
\text { Botânico }\end{array}$ & $\begin{array}{l}\text { Minha Casa Minha } \\
\text { Vida II (CEF) }\end{array}$ & $\begin{array}{l}18 \\
\text { apartamentos }\end{array}$ & $\begin{array}{l}\text { Faixa } 2 \text { do MCMV. Metro IV } \\
\text { Construtora e Incorporadora. }\end{array}$ \\
\hline 54 & $05 / 2013$ & $\begin{array}{l}\text { Cond. Res. Nova } \\
\text { Praia- módulo I }\end{array}$ & $\begin{array}{l}\text { Minha Casa Minha } \\
\text { Vida II (CEF) }\end{array}$ & $\begin{array}{l}96 \\
\text { apartamentos }\end{array}$ & $\begin{array}{l}\text { Faixa } 2 \text { do MCMV. Metro IV } \\
\text { Construtora e Incorporadora Ltda.. }\end{array}$ \\
\hline 55 & 2013 & $\begin{array}{l}\text { Parque Asteca } \\
\text { (Fase } 1 \text { e } 2 \text { ) }\end{array}$ & $\begin{array}{l}\text { MCMV III - Banco } \\
\text { do Brasil }\end{array}$ & $\begin{array}{l}896 \\
\text { apartamentos }\end{array}$ & $\begin{array}{l}\text { Faixa } 3 \text { do MCMV (448 } \\
\text { apartamentos em cada fase). Pq. } \\
\text { Asteca Incorporações SPE Ltda.. }\end{array}$ \\
\hline 56 & $12 / 2013$ & $\begin{array}{l}\text { Condomínio Res. } \\
\text { Nova Praia - } \\
\text { módulo II }^{71}\end{array}$ & $\begin{array}{l}\text { Minha Casa Minha } \\
\text { Vida II (CEF) }\end{array}$ & $\begin{array}{l}112 \\
\text { apartamentos }\end{array}$ & $\begin{array}{l}\text { Faixa } 2 \text { do MCMV. Construtora: } \\
\text { Metro IV Construtora e } \\
\text { Incorporadora Ltda.. }\end{array}$ \\
\hline & $\begin{array}{l}12 / 2013- \\
06 / 2014\end{array}$ & $\begin{array}{l}\text { Cond. São Pedro e } \\
\text { São Marcos }\end{array}$ & $\begin{array}{l}\text { Minha Casa Minha } \\
\text { Vida III (CEF) }\end{array}$ & $\begin{array}{l}48 \\
\text { apartamentos }\end{array}$ & $\begin{array}{l}\text { Faixa } 3 \text { do MCMV. Construtora: } \\
\text { Quilombo. }\end{array}$ \\
\hline 58 & $04 / 2014$ & Edifício Tatiana & $\begin{array}{l}\text { Minha Casa Minha } \\
\text { Vida II / III (CEF) }\end{array}$ & $\begin{array}{l}120 \\
\text { apartamentos }\end{array}$ & $\begin{array}{l}\text { Faixa } 2 \text { ou } 3 \text { do MCMV. } \\
\text { Construtora: Life Participações e } \\
\text { Investimentos S/A. }\end{array}$ \\
\hline 59 & $06 / 2014$ & $\begin{array}{l}\text { Cond. Res. } \\
\text { Americana I }\end{array}$ & $\begin{array}{l}\text { Minha Casa Minha } \\
\text { Vida III (CEF) }\end{array}$ & $\begin{array}{l}708 \\
\text { apartamentos }\end{array}$ & $\begin{array}{l}\text { Faixa } 3 \text { do MCMV. Construtora: HM } \\
\text { Empreend. Imobiliários SPE Ltda.. }\end{array}$ \\
\hline 60 & $09 / 2014$ & $\begin{array}{l}\text { America } \\
\text { Residence }\end{array}$ & $\begin{array}{l}\text { Minha Casa Minha } \\
\text { Vida II (CEF) }\end{array}$ & $\begin{array}{l}34 \\
\text { apartamentos }\end{array}$ & $\begin{array}{l}\text { Faixa } 2 \text { do MCMV. Construtora: } \\
\text { Sega Ltda. }\end{array}$ \\
\hline 61 & $12 / 2014$ & $\begin{array}{l}\text { Residencial } \\
\text { Araguaia }\end{array}$ & $\begin{array}{l}\text { Minha Casa Minha } \\
\text { Vida II / III (CEF) }\end{array}$ & $\begin{array}{l}28 \\
\text { apartamentos }\end{array}$ & $\begin{array}{l}\text { Faixa } 2 \text { ou } 3 \text { do MCMV. Constr.: } \\
\text { Mutti Scarazzatti construtora Ltda. }\end{array}$ \\
\hline 62 & 2014 & $\begin{array}{l}\text { Cond. Parque } \\
\text { Arkansas }\end{array}$ & $\begin{array}{l}\text { MCMV III - Banco } \\
\text { do Brasil }\end{array}$ & $\begin{array}{l}384 \\
\text { apartamentos }\end{array}$ & $\begin{array}{l}\text { Faixa } 3 \text { do MCMV. Constr.: Pq. } \\
\text { Arkansas Incorporações SPE Ltda.. }\end{array}$ \\
\hline \multicolumn{4}{|c|}{ Total de Unidades Habitacionais produzidas } & 15.144 & \\
\hline \multicolumn{4}{|c|}{ Total de casas produzidas } & 6.250 & \\
\hline \multicolumn{4}{|c|}{ Total de lotes urbanizados } & 4.666 & \\
\hline \multicolumn{4}{|c|}{ Total de apartamentos produzidos } & 4.228 & \\
\hline
\end{tabular}

71 O conjunto Nova Praia - módulo III, com 96 apartamentos (faixa 3), foi entregue em janeiro de 2015, portanto, não consta do período pesquisado. 
Tabela 7 - Dados das Habitações de Interesse Social produzidas em Artur Nogueira (19642014)

\begin{tabular}{|c|c|c|c|c|c|}
\hline \multicolumn{6}{|c|}{ Produção Habitacional de Artur Nogueira } \\
\hline & $\begin{array}{c}\text { Ano de } \\
\text { entreg } \\
\text { a }\end{array}$ & $\begin{array}{l}\text { Nome do } \\
\text { Conjunto }\end{array}$ & $\begin{array}{c}\text { Agente financeiro } \\
\text { / Parcerias }\end{array}$ & $\begin{array}{c}N^{0} \text { de } \\
\text { Unidades } \\
\text { Habitacionais }\end{array}$ & Observações \\
\hline 01 & $04 / 1981$ & \begin{tabular}{|l|} 
Jardim \\
Planalto I
\end{tabular} & $\begin{array}{l}\text { Cia. de Habitação } \\
\text { Popular de Campinas }\end{array}$ & $\begin{array}{l}66 \text { casas e } 36 \\
\text { lotes }\end{array}$ & \\
\hline 02 & 07/1982 & \begin{tabular}{|l} 
Jardim \\
Planalto II
\end{tabular} & $\begin{array}{l}\text { Município de Artur } \\
\text { Nogueira (EMDHARNO) }\end{array}$ & 144 casas & $\begin{array}{l}\text { EMDHARNO - Empresa Municipal } \\
\text { de Desenvolvimento Habitacional } \\
\text { de Artur Nogueira. }\end{array}$ \\
\hline 03 & $01 / 1983$ & \begin{tabular}{|l} 
Jardim \\
Planalto III
\end{tabular} & $\begin{array}{l}\text { Município de Artur } \\
\text { Nogueira (EMDHARNO) }\end{array}$ & $\begin{array}{l}120 \text { casas e } 33 \\
\text { lotes }\end{array}$ & $\begin{array}{l}\text { O Decreto 01/1983 aprova o } \\
\text { loteamento Jd. Planalto III de } \\
\text { casas populares, pelo sistema } \\
\text { Nosso Teto, patrocinado pela CEF e } \\
\text { com execução da EMDHARNO. }\end{array}$ \\
\hline 04 & $12 / 1987$ & $\begin{array}{l}\text { Parque Nosso } \\
\text { Lar }\end{array}$ & $\begin{array}{l}\text { Prefeitura Municipal de } \\
\text { Artur Nogueira }\end{array}$ & 161 lotes & $\begin{array}{l}\text { O Dec. 01/1987 desapropriou a } \\
\text { área. Para cada lote, a Prefeitura } \\
\text { Municipal forneceu uma planta de } \\
\text { edificação popular. }\end{array}$ \\
\hline 05 & $12 / 1988$ & $\begin{array}{l}\text { Nosso } \\
\text { Recanto }\end{array}$ & $\begin{array}{l}\text { Prefeitura Municipal de } \\
\text { Artur Nogueira }\end{array}$ & 97 lotes & $\begin{array}{l}\text { O Dec. } 117 / 1988 \text { aprovou o } \\
\text { loteamento Nosso Recanto, onde } \\
\text { foi implantado o Programa } \\
\text { Municipal de Habitação, cuja } \\
\text { criação ocorreu por meio da Lei } \\
\text { Municipal nº 1.665/1987. } \\
\end{array}$ \\
\hline 06 & $05 / 1989$ & Jardim Paraíso & $\begin{array}{l}\text { Iniciativa privada (Davoli } \\
\text { Imóveis Ltda.) e } \\
\text { Prefeitura }\end{array}$ & $\begin{array}{l}56 \text { casas e } \\
219 \text { lotes }\end{array}$ & $\begin{array}{l}\text { A Prefeitura Municipal de Artur } \\
\text { Nogueira autoriza em } 1989 \text { a } \\
\text { implantação de um conjunto } \\
\text { residencial particular, por meio de } \\
\text { uma certidão (protocolo } \\
\text { 000197/1989). }\end{array}$ \\
\hline 07 & 1990 & $\begin{array}{l}\text { Parque dos } \\
\text { Trabalhadores }\end{array}$ & $\begin{array}{l}\text { Prefeitura Municipal de } \\
\text { Artur Nogueira }\end{array}$ & 312 lotes & $\begin{array}{l}\text { O ano de } 1990 \text { refere-se à data de } \\
\text { entrega, mas o projeto ainda não } \\
\text { está regularizado (em 2014). }\end{array}$ \\
\hline 08 & 1991 & $\begin{array}{l}\text { Coração } \\
\text { Criança }\end{array}$ & $\begin{array}{l}\text { Prefeitura Municipal de } \\
\text { Artur Nogueira }\end{array}$ & 252 lotes & $\begin{array}{l}\text { A data de entrega é } 1991 \text {, mas o } \\
\text { projeto ainda não está regularizado } \\
\text { (em 2014). }\end{array}$ \\
\hline 09 & $06 / 1994$ & \begin{tabular}{|l} 
Jardim Vista \\
Alegre
\end{tabular} & C.D.H.U. & $\begin{array}{l}300 \text { casas e } \\
1 \text { lote }\end{array}$ & \\
\hline 10 & 1996 & $\begin{array}{l}\text { Pq. Res. } \\
\text { Nosso Chão }\end{array}$ & $\begin{array}{l}\text { Município de Artur } \\
\text { Nogueira }\end{array}$ & 149 lotes & $\begin{array}{l}\text { A Lei Complementar no } 51 / 1996 \\
\text { incorpora o imóvel no Programa } \\
\text { Municipal de Habitação. A data de } \\
\text { entrega é 1996, mas o projeto não } \\
\text { está regularizado (2014). }\end{array}$ \\
\hline 11 & 06/1997 & $\begin{array}{l}\text { Jardim } \\
\text { Carolina }\end{array}$ & \begin{tabular}{|l|} 
Iniciativa privada \\
(Consran Eng. e Constr. \\
Ranciaro Ltda.)
\end{tabular} & $\begin{array}{l}218 \text { lotes e } \\
10 \text { casas }\end{array}$ & $\begin{array}{l}\text { A Lei no } 2.396 / 1997 \text { aprova o } \\
\text { loteamento popular em área de } \\
\text { propriedade de Izael de Fáveri. }\end{array}$ \\
\hline 12 & $01 / 2000$ & Jardim Leonor & \begin{tabular}{|l|} 
Iniciativa Privada e \\
Companhia Regional de \\
Habitações de Interesse \\
Social de Araçatuba. \\
\end{tabular} & $\begin{array}{l}131 \text { lotes e } \\
100 \text { casas }\end{array}$ & $\begin{array}{l}\text { O Projeto foi realizado na área de } \\
\text { propriedade de Celso Capato, pela } \\
\text { Companhia Regional de Habitações } \\
\text { de Interesse Social de Araçatuba. }\end{array}$ \\
\hline \multicolumn{4}{|c|}{ Total de Unidades Habitacionais produzidas } & 2.405 & \\
\hline \multicolumn{4}{|c|}{ Total de casas produzidas } & 796 & \\
\hline \multicolumn{4}{|c|}{ Total de lotes urbanizados produzidos } & 1.609 & \\
\hline \multicolumn{4}{|c|}{ Total de apartamentos produzidos } & 0 & \\
\hline
\end{tabular}


Tabela 8 - Dados das Habitações de Interesse Social produzidas em Campinas (1964-2014)

\begin{tabular}{|c|c|c|c|c|c|}
\hline \multicolumn{6}{|c|}{ Produção Habitacional de Campinas } \\
\hline & $\begin{array}{l}\text { Ano de } \\
\text { entrega }\end{array}$ & $\begin{array}{l}\text { Nome do } \\
\text { Conjunto }\end{array}$ & $\begin{array}{l}\text { Agente } \\
\text { financeiro } \\
\text { / Parcerias }\end{array}$ & $\begin{array}{c}\text { No de } \\
\text { Unidades } \\
\text { Habitacionais }\end{array}$ & Observações \\
\hline 01 & 1966 & Vila Rica & COHAB Campinas & 487 casas & \\
\hline 02 & 1967 & $\begin{array}{l}\text { Castelo Branco } \\
1^{\mathrm{a}} \text { e } 2^{\mathrm{a}}\end{array}$ & COHAB Campinas & 1.112 casas & $\begin{array}{l}\text { Foi implantado em duas etapas, sendo } \\
\text { de, respectivamente, } 668 \text { e } 444 \\
\text { unidades habitacionais. }\end{array}$ \\
\hline 03 & 1969 & $\begin{array}{l}\text { Conj. Vila Boa } \\
\text { Vista }\end{array}$ & COHAB Campinas & 1.534 casas & \\
\hline 04 & 1969 & $\begin{array}{l}\text { Santana I } \\
\text { (Sousas) }\end{array}$ & COHAB Campinas & 204 casas & \\
\hline 05 & 1970 & Costa e Silva & COHAB Campinas & 1.531 casas & \\
\hline 06 & 1970 & $\begin{array}{l}\text { Trinta e um de } \\
\text { Março }\end{array}$ & COHAB Campinas & 546 casas & \\
\hline 07 & 1972 & Campos Sales & COHAB Campinas & 350 casas & \\
\hline 08 & 1973 & Parque Itália & COHAB Campinas & 54 casas & \\
\hline 09 & 1973 & $\begin{array}{l}\text { Terrenos } \\
\text { Diversos }\end{array}$ & COHAB Campinas & 267 casas & $\begin{array}{l}\text { Proprietários de terrenos particulares } \\
\text { procuraram a COHAB Campinas e a } \\
\text { mesma doou o projeto, quando era de } \\
\text { interesse, e realizou o financiamento } \\
\text { para casas particulares. Portanto, as } \\
\text { casas estão dispersas pela cidade e } \\
\text { não foi possível realizar o } \\
\text { MAPEAMENTO. }\end{array}$ \\
\hline 10 & 1973 & $\begin{array}{l}\text { Miguel Vicente } \\
\text { Cury }\end{array}$ & COHAB Campinas & 766 casas & \\
\hline 11 & 1973 & Orozimbo Maia & COHAB Campinas & 268 casas & \\
\hline 12 & 1974 & $\begin{array}{l}\text { Júlio de } \\
\text { Mesquita Filho }\end{array}$ & COHAB Campinas & $\begin{array}{l}532 \\
\text { apartamentos }\end{array}$ & \\
\hline 13 & 1976 & $\begin{array}{l}\text { Padre M. } \\
\text { Nóbrega }\end{array}$ & COHAB Campinas & 254 casas & $1^{a}$ etapa \\
\hline 14 & 1976 & $\begin{array}{l}\text { Perseu Leite } \\
\text { de Barros }\end{array}$ & COHAB Campinas & 446 casas & \\
\hline 15 & 1978 & $\begin{array}{l}\text { Padre M. } \\
\text { Nóbrega }\end{array}$ & COHAB Campinas & $\begin{array}{l}448 \\
\text { apartamentos e } \\
842 \text { casas } \\
\end{array}$ & $2^{a}$ etapa \\
\hline 16 & 1980 & $\begin{array}{l}\text { Santana II e } \\
\text { III (Sousas) }\end{array}$ & COHAB Campinas & 104 casas & $\begin{array}{l}\text { O Santana II tem } 80 \text { casas e o } \\
\text { Santana III, } 24 \text { casas. }\end{array}$ \\
\hline 17 & 1980 & Padre Anchieta & COHAB Campinas & 2.492 casas & \\
\hline 18 & 1981 & Padre Anchieta & COHAB Campinas & $\begin{array}{l}1.072 \\
\text { apartamentos }\end{array}$ & \\
\hline 19 & 1981 & DIC I & $\begin{array}{l}\text { COHAB Campinas } \\
\text { e Profilurb } \\
\text { (Programa } \\
\text { Federal) }\end{array}$ & $\begin{array}{l}535 \text { casas e } 506 \\
\text { embriões (casas) }\end{array}$ & $\begin{array}{l}\text { As casas foram realizadas pela } \\
\text { COHAB, enquanto os embriões, pela } \\
\text { COHAB e Profilurb. Foram entregues } \\
\text { embriões de casas (um cômodo e } \\
\text { banheiro) e uma planta para } \\
\text { ampliação. }\end{array}$ \\
\hline 20 & 1981 & DIC II & COHAB Campinas & 433 casas & \\
\hline 21 & 1982 & DIC I & COHAB Campinas & $\begin{array}{l}624 \\
\text { apartamentos }\end{array}$ & \\
\hline 22 & 1982 & DIC II & COHAB Campinas & $\begin{array}{l}288 \\
\text { apartamentos }\end{array}$ & \\
\hline 23 & 1982 & $\begin{array}{l}\text { Padre M. } \\
\text { Nóbrega }\end{array}$ & COHAB Campinas & $\begin{array}{l}480 \\
\text { apartamentos }\end{array}$ & $\begin{array}{l}\text { Esses apartamentos são a } 2^{a} \text { etapa do } \\
\text { conjunto. }\end{array}$ \\
\hline
\end{tabular}




\begin{tabular}{|c|c|c|c|c|c|}
\hline \multicolumn{6}{|c|}{ Produção Habitacional de Campinas } \\
\hline & $\begin{array}{l}\text { Ano de } \\
\text { entrega }\end{array}$ & $\begin{array}{l}\text { Nome do } \\
\text { Conjunto }\end{array}$ & $\begin{array}{l}\text { Agente } \\
\text { financeiro } \\
\text { /Parcerias }\end{array}$ & $\begin{array}{c}N^{0} \text { de } \\
\text { Unidades } \\
\text { Habitacionais }\end{array}$ & Observações \\
\hline 24 & 1984 & $\begin{array}{l}\text { DIC III - Rui } \\
\text { Novaes }\end{array}$ & COHAB Campinas & $\begin{array}{l}332 \text { casas e } 300 \\
\text { apartamentos }\end{array}$ & Totalizam 632 unidades habitacionais. \\
\hline 25 & 1985 & $\begin{array}{l}\text { DIC IV-Lech } \\
\text { Walesa }\end{array}$ & COHAB Campinas & $\begin{array}{l}318 \text { casas e } 352 \\
\text { apartamentos }\end{array}$ & Totalizam 670 unidades habitacionais. \\
\hline 26 & 1986 & $\begin{array}{l}\text { Parque Itajaí } \\
1^{\text {a fase }}\end{array}$ & COHAB Campinas & 556 casas & \\
\hline 27 & 1990 & $\begin{array}{l}\text { DIC V - 1a } \\
\text { fase }\end{array}$ & COHAB Campinas & $\begin{array}{l}443 \text { casas e } 480 \\
\text { apartamentos }\end{array}$ & Totalizam 923 unidades habitacionais. \\
\hline 28 & 1990 & DIC VI & COHAB Campinas & $\begin{array}{l}1.024 \text { casas, } 720 \\
\text { apartamentos e } \\
17 \text { lotes }\end{array}$ & $\begin{array}{l}\text { Posteriormente, em 2006, } 13 \\
\text { moradores obtiveram o PSH } \\
\text { (Programa de Subsídio Habitacional do } \\
\text { Gov. Federal) - modalidade aquisição. } \\
\text { O DIC VI totaliza } 1.761 \text { unidades. }\end{array}$ \\
\hline 29 & 1990 & $\begin{array}{l}\text { Parque Itajaí } \\
2^{\mathrm{a}} \text { fase }\end{array}$ & COHAB Campinas & $\begin{array}{l}281 \text { casas e } 200 \\
\text { apartamentos }\end{array}$ & Totalizam 481 unidades habitacionais. \\
\hline 30 & 1990 & $\begin{array}{l}\text { Parque da } \\
\text { Floresta } 1^{a}\end{array}$ & $\begin{array}{l}\text { COHAB Campinas } \\
\text { e PSH }\end{array}$ & $\begin{array}{l}402 \text { embriões } \\
\text { (casas) }\end{array}$ & $\begin{array}{l}\text { Foram entregues embriões de casas } \\
\text { (um cômodo + banheiro) e uma } \\
\text { planta para ampliação. } \\
\text { Posteriormente, alguns moradores } \\
\text { adquiriram o PSH para complementar } \\
\text { o pagamento ou para ampliar o } \\
\text { embrião. }\end{array}$ \\
\hline 31 & 1993 & Vida Nova & COHAB Campinas & $\begin{array}{l}2.304 \text { lotes } \\
\text { urbanizados }\end{array}$ & $\begin{array}{l}\text { Posteriormente, mais de mil } \\
\text { moradores adquiriram o PSH } \\
\text { (Programa de Subsídio Habitacional do } \\
\text { governo federal). }\end{array}$ \\
\hline 32 & 1993 & $\begin{array}{l}\text { DIC V - } 2^{\mathrm{a}} \\
\text { fase }\end{array}$ & COHAB Campinas & $\begin{array}{l}85 \text { lotes } \\
\text { urbanizados }\end{array}$ & \\
\hline 33 & 1993 & $\begin{array}{l}\text { DIC V - } 3^{a} \\
\text { fase }\end{array}$ & COHAB Campinas & $\begin{array}{l}271 \text { lotes } \\
\text { urbanizados }\end{array}$ & $\begin{array}{l}\text { No DIC V ( } 2^{a} \text { a } 4^{a} \text { fase), assim como } \\
\text { no Parque Itajaí ( } 3^{a} \text { e } 4^{a} \text { fase), as }\end{array}$ \\
\hline 34 & 1993 & $\begin{array}{l}\text { DIC V - } 4^{a} \\
\text { fase }\end{array}$ & COHAB Campinas & $\begin{array}{l}376 \text { lotes } \\
\text { urbanizados }\end{array}$ & $\begin{array}{l}\text { casas foram entregues ainda em } \\
\text { processo de construção, inacabadas. }\end{array}$ \\
\hline 35 & 1993 & $\begin{array}{l}\text { Parque Itajaí - } \\
\text { 3a fase }\end{array}$ & COHAB Campinas & $\begin{array}{l}308 \text { lotes } \\
\text { urbanizados }\end{array}$ & $\begin{array}{l}\text { Decidiu-se, na sistematizaçao das } \\
\text { informações, considerar a entrega de }\end{array}$ \\
\hline 36 & 1993 & $\begin{array}{l}\text { Parque Itajaí - } \\
\text { 4a fase }^{\text {a fas }}\end{array}$ & COHAB Campinas & $\begin{array}{l}383 \text { lotes } \\
\text { urbanizados }\end{array}$ & \\
\hline 37 & 1994 & Boa Vista I & COHAB Campinas & $\begin{array}{l}91 \text { lotes } \\
\text { urbanizados }\end{array}$ & \\
\hline 38 & 1994 & Boa Vista II & COHAB Campinas & $\begin{array}{l}234 \text { lotes } \\
\text { urbanizados }\end{array}$ & \\
\hline 39 & 1994 & $\begin{array}{l}\text { DIC V - 2a } \\
\text { fase /Zumbi } \\
\text { dos Palmares }\end{array}$ & COHAB Campinas & $\begin{array}{l}56 \text { lotes } \\
\text { urbanizados }\end{array}$ & $\begin{array}{l}\text { Posteriormente, } 48 \text { moradores } \\
\text { obtiveram o Programa de Subsídio } \\
\text { Habitacional (PSH do gov. federal). }\end{array}$ \\
\hline 40 & 1994 & $\begin{array}{l}\text { DIC V - 4a } \\
\text { fase }\end{array}$ & COHAB Campinas & $\begin{array}{l}69 \text { lotes } \\
\text { urbanizados }\end{array}$ & \\
\hline
\end{tabular}

\footnotetext{
${ }^{72}$ Ver mais informações em "Casas vendidas em processo de construção | município de Campinas" (p.
} 117). 


\begin{tabular}{|c|c|c|c|c|c|}
\hline \multicolumn{6}{|c|}{ Produção Habitacional de Campinas } \\
\hline & $\begin{array}{l}\text { Ano de } \\
\text { entrega }\end{array}$ & $\begin{array}{l}\text { Nome do } \\
\text { Conjunto }\end{array}$ & $\begin{array}{c}\text { Agente } \\
\text { financeiro } \\
\text { / Parcerias }\end{array}$ & \begin{tabular}{|c|}
$N^{0}$ de \\
Unidades \\
Habitacionais
\end{tabular} & Observações \\
\hline 41 & 1996 & $\begin{array}{l}\text { Parque da } \\
\text { Floresta }\end{array}$ & COHAB Campinas & $\begin{array}{l}1.301 \text { lotes } \\
\text { urbanizados }\end{array}$ & $\begin{array}{l}\text { Posteriormente, alguns moradores } \\
\text { adquiriram o PSH (Programa de } \\
\text { Subsídio Habitacional do governo } \\
\text { federal) para complementar o } \\
\text { pagamento ou para construir. }\end{array}$ \\
\hline 42 & 1996 & $\begin{array}{l}\text { Parque Itajaí } \\
/ 3^{a} \text { fase }\end{array}$ & COHAB Campinas & $\begin{array}{l}54 \text { lotes } \\
\text { urbanizados }\end{array}$ & \\
\hline 43 & 1996 & $\begin{array}{l}\text { Parque Itajaí } \\
\text { /4a fase }\end{array}$ & COHAB Campinas & $\begin{array}{l}117 \text { lotes } \\
\text { urbanizados }\end{array}$ & \\
\hline 44 & 1996 & Padre Anchieta & COHAB Campinas & $\begin{array}{l}71 \text { lotes } \\
\text { urbanizados }\end{array}$ & \\
\hline 45 & 09/1996 & \begin{tabular}{|l|} 
Arlete Cardoso \\
Lins Teixeira \\
/Campinas C \\
(UNICAMP)
\end{tabular} & $\mathrm{CDHU}^{73}$ & 84 casas & \\
\hline 46 & $12 / 1997$ & $\begin{array}{l}\text { Arlete Cardoso } \\
\text { Lins Teixeira } \\
\text { /Campinas C } \\
\text { (UNICAMP) }\end{array}$ & $\mathrm{CDHU}$ & 78 apartamentos & \\
\hline 47 & $12 / 1997$ & $\begin{array}{l}\text { Arlete Cardoso } \\
\text { Lins Teixeira } \\
\text { /Campinas C } \\
\text { (UNICAMP) }\end{array}$ & $\mathrm{CDHU}$ & $\begin{array}{l}71 \text { sobrados } \\
\text { (casas) }\end{array}$ & \\
\hline 48 & 1998 & Padre Anchieta & COHAB Campinas & 2 casas & $\begin{array}{l}\text { Casa Idoso-Quadra F5- L33 e L33A } \\
\text { NÃO MAPEADAS. }\end{array}$ \\
\hline 49 & 1998 & Jardim Telesp & COHAB Campinas & $\begin{array}{l}306 \text { lotes } \\
\text { urbanizados }\end{array}$ & $\begin{array}{l}\text { Posteriormente, } 248 \text { moradores } \\
\text { adquiriram o PSH (gov. federal), } \\
\text { subsídio para complementar a compra } \\
\text { ou para construir sua unidade } \\
\text { habitacional. }\end{array}$ \\
\hline 50 & 1998 & Vila Esperança & COHAB Campinas & $\begin{array}{l}315 \text { lotes } \\
\text { urbanizados }\end{array}$ & $\begin{array}{l}\text { Embora o número de lotes seja } \\
\text { divergente da quantidade que consta } \\
\text { no site da COHAB, o número de } 315 \\
\text { lotes urbanizados foi obtido em } \\
\text { reunião com técnico e consulta à } \\
\text { planta da COHAB. Acredita-se que, do } \\
\text { total de } 582 \text { lotes urbanizados (valor } \\
\text { que consta no site), alguns lotes foram } \\
\text { empreendidos posteriormente. }\end{array}$ \\
\hline 51 & 01/1999 & $\begin{array}{l}\text { Santa Clara } \\
\text { d'Oeste } \\
\text { /Campinas H }\end{array}$ & $\mathrm{CDHU}$ & $\begin{array}{l}620 \\
\text { apartamentos }\end{array}$ & Programa Chamamento Empresarial \\
\hline
\end{tabular}

${ }^{73}$ As informações sobre número de unidades, data e localização dos empreendimentos foram obtidas diretamente na CDHU, exceto os dados em observações e o primeiro nome do conjunto (obtidos no PLHIS de Campinas). 


\begin{tabular}{|c|c|c|c|c|c|}
\hline & \multicolumn{5}{|c|}{ Produção Habitacional de Campinas } \\
\hline & $\begin{array}{l}\text { Ano de } \\
\text { entrega }\end{array}$ & $\begin{array}{l}\text { Nome do } \\
\text { Conjunto }\end{array}$ & $\begin{array}{l}\text { Agente } \\
\text { financeiro } \\
\text { / Parcerias }\end{array}$ & \begin{tabular}{|c|}
$N^{\circ}$ de \\
Unidades \\
Habitacionais
\end{tabular} & Observações \\
\hline 52 & 1999 & $\begin{array}{l}\text { Vila Esperança } \\
\text { PROCEN }\end{array}$ & $\begin{array}{l}\text { Prefeitura } \\
\text { Municipal de } \\
\text { Campinas e } \\
\text { PROCEN }\end{array}$ & 533 casas & $\begin{array}{l}\text { PROCEN: Programa de Combate às } \\
\text { Enchentes. } \\
\text { As informações como ano e número } \\
\text { de casas foram estimadas por técnicos } \\
\text { da COHAB Campinas, pois, segundo a } \\
\text { Coordenação de Planejamento } \\
\text { Habitacional da Secretaria de } \\
\text { Habitação (SEHAB) de Campinas, não } \\
\text { há arquivos sobre o empreendimento } \\
\text { na SEHAB e os técnicos que } \\
\text { trabalharam com o projeto se } \\
\text { aposentaram. Portanto, os dados são } \\
\text { aproximações a partir de desenhos } \\
\text { existentes na COHAB Campinas. }\end{array}$ \\
\hline 53 & 1999 & $\begin{array}{l}\text { DIC V - 2a } \\
\text { fase /Jd. } \\
\text { Aruanã }\end{array}$ & COHAB Campinas & $\begin{array}{l}96 \text { lotes } \\
\text { urbanizados }\end{array}$ & \begin{tabular}{|l} 
Posteriormente, 73 moradores \\
obtiveram o Programa de Subsídio \\
Habitacional (PSH - gov. federal).
\end{tabular} \\
\hline 54 & 1999 & $\begin{array}{l}\text { DIC V } 3^{a} \text { fase } \\
\text { /Jd. Marighella }\end{array}$ & COHAB Campinas & $\begin{array}{l}181 \text { lotes } \\
\text { urbanizados }\end{array}$ & $\begin{array}{l}\text { Posteriormente à entrega dos lotes, } \\
123 \text { moradores obtiveram subsídio } \\
\text { federal para moradias (PSH). }\end{array}$ \\
\hline 55 & 1999 & $\begin{array}{l}\text { Jardim São } \\
\text { Luís }\end{array}$ & COHAB Campinas & $\begin{array}{l}676 \text { lotes } \\
\text { urbanizados }\end{array}$ & $\begin{array}{l}\text { Posteriormente, } 614 \text { moradores } \\
\text { adquiriram o PSH (modalidade } \\
\text { aquisição). }\end{array}$ \\
\hline 56 & 1999 & $\begin{array}{l}\text { Jardim São } \\
\text { José }\end{array}$ & COHAB Campinas & $\begin{array}{l}750 \text { lotes } \\
\text { urbanizados }\end{array}$ & $\begin{array}{l}\text { Posteriormente, } 579 \text { moradores } \\
\text { obtiveram recursos do PSH (Programa } \\
\text { de Subsídio Habitacional do governo } \\
\text { federal) para as moradias. }\end{array}$ \\
\hline 57 & 1999 & $\begin{array}{l}\text { Jardim } \\
\text { Conceição } \\
\text { (Sousas) }\end{array}$ & COHAB Campinas & $\begin{array}{l}120 \text { lotes } \\
\text { urbanizados }\end{array}$ & $\begin{array}{l}\text { Posteriormente, } 88 \text { moradores } \\
\text { adquiriram o PSH para construir a } \\
\text { unidade ou complementar o } \\
\text { pagamento. }\end{array}$ \\
\hline 58 & $06 / 2000$ & $\begin{array}{l}\text { Arlete Cardoso } \\
\text { Lins Teixeira } \\
\text { /Campinas C3 } \\
\end{array}$ & CDHU & 96 apartamentos & \\
\hline 59 & $10 / 2001$ & \begin{tabular}{|l|} 
Recanto da \\
Fortuna / \\
Campinas I \\
\end{tabular} & $\mathrm{CDHU}$ & $\begin{array}{l}160 \\
\text { apartamentos }\end{array}$ & Programa Mutirão (associativo) \\
\hline 60 & $04 / 2003$ & $\begin{array}{l}\text { Edwvaldo Orsi } \\
\text { /Campinas } \\
\text { E13, E14, E15, } \\
\text { E16, E17, E18 } \\
\end{array}$ & CDHU & $\begin{array}{l}2.340 \\
\text { apartamentos }\end{array}$ & Programa Sonho Meu \\
\hline 61 & 2004 & $\begin{array}{l}\text { Vila Esperança } \\
1 \text { e } 3\end{array}$ & $\begin{array}{l}\text { PSH (Programa de } \\
\text { Subsídio } \\
\text { Habitacional) e } \\
\text { COHAB Campinas }\end{array}$ & 125 casas & $\begin{array}{l}\text { O número de } 125 \text { casas refere-se ao } \\
\text { que consta no site da COHAB, como } \\
\text { Vila Esperança } 1(109 \mathrm{UH}) \text { e Vila } \\
\text { Esperança } 3(16 \mathrm{UH}) \text {, totalizando } 125 \\
\text { casas. Valores confirmados em planta } \\
\text { da COHAB Campinas. } \\
\text { O PSH é um recurso do governo } \\
\text { federal. }\end{array}$ \\
\hline 62 & 2004 & $\begin{array}{l}\text { Vila Georgina/ } \\
\text { Antônio da } \\
\text { Costa Santos }\end{array}$ & $\begin{array}{l}\text { Prefeitura de } \\
\text { Campinas e } \\
\text { COHAB }\end{array}$ & 64 apartamentos & $\begin{array}{l}\text { O projeto e a fiscalização são da } \\
\text { COHAB Campinas, enquanto os } \\
\text { recursos são da Prefeitura Municipal } \\
\text { de Campinas. }\end{array}$ \\
\hline
\end{tabular}




\begin{tabular}{|c|c|c|c|c|c|}
\hline \multicolumn{6}{|c|}{ Produção Habitacional de Campinas } \\
\hline & $\begin{array}{l}\text { Ano de } \\
\text { entrega }\end{array}$ & $\begin{array}{l}\text { Nome do } \\
\text { Conjunto }\end{array}$ & $\begin{array}{l}\text { Agente } \\
\text { financeiro } \\
\text { / Parcerias }\end{array}$ & $\begin{array}{c}\text { No de } \\
\text { Unidades } \\
\text { Habitacionais }\end{array}$ & Observações \\
\hline 63 & 2004 & $\begin{array}{l}\text { Parque da } \\
\text { Floresta }\end{array}$ & $\begin{array}{l}\text { PSH (Programa de } \\
\text { Subsídio } \\
\text { Habitacional) e } \\
\text { COHAB Campinas }\end{array}$ & 23 casas & $\begin{array}{l}\text { O loteamento foi realizado pela } \\
\text { COHAB; já a construção das casas foi } \\
\text { realizada a partir do PSH (Programa } \\
\text { de Subsídio Habitacional do governo } \\
\text { federal). As casas não foram } \\
\text { mapeadas, pois estão localizadas em } \\
\text { diversas quadras do loteamento Pq. da } \\
\text { Floresta. }\end{array}$ \\
\hline 64 & 2004 & $\begin{array}{l}\text { Núcleo } \\
\text { Residencial } \\
\text { São José }\end{array}$ & $\begin{array}{l}\text { PSH (Programa de } \\
\text { Subsídio } \\
\text { Habitacional) e } \\
\text { COHAB Campinas }\end{array}$ & 24 casas & $\begin{array}{l}\text { As casas não foram mapeadas, pois } \\
\text { estão localizadas em diversas áreas do } \\
\text { loteamento São José, realizado pela } \\
\text { COHAB. Para a construção das casas, } \\
\text { houve o PSH (Programa de Subsídio } \\
\text { Habitacional) do governo federal. }\end{array}$ \\
\hline 65 & 2004 & $\begin{array}{l}\text { Núcleo Getúlio } \\
\text { Vargas }\end{array}$ & $\begin{array}{l}\text { PSH (CEF), } \\
\text { Prefeitura de } \\
\text { Campinas e } \\
\text { COHAB }\end{array}$ & 11 casas & $\begin{array}{l}\text { As casas não foram mapeadas, pois } \\
\text { não foi possível obter a planta junto à } \\
\text { COHAB. O Programa de Subsídio } \\
\text { Habitacional (PSH) do governo federal } \\
\text { ocorreu por meio da Caixa Econômica } \\
\text { Federal (CEF). A COHAB Campinas } \\
\text { realizou o projeto em terreno público. }\end{array}$ \\
\hline 66 & 2004 & $\begin{array}{l}\text { Núcleo } \\
\text { Residencial } \\
\text { Gênesis }\end{array}$ & $\begin{array}{l}\text { PSH (CEF), } \\
\text { Prefeitura de } \\
\text { Campinas e } \\
\text { COHAB Campinas }\end{array}$ & 27 casas & \\
\hline 67 & 2005 & $\begin{array}{l}\text { Núcleo } \\
\text { Residencial } \\
\text { Gênesis } 2\end{array}$ & $\begin{array}{l}\text { PSH (CEF), } \\
\text { Prefeitura de } \\
\text { Campinas e } \\
\text { COHAB }\end{array}$ & 19 casas & $\begin{array}{l}\text { O PSH (Programa de Subsídio } \\
\text { Habitacional) do governo federal } \\
\text { ocorreu por meio da Caixa Econômica } \\
\text { Federal. A COHAB Campinas realizou }\end{array}$ \\
\hline 68 & 2005 & $\begin{array}{l}\text { Núcleo Getúlio } \\
\text { Vargas }\end{array}$ & $\begin{array}{l}\text { PSH (CEF), } \\
\text { Prefeitura de } \\
\text { Campinas e } \\
\text { COHAB }\end{array}$ & 33 casas & \\
\hline 69 & 2005 & $\begin{array}{l}\text { Residencial } \\
\text { Olimpia }\end{array}$ & $\begin{array}{l}\text { COHAB Campinas } \\
\text { e PSH }\end{array}$ & 617 casas & $\begin{array}{l}\text { Dos } 617 \text { moradores, } 460 \text { também } \\
\text { obtiveram recurso federal por meio do } \\
\text { PSH (sendo } 13 \text { na modalidade } \\
\text { aquisição e } 447 \text { na modalidade } \\
\text { construção). PSH - Programa de } \\
\text { Subsídio Habitacional. }\end{array}$ \\
\hline 70 & 2005 & $\begin{array}{l}\text { Nova } \\
\text { Bandeirante } \\
\text { Residencial }\end{array}$ & $\begin{array}{l}\text { COHAB Campinas } \\
\text { e PSH }\end{array}$ & 31 casas & $\begin{array}{l}\text { Para todas as unidades, os moradores } \\
\text { obtiveram também o subsídio do } \\
\text { governo federal: PSH (Programa de } \\
\text { Subsídio Habitacional). }\end{array}$ \\
\hline 71 & $04 / 2005$ & $\begin{array}{l}\text { Condomínio } \\
\text { Res. Santos } \\
\text { Dumont I }\end{array}$ & $\begin{array}{l}\text { PAR / CEF e } \\
\text { Prefeitura de } \\
\text { Campinas }\end{array}$ & $\begin{array}{l}140 \\
\text { apartamentos }\end{array}$ & $\begin{array}{l}\text { PAR: Programa de Arrendamento } \\
\text { Residencial (gov. federal). } \\
\text { Incorporadora: HM. }\end{array}$ \\
\hline 72 & $04 / 2005$ & $\begin{array}{l}\text { Condomínio } \\
\text { Res. Santos } \\
\text { Dumont II }\end{array}$ & $\begin{array}{l}\text { PAR / CEF e } \\
\text { Prefeitura de } \\
\text { Campinas }\end{array}$ & $\begin{array}{l}160 \\
\text { apartamentos }\end{array}$ & $\begin{array}{l}\text { PAR: Programa de Arrendamento } \\
\text { Residencial (gov. federal). } \\
\text { Incorporadora: HM. }\end{array}$ \\
\hline 73 & $12 / 2005$ & $\begin{array}{l}\text { Nova } \\
\text { Aparecida } \\
\text { /CAMPINAS } \\
\text { F1/F2/F3 } \\
\end{array}$ & $\mathrm{CDHU}$ & $\begin{array}{l}1.160 \\
\text { apartamentos }\end{array}$ & Programa Sonho Meu. \\
\hline
\end{tabular}




\begin{tabular}{|c|c|c|c|c|c|}
\hline \multicolumn{6}{|c|}{ Produção Habitacional de Campinas } \\
\hline & $\begin{array}{l}\text { Ano de } \\
\text { entrega }\end{array}$ & $\begin{array}{l}\text { Nome do } \\
\text { Conjunto }\end{array}$ & $\begin{array}{l}\text { Agente } \\
\text { financeiro } \\
\text { / Parcerias }\end{array}$ & $\begin{array}{c}\mathrm{N}^{\circ} \text { de } \\
\text { Unidades } \\
\text { Habitacionais }\end{array}$ & Observações \\
\hline 74 & $03 / 2006$ & $\begin{array}{l}\text { Jd. São Bento } \\
\text { - Campinas } \\
\text { L/M }\end{array}$ & $\mathrm{CDHU}$ & 319 casas & Programa PROLAR. \\
\hline 75 & $06 / 2006$ & $\begin{array}{l}\text { Condomínio } \\
\text { Residencial } \\
\text { Villa Colorado } \\
\text { I }\end{array}$ & $\begin{array}{l}\text { PAR / CEF e } \\
\text { Prefeitura de } \\
\text { Campinas }\end{array}$ & $\begin{array}{l}192 \\
\text { apartamentos }\end{array}$ & $\begin{array}{l}\text { PAR: Programa de Arrendamento } \\
\text { Residencial (gov. federal). } \\
\text { Incorporadora: HM. }\end{array}$ \\
\hline 76 & $07 / 2006$ & $\begin{array}{l}\text { Condomínio } \\
\text { Residencial } \\
\text { Villa Colorado } \\
\text { II }\end{array}$ & $\begin{array}{l}\text { PAR / CEF e } \\
\text { Prefeitura de } \\
\text { Campinas }\end{array}$ & $\begin{array}{l}144 \\
\text { apartamentos }\end{array}$ & $\begin{array}{l}\text { PAR: Programa de Arrendamento } \\
\text { Residencial (gov. federal). } \\
\text { Incorporadora: HM. }\end{array}$ \\
\hline 77 & $07 / 2006$ & $\begin{array}{l}\text { Condomínio } \\
\text { Res. Villa } \\
\text { Colorado III }\end{array}$ & $\begin{array}{l}\text { PAR / CEF e } \\
\text { Prefeitura de } \\
\text { Campinas }\end{array}$ & $\begin{array}{l}112 \\
\text { apartamentos }\end{array}$ & $\begin{array}{l}\text { PAR: Programa de Arrendamento } \\
\text { Residencial (gov. federal). } \\
\text { Incorporadora: HM. }\end{array}$ \\
\hline 78 & $11 / 2006$ & $\begin{array}{l}\text { Condomínio } \\
\text { Residencial } \\
\text { Samambaia }\end{array}$ & $\begin{array}{l}\text { PAR /CEF e } \\
\text { Prefeitura de } \\
\text { Campinas }\end{array}$ & $\begin{array}{l}180 \\
\text { apartamentos }\end{array}$ & $\begin{array}{l}\text { PAR: Programa de Arrendamento } \\
\text { Residencial (gov. federal). } \\
\text { Incorporadora: Menin Const. }\end{array}$ \\
\hline 79 & 2006 & $\begin{array}{l}\text { Núcleo } \\
\text { Residencial } \\
\text { Guaraçaí }\end{array}$ & $\begin{array}{l}\text { PSH (por meio da } \\
\text { Caixa Econômica } \\
\text { Federal), } \\
\text { Prefeitura de } \\
\text { Campinas e } \\
\text { COHAB Campinas }\end{array}$ & $\begin{array}{l}40 \text { casas } \\
\text { (sobrados) }\end{array}$ & $\begin{array}{l}\text { Em } 2001 \text { é assinado, entre prefeitura e } \\
\text { COHAB-Campinas, o contrato no } 248, \\
\text { de modo que a COHAB passasse a } \\
\text { realizar projetos em áreas em que } \\
\text { ocorreria reurbanização de favelas (em } \\
\text { áreas públicas). Dessa forma, é } \\
\text { realizado pela COHAB o projeto do } \\
\text { Guaraçaí. PSH - Programa de Subsídio } \\
\text { Habitacional do governo federal. }\end{array}$ \\
\hline 80 & 2006 & $\begin{array}{l}\text { Vila Esperança } \\
2\end{array}$ & $\begin{array}{l}\text { COHAB Campinas } \\
\text { e PSH }\end{array}$ & 175 casas & $\begin{array}{l}\text { PSH - Programa de Subsídio } \\
\text { Habitacional (governo federal). São } 27 \\
\text { sobrados e } 148 \text { casas térreas. }\end{array}$ \\
\hline 81 & 2007 & $\begin{array}{l}\text { Vila Esperança } \\
4\end{array}$ & $\begin{array}{l}\text { COHAB Campinas } \\
\text { e PSH (gov. } \\
\text { Federal) }\end{array}$ & $\begin{array}{l}78 \text { casas } \\
\text { (sobrados) }\end{array}$ & $\begin{array}{l}\text { O número de sobrados diverge da } \\
\text { informação do site da COHAB, mas o } \\
\text { valor de } 78 \text { casas foi checado na } \\
\text { planta da COHAB. O PSH (Programa } \\
\text { de Subsídio Habitacional) é do } \\
\text { governo federal. }\end{array}$ \\
\hline 82 & $07 / 2007$ & $\begin{array}{l}\text { PAR II - Conj. } \\
\text { Res. Pq. São } \\
\text { Bento }\end{array}$ & $\begin{array}{l}\text { PAR / CEF e } \\
\text { Prefeitura de } \\
\text { Campinas }\end{array}$ & 351 casas & $\begin{array}{l}\text { PAR: Programa de Arrendamento } \\
\text { Residencial (gov. federal). } \\
\text { Incorporadora: Tecnosul. }\end{array}$ \\
\hline 83 & 07/2007 & $\begin{array}{l}\text { PAR II - Conj. } \\
\text { Residencial Pq. } \\
\text { São Bento II }\end{array}$ & $\begin{array}{l}\text { PAR / CEF e } \\
\text { Prefeitura de } \\
\text { Campinas }\end{array}$ & 200 casas & $\begin{array}{l}\text { PAR: Programa de Arrendamento } \\
\text { Residencial (gov. federal). } \\
\text { Incorporadora: Tecnosul. }\end{array}$ \\
\hline 84 & 2008 & $\begin{array}{l}\text { Núcleo } \\
\text { Residencial } \\
\text { Vila Brandina }\end{array}$ & $\begin{array}{l}\text { PSH (por meio da } \\
\text { Caixa Econômica } \\
\text { Federal), } \\
\text { Prefeitura de } \\
\text { Campinas e } \\
\text { COHAB }\end{array}$ & $\begin{array}{l}13 \text { casas } \\
\text { (sobrados) }\end{array}$ & $\begin{array}{l}\text { Assim como ocorre no Guaraçaí (ver } \\
\text { observações), o Vila Brandina é } \\
\text { realizado a partir do contrato } 248 \\
\text { entre prefeitura e COHAB. Assim, a } \\
\text { COHAB Campinas realizou o projeto e } \\
\text { o terreno é público e contrapartida } \\
\text { financeira. PSH - Programa de } \\
\text { Subsídio Habitacional do governo } \\
\text { federal. }\end{array}$ \\
\hline 85 & $01 / 2008$ & \begin{tabular}{|l|} 
Condomínio \\
Residencial Pq. \\
da Mata II
\end{tabular} & $\begin{array}{l}\text { PAR / CEF e } \\
\text { Prefeitura de } \\
\text { Campinas }\end{array}$ & $\begin{array}{l}416 \\
\text { apartamentos }\end{array}$ & $\begin{array}{l}\text { PAR: Programa de Arrendamento } \\
\text { Residencial (gov. federal). } \\
\text { Incorporadora: HM. }\end{array}$ \\
\hline
\end{tabular}




\begin{tabular}{|c|c|c|c|c|c|}
\hline \multicolumn{6}{|c|}{ Produção Habitacional de Campinas } \\
\hline & $\begin{array}{l}\text { Ano de } \\
\text { entrega }\end{array}$ & $\begin{array}{l}\text { Nome do } \\
\text { Conjunto }\end{array}$ & $\begin{array}{l}\text { Agente } \\
\text { financeiro } \\
\text { /Parcerias }\end{array}$ & $\begin{array}{c}\mathrm{N}^{0} \text { de } \\
\text { Unidades } \\
\text { Habitacionais }\end{array}$ & Observações \\
\hline 86 & $02 / 2008$ & $\begin{array}{l}\text { Condomínio } \\
\text { Residencial Pq. } \\
\text { da Mata I }\end{array}$ & $\begin{array}{l}\text { PAR / CEF e } \\
\text { Prefeitura de } \\
\text { Campinas }\end{array}$ & $\begin{array}{l}352 \\
\text { apartamentos }\end{array}$ & $\begin{array}{l}\text { PAR: Programa de Arrendamento } \\
\text { Residencial (gov. federal). } \\
\text { Incorporadora: HM. }\end{array}$ \\
\hline 87 & 2009 & Vida Nova & $\begin{array}{l}\text { PSH e COHAB } \\
\text { Campinas }\end{array}$ & 14 casas & $\begin{array}{l}\text { PSH - Programa de Subsídio } \\
\text { Habitacional (gov. Federal). }\end{array}$ \\
\hline 88 & 2009 & $\begin{array}{l}\text { Jardim } \\
\text { Mirassol }\end{array}$ & $\begin{array}{l}\text { COHAB Campinas } \\
\text { e PSH }\end{array}$ & 20 casas & $\begin{array}{l}\text { A área do Jardim Mirassol é } \\
\text { contrapartida de empreendimento } \\
\text { particular. Todos os moradores } \\
\text { obtiveram o subsídio do governo } \\
\text { federal (PSH). }\end{array}$ \\
\hline 89 & $\begin{array}{l}2009- \\
2010\end{array}$ & $\begin{array}{l}\text { Jardim Marisa } \\
\text { - OGU }\end{array}$ & $\begin{array}{l}\text { FNHIS (OGU), } \\
\text { Prefeitura de } \\
\text { Campinas e } \\
\text { COHAB }\end{array}$ & 313 casas & $\begin{array}{l}\text { FNHIS (Fundo Nacional de Habitação } \\
\text { de Interesse Social) do Orçamento } \\
\text { Geral da União - OGU. A COHAB } \\
\text { Campinas fez o projeto e a fiscalização } \\
\text { da obra. }\end{array}$ \\
\hline 90 & 2010 & $\begin{array}{l}\text { Vila Estação } \\
\text { Futuro }\end{array}$ & $\begin{array}{l}\text { Prefeitura } \\
\text { Municipal de } \\
\text { Campinas }\end{array}$ & $\begin{array}{l}27 \text { casas } \\
\text { (térreas e } \\
\text { sobrados) }\end{array}$ & $\begin{array}{l}\text { O terreno foi doação da União e a } \\
\text { obra foi realizada pela prefeitura. }\end{array}$ \\
\hline 91 & $01 / 2010$ & Cosmos IV-B & $\begin{array}{l}\text { Minha Casa Minha } \\
\text { Vida III }\end{array}$ & 24 casas & $\begin{array}{l}\text { Faixa } 3 \text { do MCMV. Localiza-se na } \\
\text { região Noroeste. Construtora: Mestra } \\
\text { Engenharia LTDA. }\end{array}$ \\
\hline 92 & $04 / 2010$ & Portal Dumont & $\begin{array}{l}\text { Minha Casa Minha } \\
\text { Vida II / III }\end{array}$ & 64 apartamentos & $\begin{array}{l}\text { Faixa } 2 \text { ou 3. Localiza-se na região Sul. } \\
\text { Construtora: HM Engenharia e } \\
\text { Construções S/A. }\end{array}$ \\
\hline 93 & 07/2010 & $\begin{array}{l}\text { Residencial } \\
\text { Itamambuca }\end{array}$ & $\begin{array}{l}\text { Minha Casa Minha } \\
\text { Vida III }\end{array}$ & 26 casas & $\begin{array}{l}\text { Faixa } 3 \text { do MCMV. RPZ Incorporações } \\
\text { e Empreendimentos Imobiliários Ltda. }\end{array}$ \\
\hline 94 & 09/2010 & Portal do Lago & $\begin{array}{l}\text { Programa Minha } \\
\text { Casa Minha Vida } 2\end{array}$ & 64 apart & $\begin{array}{l}\text { Faixa } 2 \text { do MCMV. Localiza-se na } \\
\text { região Sul. Construtora: Duma } \\
\text { Serviços de Engenharia Ltda. }\end{array}$ \\
\hline 95 & $10 / 2010$ & $\begin{array}{l}\text { Jd. Campineiro } \\
\text { /Campinas-J }\end{array}$ & $\mathrm{CDHU}$ & $\begin{array}{l}100 \\
\text { apartamentos }\end{array}$ & Parceria Associações e Cooperativas \\
\hline 96 & $\begin{array}{l}2010- \\
2011\end{array}$ & $\begin{array}{l}\text { Jardim Marisa } \\
\text { - PAC } \\
\text { Viracopos }\end{array}$ & $\begin{array}{l}\text { PAC (FNHIS), } \\
\text { Prefeitura de } \\
\text { Campinas e } \\
\text { COHAB }\end{array}$ & 85 casas & $\begin{array}{l}\text { A COHAB Campinas fez o projeto e a } \\
\text { fiscalização da obra. } \\
\text { PAC Viracopos: } 85 \text { casas (Jd. Marisa) e } \\
100 \text { casas (gleba B). }\end{array}$ \\
\hline 97 & $02 / 2011$ & $\begin{array}{l}\text { Central Park } \\
\text { Home Resort }\end{array}$ & $\begin{array}{l}\text { Minha Casa Minha } \\
\text { Vida III }\end{array}$ & $\begin{array}{l}262 \\
\text { apartamentos }\end{array}$ & $\begin{array}{l}\text { Faixa } 3 \text { do MCMV. Localiza-se na } \\
\text { região Sul. Construtora: Malaga } \\
\text { Empreendimentos Imobiliários Ltda. }\end{array}$ \\
\hline 98 & $02 / 2011$ & $\begin{array}{l}\text { Casas do } \\
\text { Parque }\end{array}$ & $\begin{array}{l}\text { Minha Casa Minha } \\
\text { Vida II / III }\end{array}$ & 400 casas & $\begin{array}{l}\text { Faixa } 2 \text { ou 3. Localiza-se na região } \\
\text { Sudoeste. Construtora: HM Engenharia } \\
\text { e Construções S/A. }\end{array}$ \\
\hline 99 & $05 / 2011$ & Cosmos V & $\begin{array}{l}\text { Minha Casa Minha } \\
\text { Vida II / III }\end{array}$ & 236 casas & $\begin{array}{l}\text { Faixa } 2 \text { ou } 3 . \text { Localiza-se na região } \\
\text { Noroeste. Construtora: Mestra } \\
\text { Engenharia LTDA. }\end{array}$ \\
\hline 100 & 09/2011 & $\begin{array}{l}\text { Novo } \\
\text { Horizonte I }\end{array}$ & $\begin{array}{l}\text { Minha Casa Minha } \\
\text { Vida II / III }\end{array}$ & 44 casas & $\begin{array}{l}\text { Faixa } 2 \text { ou 3. Localiza-se na região Sul. } \\
\text { Construtora: Goldfarb Incorporações e } \\
\text { Construções. }\end{array}$ \\
\hline 101 & 09/2011 & $\begin{array}{l}\text { Novo } \\
\text { Horizonte II }\end{array}$ & $\begin{array}{l}\text { Minha Casa Minha } \\
\text { Vida II / III }\end{array}$ & 46 casas & $\begin{array}{l}\text { Faixa } 2 \text { ou 3. Localiza-se na região Sul. } \\
\text { Construtora: Goldfarb Incorporações e } \\
\text { Construções. }\end{array}$ \\
\hline 102 & 09/2011 & $\begin{array}{l}\text { Novo } \\
\text { Horizonte III }\end{array}$ & $\begin{array}{l}\text { Minha Casa Minha } \\
\text { Vida II / III }\end{array}$ & 30 casas & $\begin{array}{l}\text { Faixa } 2 \text { ou 3. Localiza-se na região Sul. } \\
\text { Construtora: Goldfarb Incorporações e } \\
\text { Construções. }\end{array}$ \\
\hline
\end{tabular}




\begin{tabular}{|c|c|c|c|c|c|}
\hline \multicolumn{6}{|c|}{ Produção Habitacional de Campinas } \\
\hline & $\begin{array}{l}\text { Ano de } \\
\text { entrega }\end{array}$ & $\begin{array}{l}\text { Nome do } \\
\text { Conjunto }\end{array}$ & $\begin{array}{l}\text { Agente } \\
\text { financeiro } \\
\text { / Parcerias }\end{array}$ & $\begin{array}{c}\mathrm{N}^{\circ} \text { de } \\
\text { Unidades } \\
\text { Habitacionais }\end{array}$ & Observações \\
\hline 103 & $12 / 2011$ & $\begin{array}{l}\text { Rossi Ideal - } \\
\text { Água Bela }\end{array}$ & $\begin{array}{l}\text { Programa Minha } \\
\text { Casa Minha Vida } \\
\text { III }\end{array}$ & $\begin{array}{l}180 \\
\text { apartamentos }\end{array}$ & $\begin{array}{l}\text { Faixa } 3 \text { do MCMV. Construtora: Santa } \\
\text { Clara Tarcila Empreendimentos } \\
\text { Imobiliários Ltda. }\end{array}$ \\
\hline 104 & 2011 & $\begin{array}{l}\text { Vila Parque } \\
\text { Anhumas I e II }\end{array}$ & $\begin{array}{l}\text { PAC Anhumas, } \\
\text { Prefeitura e } \\
\text { COHAB Campinas }\end{array}$ & 180 sobrados & $\begin{array}{l}\text { Assim como ocorre no Guaraçaí (ver } \\
\text { observações), a Vila Parque Anhumas } \\
\text { é realizada a partir do contrato } 248 \\
\text { entre prefeitura e COHAB. A COHAB } \\
\text { realizou o projeto. }\end{array}$ \\
\hline 105 & $\begin{array}{l}4 / 2011- \\
3 / 2013\end{array}$ & $\begin{array}{l}\text { Residencial } \\
\text { Jardim Bassoli }\end{array}$ & $\begin{array}{l}\text { Minha Casa Minha } \\
\text { Vida I }\end{array}$ & $\begin{array}{l}2.380 \\
\text { apartamentos }\end{array}$ & $\begin{array}{l}\text { Faixa } 1 \text { do MCMV. Localiza-se na } \\
\text { Região Noroeste. Construtora: Bairro } \\
\text { Novo. }\end{array}$ \\
\hline 106 & 2012 & $\begin{array}{l}\text { Gleba B - PAC } \\
\text { Viracopos }\end{array}$ & $\begin{array}{l}\text { PAC (FNHIS), } \\
\text { Prefeitura de } \\
\text { Campinas e } \\
\text { COHAB }\end{array}$ & 100 casas & $\begin{array}{l}\text { A COHAB Campinas fez o projeto e a } \\
\text { fiscalização de obra. }\end{array}$ \\
\hline 107 & 2012 & $\begin{array}{l}\text { Núcleo Res. } \\
\text { Guaraçaí - } \\
\text { PAC Anhumas }\end{array}$ & $\begin{array}{l}\text { PAC (gov. } \\
\text { federal), } \\
\text { Prefeitura de } \\
\text { Campinas e } \\
\text { COHAB Campinas }\end{array}$ & $\begin{array}{l}30 \text { casas } \\
\text { (sobrados) }\end{array}$ & $\begin{array}{l}\text { O Núcleo Residencial Guaraçaí - PAC } \\
\text { Anhumas foi executado por meio de } \\
\text { contrato de repasse entre a União } \\
\text { Federal, por intermédio do Ministério } \\
\text { das Cidades, representada pela Caixa } \\
\text { Econômica Federal como instituição } \\
\text { financeira, e a Prefeitura Municipal de } \\
\text { Campinas. O projeto foi elaborado } \\
\text { pela COHAB Campinas. }\end{array}$ \\
\hline 108 & $02 / 2012$ & $\begin{array}{l}\text { Parque } \\
\text { Campinas }\end{array}$ & $\begin{array}{l}\text { Minha Casa Minha } \\
\text { Vida II }\end{array}$ & 730 casas & $\begin{array}{l}\text { Faixa } 2 \text { do MCMV. Localiza-se na } \\
\text { região Sudoeste. Construtora: HM } \\
\text { Engenharia e Construções S/A. }\end{array}$ \\
\hline 109 & $02 / 2012$ & Perfect Life & $\begin{array}{l}\text { Minha Casa Minha } \\
\text { Vida II /III }\end{array}$ & $\begin{array}{l}702 \\
\text { apartamentos }\end{array}$ & $\begin{array}{l}\text { Faixa } 2 \text { ou } 3 \text { do MCMV. Localiza-se na } \\
\text { região Sul. Construtora: Goldfarb } \\
\text { Incorporações e Construções. }\end{array}$ \\
\hline 110 & $03 / 2012$ & $\begin{array}{l}\text { Residencial } \\
\text { Novo Mundo - } \\
\text { módulo II }\end{array}$ & $\begin{array}{l}\text { Minha Casa Minha } \\
\text { Vida I }\end{array}$ & 110 casas & $\begin{array}{l}\text { Faixa } 1 \text { do MCMV. O Residencial Novo } \\
\text { Mundo foi um MCMV Entidades, } \\
\text { realizado pela Cooperativa } \\
\text { Habitacional de Araras, não tendo } \\
\text { envolvimento com a Secretaria de } \\
\text { Habitação de Campinas. Localiza-se na } \\
\text { Região Noroeste, e a construtora é a } \\
\text { Cooperativa Habitacional de Araras } \\
\text { (no cadastro da Caixa, o conjunto é } \\
\text { chamado de Novo Mundo módulo II). }\end{array}$ \\
\hline 1 & \begin{tabular}{|l|}
$4 / 2012-$ \\
$5 / 2012$ \\
\end{tabular} & $\begin{array}{l}\text { Residencial } \\
\text { Santa Lúcia } \\
\end{array}$ & $\begin{array}{l}\text { Minha Casa Minha } \\
\text { Vida I }\end{array}$ & $\begin{array}{l}402 \\
\text { apartamentos }\end{array}$ & $\begin{array}{l}\text { Faixa } 1 \text { do MCMV. Localiza-se na } \\
\text { Região Sudoeste. Construtora Haus. }\end{array}$ \\
\hline 11 & $\begin{array}{l}4 / 2012- \\
5 / 2012\end{array}$ & \begin{tabular}{|l|} 
Residencial \\
Porto Seguro \\
Pq. Campinas
\end{tabular} & $\begin{array}{l}\text { Minha Casa Minha } \\
\text { Vida I }\end{array}$ & $\begin{array}{l}140 \\
\text { apartamentos }\end{array}$ & $\begin{array}{l}\text { Faixa } 1 \text { do MCMV. Localiza-se na } \\
\text { Região Sudoeste. Construtora: HM } \\
\text { Engenharia. }\end{array}$ \\
\hline 113 & $05 / 2012$ & $\begin{array}{l}\text { Central View } \\
\text { Residence }\end{array}$ & $\begin{array}{l}\text { Minha Casa Minha } \\
\text { Vida III }\end{array}$ & $\begin{array}{l}400 \\
\text { apartamentos }\end{array}$ & $\begin{array}{l}\text { Faixa } 3 \text { do MCMV. Gold Alaska } \\
\text { Empreendimentos Imobiliários SPE } \\
\text { Ltda. }\end{array}$ \\
\hline 114 & $06 / 2012$ & $\begin{array}{l}\text { Rossi Ideal - } \\
\text { Horizonte }\end{array}$ & $\begin{array}{l}\text { Minha Casa Minha } \\
\text { Vida III }\end{array}$ & $\begin{array}{l}200 \\
\text { apartamentos }\end{array}$ & $\begin{array}{l}\text { Faixa } 3 \text { do MCMV. Construtora: São } \\
\text { Quirino Empreendimentos Imobiliários } \\
\text { Ltda. }\end{array}$ \\
\hline
\end{tabular}




\begin{tabular}{|c|c|c|c|c|c|}
\hline \multicolumn{6}{|c|}{ Produção Habitacional de Campinas } \\
\hline & $\begin{array}{l}\text { Ano de } \\
\text { entrega }\end{array}$ & $\begin{array}{l}\text { Nome do } \\
\text { Conjunto }\end{array}$ & $\begin{array}{l}\text { Agente } \\
\text { financeiro } \\
\text { / Parcerias }\end{array}$ & \begin{tabular}{|c|}
$N^{\circ}$ de \\
Unidades \\
Habitacionais
\end{tabular} & Observações \\
\hline 115 & $09 / 2012$ & $\begin{array}{l}\text { Bela Vista } \\
\text { Casas }\end{array}$ & $\begin{array}{l}\text { Minha Casa Minha } \\
\text { Vida III }\end{array}$ & 264 casas & $\begin{array}{l}\text { Faixa } 3 \text { do MCMV. Localiza-se na } \\
\text { região Norte. Construtora: HM } \\
\text { Engenharia e Construções S/A. }\end{array}$ \\
\hline 116 & $10 / 2012$ & Parque Celeste & $\begin{array}{l}\text { Minha Casa Minha } \\
\text { Vida II }\end{array}$ & $\begin{array}{l}144 \\
\text { apartamentos }\end{array}$ & $\begin{array}{l}\text { Faixa } 2 \text { do MCMV. Localiza-se na } \\
\text { região Leste. Construtora: MRV } \\
\text { Engenharia e Participações. }\end{array}$ \\
\hline 117 & $11 / 2012$ & Ágata Ville & $\begin{array}{l}\text { Minha Casa Minha } \\
\text { Vida III }\end{array}$ & $\begin{array}{l}356 \\
\text { apartamentos }\end{array}$ & $\begin{array}{l}\text { Faixa } 3 \text { do MCMV. Localiza-se na } \\
\text { região Sul. Construtora: MRV } \\
\text { Engenharia e Participações. }\end{array}$ \\
\hline 118 & $11 / 2012$ & $\begin{array}{l}\text { Res. Jd. } \\
\text { Ipaussurama } \\
\text { I, II e III }\end{array}$ & $\begin{array}{l}\text { Minha Casa Minha } \\
\text { Vida III }\end{array}$ & $\begin{array}{l}304 \\
\text { apartamentos }\end{array}$ & $\begin{array}{l}\text { Faixa } 3 \text { do MCMV. Construtora: HM } \\
\text { Seis Empreendimento Imobiliário SPE } \\
\text { Ltda. O Res. Jd Ipaussurama I são } 128 \\
\text { unidades, o II são } 64 \text { e o III são } 112 .\end{array}$ \\
\hline 119 & $11 / 2012$ & $\begin{array}{l}\text { Residencial } \\
\text { Torres do } \\
\text { Bonfim }\end{array}$ & $\begin{array}{l}\text { Minha Casa Minha } \\
\text { Vida II / III }\end{array}$ & $\begin{array}{l}399 \\
\text { apartamentos }\end{array}$ & $\begin{array}{l}\text { Faixas } 2 \text { ou } 3 \text { do MCMV. Construtora: } \\
\text { Gold Alaska Empreendimentos } \\
\text { Imobiliários SPE Ltda. }\end{array}$ \\
\hline 120 & $11 / 2012$ & $\begin{array}{l}\text { Rossi Ideal - } \\
\text { Água Branca }\end{array}$ & $\begin{array}{l}\text { Minha Casa Minha } \\
\text { Vida III }\end{array}$ & $\begin{array}{l}200 \\
\text { apartamentos }\end{array}$ & $\begin{array}{l}\text { Faixa } 3 \text { do MCMV. Construtora: Santa } \\
\text { Clara Tarcila Empreendimentos } \\
\text { Imobiliários Ltda. }\end{array}$ \\
\hline 121 & $12 / 2012$ & $\begin{array}{l}\text { Rossi Ideal - } \\
\text { Lírio d'Água }\end{array}$ & $\begin{array}{l}\text { Minha Casa Minha } \\
\text { Vida III }\end{array}$ & $\begin{array}{l}120 \\
\text { apartamentos }\end{array}$ & $\begin{array}{l}\text { Faixa } 3 \text { do MCMV. Construtora: Santa } \\
\text { Clara Tarcila Empreendimentos } \\
\text { Imobiliários Ltda. }\end{array}$ \\
\hline 122 & $\begin{array}{l}8 / 2012- \\
8 / 2014\end{array}$ & $\begin{array}{l}\text { Residencial } \\
\text { Sirius }\end{array}$ & $\begin{array}{l}\text { Minha Casa Minha } \\
\text { Vida I }\end{array}$ & $\begin{array}{l}2.620 \\
\text { apartamentos }\end{array}$ & $\begin{array}{l}\text { Faixa } 1 \text { do MCMV. Localiza-se na } \\
\text { Região Noroeste. Construtora: } \\
\text { Goldfarb. }\end{array}$ \\
\hline 123 & $01 / 2013$ & Topázio Ville & $\begin{array}{l}\text { Minha Casa Minha } \\
\text { Vida III }\end{array}$ & $\begin{array}{l}400 \\
\text { apartamentos }\end{array}$ & $\begin{array}{l}\text { Faixa } 3 \text { do MCMV. Localiza-se na } \\
\text { Região Sul. Construtora: MRV } \\
\text { Engenharia e Participações. }\end{array}$ \\
\hline 124 & $04 / 2013$ & $\begin{array}{l}\text { Park } \\
\text { Contemporani } \\
\text { um }\end{array}$ & $\begin{array}{l}\text { Minha Casa Minha } \\
\text { Vida II }\end{array}$ & $\begin{array}{l}240 \\
\text { apartamentos }\end{array}$ & $\begin{array}{l}\text { Faixa } 2 \text { do MCMV. Localiza-se na } \\
\text { Região Sudoeste. Construtora: MRV } \\
\text { Engenharia e Participações. }\end{array}$ \\
\hline 125 & $04 / 2013$ & Ametista Ville & $\begin{array}{l}\text { Minha Casa Minha } \\
\text { Vida III }\end{array}$ & $\begin{array}{l}320 \\
\text { apartamentos }\end{array}$ & $\begin{array}{l}\text { Faixa } 3 \text { do MCMV. Localiza-se na } \\
\text { Região Sul. Construtora: MRV } \\
\text { Engenharia e Participações. }\end{array}$ \\
\hline 126 & $04 / 2013$ & Visione (UNIP) & $\begin{array}{l}\text { Minha Casa Minha } \\
\text { Vida III }\end{array}$ & $\begin{array}{l}594 \\
\text { apartamentos }\end{array}$ & $\begin{array}{l}\text { Faixa } 3 \text { do MCMV. Localiza-se na } \\
\text { Região Sul. Construtora: Goldfarb } \\
\text { Incorporações e Construções. }\end{array}$ \\
\hline 127 & $04 / 2013$ & Parque Capital & $\begin{array}{l}\text { Minha Casa Minha } \\
\text { Vida III }\end{array}$ & $\begin{array}{l}240 \\
\text { apartamentos }\end{array}$ & $\begin{array}{l}\text { Faixa } 3 \text { do MCMV. Localiza-se na } \\
\text { Região Sudoeste. Construtora: MRV } \\
\text { Engenharia e Participações. }\end{array}$ \\
\hline 128 & $04 / 2013$ & $\begin{array}{l}\text { Rossi Ideal - } \\
\text { Água Doce }\end{array}$ & $\begin{array}{l}\text { Minha Casa Minha } \\
\text { Vida II }\end{array}$ & $\begin{array}{l}280 \\
\text { apartamentos }\end{array}$ & $\begin{array}{l}\text { Faixa } 2 \text { do MCMV. Construtora: Santa } \\
\text { Clara Tarcila Empreendimentos } \\
\text { Imobiliários Ltda. }\end{array}$ \\
\hline 129 & $05 / 2013$ & $\begin{array}{l}\text { Rossi Ideal - } \\
\text { Águas Claras }\end{array}$ & $\begin{array}{l}\text { Minha Casa Minha } \\
\text { Vida II / III }\end{array}$ & $\begin{array}{l}200 \\
\text { apartamentos }\end{array}$ & $\begin{array}{l}\text { Faixa } 2 \text { ou } 3 \text { do MCMV. Construtora: } \\
\text { Santa Clara Tarcila Empreendimentos } \\
\text { Imobiliários Ltda. }\end{array}$ \\
\hline 130 & $05 / 2013$ & $\begin{array}{l}\text { Rossi Ideal - } \\
\text { Conquista }\end{array}$ & $\begin{array}{l}\text { Minha Casa Minha } \\
\text { Vida III }\end{array}$ & $\begin{array}{l}180 \\
\text { apartamentos }\end{array}$ & $\begin{array}{l}\text { Faixa } 3 \text { do MCMV. Construtora: São } \\
\text { Quirino Empreendimentos Imobiliários } \\
\text { Ltda. }\end{array}$ \\
\hline 131 & $06 / 2013$ & $\begin{array}{l}\text { Rossi Ideal - } \\
\text { Vitória Régia }\end{array}$ & $\begin{array}{l}\text { Minha Casa Minha } \\
\text { Vida II }\end{array}$ & $\begin{array}{l}200 \\
\text { apartamentos }\end{array}$ & $\begin{array}{l}\text { Faixa } 2 \text { do MCMV. Construtora: Santa } \\
\text { Clara Tarcila Empreendimentos } \\
\text { Imobiliários Ltda. }\end{array}$ \\
\hline
\end{tabular}




\begin{tabular}{|c|c|c|c|c|c|}
\hline & \multicolumn{5}{|c|}{ Produção Habitacional de Campinas } \\
\hline & $\begin{array}{l}\text { Ano de } \\
\text { entrega }\end{array}$ & $\begin{array}{l}\text { Nome do } \\
\text { Conjunto }\end{array}$ & $\begin{array}{l}\text { Agente } \\
\text { financeiro } \\
\text { / Parcerias }\end{array}$ & $\begin{array}{c}\text { No de } \\
\text { Unidades } \\
\text { Habitacionais }\end{array}$ & Observações \\
\hline 132 & $07 / 2013$ & $\begin{array}{l}\text { Spazio } \\
\text { Confiance }\end{array}$ & $\begin{array}{l}\text { Minha Casa Minha } \\
\text { Vida II }\end{array}$ & $\begin{array}{l}245 \\
\text { apartamentos }\end{array}$ & $\begin{array}{l}\text { Faixa } 2 \text { do MCMV. Construtora: MRV } \\
\text { Engenharia e Participações S. A. }\end{array}$ \\
\hline 133. & $10 / 2013$ & $\begin{array}{l}\text { Residencial } \\
\text { Caiapó I }\end{array}$ & $\begin{array}{l}\text { Minha Casa Minha } \\
\text { Vida II }\end{array}$ & $\begin{array}{l}160 \\
\text { apartamentos }\end{array}$ & $\begin{array}{l}\text { Faixa } 2 \text { do MCMV. Construtora: } \\
\text { Riwenda Construções e Negócios } \\
\text { Imobiliários Ltda. }\end{array}$ \\
\hline 1341 & $11 / 2013$ & $\begin{array}{l}\text { Residencial } \\
\text { Novo Capivari } \\
\text { Módulo I }{ }^{74}\end{array}$ & $\begin{array}{l}\text { Minha Casa Minha } \\
\text { Vida II }\end{array}$ & $\begin{array}{l}128 \\
\text { apartamentos }\end{array}$ & $\begin{array}{l}\text { Faixa } 2 \text { do MCMV. Construtora: } \\
\text { Caiçaras Empreendimentos } \\
\text { Imobiliários Ltda. }\end{array}$ \\
\hline 135 & 2013 & $\begin{array}{l}\text { Residencial } \\
\text { Quilombo I e } \\
\text { II }\end{array}$ & $\begin{array}{l}\text { PAC (gov. } \\
\text { federal), } \\
\text { Prefeitura de } \\
\text { Campinas e } \\
\text { COHAB }\end{array}$ & 96 casas & $\begin{array}{l}\text { São } 42 \text { sobrados e } 54 \text { unidades } \\
\text { térreas. PAC - Programa de } \\
\text { Arrendamento Residencial do governo } \\
\text { federal. O projeto foi para o } \\
\text { reassentamento de famílias das } \\
\text { favelas de Santa Monica, São Marcos e } \\
\text { Jd. Campineiro. A COHAB Campinas } \\
\text { fez apenas o projeto. }\end{array}$ \\
\hline 136 & 2013 & $\begin{array}{l}\text { Núcleo Res. } \\
\text { Guaraçaí - } \\
\text { PAC FNHIS }\end{array}$ & $\begin{array}{l}\text { PAC (gov. } \\
\text { federal), } \\
\text { Prefeitura de } \\
\text { Campinas e } \\
\text { COHAB Campinas }\end{array}$ & $\begin{array}{l}56 \text { casas } \\
\text { (tipo: sobrados } \\
\text { e térreas) }\end{array}$ & $\begin{array}{l}\text { O Núcleo Residencial Guaraçai - PAC } \\
\text { FNHIS foi executado por meio de } \\
\text { contrato de repasse entre a União } \\
\text { Federal, por intermédio do Ministério } \\
\text { das Cidades, representada pela Caixa } \\
\text { Econômica Federal como instituição } \\
\text { financeira, e a Prefeitura Municipal de } \\
\text { Campinas. O projeto foi elaborado } \\
\text { pela COHAB Campinas. }\end{array}$ \\
\hline $137 C$ & $01 / 2014$ & $\begin{array}{l}\text { Residencial } \\
\text { Flávia /Spazio } \\
\text { Ouro Verde }\end{array}$ & $\begin{array}{l}\text { Programa Minha } \\
\text { Casa Minha Vida } \\
\text { II }\end{array}$ & 137 casas & $\begin{array}{l}\text { Faixa } 2 \text { do MCMV. Construtora: Gold } \\
\text { Cuba Empreendimentos Imobiliários } \\
\text { SPE Ltda. }\end{array}$ \\
\hline 138( & $03 / 2014$ & Turquesa Ville & $\begin{array}{l}\text { Minha Casa Minha } \\
\text { Vida III }\end{array}$ & $\begin{array}{l}448 \\
\text { apartamentos }\end{array}$ & $\begin{array}{l}\text { Faixa } 3 \text { do MCMV. Localiza-se na } \\
\text { Região Sul. Construtora: MRV } \\
\text { Engenharia e Participações. }\end{array}$ \\
\hline 139 & $04 / 2014$ & $\begin{array}{l}\text { Cond. } \\
\text { Residencial } \\
\text { Caiapó II }\end{array}$ & $\begin{array}{l}\text { Minha Casa Minha } \\
\text { Vida II }\end{array}$ & $\begin{array}{l}160 \\
\text { apartamentos }\end{array}$ & $\begin{array}{l}\text { Faixa } 2 \text { do MCMV. Construtora: } \\
\text { Riwenda Construções e Negócios } \\
\text { Imobiliários Ltda. }\end{array}$ \\
\hline 140( & $05 / 2014$ & $\begin{array}{l}\text { Residencial } \\
\text { Vista Prado }\end{array}$ & $\begin{array}{l}\text { Minha Casa Minha } \\
\text { Vida III }\end{array}$ & $\begin{array}{l}188 \\
\text { apartamentos }\end{array}$ & $\begin{array}{l}\text { Faixa } 3 \text { do MCMV. Construtora: Jardim } \\
\text { Nova Eur. }\end{array}$ \\
\hline 141( & $05 / 2014$ & $\begin{array}{l}\text { Residencial } \\
\text { Águas Belas }\end{array}$ & $\begin{array}{l}\text { Minha Casa Minha } \\
\text { Vida II / III } \\
\end{array}$ & $\begin{array}{l}240 \\
\text { apartamentos }\end{array}$ & $\begin{array}{l}\text { Faixas } 2 \text { ou } 3 \text { do MCMV. Construtora: } \\
\text { MRV Engenharia e Participações S. A. }\end{array}$ \\
\hline 142( & $05 / 2014$ & Cosmos I & $\begin{array}{l}\text { Minha Casa Minha } \\
\text { Vida III }\end{array}$ & 24 casas & $\begin{array}{l}\text { Faixa } 3 \text { do MCMV. Cosmos I. } \\
\text { Construtora: Cosmos. }\end{array}$ \\
\hline $143 C$ & $05 / 2014$ & \begin{tabular}{|l} 
Residencial \\
Água Branca
\end{tabular} & $\begin{array}{l}\text { Minha Casa Minha } \\
\text { Vida II / III }\end{array}$ & $\begin{array}{l}240 \\
\text { apartamentos }\end{array}$ & $\begin{array}{l}\text { Faixas } 2 \text { ou } 3 \text { do MCMV. Construtora: } \\
\text { MRV Engenharia e Participações S/A. }\end{array}$ \\
\hline 144( & $05 / 2014$ & $\begin{array}{l}\text { Residencial } \\
\text { Águas Claras } \\
\end{array}$ & $\begin{array}{l}\text { Minha Casa Minha } \\
\text { Vida II / III } \\
\end{array}$ & $\begin{array}{l}240 \\
\text { apartamentos }\end{array}$ & $\begin{array}{l}\text { Faixas } 2 \text { ou } 3 \text { do MCMV. Construtora: } \\
\text { MRV Engenharia e Participações S/A. }\end{array}$ \\
\hline $145 C$ & $05 / 2014$ & $\begin{array}{l}\text { Residencial } \\
\text { Água Doce }\end{array}$ & $\begin{array}{l}\text { Minha Casa Minha } \\
\text { Vida II / III }\end{array}$ & $\begin{array}{l}240 \\
\text { apartamentos }\end{array}$ & $\begin{array}{l}\text { Faixas } 2 \text { ou } 3 \text { do MCMV. Construtora: } \\
\text { MRV Engenharia e Participações S/A. }\end{array}$ \\
\hline 146( & $06 / 2014$ & $\begin{array}{l}\text { Residencial } \\
\text { Águas de } \\
\text { Limeira }\end{array}$ & $\begin{array}{l}\text { Minha Casa Minha } \\
\text { Vida II / III }\end{array}$ & $\begin{array}{l}240 \\
\text { apartamentos }\end{array}$ & $\begin{array}{l}\text { Faixas } 2 \text { ou } 3 \text { do MCMV. Construtora: } \\
\text { MRV Engenharia e Participações S/A. }\end{array}$ \\
\hline
\end{tabular}

74 Em abril de 2015, foram entregues mais 64 apartamentos (2 blocos) pelo Minha Casa Minha Vida faixa 2, Condomínio Residencial Novo Capivari II, entretanto, essas unidades não constam aqui devido ao ano de entrega. 


\begin{tabular}{|c|c|c|c|c|c|}
\hline \multicolumn{6}{|c|}{ Produção Habitacional de Campinas } \\
\hline & $\begin{array}{l}\text { Ano de } \\
\text { entrega }\end{array}$ & $\begin{array}{l}\text { Nome do } \\
\text { Conjunto }\end{array}$ & $\begin{array}{l}\text { Agente } \\
\text { financeiro } \\
\text { / Parcerias }\end{array}$ & $\begin{array}{c}\text { No de } \\
\text { Unidades } \\
\text { Habitacionais }\end{array}$ & Observações \\
\hline 147 & $06 / 2014$ & \begin{tabular}{|l} 
Residencial \\
Novo Mundo 1 \\
\end{tabular} & $\begin{array}{l}\text { Minha Casa Minha } \\
\text { Vida II / III }\end{array}$ & 61 casas & $\begin{array}{l}\text { Faixas } 2 \text { ou } 3 \text { do MCMV. Construtora: } \\
\text { FUP Engenharia e Construções Ltda. }\end{array}$ \\
\hline 148 & $06 / 2014$ & $\begin{array}{l}\text { Condomínio } \\
\text { Residencial } \\
\text { Caiapó III }\end{array}$ & $\begin{array}{l}\text { Minha Casa Minha } \\
\text { Vida II / III }\end{array}$ & $\begin{array}{l}160 \\
\text { apartamentos }\end{array}$ & $\begin{array}{l}\text { Faixa } 2 \text { ou } 3 \text { do MCMV. Construtora: } \\
\text { Riwenda Construções e Negócios } \\
\text { Imobiliários Ltda. }\end{array}$ \\
\hline 149 & $06 / 2014$ & $\begin{array}{l}\text { Residencial } \\
\text { Vega - } \\
\text { Condomínio } \\
\text { Polaris }\end{array}$ & $\begin{array}{l}\text { Programa Minha } \\
\text { Casa Minha Vida } \\
\text { II }\end{array}$ & $\begin{array}{l}160 \\
\text { apartamentos }\end{array}$ & $\begin{array}{l}\text { Faixa } 2 \text { do MCMV. Construtora: } \\
\text { Cosmos Empreendimentos Imobiliários } \\
\text { Ltda. }\end{array}$ \\
\hline 150 & $08 / 2014$ & $\begin{array}{l}\text { Novo } \\
\text { Horizonte IV }\end{array}$ & $\begin{array}{l}\text { Minha Casa Minha } \\
\text { Vida II / III }\end{array}$ & 30 casas & $\begin{array}{l}\text { Faixa } 2 \text { ou 3. Localiza-se na região Sul. } \\
\text { Construtora: Goldfarb Incorporações e } \\
\text { Construções. }\end{array}$ \\
\hline 151 & $08 / 2014$ & Casas & $\begin{array}{l}\text { Minha Casa Minha } \\
\text { Vida II / III }\end{array}$ & 6 casas & $\begin{array}{l}\text { NÃO MAPEADO (poucas unidades). } \\
\text { Faixas } 2 \text { ou } 3 \text { do MCMV. Construtora: } \\
\text { Somos Construtores Ltda. ME. }\end{array}$ \\
\hline 152 & $09 / 2014$ & $\begin{array}{l}\text { Residencial } \\
\text { Águas da } \\
\text { Serra }\end{array}$ & $\begin{array}{l}\text { Minha Casa Minha } \\
\text { Vida II / III }\end{array}$ & $\begin{array}{l}240 \\
\text { apartamentos }\end{array}$ & $\begin{array}{l}\text { Faixas } 2 \text { ou } 3 \text { do MCMV. Construtora: } \\
\text { MRV Engenharia e Participações S. A. }\end{array}$ \\
\hline 153 & $10 / 2014$ & $\begin{array}{l}\text { Condomínio } \\
\text { Águas de } \\
\text { Lindóia }\end{array}$ & $\begin{array}{l}\text { Minha Casa Minha } \\
\text { Vida II / III }\end{array}$ & $\begin{array}{l}230 \\
\text { apartamentos }\end{array}$ & $\begin{array}{l}\text { Faixa } 2 \text { ou } 3 \text { do MCMV. Construtora: } \\
\text { MRV Engenharia e Participações S/A. }\end{array}$ \\
\hline 154 & $10 / 2014$ & $\begin{array}{l}\text { Condomínio } \\
\text { Residencial } \\
\text { São Bernardo } \\
\text { Gleba } 10 A \\
\end{array}$ & $\begin{array}{l}\text { Minha Casa Minha } \\
\text { Vida II / III }\end{array}$ & $\begin{array}{l}246 \\
\text { apartamentos }\end{array}$ & $\begin{array}{l}\text { Faixas } 2 \text { ou } 3 \text { do MCMV. Construtora: } \\
\text { Campinas Empreendimentos } \\
\text { Imobiliários SPE Ltda. Nome do } \\
\text { Condomínio: Alameda dos Jacarandás. }\end{array}$ \\
\hline 155 & $11 / 2014$ & $\begin{array}{l}\text { Residencial } \\
\text { Takanos I, II e } \\
\text { III }\end{array}$ & $\begin{array}{l}\text { Minha Casa Minha } \\
\text { Vida I e Casa } \\
\text { Paulista }\end{array}$ & $\begin{array}{l}600 \\
\text { apartamentos }\end{array}$ & $\begin{array}{l}\text { Faixa } 1 \text { do MCMV. Localiza-se na } \\
\text { Região Norte. Construtora FYP } \\
\text { Engenharia. }\end{array}$ \\
\hline 156 & \begin{tabular}{|l|}
$6 / 2014-$ \\
$4 / 2015$ \\
\end{tabular} & $\begin{array}{l}\text { Residencial } \\
\text { Vila Abaeté }\end{array}$ & $\begin{array}{l}\text { Minha Casa Minha } \\
\text { Vida I }\end{array}$ & $\begin{array}{l}1.888 \\
\text { apartamentos }\end{array}$ & $\begin{array}{l}\text { Faixa } 1 \text { do MCMV. Localiza-se na } \\
\text { Região Sul. Construtora: Brookfield. }\end{array}$ \\
\hline 157 & $05 / 2012$ & $\begin{array}{l}\text { Parque } \\
\text { Eldorado Fase } \\
\text { III }\end{array}$ & $\begin{array}{l}\text { Minha Casa Minha } \\
\text { Vida II }\end{array}$ & 94 casas & $\begin{array}{l}\text { Faixa } 2 \text { do MCMV. Funchal } \\
\text { Construções Ltda. }\end{array}$ \\
\hline & $\begin{array}{l}\text { tal de Un } \\
\text { oduzidas }\end{array}$ & idades Habita & acionais & 59.681 & \\
\hline & tal de cas & as produzidas & & 22.046 & \\
\hline & al de lote & urbanizados & & 8.181 & \\
\hline & tal de apa & rtamentos prod & uzidos & 29.454 & \\
\hline
\end{tabular}


Tabela 9 - Dados das Habitações de Interesse Social produzidas em Cosmópolis (1964-2014)

\begin{tabular}{|c|c|c|c|c|}
\hline \multicolumn{5}{|c|}{ Produção Habitacional de Cosmópolis ${ }^{75}$} \\
\hline $\begin{array}{l}\text { Ano de } \\
\text { entrega }\end{array}$ & $\begin{array}{l}\text { Nome do } \\
\text { Conjunto }\end{array}$ & $\begin{array}{c}\text { Agente } \\
\text { financeiro } \\
\text { / Parcerias }\end{array}$ & $\begin{array}{c}\mathrm{N}^{\circ} \mathrm{de} \\
\text { Unidades } \\
\text { Habitacionais }\end{array}$ & Observações \\
\hline $0107 / 10 / 1970$ & Vila Nova & $\begin{array}{l}\text { COHAB } \\
\text { Bandeirantes }\end{array}$ & 215 casas & $\begin{array}{l}\text { Localiza-se em uma área de } \\
65.500,25 \mathrm{~m}^{2}, \text { com lotes de } 10 \mathrm{~m} \text { x } 20 \mathrm{~m} \text { e } \\
13,33 \mathrm{~m} \times 15,00 \mathrm{~m} \text {, com casas de } 1 \text { e } 2 \\
\text { dormitórios, medindo } 38 \mathrm{~m}^{2}, 46 \mathrm{~m}^{2} \text { e } 49 \\
\mathrm{~m}^{2} \text {. Lei de base } \mathrm{n}^{\circ} 3.079 \text { de } 15 / 09 / 1938 \text {. }\end{array}$ \\
\hline $0216 / 01 / 1976$ & $\begin{array}{l}\text { Núcleo Res. } \\
\text { Vila } \\
\text { Cosmopolita }\end{array}$ & $\begin{array}{l}\mathrm{COHAB} \\
\text { Bandeirantes }\end{array}$ & 250 casas & $\begin{array}{l}\text { Localiza-se em uma área de } \\
83.246,10 \mathrm{~m}^{2} \text {, com lotes medindo } 15 \mathrm{~m} x \\
13,33 \mathrm{~m} \text {, com casas de } 3 \text { e } 4 \text { dormitórios, } \\
\text { medindo entre } 49 \mathrm{~m}^{2}, 42 \mathrm{~m}^{2} \text { e } 56,62 \mathrm{~m}^{2} \text {. } \\
\text { Lei de Base } \mathrm{n}^{0} 3.079 \text { de } 15 / 09 / 1938 \text {. }\end{array}$ \\
\hline $0329 / 01 / 1982$ & $\begin{array}{l}\text { Conj, Hab. } \\
\text { Vila Cosmos }\end{array}$ & $\begin{array}{l}\text { COHAB } \\
\text { Campinas }\end{array}$ & 308 casas & $\begin{array}{l}\text { Localiza-se em uma área de } \\
133.100,00 \mathrm{~m}^{2}, \text { com lotes medindo } \\
10,00 \mathrm{~m} \times 20,00 \mathrm{~m} \text {, com casas de } 1 \text { e } 2 \\
\text { dormitórios, medindo } 33,99 \mathrm{~m}^{2}, 43,91 \mathrm{~m}^{2}, \\
40,20 \mathrm{~m}^{2}, 38,05 \mathrm{~m}^{2} \text { e } 30,05 \mathrm{~m}^{2} \text {. Lei de } \\
\text { base } \mathrm{n}^{0} 3.079 \text { de } 15 / 09 / 1938 .\end{array}$ \\
\hline $04 \quad 14 / 09 / 1982$ & $\begin{array}{l}\text { Conjunto } \\
\text { Hab. } 30 \text { de } \\
\text { Novembro }\end{array}$ & $\mathrm{COHAB}$ & 214 casas & $\begin{array}{l}\text { Localiza-se em uma área de } 72.600,00 \\
\mathrm{~m}^{2} \text {, lotes medindo aproximadamente } 10 \mathrm{~m} \\
\mathrm{x} 20 \mathrm{~m} \text {, com casas de } 1 \text { e } 2 \text { dormitórios, } \\
\text { medindo entre } 34 \text { e } 44 \mathrm{~m}^{2} \text {. O projeto } \\
\text { visou atender famílias com renda entre } 1 \\
\text { e } 5 \text { SM. Lei: } \mathrm{n}^{0} 940 \text { de } 15 / 12 / 1976 \text {. }\end{array}$ \\
\hline 05 26/03/1989 & $\begin{array}{l}\text { Parque } \\
\text { Independên- } \\
\text { cia }\end{array}$ & \begin{tabular}{|l} 
Prefeitura \\
Municipal de \\
Cosmópolis
\end{tabular} & 128 lotes & $\begin{array}{l}\text { Lotes doados pela prefeitura }\left(140 \mathrm{~m}^{2} \text { e }\right. \\
\left.296 \mathrm{~m}^{2}\right) \text {, com doação de plantas } \\
\left(46,00 \mathrm{~m}^{2} \text { a } 69,00 \mathrm{~m}^{2}\right) \text { e acompanhamento } \\
\text { técnico e Social. Lei de Criação: } \mathrm{n}^{\circ} 1.561 \\
(12 / 06 / 1989) \text {. }\end{array}$ \\
\hline $0610 / 10 / 1989$ & $\begin{array}{l}\text { Jd. Chico } \\
\text { Mendes }\end{array}$ & \begin{tabular}{|l} 
Prefeitura \\
Municipal de \\
Cosmópolis
\end{tabular} & 300 lotes & $\begin{array}{l}\text { Lotes doados }\left(140 \mathrm{~m}^{2} \text { e } 296 \mathrm{~m}^{2}\right), \text { com } \\
\text { doação de plantas medindo } 46,00 \mathrm{~m}^{2} \text { a } \\
69,00 \mathrm{~m}^{2} \text {. Acompanhamento Técnico e } \\
\text { Social. Lei de Criação: No } 1.599 \text { de } \\
1 / 10 / 1989 \text {. }\end{array}$ \\
\hline $0726 / 03 / 1991$ & Jd. Santana & $\begin{array}{l}\text { Prefeitura } \\
\text { Municipal de } \\
\text { Cosmópolis }\end{array}$ & 8 lotes & $\begin{array}{l}\text { NÃO MAPEADO (devido ao método } \\
\text { adotado, são mapeados apenas conjuntos } \\
\text { com mais de } 10 \text { UH). Lotes doados } \\
\left(140 m^{2} \text { e } 296 m^{2}\right) \text {, com doação de plantas } \\
\text { medindo } 46,00 m^{2} \text { a } 69,00 m^{2} \text {. } \\
\text { Acompanhamento Técnico e Social. Lei } \\
\text { de Criação: No } 1.740 \text {, de 15/03/1991. }\end{array}$ \\
\hline $0810 / 04 / 1991$ & $\begin{array}{l}\text { Pq. Dona } \\
\text { Esther }\end{array}$ & $\begin{array}{l}\text { Prefeitura } \\
\text { Municipal de } \\
\text { Cosmópolis }\end{array}$ & 28 lotes & $\begin{array}{l}\text { Lotes doados }\left(140 \mathrm{~m}^{2} \text { e } 296 \mathrm{~m}^{2}\right), \text { com } \\
\text { doação de plantas medindo } 46,00 \mathrm{~m}^{2} \text { a } \\
69,00 \mathrm{~m}^{2} \text {. Acompanhamento Técnico e } \\
\text { Social. Lei de Criação no } 1.742 \text { de } \\
10 / 04 / 1991 \text {. }\end{array}$ \\
\hline
\end{tabular}

75 Quando houve o levantamento de dados em Cosmópolis, tomou-se conhecimento do empreendimento de HIS Residencial Cosmópolis II, também denominado Residencial Monte Castelo I, com 300 apartamentos. No entanto, o mesmo não consta das tabelas por estar fora do recorte temporal do trabalho, pois a previsão de entrega é em agosto de 2016. 


\begin{tabular}{|c|c|c|c|c|}
\hline \multicolumn{5}{|c|}{ Produção Habitacional de Cosmópolis ${ }^{75}$} \\
\hline $\begin{array}{l}\text { Ano de } \\
\text { entrega }\end{array}$ & $\begin{array}{l}\text { Nome do } \\
\text { Conjunto }\end{array}$ & $\begin{array}{c}\text { Agente } \\
\text { financeiro } \\
\text { / Parcerias }\end{array}$ & $\begin{array}{c}\mathrm{N}^{\circ} \mathrm{de} \\
\text { Unidades } \\
\text { Habitacionais }\end{array}$ & Observações \\
\hline $0910 / 04 / 1991$ & $\begin{array}{l}\text { Jardim das } \\
\text { Paineiras }\end{array}$ & \begin{tabular}{|l} 
Prefeitura \\
Municipal de \\
Cosmópolis
\end{tabular} & 193 lotes & $\begin{array}{l}\text { Lotes doados }\left(140 \mathrm{~m}^{2} \text { e } 296 \mathrm{~m}^{2}\right), \text { com } \\
\text { doação de plantas medindo } 46,00 \mathrm{~m}^{2} \text { a } \\
69,00 \mathrm{~m}^{2} \text {, acompanhamento técnico e } \\
\text { social. Lei de criação no } 1.743 \text { de } \\
\text { 10/04/1991. }\end{array}$ \\
\hline $1014 / 12 / 1992$ & $\begin{array}{l}\text { Parque dos } \\
\text { Trabalhado- } \\
\text { res }\end{array}$ & \begin{tabular}{|l} 
Prefeitura \\
Municipal de \\
Cosmópolis
\end{tabular} & 186 lotes & $\begin{array}{l}\text { Lotes doados }\left(140 \mathrm{~m}^{2} \text { e } 296 \mathrm{~m}^{2}\right) \text {, com } \\
\text { doação de plantas medindo } 46,00 \mathrm{~m}^{2} \text { a } \\
69,00 \mathrm{~m}^{2} \text {, acompanhamento técnico e } \\
\text { social. Lei de criação no } 1.921 \text { de } \\
\text { 14/12/1992. }\end{array}$ \\
\hline $1107 / 11 / 1994$ & $\begin{array}{l}\text { Jd. Beto } \\
\text { Spana }\end{array}$ & $\begin{array}{l}\text { Prefeitura } \\
\text { Municipal de } \\
\text { Cosmópolis }\end{array}$ & 382 lotes & $\begin{array}{l}\text { Lotes doados }\left(140 \mathrm{~m}^{2} \text { e } 296 \mathrm{~m}^{2}\right) \text {, com } \\
\text { doação de plantas medindo de } 46,00 \mathrm{~m}^{2} \text { a } \\
69,00 \mathrm{~m}^{2} \text {, houve acompanhamento } \\
\text { técnico e social. Lei de criação nº } 2.072 \\
\text { de } 07 / 11 / 1994 \text {. }\end{array}$ \\
\hline $1210 / 04 / 2003$ & $\begin{array}{l}\text { Residencial } \\
1^{0} \text { de Maio }\end{array}$ & $\begin{array}{l}\text { PAR (Caixa } \\
\text { Econômica } \\
\text { Federal) e } \\
\text { Prefeitura de } \\
\text { Cosmópolis }\end{array}$ & 274 casas $^{76}$ & $\begin{array}{l}\text { Financiado com Recursos do PAR } \\
\text { (Programa de Arrendamento Residencial), } \\
\text { um convênio firmado com a Caixa } \\
\text { Econômica Federal. Apresenta lotes de } \\
11,00 \mathrm{~m} \text { x } 20,00 \mathrm{~m} \text { (casas de } 1 \text { e } 2 \\
\text { dormitórios, medindo entre } 33,99 \mathrm{~m}^{2} \text { e } \\
\left.43,91 \mathrm{~m}^{2}\right) \text {. }\end{array}$ \\
\hline $1310 / 05 / 2007$ & $\begin{array}{l}\text { Residencial } \\
\text { Cosmópolis I }\end{array}$ & $\begin{array}{l}\text { Minha Casa } \\
\text { Minha Vida II }\end{array}$ & 230 casas & $\begin{array}{l}\text { Faixa } 2 \text { do MCMV. Financiado com os } \\
\text { recursos do PAR (Programa de } \\
\text { Arrendamento Residencial), um convênio } \\
\text { firmado com a Caixa Econômica Federal, } \\
\text { em parceria com a prefeitura municipal } \\
\text { Empreendimento com lotes medindo } \\
11,00 m \text { x } 20,00 \mathrm{~m} \text {, com casas de } 1 \text { e } 2 \\
\text { dormitórios, medindo entre } 33,99 \mathrm{~m}^{2} \text { e } \\
43,91 \mathrm{~m}^{2} \text {. }\end{array}$ \\
\hline 2012 & $\begin{array}{l}\text { Residencial } \\
\text { Manoel } \\
\text { Ferreira de } \\
\text { Souza }\end{array}$ & $\begin{array}{l}\text { MCMV } 1 \text { e } \\
\text { Prefeitura } \\
\text { Municipal }\end{array}$ & $\begin{array}{l}688 \\
\text { apartamentos }\end{array}$ & $\begin{array}{l}\text { Faixa } 1 \text { do MCMV. Apartamentos verticais, } \\
\text { medindo entre } 46 \mathrm{~m}^{2} \text { e } 47 \mathrm{~m}^{2} . \text { A } \\
\text { Prefeitura de Cosmópolis realizou: } \\
\text { cadastramento, triagem, acerto de } \\
\text { demanda (sorteios) e acompanhamento } \\
\text { técnico e social. }\end{array}$ \\
\hline $\begin{array}{l}\text { Total de Unic } \\
\text { produzidas }\end{array}$ & dades Habita & acionais & 3.404 & \\
\hline Total de casas & produzidas & & 1.491 & \\
\hline Total de lotes & urbanizados p & roduzidos & 1.225 & \\
\hline Total de apart & amentos produ & uzidos & 688 & \\
\hline
\end{tabular}

${ }^{76} \mathrm{O}$ projeto inicial contava com 200 casas, entretanto, houve uma ampliação e passou a contar com 274 casas, conforme informação enviada pela Diretoria de Habitação por e-mail (05/08/2015). 
Tabela 10 - Dados das Habitações de Interesse Social produzidas em Engenheiro Coelho (1964-2014)

\begin{tabular}{|c|c|c|c|c|c|}
\hline \multicolumn{6}{|c|}{ Produção Habitacional de Engenheiro Coelho } \\
\hline & $\begin{array}{l}\text { Ano de } \\
\text { entrega }\end{array}$ & $\begin{array}{l}\text { Nome do } \\
\text { Conjunto }\end{array}$ & $\begin{array}{c}\text { Agente financeiro } \\
\text { / Parcerias }\end{array}$ & $\begin{array}{l}\text { No de Unidades } \\
\text { Habitacionais }\end{array}$ & Observações \\
\hline 01 & 2004 & $\begin{array}{l}\text { Residencial } \\
\text { Eldorado I }\end{array}$ & Prefeitura Municipal & 165 lotes & $\begin{array}{l}\text { Lotes foram doados aos } \\
\text { munícipes pela prefeitura, } \\
\text { assim como as plantas. A } \\
\text { regulamentação ocorreu } \\
\text { por meio do Decreto } \\
\text { Municipal no } 244 / 2003 \text {. }\end{array}$ \\
\hline 02 & 2014 & $\begin{array}{l}\text { Residencial } \\
\text { Sonho Meu }\end{array}$ & $\begin{array}{l}\text { Minha Casa Minha } \\
\text { Vida I }\end{array}$ & 300 apartamentos & Faixa 1 do MCMV. \\
\hline \multicolumn{4}{|c|}{ Total de Unidades Habitacionais produzidas } & 465 & \\
\hline \multicolumn{4}{|c|}{ Total de casas produzidas } & 0 & \\
\hline \multicolumn{4}{|c|}{ Total de lotes urbanizados produzidos } & 165 & \\
\hline \multicolumn{4}{|c|}{ Total de apartamentos produzidos } & 300 & \\
\hline
\end{tabular}

Tabela 11 - Dados das Habitações de Interesse Social produzidas em Holambra (1964-2014)

\begin{tabular}{|c|c|c|c|c|}
\hline \multicolumn{5}{|c|}{ Produção Habitacional de Holambra } \\
\hline $\begin{array}{l}\text { Ano de } \\
\text { entrega }\end{array}$ & $\begin{array}{l}\text { Nome do } \\
\text { Conjunto }\end{array}$ & $\begin{array}{l}\text { Agente } \\
\text { Financeiro }\end{array}$ & $\begin{array}{l}\text { No de Unidades } \\
\text { Habitacionais }\end{array}$ & Observações \\
\hline 1995 & Flamboyant & $\begin{array}{l}\text { Prefeitura } \\
\text { Municipal de } \\
\text { Holambra }\end{array}$ & 147 lotes & $\begin{array}{l}\text { A prefeitura realizou a doação de lotes } \\
\text { de } 250 \mathrm{~m}^{2} \text { a } 500 \mathrm{~m}^{2} \text {, cuja } \\
\text { regulamentação ocorreu por meio da Lei } \\
\text { municipal no } 3119 / 95 \text {. A prefeitura } \\
\text { também doou plantas de } 42 \mathrm{~m}^{2}, 60 \mathrm{~m}^{2} \text { ou } \\
70 \mathrm{~m}^{2} \text {. }\end{array}$ \\
\hline 1996 & Ype & $\begin{array}{l}\text { Prefeitura } \\
\text { Municipal de } \\
\text { Holambra }\end{array}$ & 215 lotes & $\begin{array}{l}\text { A prefeitura realizou a doação de lotes } \\
\text { (cerca de } 200 \mathrm{~m}^{2} \text { ), cuja regulamentação } \\
\text { ocorreu por meio da Lei municipal } \mathrm{n}^{0} \\
63 / 1996 \text {. A prefeitura doou plantas de } \\
42 \mathrm{~m}^{2}, 60 \mathrm{~m}^{2} \text { ou } 70 \mathrm{~m}^{2} \text {. }\end{array}$ \\
\hline \multicolumn{3}{|c|}{$\begin{array}{l}\text { Total de Unidades Habitacionais } \\
\text { produzidas }\end{array}$} & \multicolumn{2}{|c|}{362 lotes } \\
\hline \multicolumn{3}{|c|}{ Total de casas produzidas } & \multicolumn{2}{|c|}{0} \\
\hline \multicolumn{3}{|c|}{ Total de lotes urbanizados produzidos } & \multicolumn{2}{|l|}{362} \\
\hline \multicolumn{3}{|c|}{ Total de apartamentos produzidos } & \multicolumn{2}{|l|}{0} \\
\hline
\end{tabular}


Tabela 12 - Dados das Habitações de Interesse Social produzidas em Hortolândia ${ }^{77}$ (19642014)

\begin{tabular}{|c|c|c|c|c|c|}
\hline \multicolumn{6}{|c|}{ Produção Habitacional ${ }^{78}$ de Hortolândia } \\
\hline & $\begin{array}{c}\text { Ano de } \\
\text { entrega }\end{array}$ & $\begin{array}{l}\text { Nome do } \\
\text { Conjunto }\end{array}$ & $\begin{array}{c}\text { Agente financeiro } \\
\text { / Parcerias }\end{array}$ & $\begin{array}{c}\text { No de Unidades } \\
\text { Habitacionais }\end{array}$ & Observações \\
\hline 01 & 2010 & Vila São Pedro & $\mathrm{CDHU}$ & 320 apartamentos & \\
\hline 02 & 2011 & $\begin{array}{l}\text { Jardim } \\
\text { Primavera } \\
\text { (casas) }\end{array}$ & $\begin{array}{l}\text { PAC /OGU e } \\
\text { Prefeitura Municipal } \\
\text { de Hortolândia }\end{array}$ & 499 casas & Localizado em ZEIS. \\
\hline 03 & 2012 & $\begin{array}{l}\text { Condomínio } \\
\text { Praia Grande }\end{array}$ & $\begin{array}{l}\text { Programa Minha } \\
\text { Casa Minha Vida I }\end{array}$ & 260 apartamentos & $\begin{array}{l}\text { Faixa } 1 \text { do MCMV. Localiza-se no } \\
\text { Jd Minda. } \\
\text { Construtora e Incorp. Faleiros } \\
\text { LTDA. }\end{array}$ \\
\hline 04 & 2012 & $\begin{array}{l}\text { Condomínio } \\
\text { Peruíbe }\end{array}$ & $\begin{array}{l}\text { Programa Minha } \\
\text { Casa Minha Vida I }\end{array}$ & 240 apartamentos & $\begin{array}{l}\text { Faixa } 1 \text { do MCMV. Localiza-se no } \\
\text { Jd Minda. Construtora: Multipla } \\
\text { Engenharia LTDA. }\end{array}$ \\
\hline 05 & 2013 & $\begin{array}{l}\text { Condomínio } \\
\text { Bertioga }\end{array}$ & $\begin{array}{l}\text { Programa Minha } \\
\text { Casa Minha Vida I }\end{array}$ & 300 apartamentos & $\begin{array}{l}\text { Faixa } 1 \text { do MCMV. Localiza-se no } \\
\text { Jd. Novo Ângulo. Os prédios }\end{array}$ \\
\hline 06 & 2013 & $\begin{array}{l}\text { Condomínio } \\
\text { Guarujá }\end{array}$ & $\begin{array}{l}\text { Programa Minha } \\
\text { Casa Minha Vida I }\end{array}$ & 300 apartamentos & $\begin{array}{l}\text { apresentam térreo }+4 \\
\text { pavimentos. }\end{array}$ \\
\hline 07 & 2014 & $\begin{array}{l}\text { Condomínio } \\
\text { Portugal }\end{array}$ & Programa Minha & 240 apartamentos & Faixa 1 do MCMV. Localiza-se em \\
\hline 08 & 2014 & $\begin{array}{l}\text { Condomínio } \\
\text { Espanha }\end{array}$ & Casa Minha Vida I e & 260 apartamentos & $\begin{array}{l}\text { ZEIS. } \\
\text { Construtora: Itajaí Ltda. }\end{array}$ \\
\hline 09 & 2014 & $\begin{array}{l}\text { Condomínio } \\
\text { Suíça }\end{array}$ & governo do Estado) & 240 apartamentos & \\
\hline 10 & 2014 & Bromélias I & & 200 apartamentos & Faixa 1 do MCMV. Conforme \\
\hline 11 & 2014 & Bromélias II & $\begin{array}{l}\text { Programa Minha } \\
\text { Casa Minha Vida I e } \\
\text { Governo do Estado } \\
\text { de São Paulo } \\
\text { (Fundo Paulista de } \\
\text { HIS) }\end{array}$ & 240 apartamentos & $\begin{array}{l}\text { informação da Secretaria de } \\
\text { Habitação do Município, a } \\
\text { instituição financeira é a Caixa e } \\
\text { houve aporte do Governo do } \\
\text { Estado de São Paulo - Fundo } \\
\text { Paulista de Habitação de } \\
\text { Interesse Social. }\end{array}$ \\
\hline 12 & $01 / 2010$ & $\begin{array}{l}\text { Cond. Res. } \\
\text { Horizontal } \\
\text { Hortoville }\end{array}$ & $\begin{array}{l}\text { Programa Minha } \\
\text { Casa Minha Vida II } \\
\text { / III }\end{array}$ & 12 casas & $\begin{array}{l}\text { Faixa } 2 \text { ou } 3 \text { do MCMV. } \\
\text { Construtora: Hortoville } \\
\text { Incorporação Imobiliária Ltda. }\end{array}$ \\
\hline 13 & $05 / 2011$ & $\begin{array}{l}\text { Vila Flora - } \\
\text { condomínio } 1\end{array}$ & $\begin{array}{l}\text { Minha Casa Minha } \\
\text { Vida III }\end{array}$ & 180 casas & $\begin{array}{l}\text { Faixa } 3 \text { do MCMV. Construtora: } \\
\text { Vila Flora Hortolândia } \\
\text { Empreendimentos Imobiliários } \\
\text { Ltda. }\end{array}$ \\
\hline 14 & 09/2011 & $\begin{array}{l}\text { Alameda das } \\
\text { Flores }\end{array}$ & $\begin{array}{l}\text { Minha Casa Minha } \\
\text { Vida III }\end{array}$ & 64 apartamentos & $\begin{array}{l}\text { Faixa } 3 \text { do MCMV. Construtora: } \\
\text { Barretto e Santos construtora e } \\
\text { incorporadora LTDA. }\end{array}$ \\
\hline
\end{tabular}

\footnotetext{
77 Esta pesquisa trata das Habitações de Interesse Social produzidas entre 1964 e 2014. No entanto, ao realizar o levantamento em Hortolândia, tomou-se conhecimento de outros empreendimentos com previsão de entrega em 2015 e 2016: Condomínio França (220 UH), Cond. Itália (220 UH), Cond. Novo Estrela (672 UH), Condomínio Bromélias I e II (440 UH) e Jd. Boa Esperança (100 UH).

${ }^{78}$ Conforme informação fornecida pela Secretaria de Habitação (por meio de processo aberto para solicitação dos dados da produção de HIS no município), os empreendimentos habitacionais MCMV (faixa 1) e CDHU são destinados a famílias com renda entre 0 e 3 salários mínimos e são regulamentados pela Lei Municipal de Interesse Social: 2.298/2009 e alterações 2.640/2011 e 2.848/2013.

${ }^{79}$ A informação sobre a data de entrega dos conjuntos Certto Tons da Noite (2013) e Parque Harvard (2014) foi obtida por meio de entrevista (realizada em 16/01/2015) com moradores que ocupam o empreendimento desde o início, visto que não foi possível obter essa informação diretamente no agente financeiro ou na prefeitura.
} 


\begin{tabular}{|c|c|c|c|c|c|}
\hline \multicolumn{6}{|c|}{ Produção Habitacional ${ }^{78}$ de Hortolândia } \\
\hline & $\begin{array}{l}\text { Ano de } \\
\text { entrega }^{79}\end{array}$ & $\begin{array}{l}\text { Nome do } \\
\text { Conjunto }\end{array}$ & $\begin{array}{c}\text { Agente financeiro } \\
\text { / Parcerias }\end{array}$ & $\begin{array}{l}\text { No de Unidades } \\
\text { Habitacionais }\end{array}$ & Observações \\
\hline 15 & $01 / 2012$ & $\begin{array}{l}\text { Vila Flora - } \\
\text { condomínio } 3 \\
\text { (fase 2) }\end{array}$ & $\begin{array}{l}\text { Minha Casa Minha } \\
\text { Vida III }\end{array}$ & $\begin{array}{l}80 \text { casas e } 48 \\
\text { apartamentos }\end{array}$ & $\begin{array}{l}\text { Faixa } 3 \text { do MCMV. Construtora: } \\
\text { Vila Flora Hortolândia } \\
\text { Empreendimentos Imobiliários } \\
\text { Ltda. }\end{array}$ \\
\hline 16 & $01 / 2012$ & $\begin{array}{l}\text { Vila Flora - } \\
\text { condomínio } 2\end{array}$ & $\begin{array}{l}\text { Minha Casa Minha } \\
\text { Vida III }\end{array}$ & $\begin{array}{l}46 \text { casas e } 72 \\
\text { apartamentos }\end{array}$ & $\begin{array}{l}\text { Faixa } 3 \text { do MCMV. Construtora: } \\
\text { Vila Flora Hortolândia } \\
\text { Empreendimentos Imobiliários } \\
\text { Ltda. }\end{array}$ \\
\hline 17 & $01 / 2012$ & $\begin{array}{l}\text { Vila Flora - } \\
\text { condomínio } 3 \\
\text { (fase 1) }\end{array}$ & $\begin{array}{l}\text { Minha Casa Minha } \\
\text { Vida III }\end{array}$ & $\begin{array}{l}66 \text { casas e } 12 \\
\text { apartamentos }\end{array}$ & $\begin{array}{l}\text { Faixa } 3 \text { do MCMV. Construtora: } \\
\text { Vila Flora Hortolândia } \\
\text { Empreendimentos Imobiliários } \\
\text { Ltda. }\end{array}$ \\
\hline 18 & $\begin{array}{c}03 / 2012 a \\
05 / 2012\end{array}$ & $\begin{array}{l}\text { Condomínio } \\
\text { Hortolândia }\end{array}$ & $\begin{array}{l}\text { Minha Casa Minha } \\
\text { Vida III }\end{array}$ & 532 apartamentos & $\begin{array}{l}\text { Faixa } 3 \text { do MCMV. Construtoras: } \\
\text { Eustoma Empreendimentos S/A, } \\
\text { São Marcal Empreendimentos } \\
\text { Imobiliários Ltda. e São Mario } \\
\text { Empreendimentos Imobiliários } \\
\text { Ltda. O condomínio Hortolândia } \\
\text { contempla o Avalon Praças } \\
\text { Residenciais, o Rossi Ideal I } \\
\text { (Laranjeiras) e Rossi Ideal II } \\
\text { (Pitangueiras). }\end{array}$ \\
\hline 19 & 2013 & $\begin{array}{l}\text { Certto Tons da } \\
\text { Noite }\end{array}$ & $\begin{array}{l}\text { Minha Casa Minha } \\
\text { Vida III - Banco do } \\
\text { Brasil }\end{array}$ & 160 apartamentos & $\begin{array}{l}\text { Faixa } 3 \text { do MCMV. Construtora: } \\
\text { Plano Macieira Empreendimentos } \\
\text { Imobiliários LTDA. }\end{array}$ \\
\hline 20 & $05 / 2013$ & $\begin{array}{l}\text { Condomínio } \\
\text { Hortolândia } \\
\text { Doce Lar }\end{array}$ & $\begin{array}{l}\text { Minha Casa Minha } \\
\text { Vida III }\end{array}$ & 191 apartamentos & $\begin{array}{l}\text { Faixa } 3 \text { do MCMV. Construtora: } \\
\text { Brookfield Empreendimentos } \\
\text { Economicos S.A. }\end{array}$ \\
\hline 21 & $11 / 2013$ & $\begin{array}{l}\text { Cond. Res. } \\
\text { Hortolândia II - } \\
\text { Orquídeas }\end{array}$ & $\begin{array}{l}\text { Minha Casa Minha } \\
\text { Vida III }\end{array}$ & 173 casas & $\begin{array}{l}\text { Faixa } 3 \text { do MCMV. Construtora: } \\
\text { Hortolândia 4A Empreendimento } \\
\text { Imobiliário SPE LTDA. }\end{array}$ \\
\hline 22 & $11 / 2013$ & $\begin{array}{l}\text { Cond. Res. } \\
\text { Hortolândia I - } \\
\text { Tulipas }\end{array}$ & $\begin{array}{l}\text { Minha Casa Minha } \\
\text { Vida II }\end{array}$ & 77 casas & $\begin{array}{l}\text { Faixa } 2 \text { do MCMV. Construtora: } \\
\text { Hortolândia 4A Empreendimento } \\
\text { Imobiliário SPE LTDA. }\end{array}$ \\
\hline 23 & $11 / 2013$ & $\begin{array}{l}\text { Condomínio } \\
\text { Residencial } \\
\text { Girassol }\end{array}$ & $\begin{array}{l}\text { Minha Casa Minha } \\
\text { Vida III }\end{array}$ & 496 apartamentos & $\begin{array}{l}\text { Faixa } 3 \text { do MCMV. Construtora: } \\
\text { Hortolândia QuatroA } \\
\text { Empreendimento Imobiliário SPE } \\
\text { LTDA. }\end{array}$ \\
\hline 24 & $12 / 2013$ & $\begin{array}{l}\text { Portal } \\
\text { Caminhos do } \\
\text { Vento B - } \\
\text { módulo I e II }\end{array}$ & $\begin{array}{l}\text { Minha Casa Minha } \\
\text { Vida II / III }\end{array}$ & 176 apartamentos & $\begin{array}{l}\text { São } 96 \text { apartamentos no módulo I } \\
\text { (faixa 2) e } 80 \text { apartamentos no } \\
\text { módulo II (faixa 3). Construtora: } \\
\text { BRZ Empreendimentos. }\end{array}$ \\
\hline 25 & $02 / 2014$ & $\begin{array}{l}\text { Certto } \\
\text { Hortolândia- } \\
\text { Módulo } 1 \\
\text { (Tons da } \\
\text { Manhã) } \\
\end{array}$ & $\begin{array}{l}\text { Minha Casa Minha } \\
\text { Vida III }\end{array}$ & 100 apartamentos & $\begin{array}{l}\text { Faixa } 3 \text { do MCMV. Construtora: } \\
\text { Plano Macieira Empr. Imobiliários } \\
\text { Ltda. }\end{array}$ \\
\hline 26 & $02 / 2014$ & $\begin{array}{l}\text { Certto } \\
\text { Hortolândia- } \\
\text { Módulo } 1 \\
\text { (Tons da } \\
\text { Tarde) }\end{array}$ & $\begin{array}{l}\text { Minha Casa Minha } \\
\text { Vida II / III }\end{array}$ & 200 apartamentos & $\begin{array}{l}\text { Faixa } 2 \text { ou } 3 \text { do MCMV. } \\
\text { Construtora: Plano Macieira Empr. } \\
\text { Imobiliários Ltda. }\end{array}$ \\
\hline 27 & $03 / 2014$ & $\begin{array}{l}\text { Cond. Recanto } \\
\text { dos Pássaros }\end{array}$ & $\begin{array}{l}\text { Minha Casa Minha } \\
\text { Vida II }\end{array}$ & 28 apartamentos & $\begin{array}{l}\text { Faixa } 2 \text { do MCMV. Construtora: } \\
\text { Ker e Silva Construtora LTDA. }\end{array}$ \\
\hline
\end{tabular}




\begin{tabular}{|c|c|c|c|c|c|}
\hline \multicolumn{6}{|c|}{ Produção Habitacional ${ }^{78}$ de Hortolândia } \\
\hline & $\begin{array}{c}\text { Ano de } \\
\text { entrega }\end{array}$ & $\begin{array}{l}\text { Nome do } \\
\text { Conjunto }\end{array}$ & $\begin{array}{c}\text { Agente financeiro } \\
\text { / Parcerias }\end{array}$ & $\begin{array}{c}\text { No de Unidades } \\
\text { Habitacionais }\end{array}$ & Observações \\
\hline 28 & $08 / 2014$ & $\begin{array}{l}\text { Residencial } \\
\text { Praça das } \\
\text { Árvores }\end{array}$ & $\begin{array}{l}\text { Minha Casa Minha } \\
\text { Vida II / III }\end{array}$ & 96 apartamentos & $\begin{array}{l}\text { Faixa } 2 \text { ou } 3 \text { do MCMV. Barreto \& } \\
\text { Santos Construtora e } \\
\text { Incorporadora Ltda. }\end{array}$ \\
\hline 29 & $09 / 2014$ & $\begin{array}{l}\text { Residencial } \\
\text { Jacuba }\end{array}$ & \begin{tabular}{|l|} 
Programa de \\
Arrendamento \\
Residencial
\end{tabular} & 160 apartamentos & \\
\hline 30 & $12 / 2014$ & $\begin{array}{l}\text { Residencial } \\
\text { Novo Cambuí }\end{array}$ & $\begin{array}{l}\text { Programa Minha } \\
\text { Casa Minha Vida II }\end{array}$ & 32 apartamentos & $\begin{array}{l}\text { Faixa } 2 \text { do MCMV. Construtora } \\
\text { Sega Ltda. }\end{array}$ \\
\hline 31 & 2014 & $\begin{array}{l}\text { Parque } \\
\text { Harvard }\end{array}$ & $\begin{array}{l}\text { Minha Casa Minha } \\
\text { Vida III - Banco do } \\
\text { Brasil }\end{array}$ & 224 apartamentos & $\begin{array}{l}\text { Faixa } 3 \text { do MCMV. Construtora: } \\
\text { MRV MRL XXXII Incorporações } \\
\text { SPE LTDA. }\end{array}$ \\
\hline 32 & $12 / 2014$ & $\begin{array}{l}\text { Vila Flora - } \\
\text { condomínio } 4 \\
\text { (módulo 3) }\end{array}$ & $\begin{array}{l}\text { Minha Casa Minha } \\
\text { Vida III }\end{array}$ & $\begin{array}{l}72 \text { casas e } 24 \\
\text { apartamentos }\end{array}$ & $\begin{array}{l}\text { Faixa } 3 \text { do MCMV. Construtora: } \\
\text { Vila Flora Hortolândia } \\
\text { Empreendimentos Imobiliários } \\
\text { Ltda. }\end{array}$ \\
\hline \multicolumn{4}{|c|}{ Total de Unidades Habitacionais produzidas } & 6.425 & \\
\hline \multicolumn{4}{|c|}{ Total de lotes urbanizados } & & \\
\hline \multicolumn{4}{|c|}{ Total de casas produzidas } & 1.210 & \\
\hline \multicolumn{4}{|c|}{ Total de apartamentos produzidos } & 5.215 & \\
\hline
\end{tabular}

Tabela 13 - Dados das Habitações de Interesse Social produzidas em Indaiatuba ${ }^{80}(1964-$ 2014)

\begin{tabular}{|c|c|c|c|c|c|}
\hline \multicolumn{6}{|c|}{ Produção Habitacional de Indaiatuba } \\
\hline & $\begin{array}{l}\text { Ano de } \\
\text { entrega }\end{array}$ & $\begin{array}{l}\text { Nome do } \\
\text { Conjunto }\end{array}$ & $\begin{array}{c}\text { Agente } \\
\text { financeiro } \\
\text { / Parcerias }\end{array}$ & $\begin{array}{l}\text { No de Unidades } \\
\text { Habitacionais }\end{array}$ & Observações \\
\hline 01 & 1974 & $\begin{array}{l}\text { Vila Castelo } \\
\text { Branco }\end{array}$ & $\mathrm{COHAB}$ & 106 casas & Lei Municipal 1.187/1971. \\
\hline 02 & 1977 & Vila Costa e Silva & $\mathrm{COHAB}$ & 210 casas & Lei Municipal 1.312/1974. \\
\hline 03 & 1978 & $\begin{array}{l}\text { Vila Brigadeiro } \\
\text { Faria Lima I }\end{array}$ & $\mathrm{CDHU}$ & 324 casas & Lei Municipal 1.497/1977. \\
\hline 04 & 1980 & $\begin{array}{l}\text { Vila Brigadeiro } \\
\text { Faria Lima II }\end{array}$ & $\mathrm{CDHU}$ & 320 casas & Lei Municipal 1.497/1977. \\
\hline 05 & 1984 & $\begin{array}{l}\text { Vila Brigadeiro } \\
\text { Faria Lima III } \\
\end{array}$ & $\mathrm{CDHU}$ & 380 casas & Lei Municipal 1.497/1977. \\
\hline 06 & 1986 & $\begin{array}{l}\text { Jardim Tancredo } \\
\text { Neves }\end{array}$ & $\begin{array}{l}\text { Prefeitura } \\
\text { Municipal de } \\
\text { Indaiatuba - } \\
\text { Programa Lotes } \\
\text { Urbanizados } \\
\end{array}$ & 533 lotes & $\begin{array}{l}\text { Lei Municipal 2.218/1986 e } \\
2.869 / 1992 .\end{array}$ \\
\hline 07 & 1987 & $\begin{array}{l}\text { Jardim Teotonio } \\
\text { Vilela }\end{array}$ & $\begin{array}{l}\text { Prefeitura } \\
\text { Municipal de } \\
\text { Indaiatuba - } \\
\text { Programa Lotes } \\
\text { Urbanizados } \\
\end{array}$ & 404 lotes & $\begin{array}{l}\text { Lei Municipal 2.218/1986 e } \\
\text { 2.869/1992. }\end{array}$ \\
\hline
\end{tabular}

${ }^{80}$ Cabe destacar que, ao realizar o levantamento em Indaiatuba, tomou-se conhecimento de um grande empreendimento denominado Campo Limpo (em execução no primeiro semestre de 2015), realizado por meio do Programa Minha Casa Minha Vida, no qual serão entregues 2.048 unidades habitacionais para a faixa 1. 


\begin{tabular}{|c|c|c|c|c|c|}
\hline \multicolumn{6}{|c|}{ Produção Habitacional de Indaiatuba } \\
\hline & $\begin{array}{l}\text { Ano de } \\
\text { entrega }\end{array}$ & $\begin{array}{l}\text { Nome do } \\
\text { Conjunto }\end{array}$ & $\begin{array}{c}\text { Agente } \\
\text { financeiro } \\
\text { / Parcerias }\end{array}$ & $\begin{array}{l}\text { No de Unidades } \\
\text { Habitacionais }\end{array}$ & Observações \\
\hline 08 & 1988 & $\begin{array}{l}\text { Jardim Remulo } \\
\text { Zoppi }\end{array}$ & $\begin{array}{l}\text { Prefeitura } \\
\text { Municipal de } \\
\text { Indaiatuba - } \\
\text { Programa Lotes } \\
\text { Urbanizados }\end{array}$ & 555 lotes & $\begin{array}{l}\text { Lei Municipal 2.218/1986 e } \\
2.869 / 1992 .\end{array}$ \\
\hline 09 & 1988 & $\begin{array}{l}\text { Jardim Juscelino } \\
\text { Kubitschek }\end{array}$ & $\begin{array}{l}\text { Prefeitura } \\
\text { Municipal de } \\
\text { Indaiatuba - } \\
\text { Programa Lotes } \\
\text { Urbanizados } \\
\end{array}$ & 47 lotes & $\begin{array}{l}\text { Lei Municipal 2.218/1986 e } \\
\text { 2.869/1992. }\end{array}$ \\
\hline 10 & 1990 & $\begin{array}{l}\text { Jardim Juscelino } \\
\text { Kubitschek }\end{array}$ & COHAB & 366 casas & Lei Municipal 2.296/1987. \\
\hline 11 & 1993 & $\begin{array}{l}\text { Jardim Carlos } \\
\text { Augusto } \\
\text { Camargo } \\
\text { Andrade I }\end{array}$ & $\begin{array}{l}\text { Prefeitura } \\
\text { Municipal de } \\
\text { Indaiatuba - } \\
\text { Programa Lotes } \\
\text { Urbanizados }\end{array}$ & 192 lotes & $\begin{array}{l}\text { Lei Municipal 2.218/1986 e } \\
\text { 2.869/1992. }\end{array}$ \\
\hline 12 & 1994 & $\begin{array}{l}\text { Jardim Carlos } \\
\text { Augusto } \\
\text { Camargo } \\
\text { Andrade II }\end{array}$ & $\begin{array}{l}\text { Prefeitura } \\
\text { Municipal de } \\
\text { Indaiatuba - } \\
\text { Programa Lotes } \\
\text { Urbanizados }\end{array}$ & 211 lotes & $\begin{array}{l}\text { Lei Municipal 2.218/1986 e } \\
2.869 / 1992 .\end{array}$ \\
\hline 13 & 1996 & $\begin{array}{l}\text { Jardim Lauro } \\
\text { Bueno de } \\
\text { Camargo }\end{array}$ & $\begin{array}{l}\text { Prefeitura } \\
\text { Municipal de } \\
\text { Indaiatuba - } \\
\text { Programa Lotes } \\
\text { Urbanizados }\end{array}$ & 483 lotes & $\begin{array}{l}\text { Lei Municipal 2.218/1986 e } \\
2.869 / 1992 .\end{array}$ \\
\hline 14 & 1996 & $\begin{array}{l}\text { Conjunto Hab. } \\
\text { João Pioli }\end{array}$ & $\mathrm{CDHU}$ & 327 casas & Lei Municipal 3.082/1993. \\
\hline 15 & 1997 & $\begin{array}{l}\text { Conjunto Hab. } \\
\text { Lucio Artoni C1 }\end{array}$ & $\mathrm{CDHU}$ & 584 apartamentos & $\begin{array}{l}\text { Lei Municipal 2.972/1993 e } \\
\text { 2.973/93. }\end{array}$ \\
\hline 16 & 2001 & $\begin{array}{l}\text { Conjunto } \\
\text { Habitacional } \\
\text { Lucio Artoni C2 }\end{array}$ & $\mathrm{CDHU}$ & 80 apartamentos & $\begin{array}{l}\text { Lei Municipal 2.972/1993 e } \\
\text { 2.973/1993. }\end{array}$ \\
\hline 17 & 2003 & $\begin{array}{l}\text { Conjunto } \\
\text { Habitacional } \\
\text { Cocais I }\end{array}$ & $\begin{array}{l}\text { PAR - Programa } \\
\text { de Arrendamento } \\
\text { Residencial }\end{array}$ & 160 apartamentos & Lei Municipal 4.111/2001. \\
\hline 18 & 2003 & $\begin{array}{l}\text { Conjunto } \\
\text { Habitacional } \\
\text { Cocais II } \\
\end{array}$ & $\begin{array}{l}\text { PAR - Programa } \\
\text { de Arrendamento } \\
\text { Residencial }\end{array}$ & 160 apartamentos & Lei Municipal 4.111/2001. \\
\hline 19 & 2004 & $\begin{array}{l}\text { Conjunto } \\
\text { Habitacional } \\
\text { Mirim I }\end{array}$ & $\begin{array}{l}\text { PAR - Programa } \\
\text { de Arrendamento } \\
\text { Residencial }\end{array}$ & 160 apartamentos & Lei Municipal 4.111/2001. \\
\hline 20 & 2005 & $\begin{array}{l}\text { Conjunto } \\
\text { Habitacional } \\
\text { Mirim II }\end{array}$ & $\begin{array}{l}\text { PAR - Programa } \\
\text { de Arrendamento } \\
\text { Residencial }\end{array}$ & 160 apartamentos & Lei Municipal 4.111/2001. \\
\hline 21 & 2005 & $\begin{array}{l}\text { Conjunto } \\
\text { Habitacional } \\
\text { Mario Araldo } \\
\text { Candello }\end{array}$ & $\mathrm{CDHU}$ & 36 casas & $\begin{array}{l}\text { Lei Municipal 4.540/2004 e } \\
4.541 / 2004 .\end{array}$ \\
\hline
\end{tabular}




\begin{tabular}{|c|c|c|c|c|c|}
\hline & \multicolumn{5}{|c|}{ Produção Habitacional de Indaiatuba } \\
\hline & $\begin{array}{l}\text { Ano de } \\
\text { entrega }\end{array}$ & $\begin{array}{l}\text { Nome do } \\
\text { Conjunto }\end{array}$ & \begin{tabular}{|c|} 
Agente \\
financeiro \\
/ Parcerias \\
\end{tabular} & $\begin{array}{l}\text { No de Unidades } \\
\text { Habitacionais }\end{array}$ & Observações \\
\hline 2 & 2007 & $\begin{array}{l}\text { Conjunto } \\
\text { Habitacional } \\
\text { Caminho da Luz }\end{array}$ & $\begin{array}{l}\text { COHAB e PSH } \\
\text { (Programa de } \\
\text { Subsídio } \\
\text { Habitacional / } \\
\text { Federal) } \\
\end{array}$ & 102 casas & $\begin{array}{l}\text { Das } 102 \text { casas, } 100 \text { obtiveram } \\
\text { também o PSH, subsídio do } \\
\text { governo federal. Lei Municipal } \\
4.731 / 2005 .\end{array}$ \\
\hline 23 & 2010 & $\begin{array}{l}\text { Condomínio } \\
\text { Residencial Portal } \\
\text { das Cerejeiras }\end{array}$ & \begin{tabular}{|l|} 
CHI - Cooperativa \\
Habitacional de \\
Indaiatuba e \\
Prefeitura \\
Municipal
\end{tabular} & 80 apartamentos & $\begin{array}{l}\text { A prefeitura doou a área para a } \\
\text { Cooperativa, parceira no projeto, } \\
\text { e ainda indicou a demanda. Lei } \\
\text { Municipal } 5.111 / 2007 \text { e } \\
5.191 / 2007 .\end{array}$ \\
\hline 4 & 2010 & $\begin{array}{l}\text { Condomínio } \\
\text { Residencial Portal } \\
\text { dos Jacarandas }\end{array}$ & \begin{tabular}{|l|} 
CHI - Cooperativa \\
Habitacional de \\
Indaiatuba e \\
Prefeitura \\
Municipal \\
\end{tabular} & 64 apartamentos & $\begin{array}{l}\text { A prefeitura doou a área para a } \\
\text { Cooperativa, parceira no projeto, } \\
\text { e ainda indicou a demanda. Lei } \\
\text { Municipal } 5.111 / 2007 \text { e } \\
5.191 / 2007 \text {. }\end{array}$ \\
\hline 25 & 2010 & $\begin{array}{l}\text { Conjunto } \\
\text { Habitacional } \\
\text { Veredas da } \\
\text { Conquista }\end{array}$ & COHAB & 108 casas & $\begin{array}{l}\text { Lei Municipal } 4.731 / 2005 \mathrm{e} \\
5.631 / 2009 .\end{array}$ \\
\hline 26 & 2012 & $\begin{array}{l}\text { Jardim dos } \\
\text { Colibris }\end{array}$ & $\begin{array}{l}\text { Programa MCMV } \\
\text { II - Iniciativa } \\
\text { Privada / Caixa } \\
\text { Econômica } \\
\text { Federal / } \\
\text { Prefeitura } \\
\text { Municipal }\end{array}$ & 500 casas & $\begin{array}{l}\text { Faixa } 2 \text { do MCMV. O Jd. dos } \\
\text { Colibris foi realizado pela iniciativa } \\
\text { privada e os imóveis puderam ser } \\
\text { financiados pela Caixa, por meio } \\
\text { do Programa Minha Casa Minha } \\
\text { Vida, com subsídios e demais } \\
\text { condicionantes do programa, } \\
\text { obtendo ainda as isenções da } \\
\text { prefeitura, conforme a Lei } \\
\text { Municipal } 5.762 / 2010 \text {. }\end{array}$ \\
\hline 7 & $04 / 2013$ & Spazio Illuminare & $\begin{array}{l}\text { Programa Minha } \\
\text { Casa Minha Vida } \\
\text { II }\end{array}$ & 408 apartamentos & $\begin{array}{l}\text { Faixa } 2 \text { do MCMV. Construtora: } \\
\text { MRV engenharia e participações } \\
\text { AS. }\end{array}$ \\
\hline & 2014 & $\begin{array}{l}\text { Residencial } \\
\text { Tamoios I }\end{array}$ & $\begin{array}{l}\text { Programa Minha } \\
\text { Casa Minha Vida I }\end{array}$ & $\begin{array}{l}24 \text { casas } \\
\text { sobrepostas }\end{array}$ & $\begin{array}{l}\text { Faixa } 1 \text { do MCMV. Lei Municipal } \\
5.111 / 2007 \text { e 5.191/2007. }\end{array}$ \\
\hline & 2014 & $\begin{array}{l}\text { Residencial } \\
\text { Tamoios II }\end{array}$ & \begin{tabular}{|l|} 
Programa Minha \\
Casa Minha Vida I
\end{tabular} & $\begin{array}{l}56 \text { casas } \\
\text { sobrepostas }\end{array}$ & $\begin{array}{l}\text { Faixa } 1 \text { do MCMV. Lei Municipal } \\
5.111 / 2007 \text { e 5.191/2007. }\end{array}$ \\
\hline & $\begin{array}{l}\text { Total de } \\
\text { produzic }\end{array}$ & $\begin{array}{l}\text { Unidades Habit } \\
\text { das }\end{array}$ & acionais & 7.140 & \\
\hline & Total de I & lotes urbanizados & & 2.425 & \\
\hline & Total de & casas produzidas & & 2.859 & \\
\hline & Total de & apartamentos prod & duzidos & 1.856 & \\
\hline
\end{tabular}


Tabela 14 - Dados das Habitações de Interesse Social produzidas em Itatiba ${ }^{81}$ (1964-2014)

\begin{tabular}{|c|c|c|c|c|c|}
\hline \multicolumn{6}{|c|}{ Produção Habitacional de Itatiba } \\
\hline & $\begin{array}{l}\text { Ano de } \\
\text { entrega }\end{array}$ & $\begin{array}{l}\text { Nome do } \\
\text { Conjunto }\end{array}$ & $\begin{array}{l}\text { Agente financeiro } \\
\text { / Parcerias }\end{array}$ & \begin{tabular}{|c|}
$N^{0}$ de \\
Unidades \\
Habitacionais \\
\end{tabular} & Observações \\
\hline 1 & 1976 & $\begin{array}{l}\text { Núcleo Residencial } \\
\text { Afonso Zupardo }\end{array}$ & COHAB Bandeirantes & 224 casas & \\
\hline 2 & 1976 & $\begin{array}{l}\text { Núcleo Residencial } \\
\text { Carlos Borella }\end{array}$ & COHAB Bandeirantes & 77 casas & \\
\hline 3 & 1978 & Jardim Harmonia & COHAB Bandeirantes & 219 casas & \\
\hline 4 & 1984 & $\begin{array}{l}\text { Núcleo Residencial } \\
\text { Abramo Delforno }\end{array}$ & $\begin{array}{l}\text { Prefeitura Municipal } \\
\text { de Itatiba }\end{array}$ & 253 casas & $\begin{array}{l}\text { Projeto realizado na época pela } \\
\text { EMUHTA - Empresa Municipal } \\
\text { de Habitação de Itatiba }\end{array}$ \\
\hline 5 & 1986 & $\begin{array}{l}\text { Núcleo Residencial } \\
\text { Dr. Luiz Mattos } \\
\text { Pimenta (CECAP) } \\
\end{array}$ & \multirow{2}{*}{$\begin{array}{l}\text { CDH (Companhia de } \\
\text { Habitação do Estado } \\
\text { de São Paulo) }\end{array}$} & 449 casas & \\
\hline 6 & 1988 & $\begin{array}{l}\text { Núcleo Residencial } \\
\text { Porto Seguro }\end{array}$ & & 348 casas & \\
\hline 7 & 1988 & $\begin{array}{l}\text { Núcleo Residencial } \\
\text { Pedro Fumachi }\end{array}$ & $\begin{array}{l}\text { Prefeitura Municipal } \\
\text { de Itatiba }\end{array}$ & 102 casas & $\begin{array}{l}\text { Projeto realizado na época pela } \\
\text { EMUHTA - Empresa Municipal } \\
\text { de Habitação de Itatiba }\end{array}$ \\
\hline 8 & 1990 & $\begin{array}{l}\text { Núcleo Residencial } \\
\text { Corradine I }\end{array}$ & COHAB Bandeirantes & 63 casas & \\
\hline 9 & 1991 & $\begin{array}{l}\text { Núcleo Residencial } \\
\text { Corradine II }\end{array}$ & COHAB Bandeirantes & $\begin{array}{r}176 \\
\text { apartamentos }\end{array}$ & \\
\hline 0 & 1993 & $\begin{array}{l}\text { Núcleo Res. } \\
\text { Roberto Panzarin } \\
\text { (JATOBÁ) } \\
\text { Conjunto } \\
\text { Habitacional } \\
\text { Fioravante Polessi } \\
\end{array}$ & $\mathrm{CDHU}$ & $\begin{array}{r}240 \\
\text { apartamentos } \mathrm{e} \\
14 \text { casas }\end{array}$ & $\begin{array}{l}\text { OBS: Totalizam } 254 \text { unidades } \\
\text { habitacionais. }\end{array}$ \\
\hline 1 & 1999 & \begin{tabular}{|l|} 
Núcleo Residencial \\
Pedro Costa
\end{tabular} & $\mathrm{CDHU}$ & $\begin{array}{r}920 \\
\text { apartamentos } \\
\end{array}$ & \\
\hline 2 & 2000 & $\begin{array}{l}\text { Núcleo Residencial } \\
\text { Erasmo Chrispin }\end{array}$ & $\mathrm{CDHU}$ & 191 casas & \\
\hline 3 & 2000 & $\begin{array}{l}\text { Conj. Res. Martha } \\
\text { Colicini Catalano }\end{array}$ & $\mathrm{CDHU}$ & $\begin{array}{r}120 \\
\text { apartamentos }\end{array}$ & \\
\hline 4 & 2003 & $\begin{array}{l}\text { Núcleo Residencial } \\
\text { João Maggi }\end{array}$ & $\mathrm{CDHU}$ & $\begin{array}{r}1.304 \\
\text { apartamentos }\end{array}$ & \\
\hline 5 & 2006 & $\begin{array}{l}\text { Núcleo Residencial } \\
\text { Fumachi }\end{array}$ & $\begin{array}{l}\text { PAR e CEF (Caixa } \\
\text { Econômica Federal) }\end{array}$ & $\begin{array}{r}162 \\
\text { apartamentos } \\
\end{array}$ & $\begin{array}{l}\text { PAR-Programa de Arrendamento } \\
\text { Residencial. }\end{array}$ \\
\hline 6 & 2006 & $\begin{array}{l}\text { Núcleo Residencial } \\
\text { Ouro }\end{array}$ & $\begin{array}{l}\text { PAR e CEF (Caixa } \\
\text { Econômica Federal) }\end{array}$ & $\begin{array}{r}180 \\
\text { apartamentos }\end{array}$ & $\begin{array}{l}\text { PAR-Programa de Arrendamento } \\
\text { Residencial. }\end{array}$ \\
\hline 7 & $08 / 2011$ & $\begin{array}{l}\text { Residencial Terra } \\
\text { Nova }\end{array}$ & $\begin{array}{l}\text { Minha Casa Minha } \\
\text { Vida III }\end{array}$ & 29 casas & $\begin{array}{l}\text { Faixa } 3 \text { do MCMV. Construtora: } \\
\text { Maubertec Empreend. }\end{array}$ \\
\hline 8 & $11 / 2013$ & $\begin{array}{l}\text { Residencial } \\
\text { Fernanda }\end{array}$ & $\begin{array}{l}\text { Programa Minha Casa } \\
\text { Minha Vida III }\end{array}$ & 72 apartamentos & $\begin{array}{l}\text { Faixa } 3 \text { do MCMV. Construtora: } \\
\text { Toreti Empreendimentos } \\
\text { Imobiliarios LTDA. }\end{array}$ \\
\hline \multicolumn{4}{|c|}{ Total de Unidades Habitacionais produzidas } & 5.143 & \\
\hline \multirow{3}{*}{\multicolumn{4}{|c|}{\begin{tabular}{|l|} 
Total de lotes urbanizados \\
Total de casas produzidas \\
Total de apartamentos produzidos \\
\end{tabular}}} & & \\
\hline & & & & 1.969 & \\
\hline & & & & 3.174 & \\
\hline
\end{tabular}

81 Quando ocorreu o levantamento, tomou-se conhecimento do empreendimento Up Tower Ponte, 83 apartamentos, faixa 2 do MCMV, entretanto, este não consta na tabela por ter sido entregue em 2015. 
Tabela 15 - Dados das Habitações de Interesse Social produzidas em Jaguariúna (1964-2014)

\begin{tabular}{|c|c|c|c|c|}
\hline \multicolumn{5}{|c|}{ Produção Habitacional de Jaguariúna } \\
\hline $\begin{array}{l}\text { Ano de } \\
\text { entrega }\end{array}$ & $\begin{array}{l}\text { Nome do } \\
\text { Conjunto }\end{array}$ & $\begin{array}{c}\text { Agente financeiro } \\
\text { / Parcerias }\end{array}$ & $\begin{array}{l}\text { No de Unidades } \\
\text { Habitacionais }\end{array}$ & Observações \\
\hline 1975 & $\begin{array}{l}\text { Vila } 7 \text { de } \\
\text { setembro }\end{array}$ & COHAB Bandeirante & 70 casas & \\
\hline 1980 & Vila São Francisco & INOCOOP São Paulo & 127 casas & \\
\hline 1982 & $\begin{array}{l}\text { Vila Dr. João Aldo } \\
\text { Nassif }\end{array}$ & $\begin{array}{l}\text { Caixa Econômica Federal e } \\
\text { iniciativa privada }\end{array}$ & 500 casas & $\begin{array}{l}\text { Construção } \\
\text { financiada pela C.E.F. } \\
\text { Execução e venda } \\
\text { por empresa } \\
\text { particular. }\end{array}$ \\
\hline 1988 & Vila São José & $\begin{array}{l}\text { Caixa Econômica Federal e } \\
\text { iniciativa privada }\end{array}$ & 332 casas & $\begin{array}{l}\text { Construção } \\
\text { financiada pela C.E.F. } \\
\text { Execução e venda } \\
\text { por empresa } \\
\text { particular. }\end{array}$ \\
\hline 1988 & \begin{tabular}{|l} 
Vila 12 de \\
Setembro I Etapa
\end{tabular} & COHAB Bandeirante & 119 casas & \\
\hline 1990 & $\begin{array}{l}\text { Vila Guilherme } \\
\text { Giesbrecht }\end{array}$ & $\mathrm{CDHU}$ & 118 casas & \\
\hline 1992 & \begin{tabular}{|l|} 
Vila 12 de \\
Setembro II Etapa
\end{tabular} & COHAB Bandeirante & 178 casas & \\
\hline 1992 & Vila Miguel Martini & $\mathrm{CDHU}$ & 221 casas & \\
\hline 2005 & Jardim Pinheiros & $\begin{array}{l}\text { COHAB Bandeirante e Fundo } \\
\text { Municipal de Habitação }\end{array}$ & 117 casas & \\
\hline 2008 & $\begin{array}{l}\text { Recanto dos } \\
\text { Pássaros }\end{array}$ & $\begin{array}{l}\text { PAR (Programa de } \\
\text { Arrendamento Residencial) e } \\
\text { Caixa Econômica Federal }\end{array}$ & 192 apartamentos & \\
\hline 2009 & $\begin{array}{l}\text { Quinta das } \\
\text { Laranjeiras }\end{array}$ & $\begin{array}{l}\text { Minha Casa Minha Vida III e } \\
\text { Caixa Econômica Federal }\end{array}$ & 108 casas & Faixa 3 do MCMV. \\
\hline 2012 & Quinta do Conde & $\begin{array}{l}\text { Minha Casa Minha Vida III e } \\
\text { Caixa Econômica Federal }\end{array}$ & 336 apartamentos & Faixa 3 do MCMV. \\
\hline 2013 & $\begin{array}{l}\text { Quinta das } \\
\text { Pitangueiras }\end{array}$ & $\begin{array}{l}\text { Minha Casa Minha Vida III e } \\
\text { Caixa Econômica Federal }\end{array}$ & 672 apartamentos & Faixa 3 do MCMV. \\
\hline 2013 & $\begin{array}{l}\text { Condomínio } \\
\text { Residencial } \\
\text { Jaguariúna I }\end{array}$ & Minha Casa Minha Vida I & 396 apartamentos & \begin{tabular}{|l|} 
Faixa 1 do MCMV \\
(modalidade: FAR - \\
Fundo de \\
Arrendamento \\
Residencial).
\end{tabular} \\
\hline 2014 & $\begin{array}{l}\text { Condomínio } \\
\text { Residencial } \\
\text { Jaguariúna II }\end{array}$ & Minha Casa Minha Vida I & 400 apartamentos & $\begin{array}{l}\text { Faixa } 1 \text { do MCMV } \\
\text { (modalidade: FAR - } \\
\text { Fundo de } \\
\text { Arrendamento } \\
\text { Residencial). }\end{array}$ \\
\hline Total de & Unidades Habita & cionais produzidas & 3.886 & \\
\hline Total de $\mathrm{c}$ & casas produzidas & & 1.890 & \\
\hline Total de lc & otes urbanizados p & roduzidos & 0 & \\
\hline Total de A & Apartamentos prod & uzidos & 1.996 & \\
\hline
\end{tabular}


Tabela 16 - Dados das Habitações de Interesse Social produzidas em Monte Mor ${ }^{82}$ (1964$\underline{2014)}$

\begin{tabular}{|c|c|c|c|c|c|}
\hline \multicolumn{6}{|c|}{ Produção Habitacional de Monte Mor } \\
\hline & $\begin{array}{l}\text { Ano de } \\
\text { entrega }\end{array}$ & Nome do Conjunto & $\begin{array}{c}\text { Agente financeiro } \\
\text { / Parcerias }\end{array}$ & $\begin{array}{c}\text { No de Unidades } \\
\text { Habitacionais }\end{array}$ & Observações \\
\hline & 1975 & $\begin{array}{l}\text { Conjunto Habitacional } \\
\text { Dona Maria Bueno } \\
\text { Carneiro }\end{array}$ & $\mathrm{COHAB}$ & 57 Casas & Área total: $23.461 \mathrm{~m}^{2}$ \\
\hline & 1993 & $\begin{array}{l}\text { Conjunto Habitacional } \\
\text { Monte Mor B (Maria } \\
\text { Aparecida Barreto Giatti) }\end{array}$ & $\mathrm{CDHU}$ & 202 Casas & \\
\hline & 2006 & $\begin{array}{l}\text { Conjunto Habitacional } \\
\text { Monte Mor C (Jd. Vitória) }\end{array}$ & $\mathrm{CDHU}$ & 298 Casas & $\begin{array}{l}\text { Área total do conjunto: } \\
60.423,71 \mathrm{~m}^{2} \text {. }\end{array}$ \\
\hline \multicolumn{4}{|c|}{ Total de Unidades Habitacionais produzidas } & 557 & \\
\hline \multicolumn{4}{|c|}{ Total de casas produzidas } & 557 & \\
\hline \multicolumn{4}{|c|}{ Total de lotes urbanizados produzidos } & 0 & \\
\hline \multicolumn{4}{|c|}{ Total de apartamentos produzidos } & 0 & \\
\hline
\end{tabular}

Tabela 17 - Dados das Habitações de Interesse Social produzidas em Morungaba (19642014)

\begin{tabular}{|c|c|c|c|c|}
\hline \multicolumn{5}{|c|}{ Produção Habitacional de Morungaba } \\
\hline \begin{tabular}{|c|} 
Ano de \\
entrega
\end{tabular} & Nome do Conjunto & $\begin{array}{c}\text { Agente financeiro } \\
\text { / Parcerias }\end{array}$ & $\begin{array}{l}\text { No de Unidades } \\
\text { Habitacionais }\end{array}$ & Observações \\
\hline 1978 & $\begin{array}{l}\text { Núcleo Habitacional } \\
\text { José Consolim }\end{array}$ & CECAP $^{83}$ & 44 casas & \\
\hline 1988 & $\begin{array}{l}\text { Núcleo Habitacional } \\
\text { Brumado I }\end{array}$ & $\begin{array}{l}\text { Prefeitura Municipal } \\
\text { de Morungaba }\end{array}$ & 153 casas & $\begin{array}{l}\text { A prefeitura doou o terreno } \\
\text { e material e os munícipes } \\
\text { colaboraram com a mão-de- } \\
\text { obra. }\end{array}$ \\
\hline 1991 & $\begin{array}{l}\text { Núcleo Habitacional } \\
\text { Barra Mansa }\end{array}$ & $\mathrm{COHAB}$ & 147 casas & \\
\hline 2002 & $\begin{array}{l}\text { Núcleo Habitacional } \\
\text { Brumado II }\end{array}$ & $\begin{array}{l}\text { Prefeitura Municipal } \\
\text { de Morungaba e } \\
\text { Caixa Econômica } \\
\text { Federal }\end{array}$ & 107 casas & $\begin{array}{l}\text { As } 107 \text { casas foram } \\
\text { financiadas pela Caixa } \\
\text { Econômica Federal, os } 84 \\
\text { lotes foram sorteados e } \\
\text { doados aos munícipes (a } \\
\text { construção foi realizada } \\
\text { pelos contemplados). }\end{array}$ \\
\hline \multicolumn{3}{|c|}{ Total de Unidades Habitacionais produzidas } & 535 & \\
\hline \multicolumn{3}{|c|}{ Total de casas produzidas } & 451 & \\
\hline \multicolumn{3}{|c|}{ Total de lotes urbanizados produzidos } & 84 & \\
\hline \multicolumn{3}{|c|}{ Total de apartamentos produzidos } & 0 & \\
\hline
\end{tabular}

82 Ao realizar o levantamento da produção de Habitação de Interesse Social de Monte Mor, tomou-se conhecimento do empreendimento Residencial Flamboyant e Pitangueiras, cuja produção será de 600 unidades habitacionais, entretanto, este não consta da tabela por ser posterior ao período pesquisado, com previsão de entrega das unidades para 2016.

${ }^{83}$ A CECAP (Companhia Estadual de Casas Populares) foi o primeiro nome da empresa CDHU, e sua fundação ocorreu em 1949. Entretanto, a produção de habitações para a população de baixa renda inicia-se em 1967 (Fonte: site da CDHU). 
Tabela 18 - Dados das Habitações de Interesse Social produzidas em Nova Odessa (19642014)

\begin{tabular}{|c|c|c|c|c|c|}
\hline \multicolumn{6}{|c|}{ Produção Habitacional de Nova Odessa } \\
\hline & $\begin{array}{l}\text { Ano de } \\
\text { entrega }\end{array}$ & $\begin{array}{l}\text { Nome do } \\
\text { Conjunto }\end{array}$ & $\begin{array}{l}\text { Agente } \\
\text { financeiro } \\
\text { / Parcerias }\end{array}$ & $\begin{array}{l}\text { No de Unidades } \\
\text { Habitacionais }\end{array}$ & Observações \\
\hline 01 & 1978 & $\begin{array}{l}\text { Conjunto } \\
\text { Residencial } \\
\text { Maria Raposeiro } \\
\text { Azenha }\end{array}$ & $\begin{array}{l}\text { COHAB } \\
\text { Bandeirante }\end{array}$ & 99 casas & \\
\hline 02 & 1980 & $\begin{array}{l}\text { Conjunto } \\
\text { Residencial } \\
\text { Matilde Berzin }\end{array}$ & $\begin{array}{l}\mathrm{COHAB} \\
\text { Bandeirante }\end{array}$ & 235 casas & \\
\hline 03 & 1982 & \begin{tabular}{|l|} 
Conjunto \\
Residencial \\
Triunfo
\end{tabular} & $\begin{array}{l}\text { COHAB } \\
\text { Bandeirante }\end{array}$ & 321 casas & \\
\hline 04 & 1990 & $\begin{array}{l}\text { Conjunto } \\
\text { Residencial } 23 \\
\text { de Maio } \\
\end{array}$ & $\begin{array}{l}\mathrm{COHAB} \\
\text { Bandeirante }\end{array}$ & 162 casas & \\
\hline 05 & 1997 & \begin{tabular}{|l} 
Jardim das \\
Palmeiras
\end{tabular} & $\mathrm{CDHU}$ & 296 casas & \\
\hline 06 & 2002 & $\begin{array}{l}\text { Jardim dos } \\
\text { Jequitibás }\end{array}$ & $\begin{array}{l}\text { Programa de } \\
\text { Arrendamento } \\
\text { Residencial - PAR }\end{array}$ & 581 casas & \\
\hline 07 & 2003 & $\begin{array}{l}\text { Monte das } \\
\text { Oliveiras }\end{array}$ & $\begin{array}{l}\text { Programa de } \\
\text { Arrendamento } \\
\text { Residencial - PAR }\end{array}$ & 459 casas & \\
\hline 08 & 2004 & Campos Verdes & $\begin{array}{l}\text { PAR (associativo } \\
\text { ao FGTS) }\end{array}$ & 645 casas & \\
\hline 09 & $06 / 2013$ & $\begin{array}{l}\text { Res. Jardim } \\
\text { Fibra - fase } 1\end{array}$ & $\begin{array}{l}\text { Minha Casa Minha } \\
\text { Vida II }\end{array}$ & 333 casas & $\begin{array}{l}\text { Faixa } 2 \text { do MCMV. Construtora: } \\
\text { Partifib Projetos Imobiliários } \\
\text { Sitio Triunfo Ltda. }\end{array}$ \\
\hline 10 & $06 / 2013$ & $\begin{array}{l}\text { Res. Jardim } \\
\text { Fibra - fase } 2\end{array}$ & $\begin{array}{l}\text { Minha Casa Minha } \\
\text { Vida II }\end{array}$ & 256 casas & $\begin{array}{l}\text { Faixa } 2 \text { do MCMV. Construtora: } \\
\text { Partifib Projetos Imobiliários } \\
\text { Sitio Triunfo Ltda. }\end{array}$ \\
\hline 11 & $07 / 2013$ & $\begin{array}{l}\text { Res. Jardim } \\
\text { Fibra }\end{array}$ & MCMV 1 (FAR) & 144 casas & $\begin{array}{l}\text { Faixa } 1 \text { do MCMV. Construtora: } \\
\text { Torres Engenhar. }\end{array}$ \\
\hline & Total de Un & idades Habitaci & ionais produzidas & 3.531 & \\
\hline & Total de casa & as produzidas & & 3.531 & \\
\hline & Total de lote & s urbanizados proc & duzidos & 0 & \\
\hline & Total de apa & itamentos produzi & & 0 & \\
\hline
\end{tabular}


Tabela 19 - Dados das Habitações de Interesse Social produzidas em Paulínia (1964-2014)

\begin{tabular}{|c|c|c|c|c|}
\hline \multicolumn{5}{|c|}{ Produção Habitacional de Paulínia } \\
\hline $\begin{array}{l}\text { Ano de } \\
\text { entrega }\end{array}$ & $\begin{array}{l}\text { Nome do } \\
\text { Conjunto }\end{array}$ & $\begin{array}{l}\text { Agente } \\
\text { financeiro } \\
\text { / Parcerias }\end{array}$ & $\begin{array}{c}\text { No de } \\
\text { Unidades } \\
\text { Habitacionais }\end{array}$ & Observações \\
\hline $1970-80$ & $\begin{array}{l}\text { José Paulino } \\
\text { Nogueira }\end{array}$ & COHAB & 246 casas & $\begin{array}{l}\text { Decreto de aprovação no 309/1970. Área } \\
\text { total: } 120.076,76 \text { m². }^{2}\end{array}$ \\
\hline 1975 & $\begin{array}{l}\text { Jd. } \\
\text { Primavera }\end{array}$ & $\begin{array}{l}\text { COHAB } \\
\text { Bandeirantes e } \\
\text { Caixa }\end{array}$ & 455 casas & $\begin{array}{l}\text { Decreto } 841 / 75 \text {. O financimento foi } \\
\text { realizado pela CAIXA. Área total: } \\
273.460,00 \mathrm{~m}^{2} \text {. }\end{array}$ \\
\hline 1975 & $\begin{array}{l}\text { Presidente } \\
\text { Medici }\end{array}$ & COHAB & 198 casas & $\begin{array}{l}\text { Decreto de aprovação no 858/1975. Área } \\
\text { total: } 93.631,80 \mathrm{~m}^{2} \text {. }\end{array}$ \\
\hline 1980 & $\begin{array}{l}\text { Jardim } \\
\text { Flamboyant }\end{array}$ & $\begin{array}{l}\text { Prefeitura } \\
\text { Municipal de } \\
\text { Paulínia }\end{array}$ & 301 casas & $\begin{array}{l}\text { Decreto de aprovação: } 713 / 80 \text {. Houve } \\
\text { doação das casas para os munícipes. São } \\
210 \text { casas com } 50 \mathrm{~m}^{2} \text { ( } 3 \text { dormitórios) e } 91 \\
\text { casas com } 41,13 \mathrm{~m}^{2} \text { ( } 2 \text { dormitórios). Área } \\
\text { total: } 97.000,00 \mathrm{~m}^{2} \text {. }\end{array}$ \\
\hline 1982 & $\begin{array}{l}\text { Jd. Monte } \\
\text { Alegre I }\end{array}$ & \begin{tabular}{|l|} 
COHAB \\
Bandeirantes
\end{tabular} & 502 casas $\left.\right|_{t}$ & $\begin{array}{l}\text { Decreto de aprovação: } 1.596 / 1982 \text {. Área } \\
\text { total: } 276.615,34 \mathrm{~m}^{2} \text {. }\end{array}$ \\
\hline 1982 & $\begin{array}{l}\text { Jd. Monte } \\
\text { Alegre II }\end{array}$ & $\begin{array}{l}\text { COHAB } \\
\text { Bandeirantes }\end{array}$ & 233 casas $\left.\right|_{t}$ & $\begin{array}{l}\text { Decreto de aprovação: } 1.596 / 1982 \text {. Área } \\
\text { total: } 93.007,30 \mathrm{~m}^{2} \text {. }\end{array}$ \\
\hline 1983-95 & $\begin{array}{l}\text { Jd. Ouro } \\
\text { Negro }\end{array}$ & $\begin{array}{l}\text { Prefeitura de } \\
\text { Paulínia e } \\
\text { INOCOOP }\end{array}$ & 256 casas & $\begin{array}{l}\text { Decreto: } 816 / 1983 \text {. A cooperativa iniciou e } \\
\text { a prefeitura finalizou a obra. Área } \\
123.740,00 \mathrm{~m}^{2} \text {. }\end{array}$ \\
\hline 1987-89 & $\begin{array}{l}\text { Edith } \\
\text { Campos } \\
\text { Fávero (Jd. } \\
\text { Morro Alto) }\end{array}$ & $\begin{array}{l}\text { Prefeitura } \\
\text { Municipal de } \\
\text { Paulínia }\end{array}$ & 599 casas & $\begin{array}{l}\text { A prefeitura doou os terrenos e as plantas, } \\
\text { e houve sistema de mutirão para as } \\
\text { construções. Decreto de aprovação: } \\
\text { 2.258/1987. Área total: } 221.103,00 \mathrm{~m}^{2} \text {. }\end{array}$ \\
\hline $1992^{84}$ & Jequetibá I & $\begin{array}{l}\text { Prefeitura } \\
\text { Municipal de } \\
\text { Paulínia } \\
\end{array}$ & 50 casas & $\begin{array}{l}\text { Houve doação das casas para os munícipes. } \\
\text { Decreto de aprovação: } 6.182 / 2012 \text {. Área } \\
\text { total: } 11.965,99 \mathrm{~m}^{2} \text {. }\end{array}$ \\
\hline 1992 & $\begin{array}{l}\text { Jd. Monte } \\
\text { Alegre III }\end{array}$ & $\begin{array}{l}\mathrm{COHAB}, \\
\text { Prefeitura e } \\
\text { Paulínia e CEF }\end{array}$ & 335 casas & $\begin{array}{l}\text { Decreto de aprovação no } 3.096 / 1992 \text {. Área } \\
\text { total: } 160.422,09 \text { m². }^{2} \text {. }\end{array}$ \\
\hline 1993-97 & $\begin{array}{l}\text { Jd. Monte } \\
\text { Alegre IV }\end{array}$ & $\begin{array}{l}\text { COHAB } \\
\text { Bandeirantes e } \\
\text { Prefeitura de } \\
\text { Paulínia }\end{array}$ & 456 casas & $\begin{array}{l}\text { Decreto de aprovação: } 3.273 / 1993 \text {. Área } \\
\text { total: } 188.918,46 \mathrm{~m}^{2} \text {. }\end{array}$ \\
\hline 1993-99 & $\begin{array}{l}\text { Jd. Monte } \\
\text { Alegre V }\end{array}$ & $\begin{array}{l}\text { COHAB } \\
\text { Bandeirantes e } \\
\text { Prefeitura de } \\
\text { Paulínia }\end{array}$ & 248 casas & $\begin{array}{l}\text { Decreto de aprovação: } 3.273 / 1993 \text {. Área } \\
\text { total: } 67.585,60 \mathrm{~m}^{2} \text {. }\end{array}$ \\
\hline $1996^{85}$ & Jd. Leonor & $\begin{array}{l}\text { Prefeitura de } \\
\text { Paulínia }\end{array}$ & $\begin{array}{r}318 \text { casas e } 263 \\
\text { lotes } \\
\text { urbanizados }\end{array}$ & $\begin{array}{l}\text { Houve doação de lotes e casas para os } \\
\text { munícipes. Decreto de aprovação: } \\
6.183 / 2012 \text {. Área total: } 320.709,55 \mathrm{~m}^{2} \text {. }\end{array}$ \\
\hline 1997 & $\begin{array}{l}\text { Jequetibá II } \\
\text { / Paulínia A }\end{array}$ & $\begin{array}{l}\text { CDHU e } \\
\text { Prefeitura de } \\
\text { Paulínia }\end{array}$ & 210 casas & \\
\hline
\end{tabular}

\footnotetext{
${ }^{84}$ A regularização fundiária do Jequetibá I ocorreu em 2012.

${ }^{85}$ A regularização fundiária do Jardim Leonor ocorreu em 2012.
} 


\begin{tabular}{|c|c|c|c|c|c|}
\hline \multicolumn{6}{|c|}{ Produção Habitacional de Paulínia } \\
\hline & $\begin{array}{c}\text { Ano de } \\
\text { entrega }\end{array}$ & $\begin{array}{l}\text { Nome do } \\
\text { Conjunto }\end{array}$ & $\begin{array}{l}\text { Agente } \\
\text { financeiro } \\
\text { / Parcerias }\end{array}$ & \begin{tabular}{|c|}
$N^{\circ}$ de \\
Unidades \\
Habitacionais
\end{tabular} & Observações \\
\hline 15 & 1999 & $\begin{array}{l}\text { Jd. Res. } \\
\text { Tereza Z. } \\
\text { Vedovello - } \\
\text { Cooperlotes }\end{array}$ & $\begin{array}{l}\text { Cooperativa } \\
\text { Regional de } \\
\text { Habitação } \\
\text { Popular e } \\
\text { Prefeitura }\end{array}$ & 1.343 casas & $\begin{array}{l}\text { A Cooperativa comprou a área e realizou o } \\
\text { empreendimento; a prefeitura contribuiu } \\
\text { com a aprovação da Lei } 2.157 / 1999 \text {, que } \\
\text { permitiu requisitos diferenciados para HIS, } \\
\text { e realizou obras de pavimentação em parte } \\
\text { da Avenida Antônio Baptista Piva (PLN- } \\
\text { 030). Dec. de aprovação: } 4.618 / 1999 \text {. Área } \\
\text { total: } 466.267,68 \text { m². }^{2}\end{array}$ \\
\hline 16 & 2000 & $\begin{array}{l}\text { Jd. Amélia } \\
\text { Duarte } \\
\text { Quintal }\end{array}$ & $\begin{array}{l}\text { Prefeitura } \\
\text { Municipal de } \\
\text { Paulínia }\end{array}$ & $\begin{array}{r}150 \text { casas e } 188 \\
\text { lotes } \\
\text { urbanizados }\end{array}$ & $\begin{array}{l}\text { Decreto de aprovação: } 4756 / 2000 \text {. Houve } \\
\text { doação das casas e lotes para os } \\
\text { munícipes. Em } 2015 \text {, o Jd. Amélia Duarte } \\
\text { passa por processo de regularização } \\
\text { fundiária. Área total: } 288.954,61 \mathrm{~m}^{2} \text {. }\end{array}$ \\
\hline 17 & 2005 & Serra Azul & $\begin{array}{l}\text { Prefeitura } \\
\text { Municipal de } \\
\text { Paulínia }\end{array}$ & 10 casas & $\begin{array}{l}\text { O loteamento foi particular (total de } 497 \\
\text { casas em } 2000 \text { ), e a prefeitura adquiriu } 10 \\
\text { casas para atender habitações } \\
\text { emergenciais (a prefeitura talvez compre } \\
\text { mais casas para a mesma situação). Os } \\
\text { Decretos } 5.339,5.311,5.272 \text { e } 5.271 \text { de } \\
2005 \text { aprovam a desapropriação das } 10 \\
\text { casas. Portanto, considerou-se o ano de } \\
2005 \text {. }\end{array}$ \\
\hline 18 & 2011 & Padovani & MCMV III & $\begin{array}{r}176 \\
\text { apartamentos }\end{array}$ & $\begin{array}{l}\text { Faixa } 3 \text { do MCMV. No do decreto: } 6.032 \text { de } \\
\text { 10/01/2011. Área construída: } 8.486,73 \mathrm{~m}^{2} \text {. } \\
\text { MRV Engenharia e Participações S/A. }\end{array}$ \\
\hline 19 & 2011 & Pitágoras & $\begin{array}{l}\text { Minha Casa } \\
\text { Minha Vida II/III }\end{array}$ & $\begin{array}{r}272 \\
\text { apartamentos }\end{array}$ & $\begin{array}{l}\text { Faixa } 2 \text { ou } 3 \text { do MCMV. Número do decreto: } \\
6.062 \text { e data: } 05 / 04 / 2011 \text {. }\end{array}$ \\
\hline 20 & 2011-13 & $\begin{array}{l}\text { Residencial } \\
\text { Vida Nova }\end{array}$ & $\begin{array}{l}\text { Minha Casa } \\
\text { Minha Vida I e } \\
\text { Prefeitura }\end{array}$ & 593 casa & $\begin{array}{l}\text { Faixa } 1 \text { do MCMV. Construtora: Enplan Eng. } \\
\text { e Construtora Ltda. Decreto de aprovação: } \\
6.024 / 2010 \text {. Área total: } 263.560,00 \mathrm{~m}^{2} \text {. }\end{array}$ \\
\hline 21 & 2012 & Patagônia & $\begin{array}{l}\text { Minha Casa } \\
\text { Minha Vida III }\end{array}$ & $\begin{array}{r}192 \\
\text { apartamentos } \\
\end{array}$ & $\begin{array}{l}\text { Faixa } 3 \text { do MCMV. Número do decreto: } \\
\text { 6.242 e data: 05/06/2012. Localiza-se em } \\
\text { ZEIS }{ }^{86} \text {. Construtora: MRV. }\end{array}$ \\
\hline 22 & $08 / 2012$ & $\begin{array}{l}\text { Cond. Spazio } \\
\text { Ponte Nova }\end{array}$ & $\begin{array}{l}\text { Minha Casa } \\
\text { Minha Vida III }\end{array}$ & $\begin{array}{r}112 \\
\text { apartamentos }\end{array}$ & $\begin{array}{l}\text { Faixa } 3 \text { do MCMV. Construtora: MRV } \\
\text { engenharia e participações S/A. }\end{array}$ \\
\hline 23 & $10 / 2012$ & $\begin{array}{l}\text { Res. Spazio } \\
\text { Poeme }\end{array}$ & MCMV III (MRV) & 56 apartamentos & $\begin{array}{l}\text { Faixa } 3 \text { do MCMV. Construtora: MRV } \\
\text { engenharia e participações S/A. }\end{array}$ \\
\hline 24 & 2013 & $\begin{array}{l}\text { Residencial } \\
\text { Pazetti }\end{array}$ & $\begin{array}{l}\text { Minha Casa } \\
\text { Minha Vida II e } \\
\text { Prefeitura } \\
\text { Municipal }\end{array}$ & 896 casas & $\begin{array}{l}\text { Faixa } 2 \text { do MCMV. A prefeitura doou a área } \\
\text { e uma empresa particular construiu. As } \\
\text { casas foram financiadas para os munícipes } \\
\text { pelo MCMV. Decreto } 6.129 / 2011 \text {. Área } \\
\text { total: } 524.690,24 \mathrm{~m}^{2} \text {. }\end{array}$ \\
\hline \multicolumn{4}{|c|}{$\begin{array}{l}\text { Total de Unidades Habitacionais } \\
\text { produzidas }\end{array}$} & 8.658 & \\
\hline \multirow{2}{*}{\multicolumn{4}{|c|}{\begin{tabular}{|l|} 
Total de casas produzidas \\
Total de lotes urbanizados produzidos \\
\end{tabular}}} & 7.399 & \\
\hline & & & & 451 & \\
\hline \multicolumn{4}{|c|}{ Total de apartamentos produzidos } & 808 & \\
\hline
\end{tabular}

\footnotetext{
${ }^{86}$ Como discutido no Capítulo II, o município de Paulínia não institui ZEIS em seu plano diretor, mas por meio de Lei de Uso do Solo (LC 54/2012). Dessa forma, o município não consta no Quadro 1 (p. 42), que apresenta os municípios que produziram HIS a partir de ZEIS instituídas nos planos diretores.
} 
Tabela 20 - Dados das Habitações de Interesse Social produzidas em Pedreira ${ }^{87}$ (1964-2014)

\begin{tabular}{|c|c|c|c|c|c|}
\hline \multicolumn{6}{|c|}{ Produção Habitacional de Pedreira } \\
\hline & $\begin{array}{l}\text { Ano de } \\
\text { entrega }\end{array}$ & Nome do Conjunto & $\begin{array}{c}\text { Agente financeiro } \\
\text { / Parcerias }\end{array}$ & $\begin{array}{c}\text { No de Unidades } \\
\text { Habitacionais }\end{array}$ & Observações \\
\hline 01 & 1969 & Vila Monte Alegre & COHAB Bandeirante & 200 casas & \\
\hline 02 & 1977 & Jardim Santa Clara & COHAB Bandeirante & 85 casas & \\
\hline 03 & $04 / 1978$ & Jardim Triunfo Maia & COHAB Bandeirante & 104 casas & \\
\hline 04. & 21/01/1982 & Jardim São Nilo & CDHU & 115 casas & \\
\hline 05 & 02/1985 & Vale Verde I & COHAB Bandeirante & 96 apartamentos & \\
\hline 06 & 1989 & Vale Verde II & COHAB Bandeirante & 112 apartamentos & \\
\hline 07 & $30 / 12 / 1993$ & Rainha da Paz I & $\mathrm{CDHU}$ & 200 casas & \\
\hline 08 & $31 / 08 / 1994$ & $\begin{array}{l}\text { Oswaldo T. } \\
\text { Magalhães I }\end{array}$ & $\mathrm{CDHU}$ & 180 casas & \\
\hline 09 & 30/06/1997 & Rainha da Paz II & $\mathrm{CDHU}$ & 56 casas & \\
\hline 10 & 05/05/1998 & Marcilio Moratori & $\mathrm{CDHU}$ & 160 apartamentos & \\
\hline 11 & $05 / 05 / 1998$ & \begin{tabular}{|l|} 
Aparecida Inês \\
Cecconelo Camiloti/ \\
Pedreira F1
\end{tabular} & $\mathrm{CDHU}$ & 85 casas & \\
\hline 12 & 05/05/1998 & Shigueo Kobayashi I & $\mathrm{CDHU}$ & 149 casas & \\
\hline 13 & $07 / 2000$ & $\begin{array}{l}\text { Santo Antônio } \\
\text { (Jardim Andrade) }\end{array}$ & COHAB Bandeirante & 80 apartamentos & \\
\hline 4 & 2002 & $\begin{array}{l}\text { Parque dos } \\
\text { Jequetibás }\end{array}$ & $\begin{array}{l}\text { Prefeitura Municipal } \\
\text { de Pedreira }\end{array}$ & $\begin{array}{l}70 \text { lotes } \\
\text { urbanizados }\end{array}$ & $\begin{array}{l}\text { Projeto de financiamento } \\
\text { da prefeitura para famílias } \\
\text { de baixa renda. Lotes a } \\
\text { baixo custo foram } \\
\text { financiados e plantas foram } \\
\text { doadas às famílias. } \\
\end{array}$ \\
\hline 15 & 05/04/2010 & Jardim Marajoara & $\mathrm{CDHU}$ & 17 casas & \\
\hline 16 & $01 / 04 / 2012$ & Shigueo Kobayashi II & $\mathrm{CDHU}$ & 14 casas & \\
\hline 17 & $02 / 05 / 2014$ & Luiz Bróglio Sobrinho & $\mathrm{CDHU}$ & 112 apartamentos & \\
\hline 18 & -- & Projeto Reviver & & 19 casas & As casas são cedidas \\
\hline 19 & -- & Projeto Esperança & & 08 casas & temporariamente para \\
\hline 20 & -- & Rua Santo Gasparini & Prefeitura Municipal & 08 casas & famílias (mais informações \\
\hline 21 & -- & Rua Sálvio Steula & de Pedreira - & 04 casas & no item "Casas em \\
\hline 2 & -- & Rua José Rabetti & $\begin{array}{l}\text { CASAS EM } \\
\text { COMODATO }\end{array}$ & 12 casas & $\begin{array}{l}\text { Comodato | município de } \\
\text { Pedreira", p. 114). } \\
\text { Essas casas NÃO FORAM } \\
\text { MAPEADAS. }\end{array}$ \\
\hline 3 & $09 / 2012$ & $\begin{array}{l}\text { Residencial Águas de } \\
\text { Março - fase I e II }\end{array}$ & $\begin{array}{l}\text { Minha casa minha } \\
\text { vida II / III }\end{array}$ & 271 casas & $\begin{array}{l}\text { São } 82 \text { casas da primeira } \\
\text { fase (faixa } 2 \text { do MCMV) e } \\
189 \text { casas (faixa } 3 \text { ) da II } \\
\text { fase. Construtora: HM } 16 \\
\text { empreendimento imobiliário } \\
\text { SPE LTDA. }\end{array}$ \\
\hline & Total de Ur & nidades Habitaciona & ais produzidas & 2.157 & \\
\hline & Total de cas & sas produzidas & & 1.527 & \\
\hline & Total de lote & es urbanizados produzi & zidos & 70 & \\
\hline & Total de apa & artamentos produzidos & & 560 & \\
\hline
\end{tabular}

${ }^{87}$ Em julho de 2015, foram entregues 125 apartamentos do Novo Mundo Residencial, faixa 3 do MCMV, entretanto, este não consta na tabela por estar fora do recorte temporal. 
Tabela 21 - Dados das Habitações de Interesse Social produzidas em Santa Bárbara d'Oeste $(1964-2014)^{88}$

\begin{tabular}{|c|c|c|c|c|c|}
\hline \multicolumn{6}{|c|}{ Produção Habitacional de Santa Bárbara d'Oeste } \\
\hline & $\begin{array}{l}\text { Ano de } \\
\text { entrega }\end{array}$ & $\begin{array}{l}\text { Nome do } \\
\text { Conjunto }\end{array}$ & $\begin{array}{l}\text { Agente } \\
\text { financeiro } \\
\text { / Parcerias }\end{array}$ & $\begin{array}{c}\text { No de } \\
\text { Unidades } \\
\text { Habitacionais }\end{array}$ & Observações \\
\hline 01 & 1970 & $\begin{array}{l}\text { Núcleo Hab. } \\
\text { Siqueira } \\
\text { Campos }\end{array}$ & $\begin{array}{l}\text { COHAB } \\
\text { Campinas }\end{array}$ & 108 casas & $\begin{array}{l}\text { Foram } 108 \text { Unidades de } 42 \mathrm{~m}^{2} \text { com } 2 \\
\text { dormitórios e } 36 \text { unidades de } 50 \mathrm{~m}^{2} \text { com } 3 \\
\text { dormitórios. }\end{array}$ \\
\hline 02 & 1975 & $\begin{array}{l}\text { Vila Santa } \\
\text { Terezinha }\end{array}$ & $\begin{array}{l}\text { COHAB } \\
\text { Campinas }\end{array}$ & 129 casas & $\begin{array}{l}\text { Foram } 129 \text { unidades de } 3 \text { dormitórios e } 58 \\
\text { unidades de } 2 \text { dormitórios. }\end{array}$ \\
\hline 03 & 1980 & $\begin{array}{l}\text { Jardim Santa } \\
\text { Rita de Cássia }\end{array}$ & $\begin{array}{l}\text { INOCOOP e } \\
\text { iniciativa }^{\text {privada }^{89}}\end{array}$ & 312 casas & $\begin{array}{l}\text { Unidades construídas em } 06 \text { quadras do } \\
\text { loteamento. Lotes menores de } 175 \mathrm{~m}^{2} \mathrm{e} \\
\text { unidades de } 46,15 \mathrm{~m}^{2} \text { com } 2 \text { dormitórios. As } \\
\text { HIS foram produzidas pela iniciativa } \\
\text { privada, a partir de cooperativa (INOCOOP), } \\
\text { com recursos públicos. }\end{array}$ \\
\hline 04 & 1983 & $\begin{array}{l}\text { Conjunto } \\
\text { Habitacional } 31 \\
\text { de Março }\end{array}$ & $\begin{array}{l}\text { COHAB } \\
\text { Campinas (em } \\
\text { duas fases) }\end{array}$ & 760 casas & $\begin{array}{l}\text { Primeira fase: } 186 \text { unidades de } 33 \mathrm{~m}^{2} \mathrm{com} \\
1 \text { dormitório e } 209 \text { unidades de } 43,91 \mathrm{~m}^{2} \\
\text { com } 2 \text { dormitórios. } \\
\text { Segunda fase: } 173 \text { unidades de } 33 \mathrm{~m}^{2} \mathrm{com} \\
1 \text { dormitório e } 192 \text { unidades de } 43,91 \mathrm{~m}^{2} \\
\text { com } 2 \text { dormitórios. }\end{array}$ \\
\hline 05 & 1985 & $\begin{array}{l}\text { Loteamento } \\
\text { Planalto do Sol }\end{array}$ & \begin{tabular}{l|} 
Prefeitura \\
Municipal de \\
Santa Bárbara
\end{tabular} & 22 casas & $\begin{array}{l}\text { Construção em área institucional do } \\
\text { loteamento (quadra 44). Unidades de 46,5 } \\
\mathrm{m}^{2} \text { com } 2 \text { dormitórios. }\end{array}$ \\
\hline 06 & 1989 & $\begin{array}{l}\text { Jardim São } \\
\text { Fernando II e } \\
\text { III }\end{array}$ & $\begin{array}{l}\text { Prefeitura } \\
\text { Municipal de } \\
\text { Santa Bárbara }\end{array}$ & $\begin{array}{l}186 \text { lotes } \\
\text { urbanizados }\end{array}$ & $\begin{array}{l}\text { Em 1989, o município implantou o } \\
\text { loteamento (lotes de } 160 \mathrm{~m}^{2} \text { ) e construiu } \\
\text { um centro comunitário, enquanto as casas } \\
\text { foram construídas em mutirão, com blocos } \\
\text { fabricados pela população em uma usina } \\
\text { provida pelo município no próprio local. Em } \\
2007 \text {, ocorreu a regularização fundiária. }\end{array}$ \\
\hline 07 & 1990 & $\begin{array}{l}\text { Conjunto Hab. } \\
\text { dos } \\
\text { Trabalhadores }\end{array}$ & $\begin{array}{l}\text { CEF e iniciativa } \\
\text { privada }\end{array}$ & 1.000 casas & $\begin{array}{l}\text { Programa de Moradia Popular da CEF em } \\
\text { parceria com empresa privada (Via } \\
\text { Engenharia). Foram } 1.000 \text { unidades } \\
\text { embriões de } 26,18 \mathrm{~m}^{2} \text { com } 1 \text { dormitório. }\end{array}$ \\
\hline 08 & 1990 & $\begin{array}{l}\text { Núcleo Hab. } \\
\text { Pref. Ângelo } \\
\text { Giubina }\end{array}$ & $\begin{array}{l}\text { Cooperativa de } \\
\text { Habitação } \\
\text { CIESP/FIESP }\end{array}$ & 186 casas & $\begin{array}{l}\text { Foram } 186 \text { unidades de } 40,07 \mathrm{~m}^{2} \text { com dois } \\
\text { dormitórios. }\end{array}$ \\
\hline 09 & 1990 & $\begin{array}{l}\text { Conjunto } \\
\text { Habitacional } \\
\text { Roberto } \\
\text { Romano }\end{array}$ & CDHU & $\begin{array}{l}1.408 \\
\text { apartamentos e } \\
206 \text { casas }\end{array}$ & $\begin{array}{l}\text { Foram } 1.408 \text { apartamentos de } 46,90 \mathrm{~m}^{2} \text {, em } \\
88 \text { edifícios de } 4 \text { pavimentos cada. } 206 \\
\text { casas de } 35,72 \mathrm{~m}^{2} \text { de } 1 \text { dormitório. } \\
\text { O conjunto não está regularizado (em } \\
2014 \text { ). }\end{array}$ \\
\hline
\end{tabular}

\footnotetext{
${ }^{88}$ No PLHIS (de 2010) do município de Santa Bárbara, constam dois loteamentos - Jardim Vila Rica (2003) e Jardim San Marino (2010) - como empreendimentos Habitacionais de Interesse Social. No entanto, foram retirados da tabela acima, pois os mesmos não foram produzidos a partir de programas públicos, segundo o técnico da prefeitura. Eles foram considerados HIS (no PLHIS) apenas por apresentarem lotes de $175 \mathrm{~m}^{2}$.

${ }^{89}$ Essas HIS foram produzidas pela iniciativa privada, a partir de cooperativa (INOCOOP), com recursos do governo (informações obtidas na Secretaria de Planejamento da Prefeitura de Santa Bárbara d'Oeste).
} 


\begin{tabular}{|c|c|c|c|c|c|}
\hline \multicolumn{6}{|c|}{ Produção Habitacional de Santa Bárbara d'Oeste } \\
\hline & $\begin{array}{l}\text { Ano de } \\
\text { entrega }\end{array}$ & $\begin{array}{l}\text { Nome do } \\
\text { Conjunto }\end{array}$ & $\begin{array}{c}\text { Agente } \\
\text { financeiro } \\
\text { /Parcerias }\end{array}$ & $\begin{array}{c}\text { No de } \\
\text { Unidades } \\
\text { Habitacionais }\end{array}$ & Observações \\
\hline 10 & 1999 & $\begin{array}{l}\text { Jardim Nova } \\
\text { Conquista }\end{array}$ & $\begin{array}{l}\text { Prefeitura com } \\
\text { financiamento } \\
\text { da CEF (Caixa } \\
\text { Econ. Federal) }\end{array}$ & $\begin{array}{l}538 \text { lotes } \\
\text { urbanizados }\end{array}$ & $\begin{array}{l}\text { Os lotes, destinados à remoção de favelas, } \\
\text { foram financiados pela CEF, conforme a lei } \\
2.282 / 1997 . \text { O prazo era de } 2 \text { anos para a } \\
\text { construção das unidades, mas, segundo o } \\
\text { técnico da prefeitura, ainda hoje existem } \\
\text { unidades precárias. A lei } 3.154 / 2000 \text { trata } \\
\text { do Jardim Nova Conquista } 90\end{array}$ \\
\hline 11 & 2012 & $\begin{array}{l}\text { Jardim Santa } \\
\text { Fé I }\end{array}$ & \begin{tabular}{|l} 
Prefeitura e \\
PAC (Governo \\
Federal pelo \\
Programa de \\
Aceleração do \\
Crescimento)
\end{tabular} & 112 casas & $\begin{array}{l}\text { Projeto destinado ao reassentamento de } 99 \\
\text { famílias da ocupação Zumbi dos Palmares, } \\
07 \text { famílias do Jd. Nova Conquista e } 06 \text { da } \\
\text { ocupação Represinha. O loteamento foi } \\
\text { aprovado em } 2007 \text { (algumas unidades em } \\
\text { construção em } 2014 \text { ). Recursos do governo } \\
\text { federal pelo Programa de Aceleração do } \\
\text { Crescimento. }\end{array}$ \\
\hline 12 & $09 / 2010$ & $\begin{array}{l}\text { Residencial Villa } \\
\text { das Palmeiras - } \\
\text { módulo IV }\end{array}$ & $\begin{array}{l}\text { Programa } \\
\text { - Minha Casa } \\
\text { Minha Vida III }\end{array}$ & $\begin{array}{l}24 \\
\text { apartamentos }\end{array}$ & $\begin{array}{l}\text { Faixa } 3 \text { do MCMV. Metro IV Construtora e } \\
\text { Incorporadora LTDA. }\end{array}$ \\
\hline 12 & $07 / 2011$ & $\begin{array}{l}\text { Residencial San } \\
\text { Marino I }\end{array}$ & $\begin{array}{l}\text { Programa } \\
\text { Minha Casa } \\
\text { Minha Vida III } \\
\end{array}$ & 72 casas & $\begin{array}{l}\text { Faixa } 3 \text { do MCMV. Construtora: TCK1 - } \\
\text { Sociedade de propósito específico de } \\
\text { construção LTDA. }\end{array}$ \\
\hline 13 & $06 / 2012$ & $\begin{array}{l}\text { Residencial San } \\
\text { Marino II }\end{array}$ & $\begin{array}{l}\text { Programa } \\
\text { Minha Casa } \\
\text { Minha Vida II }\end{array}$ & 72 casas & $\begin{array}{l}\text { Faixa } 2 \text { do MCMV. Construtora: TCK1 - } \\
\text { Sociedade de propósito específico de } \\
\text { construção LTDA. }\end{array}$ \\
\hline 14 & $10 / 2013$ & \begin{tabular}{|l|} 
Terras de São \\
Pedro- Pátio do \\
Engenho
\end{tabular} & $\begin{array}{l}\text { Programa } \\
\text { Minha Casa } \\
\text { Minha Vida III } \\
\end{array}$ & $\begin{array}{l}240 \\
\text { apartamentos e } \\
72 \text { casas } 91\end{array}$ & $\begin{array}{l}\text { Faixa } 3 \text { do MCMV. Construtora: CCDI } \\
\text { Barrocão Empreendimento Imobiliário SPE } \\
\text { Ltda. }\end{array}$ \\
\hline 15 & $10 / 2013$ & $\begin{array}{l}\text { Terras de São } \\
\text { Pedro - Pátio } \\
\text { do Barão } \\
\end{array}$ & $\begin{array}{l}\text { Programa } \\
\text { Minha Casa } \\
\text { Minha Vida III } \\
\end{array}$ & $\begin{array}{l}288 \\
\text { apartamentos e } \\
164 \text { casas }^{91}\end{array}$ & $\begin{array}{l}\text { Faixa } 3 \text { do MCMV. Construtora: CCDI } \\
\text { Barrocão Empreendimento Imobiliário SPE } \\
\text { LTDA. }\end{array}$ \\
\hline 16 & $\begin{array}{c}02 / 2014 \\
- \\
10 / 2014\end{array}$ & \begin{tabular}{|l} 
Residencial \\
Parque Real - \\
módulo I e II
\end{tabular} & $\begin{array}{l}\text { Programa } \\
\text { Minha Casa } \\
\text { Minha Vida II }\end{array}$ & $\begin{array}{l}256 \\
\text { apartamentos }\end{array}$ & Faixa 2 do MCMV. Construtora: SEGA Ltda. \\
\hline \multicolumn{4}{|c|}{$\begin{array}{l}\text { Total de Unidades Habitacionais } \\
\text { produzidas }\end{array}$} & 6.155 & \\
\hline \multicolumn{4}{|c|}{ Total de casas produzidas } & 3.215 & \\
\hline \multicolumn{4}{|c|}{ Total de lotes urbanizados produzidos } & 724 & \\
\hline \multicolumn{4}{|c|}{ Total de apartamentos produzidos } & 2.216 & \\
\hline
\end{tabular}

\footnotetext{
${ }^{90}$ Entre outras determinações, a Lei 3.154/2000 estabelece as condições para aquisição de lotes urbanizados no Jd. Nova Conquista: morar em favela em Santa Bárbara, estar inscrito no departamento de Promoção Social e estar inscrito no programa habitacional com os devidos requisitos - número de filhos, idade do titular, renda per capita, existência de membros com deficiência.

${ }^{91}$ A quantidade específica de apartamentos e casas foi obtida a partir da leitura da foto aérea e da observação da vista por meio do street view, pois a informação fornecida foi o número total de unidades.
} 
Tabela 22 - Dados das Habitações de Interesse Social produzidas em Santo Antônio de Posse (1964-2014)

\begin{tabular}{|c|c|c|c|c|c|}
\hline \multicolumn{6}{|c|}{ Produção Habitacional de Santo Antônio de Posse } \\
\hline & $\begin{array}{l}\text { Ano de } \\
\text { entrega }\end{array}$ & $\begin{array}{l}\text { Nome do } \\
\text { Conjunto }\end{array}$ & $\begin{array}{c}\text { Agente } \\
\text { financeiro } \\
\text { /Parcerias }\end{array}$ & $\begin{array}{c}\mathrm{N}^{0} \text { de } \\
\text { Unidades } \\
\text { Habitacionais }\end{array}$ & Observações \\
\hline & 1988 & $\begin{array}{l}\text { Novo } \\
\text { Horizonte } 1\end{array}$ & \begin{tabular}{|l|} 
Prefeitura de \\
Santo Antônio \\
de Posse
\end{tabular} & 94 lotes & \multirow{2}{*}{$\begin{array}{l}\text { A Lei no } 1.162 \text { de } 1988 \text { regulamenta a "doação } \\
\text { para direito real de uso de terrenos } \\
\text { municipais". Conforme informação da } \\
\text { prefeitura, em } 2014 \text { está sendo regularizada a } \\
\text { propriedade dos lotes por meio do Programa } \\
\text { Estadual Cidade Legal. }\end{array}$} \\
\hline 2 & 1988 & $\begin{array}{l}\text { Novo } \\
\text { Horizonte } 2\end{array}$ & $\begin{array}{l}\text { Prefeitura de } \\
\text { Santo Antônio } \\
\text { de Posse }\end{array}$ & 31 lotes & \\
\hline & $01 / 1992$ & \begin{tabular}{|l|} 
Prefeito \\
Augusto Lala \\
\end{tabular} & $\mathrm{CDHU}$ & 116 casas & \multirow{2}{*}{$\begin{array}{l}\text { Os lotes possuem área de } 200 \mathrm{~m}^{2} \text {, com casas } \\
\text { de } 35,72 \mathrm{~m}^{2} \text {. Infraestrutura urbana: água, } \\
\text { esgoto, galerias pluviais, guias e asfalto. A } \\
\text { regularização fundiária está pendente (em } \\
\text { 2015). }\end{array}$} \\
\hline & $10 / 1996$ & $\begin{array}{l}\text { Jardim das } \\
\text { Flores }\end{array}$ & $\mathrm{CDHU}$ & 100 casas & \\
\hline 25 & 1996 & Bela Vista I & \multirow[b]{2}{*}{$\begin{array}{l}\text { Prefeitura de } \\
\text { Santo Antônio } \\
\text { de Posse }\end{array}$} & 107 lotes & \multirow{2}{*}{$\begin{array}{l}\text { A infraestrutura urbana completa do Bela Vista } \\
\text { I e II foi concluída apenas em 2013: água, } \\
\text { esgoto, galerias pluviais, guias e asfalto. Lotes } \\
\text { foram doados pela prefeitura (obs.: realizado } \\
\text { sem infraestrutura e em área muito íngreme). }\end{array}$} \\
\hline 06 & 2000 & Bela Vista II & & 616 lotes & \\
\hline & 2014 & $\begin{array}{l}\text { Condomínio } \\
\text { Azaleia }\end{array}$ & MCMV III & $\begin{array}{l}28 \text { casas } \\
\text { sobrepostas }\end{array}$ & $\begin{array}{l}\text { Faixa } 3 \text { do MCMV. Foram entregues } 28 \text { casas } \\
\text { sobrepostas, mas existe uma quantidade maior } \\
\text { contratada, conforme informação obtida por } \\
\text { meio de contato com técnico da prefeitura. }\end{array}$ \\
\hline \multicolumn{4}{|c|}{$\begin{array}{l}\text { Total de Unidades Habitacionais } \\
\text { produzidas }\end{array}$} & \multicolumn{2}{|r|}{ 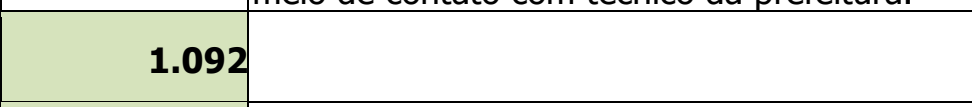 } \\
\hline \multicolumn{4}{|c|}{ Total de casas produzidas } & \multicolumn{2}{|l|}{244} \\
\hline \multicolumn{4}{|c|}{ Total de lotes urbanizados produzidos } & \multicolumn{2}{|l|}{848} \\
\hline \multicolumn{4}{|c|}{ Total de apartamentos produzidos } & \multicolumn{2}{|l|}{0} \\
\hline
\end{tabular}

Tabela 23 - Dados das Habitações de Interesse Social produzidas em Sumaré (1964-2014)

\begin{tabular}{|c|c|c|c|c|}
\hline \multicolumn{5}{|c|}{ Produção Habitacional de Sumaré ${ }^{92}$} \\
\hline $\begin{array}{l}\text { Ano de } \\
\text { entrega }\end{array}$ & $\begin{array}{l}\text { Nome do } \\
\text { Conjunto }\end{array}$ & $\begin{array}{c}\text { Agente financeiro } \\
\text { / Parcerias }\end{array}$ & $\begin{array}{c}\text { No de Unidades } \\
\text { Habitacionais }\end{array}$ & Observações \\
\hline 1977 & $\begin{array}{l}\text { Vila Yolanda/Costa e } \\
\text { Silva }\end{array}$ & COHAB Campinas & 356 casas & \\
\hline 1979 & $\begin{array}{l}\text { Núcleo CECAP - Pq. } \\
\text { Ver. Euclides } \\
\text { Miranda }\end{array}$ & CECAP & 235 casas & $\begin{array}{l}\text { CECAP (Companhia Estadual } \\
\text { de Casas Populares) - primeiro } \\
\text { nome da empresa CDHU. }\end{array}$ \\
\hline 1980 & $\begin{array}{l}\text { Parque Nova Veneza } \\
\text { - INOCOOP }\end{array}$ & $\begin{array}{l}\text { Cooperativa } \\
\text { Habitacional Nova } \\
\text { Veneza }\end{array}$ & 415 casas & \\
\hline 1982 & $\begin{array}{l}\text { Conj. Habit. Dona } \\
\text { Zilda Gamba Natel }\end{array}$ & COHAB Campinas & 342 casas & \\
\hline
\end{tabular}

\footnotetext{
92 Ao realizar o levantamento, tomou-se conhecimento de quatro conjuntos Habitacionais de Interesse Social Aurea (193 casas), Vivenda (166 casas), Verano (200 apartamentos) e Explendido (200 apartamentos) -, que não constam da tabela por estarem fora do recorte temporal.
} 


\begin{tabular}{|c|c|c|c|c|c|}
\hline \multicolumn{6}{|c|}{ Produção Habitacional de Sumaré ${ }^{92}$} \\
\hline & $\begin{array}{l}\text { Ano de } \\
\text { entrega }\end{array}$ & $\begin{array}{l}\text { Nome do } \\
\text { Conjunto }\end{array}$ & $\begin{array}{c}\text { Agente financeiro } \\
\text { / Parcerias }\end{array}$ & $\begin{array}{c}\text { No de Unidades } \\
\text { Habitacionais }\end{array}$ & Observações \\
\hline 05 & 1982 & Jardim João Paulo II & $\begin{array}{l}\mathrm{COHAB} \\
\text { Bandeirantes }\end{array}$ & 948 casas & \\
\hline 06 & 1998 & $\begin{array}{l}\text { Conj Hab. Angelo } \\
\text { Tomazin }\end{array}$ & $\mathrm{CDHU}$ & 500 casas & \\
\hline 07 & 2004 & $\begin{array}{l}\text { Residencial Pq dos } \\
\text { Sabiás - condomínio } \\
\text { B }\end{array}$ & $\begin{array}{l}\text { Minha casa Minha } \\
\text { Vida II }\end{array}$ & 32 apartamentos & $\begin{array}{l}\text { Faixa } 2 \text { do MCMV. Construtora: } \\
\text { Empreendimentos Imobiliários } \\
\text { Ltda. }\end{array}$ \\
\hline 08 & $06 / 2007$ & $\begin{array}{l}\text { Cond. Residencial } \\
\text { Califórnia }\end{array}$ & PAR & 192 apartamentos & $\begin{array}{l}\text { PAR: Programa de } \\
\text { Arrendamento Residencial }\end{array}$ \\
\hline 09 & $02 / 2008$ & $\begin{array}{l}\text { Residencial Jd. } \\
\text { Sumaré }\end{array}$ & PAR & 234 casas & $\begin{array}{l}\text { PAR: Programa de } \\
\text { Arrendamento Residencial }\end{array}$ \\
\hline 10 & 2008 & $\begin{array}{l}\text { Res. Recanto das } \\
\text { Árvores (área Cura) }\end{array}$ & COHAB & 75 casas & \\
\hline 11 & 2008 & $\begin{array}{l}\text { Res. Recanto das } \\
\text { Árvores (área Cura) }\end{array}$ & COHAB & 320 apartamentos & \\
\hline 12 & $01 / 2009$ & $\begin{array}{l}\text { Residencial Jd. } \\
\text { Sumaré II }\end{array}$ & PAR & 253 casas & $\begin{array}{l}\text { PAR: Programa de } \\
\text { Arrendamento Residencial }\end{array}$ \\
\hline 13 & $\begin{array}{l}2010- \\
2012\end{array}$ & $\begin{array}{l}\text { Construção de } \\
\text { Unidades } \\
\text { Habitacionais }\end{array}$ & COHAB Campinas & 58 casas & $\begin{array}{l}\text { NÃO MAPEADAS, por essas } \\
\text { unidades habitacionais não } \\
\text { constituírem uma mancha } \\
\text { contínua. Elas estão em } \\
\text { diversas áreas da cidade. }\end{array}$ \\
\hline 14 & $05 / 2011$ & $\begin{array}{l}\text { Jardim Dall Orto } \\
\text { terceira parte- } \\
\text { segunda etapa }\end{array}$ & $\begin{array}{l}\text { Minha Casa Minha } \\
\text { Vida III }\end{array}$ & 330 casas & $\begin{array}{l}\text { Faixa } 3 \text { do MCMV. Construtora: } \\
\text { Jardim Dall Orto } \\
\text { empreendimento imobiliário } \\
\text { SPE LTDA. }\end{array}$ \\
\hline 15 & $05 / 2011$ & $\begin{array}{l}\text { Araucária } \\
\text { Condomínio Clube }\end{array}$ & MCMV II & 320 apartamentos & $\begin{array}{l}\text { Faixa } 2 \text { do MCMV. Construtora: } \\
\text { Sumaré Bom Retiro } \\
\text { empreendimento imobiliários } \\
\text { SPE LTDA. }\end{array}$ \\
\hline 16 & $\begin{array}{l}2011- \\
2012\end{array}$ & $\begin{array}{l}\text { Parque Sevilha - } \\
\text { Maria Antonia }\end{array}$ & $\begin{array}{l}\text { FNHIS } 2008 \text { / } \\
\text { MCIDADES/CEF }\end{array}$ & 6 casas & NÃO MAPEADAS (metodologia) \\
\hline 17 & $\begin{array}{l}2011- \\
2012\end{array}$ & $\begin{array}{l}\text { Residencial Portal } \\
\text { Bordon - Picerno }\end{array}$ & $\begin{array}{l}\text { FNHIS } 2007 \text { e 2008/ } \\
\text { MCIDADES/ CEF }\end{array}$ & 135 casas & $\begin{array}{l}\text { Foram } 63 \text { casas (FNHIS 2007) } \\
\text { e } 72 \text { casas (FNHIS 2008). }\end{array}$ \\
\hline 18 & $03 / 2012$ & Bela Vista Varandas & $\begin{array}{l}\text { Minha Casa Minha } \\
\text { Vida II }\end{array}$ & 544 apartamentos & $\begin{array}{l}\text { Faixa } 2 \text { do MCMV. Construtora: } \\
\text { Sumaré Matão } \\
\text { empreendimento imobiliário } \\
\text { SPE LTDA. }\end{array}$ \\
\hline 19 & $04 / 2012$ & $\begin{array}{l}\text { Condomínio } \\
\text { Residencial Sumaré } \\
\text { IV }\end{array}$ & $\begin{array}{l}\text { Minha Casa Minha } \\
\text { Vida II }\end{array}$ & 400 apartamentos & $\begin{array}{l}\text { Faixa } 2 \text { do MCMV. Construtora: } \\
\text { Recanto dos Sonhos } \\
\text { empreendimento imobiliário } \\
\text { SPE LTDA. }\end{array}$ \\
\hline 20 & 2012 & Conj. Hab. Amabile & $\begin{array}{l}\text { Minha Casa Minha } \\
\text { Vida II }\end{array}$ & 184 casas & Faixa 2 do MCMV. \\
\hline 21 & 2012 & $\begin{array}{l}\text { Conj. Habitacional } \\
\text { Nobile }\end{array}$ & $\begin{array}{l}\text { Minha Casa Minha } \\
\text { Vida II } \\
\end{array}$ & 192 apartamentos & Faixa 2 do MCMV. \\
\hline & $01 / 2013$ & $\begin{array}{l}\text { Condomínio } \\
\text { Residencial Porto } \\
\text { Belo }\end{array}$ & $\begin{array}{l}\text { Minha Casa Minha } \\
\text { Vida III }\end{array}$ & 320 apartamentos & $\begin{array}{l}\text { Faixa } 3 \text { do MCMV. Construtora: } \\
\text { Recanto dos Sonhos } \\
\text { empreendimento imobiliário } \\
\text { SPE LTDA. }\end{array}$ \\
\hline
\end{tabular}




\begin{tabular}{|c|c|c|c|c|}
\hline \multicolumn{5}{|c|}{ Produção Habitacional de Sumaré ${ }^{92}$} \\
\hline $\begin{array}{l}\text { Ano de } \\
\text { entrega }\end{array}$ & $\begin{array}{l}\text { Nome do } \\
\text { Conjunto }\end{array}$ & $\begin{array}{c}\text { Agente financeiro } \\
\text { / Parcerias }\end{array}$ & $\begin{array}{l}\text { No de Unidades } \\
\text { Habitacionais }\end{array}$ & Observações \\
\hline 2013 & $\begin{array}{l}\text { Residencial Emílio } \\
\text { Bosco - Matão }\end{array}$ & $\begin{array}{l}\text { Minha Casa Minha } \\
\text { Vida I }\end{array}$ & 560 apartamentos & $\begin{array}{l}\text { Faixa } 1 \text { do MCMV. Cury } \\
\text { Construtora. }\end{array}$ \\
\hline $\begin{array}{l}2013- \\
2015\end{array}$ & $\begin{array}{l}\text { Jardim das } \\
\text { Estâncias - Matão }\end{array}$ & $\begin{array}{l}\text { Minha Casa Minha } \\
\text { Vida I }\end{array}$ & $\begin{array}{l}2.240 \\
\text { apartamentos }\end{array}$ & $\begin{array}{l}\text { Faixa } 1 \text { do MCMV. Cury } \\
\text { Construtora e Incorporadora. }\end{array}$ \\
\hline $\begin{array}{l}2013- \\
2015\end{array}$ & $\begin{array}{l}\text { Jardim das Águas - } \\
\text { Nova Veneza }\end{array}$ & $\begin{array}{l}\text { Minha Casa Minha } \\
\text { Vida I }\end{array}$ & $\begin{array}{l}1.500 \\
\text { apartamentos }\end{array}$ & $\begin{array}{l}\text { Faixa } 1 \text { do MCMV. Construtora: } \\
\text { Saned. }\end{array}$ \\
\hline $\begin{array}{l}2013- \\
2015\end{array}$ & $\begin{array}{l}\text { Residencial Itália - } \\
\text { área Cura }\end{array}$ & $\begin{array}{l}\text { Minha Casa Minha } \\
\text { Vida I }\end{array}$ & $\begin{array}{l}1.180 \\
\text { apartamentos }\end{array}$ & Faixa 1 do MCMV. \\
\hline $\begin{array}{l}2013- \\
2016\end{array}$ & \begin{tabular}{|l} 
Jardim das \\
Estâncias - Matão
\end{tabular} & $\begin{array}{l}\text { Minha Casa Minha } \\
\text { Vida I }\end{array}$ & 156 casas & Faixa 1 do MCMV. \\
\hline \multicolumn{3}{|c|}{ Total de Unidades Habitacionais produzidas } & \multicolumn{2}{|l|}{12.027} \\
\hline \multicolumn{3}{|c|}{ Total de casas produzidas } & \multicolumn{2}{|c|}{4.227} \\
\hline \multicolumn{3}{|c|}{ Total de lotes urbanizados produzidos } & \multicolumn{2}{|c|}{0} \\
\hline \multicolumn{3}{|c|}{ Total de apartamentos produzidos } & \multicolumn{2}{|c|}{7.800} \\
\hline
\end{tabular}

Tabela 24 - Dados das Habitações de Interesse Social produzidas em Valinhos (1964-2014)

\begin{tabular}{|c|c|c|c|c|c|}
\hline \multicolumn{6}{|c|}{ Produção Habitacional de Valinhos } \\
\hline & $\begin{array}{l}\text { Ano de } \\
\text { entrega }\end{array}$ & $\begin{array}{l}\text { Nome do } \\
\text { Conjunto }\end{array}$ & $\begin{array}{c}\text { Agente financeiro } \\
\text { /Parcerias }\end{array}$ & $\begin{array}{c}\text { No de } \\
\text { Unidades } \\
\text { Habitacionais }\end{array}$ & Observações \\
\hline 01 & $04 / 1969$ & $\begin{array}{l}\text { Vila Boa } \\
\text { Esperança }\end{array}$ & $\mathrm{COHAB}$ & 293 casas & \\
\hline 02 & $05 / 1969$ & Jd. Bom Retiro I & $\mathrm{COHAB}$ & 197 casas & \\
\hline 03 & $07 / 1976$ & \begin{tabular}{|l|} 
Jardim Novo \\
Mundo I e II
\end{tabular} & $\mathrm{COHAB}$ & 151 casas & \\
\hline 04 & $03 / 1977$ & $\begin{array}{l}\text { Jd. Bom Retiro } \\
\text { II }\end{array}$ & COHAB & 210 casas & \\
\hline 05 & 1979 & Jardim Paraíso & $\mathrm{CDHU}$ & 552 casas & \\
\hline 06 & $08 / 1979$ & $\begin{array}{l}\text { Jd. Novo Mundo } \\
\text { III }\end{array}$ & $\mathrm{COHAB}$ & 186 casas & \\
\hline 07 & 1981 & Jardim União & $\begin{array}{l}\text { Prefeitura Municipal } \\
\text { de Valinhos }\end{array}$ & 100 casas & $\begin{array}{l}\text { No terreno, de propriedade da } \\
\text { prefeitura, houve o parcelamento e a } \\
\text { cessão dos lotes, com o pagamento } \\
\text { mensal pelos benificiados. Em relação } \\
\text { às construções, o material foi cedido } \\
\text { pela prefeitura, a mão de obra ficou a } \\
\text { cargo do beneficiado e houve } \\
\text { orientação técnica da prefeitura. }\end{array}$ \\
\hline 08 & 04/1982 & Jardim Figueiras & $\mathrm{COHAB}$ & 225 casas & \\
\hline 09 & $07 / 1986$ & Jardim do Lago & COHAB & $\begin{array}{l}214 \text { casas e } \\
226 \\
\text { apartamentos }\end{array}$ & $\begin{array}{l}\text { O número total de unidades } \\
\text { habitacionais (440) foi fornecido pela } \\
\text { prefeitura, entretanto, o número de } \\
\text { apartamentos e casas é aproximado. A } \\
\text { partir da planta da prefeitura, foi } \\
\text { realizada a contagem da quantidade de } \\
\text { casas e subtraída do total, para } \\
\text { obtenção do número de apartamentos. }\end{array}$ \\
\hline
\end{tabular}




\begin{tabular}{|c|c|c|c|c|c|}
\hline \multicolumn{6}{|c|}{ Produção Habitacional de Valinhos } \\
\hline & $\begin{array}{l}\text { Ano de } \\
\text { entrega }\end{array}$ & $\begin{array}{l}\text { Nome do } \\
\text { Conjunto }\end{array}$ & $\begin{array}{c}\text { Agente financeiro } \\
\text { /Parcerias }\end{array}$ & $\begin{array}{c}\text { No de } \\
\text { Unidades } \\
\text { Habitacionais }\end{array}$ & Observações \\
\hline 10 & 1991 & $\begin{array}{l}\text { Jardim Morada } \\
\text { do Sol }\end{array}$ & $\begin{array}{l}\text { Prefeitura Municipal } \\
\text { de Valinhos }\end{array}$ & $\begin{array}{l}158 \text { lotes } \\
\text { urbanizados }\end{array}$ & $\begin{array}{l}\text { Foram financiados lotes urbanizados, } \\
\text { ocorrendo o pagamento mensal pelos } \\
\text { benificiados. As construções foram } \\
\text { realizadas pelos moradores. }\end{array}$ \\
\hline 11 & 1992 & Jd. São Marcos & $\mathrm{CDHU}$ & 903 casas & \\
\hline 12 & $07 / 1992$ & Jd. Centenário & $\mathrm{COHAB}$ & 284 casas & \\
\hline 13 & 1993 & Jd. Universo I & $\mathrm{CDHU}$ & 25 casas & Projeto Solo e Cimento. \\
\hline 14. & 1995 & Ação Solidária & $\begin{array}{l}\text { MUTIRÃO e } \\
\text { Prefeitura Municipal } \\
\text { de Valinhos }\end{array}$ & 21 casas & $\begin{array}{l}\text { A área foi financiada pela prefeitura, } \\
\text { ocorrendo pagamento mensal pelos } \\
\text { beneficiados. A prefeitura doou o } \\
\text { material para as construções. }\end{array}$ \\
\hline 15 & 1997 & Jd. Universo II & $\mathrm{CDHU}$ & $\begin{array}{l}64 \\
\text { apartamentos e } \\
186 \text { casas }\end{array}$ & \\
\hline 16 & $07 / 1999$ & $\begin{array}{l}\text { Jd. Centenário } \\
\text { II }\end{array}$ & $\mathrm{COHAB}$ & \begin{tabular}{l|}
96 \\
apartamentos
\end{tabular} & \\
\hline 17 & 2005 & & $\begin{array}{l}\text { Prefeitura Municipal } \\
\text { de Valinhos }\end{array}$ & 7 casas & $\begin{array}{l}\text { NÃO MAPEADAS (metodologia). Essas } \\
\text { sete casas foram produzidas para as } \\
\text { famílias que viviam no lixão. }\end{array}$ \\
\hline 18 & 2007 & Jardim Alvorada & PAR & $\begin{array}{l}416 \\
\text { apartamentos }\end{array}$ & \\
\hline 19 & 2010 & $\begin{array}{l}\text { Jardim Morada } \\
\text { do Sol II }\end{array}$ & $\mathrm{CDHU}$ & 18 casas & \\
\hline 20 & $06 / 2011$ & $\begin{array}{l}\text { Vila Ventura I e } \\
\text { II }\end{array}$ & $\begin{array}{l}\text { Minha Casa Minha } \\
\text { Vida II / III (CEF) }\end{array}$ & $\begin{array}{l}240 \\
\text { apartamentos }\end{array}$ & $\begin{array}{l}\text { Faixa } 2 \text { ou } 3 \text { do MCMV. Construtora: } \\
\text { São Ricardo Empreendimentos } \\
\text { Imobiliários Ltda. }\end{array}$ \\
\hline & $05 / 2012$ & Vista Valey I & $\begin{array}{l}\text { Minha Casa Minha } \\
\text { Vida III (CEF) }\end{array}$ & $\begin{array}{l}271 \\
\text { apartamentos }\end{array}$ & $\begin{array}{l}\text { Faixa } 3 \text { do MCMV. Construtora: DMO } \\
\text { Engenharia e Incorporações Ltda. }\end{array}$ \\
\hline 22 & $06 / 2012$ & Vista Valey II & $\begin{array}{l}\text { Minha Casa Minha } \\
\text { Vida II (CEF) }\end{array}$ & $\begin{array}{l}224 \\
\text { apartamentos }\end{array}$ & $\begin{array}{l}\text { Faixa } 2 \text { do MCMV. Construtora: Silver } \\
\text { Projetos Imobiliários Ltda. }\end{array}$ \\
\hline 23 & $03 / 2013$ & $\begin{array}{l}\text { Mais Campos } \\
\text { Sales }\end{array}$ & $\begin{array}{l}\text { Minha Casa Minha } \\
\text { Vida III (BANCO DO } \\
\text { BRASIL }^{93} \text { ) }\end{array}$ & $\begin{array}{l}744 \\
\text { apartamentos }\end{array}$ & $\begin{array}{l}\text { Faixa } 3 \text { do MCMV. Construtora: Living } \\
\text { Panama Empreendimentos Imobiliários } \\
\text { Ltda. }\end{array}$ \\
\hline 24. & $10 / 2013$ & \begin{tabular}{|l|} 
Bosque do \\
Frutal III \\
\end{tabular} & \begin{tabular}{|l|} 
Minha Casa Minha \\
Vida III (CEF)
\end{tabular} & $\begin{array}{l}168 \\
\text { apartamentos }\end{array}$ & $\begin{array}{l}\text { Faixa } 3 \text { do MCMV. Construtora: Frutal } \\
\text { Empreendimentos Imobiliários. }\end{array}$ \\
\hline & $12 / 2013$ & $\begin{array}{l}\text { Residencial São } \\
\text { Conrado }\end{array}$ & $\begin{array}{l}\text { Minha Casa Minha } \\
\text { Vida II (CEF) }\end{array}$ & $\begin{array}{l}192 \\
\text { apartamentos }\end{array}$ & $\begin{array}{l}\text { Faixa } 2 \text { do MCMV. Construtora: MC2 } \\
\text { Incorporadora e Construtora Ltda. }\end{array}$ \\
\hline 20 & 2013 & $\begin{array}{l}\text { Vale das } \\
\text { Figueiras }\end{array}$ & $\begin{array}{l}\text { Minha Casa Minha } \\
\text { Vida II (CEF) }\end{array}$ & $\begin{array}{l}760 \\
\text { apartamentos }\end{array}$ & Faixa 2 do MCMV. \\
\hline & 2014 & Piazza di Lucca & $\begin{array}{l}\text { Minha Casa Minha } \\
\text { Vida II (CEF) }\end{array}$ & $\begin{array}{l}30 \\
\text { apartamentos }\end{array}$ & Faixa 2 do MCMV. \\
\hline \multicolumn{4}{|c|}{$\begin{array}{l}\text { Total de Unidades Habitacionais } \\
\text { produzidas }\end{array}$} & 7.161 & \\
\hline \multicolumn{4}{|c|}{ Total de casas produzidas } & 3.572 & \\
\hline \multicolumn{4}{|c|}{ Total de lotes urbanizados produzidos } & 158 & \\
\hline \multicolumn{4}{|c|}{ Total de apartamentos produzidos } & 3.431 & \\
\hline
\end{tabular}

${ }^{93}$ A informação sobre a data de entrega do empreendimento não foi obtida no Banco do Brasil, mas na Prefeitura Municipal de Valinhos (Diretoria de Habitação). 
Tabela 25 - Dados das Habitações de Interesse Social produzidas em Vinhedo (1964-2014)

\begin{tabular}{|c|c|c|c|c|c|}
\hline \multicolumn{6}{|c|}{ Produção Habitacional de Vinhedo } \\
\hline & $\begin{array}{l}\text { Ano de } \\
\text { entrega }\end{array}$ & $\begin{array}{l}\text { Nome do } \\
\text { Conjunto }\end{array}$ & $\begin{array}{c}\text { Agente financeiro } \\
\text { / Parcerias }\end{array}$ & $\begin{array}{c}\text { No de Unidades } \\
\text { Habitacionais }\end{array}$ & Observações \\
\hline b1 & 1968 & Vila João XXIII & Cohab Bandeirantes 1 & 102 casas & \\
\hline 2 & 1980 & Jd. III Irmãos & Cohab Bandeirantes 1 & 101 casas & \multirow{3}{*}{$\begin{array}{l}\text { Esse Programa foi realizado pela } \\
\text { Caixa Econômica Estadual. }\end{array}$} \\
\hline 03 & 1982 & Jd. Bela Vista & \multirow{2}{*}{$\begin{array}{l}\text { Programa Nosso } \\
\text { Teto Nossa Caixa }\end{array}$} & 228 casas & \\
\hline 04 & 1988 & Jd. Bela Vista & & 36 casas & \\
\hline & 1988 & $\begin{array}{l}\text { Jardim Nova } \\
\text { Canudos }\end{array}$ & $\begin{array}{l}\text { Associação Sem } \\
\text { Casa e Prefeitura } \\
\text { Municipal de } \\
\text { Vinhedo }\end{array}$ & 246 lotes urbanizados & $\begin{array}{l}\text { A prefeitura comprou a área em } \\
\text { parceria com a Associação, que, } \\
\text { juntamente com seus inscritos, } \\
\text { aprovou o projeto e sorteou } \\
\text { entre os associados. A prefeitura } \\
\text { fez o financiamento para os } \\
\text { mutuários e fez os contratos. O } \\
\text { parcelamento ocorreu em } 1988, \\
\text { e as casas foram construídas nas } \\
\text { décadas de } 1980 \text { e } 1990 \text {. }\end{array}$ \\
\hline 06 & 1990 & Bela Vista & $\mathrm{CDHU}$ & 150 casas & Casas com $36 \mathrm{~m}^{2}$. \\
\hline 7 & 1990 & \begin{tabular}{|l|l|} 
Jardim Von \\
Zuben
\end{tabular} & \begin{tabular}{|l} 
Programa Nosso \\
Teto (Estadual)
\end{tabular} & 463 casas & $\begin{array}{l}\text { Casas com } 24 \mathrm{~m}^{2} \text {. Realizado } \\
\text { pela Caixa Econômica Estadual. }\end{array}$ \\
\hline 08 & 1994 & Jardim Eldorado & \multirow{3}{*}{$\begin{array}{l}\text { Prefeitura Municipal } \\
\text { de Vinhedo }\end{array}$} & 168 lotes urbanizados & \multirow{3}{*}{$\begin{array}{l}\text { A prefeitura comprou a área e } \\
\text { fez o financiamento para os } \\
\text { mutuários (não houve doação). }\end{array}$} \\
\hline 09 & 1996 & Bela Vista II & & 100 lotes urbanizados $f$ & \\
\hline 10 & 1996 & São Thomé & & 100 lotes urbanizados & \\
\hline 1 & 2000 & $\begin{array}{l}\text { Vila Junqueira/ } \\
\text { Mário Covas }\end{array}$ & $\mathrm{CDHU}$ & 192 apartamentos & \\
\hline 12 & 2000 & Vida Nova I & \multirow{3}{*}{$\begin{array}{l}\text { Iniciativa Privada e } \\
\text { Prefeitura Municipal } \\
\text { de Vinhedo }\end{array}$} & 532 lotes urbanizados & \multirow{3}{*}{$\begin{array}{l}\text { A iniciativa privada (Sol Vinhedo } \\
\text { realizou o parcelamento. A } \\
\text { contribuição da prefeitura foi o } \\
\text { cadastro e a doação de plantas. }\end{array}$} \\
\hline 13 & 2004 & Vida Nova II & & 178 lotes urbanizados & \\
\hline 4 & 2004 & Vida Nova III & & 425 lotes urbanizados & \\
\hline 5 & 2004 & $\begin{array}{l}\text { Capela /São } \\
\text { Sebastião Roque } \\
\text { dos Reis }\end{array}$ & $\mathrm{CDHU}$ & 192 apartamentos & \\
\hline 6 & 2009 & São Thomé & \begin{tabular}{|l|} 
Prefeitura Municipal \\
de Vinhedo e Caixa \\
Econômica Federal
\end{tabular} & 37 casas & $\begin{array}{l}\text { A prefeitura comprou a área e } \\
\text { executou as obras, e o } \\
\text { financiamento foi feito pela CEF. }\end{array}$ \\
\hline 7 & $09 / 2010$ & $\begin{array}{l}\text { Residencial Sol } \\
\text { Maior }\end{array}$ & $\begin{array}{l}\text { Minha Casa Minha } \\
\text { Vida III }\end{array}$ & 16 apartamentos & $\begin{array}{l}\text { Faixa } 3 \text { do MCMV. Construtora: } \\
\text { Cortiz Consultoria e Construção } \\
\text { de Imovéis. }\end{array}$ \\
\hline 8 & 2012 & $\begin{array}{l}\text { Portal da } \\
\text { Esperança I e II }\end{array}$ & $\begin{array}{l}\text { Minha Casa Minha } \\
\text { Vida I }\end{array}$ & $\begin{array}{l}256 \text { apartamentos e } 8 \mathrm{~F} \\
\text { casas }\end{array}$ & $\begin{array}{l}\text { Faixa } 1 \text { do MCMV. Totalizam } 264 \\
\text { unidades. }\end{array}$ \\
\hline 9 & 2013 & $\begin{array}{l}\text { Núcleo Hab. Ma. } \\
\text { Helena B. } \\
\text { Soldeira } \\
\text { /Vinhedo F } \\
\end{array}$ & $\mathrm{CDHU}$ & 93 apartamentos & \\
\hline \multicolumn{4}{|c|}{$\begin{array}{l}\text { Total de Unidades Habitacionais } \\
\text { produzidas }\end{array}$} & 3.623 & \\
\hline \multicolumn{4}{|c|}{ Total de casas produzidas } & 1.125 & \\
\hline \multicolumn{4}{|c|}{ Total de lotes urbanizados produzidos } & 1.749 & \\
\hline \multicolumn{4}{|c|}{ Total de apartamentos produzidos } & 749 & \\
\hline
\end{tabular}

Fontes da Tabela 6 à Tabela 25: os dados foram fornecidos pelos técnicos de cada município. Em alguns casos, foram utilizados também dados da CDHU, da Caixa Econômica Federal, da COHAB Campinas e da Pesquisa (FERRAMENTAS [...], 2014). Esses dados foram sistematizados pela autora. 


\subsection{Casos especiais de produções de Habitação de Interesse Social na RMC}

A seguir, apresentam-se três casos de produção de Habitação de Interesse Social (HIS) não convencionais: o primeiro em Pedreira, de casas cedidas em comodato; o segundo em Americana, onde o poder público desapropriou áreas particulares para realizar HIS e ressarciu os proprietários, por meio de lotes parcelados e com infraestrutura, que são vendidos por esse proprietário como HIS; e o terceiro em Campinas, onde foram vendidas casas em processo de construção pela COHAB Campinas. Assim como os outros conjuntos de habitação de interesse social pesquisados, esses três foram levantados em 2013 e 2014, com alguns telefonemas para confirmação de informações em 2015 e em janeiro de 2016.

Cabe lembrar que esses casos foram levantados após várias entrevistas com técnicos municipais, pois, quando se tentava compreender como esses conjuntos tinham sido realizados ou quais tinham sido os papéis de cada um dos agentes no desenvolvimento do projeto, foi possível perceber algumas peculiaridades nas formas de produção desses conjuntos. Para que seja possível compreender melhor essas especificidades, decidiu-se apresentá-los separadamente, conforme seguem:

\subsubsection{Casas em Comodato | município de Pedreira}

No município de Pedreira, a prefeitura construiu, em terrenos de sua propriedade, 51 casas, as quais são cedidas, por meio de um contrato de concessão de uso, para famílias que necessitam de habitações e não possuem condições de adquiri-las por meio de outros programas.

Por volta de 1996, o conjunto de casas denominado "Reviver", com 19 casas, foi o primeiro a ser construído e abrigava famílias carentes que foram removidas de uma pequena favela que havia no município. Na sequência, os outros conjuntos de casas foram construídos no município (ver itens 18 a 20 da Tabela 20, p. 106) e o órgão que realizou o procedimento burocrático e a seleção das famílias foi o SOS - Serviço de Obras Sociais de Pedreira, uma instituição administrada pela primeira dama.

Foram realizados contratos com duração de vinte anos e, conforme dados da Secretaria de Promoção Social do município, em 2016 ocorrerá o vencimento do contrato dessas famílias. Durante esse período, elas apresentaram dificuldades de compreender que podiam usufruir da habitação, mas que a propriedade pertencia à prefeitura. Foi relatado pela Secretaria de Promoção Social do município que diversas famílias venderam as 
habitações, outras as alugaram. Outro problema recorrente tem sido a falta de manutenção das habitações, embora haja casas bem conservadas.

A Secretaria de Promoção Social revelou, ainda, que os contratos serão renovados, entretanto, por um período menor de tempo, para que possa haver um melhor monitoramento das famílias. O objetivo da prefeitura é realizar, em 2016, um levantamento das pessoas que estão ocupando no momento as habitações e realizar um estudo social, incluindo o auxílio na preparação da documentação completa para renovação do contrato de comodato.

A despeito das dificuldades de gestão que envolveram as casas em comodato, acredita-se que seja uma forma de possibilitar habitações dignas para famílias que, devido à renda, não teriam condições de comprar a habitação, mesmo com longos períodos de financiamentos. Além disso, quando forem alterados para contratos de menor duração, essas casas poderão ser utilizadas por outras famílias, em uma espécie de rodízio, que era o conceito inicial do projeto. Desse modo, famílias que estão temporariamente em uma situação financeira difícil morariam nelas por um determinado período, sendo acompanhadas pela Secretaria de Promoção Social, mas, se essa situação for alterada, as casas poderão atender outras famílias em situação de vulnerabilidade social.

\subsubsection{Limites tênues entre poder público e iniciativa privada | município de Americana}

Em Americana, nas áreas do Jardim da Paz, do Parque da Liberdade e do Jardim dos Lírios, foram realizados diversos empreendimentos de Habitação de Interesse Social que merecem destaque por apresentarem procedimentos não convencionais no seu processo de produção.

Na área do Jardim da Paz, a prefeitura realizou a desapropriação de uma área particular e, a partir dela, realizou diversos empreendimentos de interesse social: 103 lotes urbanizados (1991), 234 casas de mutirão (1992) e forneceu a área para a COHAB-Ribeirão, onde ela realizou 401 casas.

A área onde foram realizados esses empreendimentos era particular e, como pagamento pela desapropriação, os proprietários receberam uma área parcelada e com infraestrutura (com água, esgoto e energia ${ }^{94}$, mas sem asfalto). Assim, foram também

\footnotetext{
${ }^{94}$ A água e o esgoto de todo o loteamento foram realizados pelo DAE (Departamento de Água e Esgoto de Americana), que é uma autarquia; a energia elétrica, pela CPFL, que naquele momento era estatal; e o asfalto foi realizado nos anos 2000 por meio de convênio com o Governo do Estado de São Paulo.
} 
realizados pela prefeitura 637 lotes particulares (1992/93), vendidos pela iniciativa privada, mas como HIS, que, segundo o secretário de Habitação, atendeu em parte à demanda de interesse social. Portanto, apesar de ser um empreendimento particular, decidiu-se incluí-lo no trabalho, pois é parte de uma negociação entre prefeitura e iniciativa privada, e aquela realizou parte da infraestrutura do local, além de terem sido aprovados como lotes de Habitação de Interesse Social.

No Parque da Liberdade, o processo de parcelamento ocorreu de forma semelhante ao Jardim da Paz: uma área particular foi desapropriada e, a partir dela, a prefeitura forneceu a área para a CDHU realizar o Conjunto Habitacional Parque da Liberdade, com 700 casas em 1994, e executou os seguintes empreendimentos de interesse social no Parque da Liberdade: 14 lotes urbanizados em 1996, 156 casas (mutirão) em 1999, 47 lotes urbanizados em 2006, 50 casas (mutirão) em 2006 e 2007.

Além disso, também foram parcelados em 1993, pela prefeitura, os 731 lotes utilizados como pagamento ao proprietário pela desapropriação da área. Ressalta-se que, do mesmo modo que no Jardim da Paz, toda a infraestrutura foi realizada pelo poder público (água e esgoto pela prefeitura; energia e asfalto pelo Estado), inclusive nos lotes particulares.

Outro conjunto realizado de forma semelhante foi o Jardim dos Lírios, cuja área era particular e havia nela a maior favela da cidade. Os proprietários fizeram um acordo com a prefeitura, a qual elaborou o projeto. Dessa forma, obteve-se um número necessário de lotes para atender às famílias que viviam na favela; alguns lotes de interesse social e algumas quadras foram devolvidas aos proprietários, como pagamento pela área.

Resultaram-se, então, os seguintes empreendimentos no Jardim dos Lírios, realizados pela Prefeitura Municipal de Americana: 132 casas (1996), 108 casas (1997 a 1998), 136 casas (1999), 143 sobrados (2000), 41 casas térreas (2002) e 104 casas (2007). Além disso, foram parcelados pela prefeitura e restituídos à iniciativa privada 455 lotes, que foram comercializados pela COOPERTETO e vendidos como Habitação de Interesse Social.

No Jardim dos Lírios, destaca-se a atuação dos agentes no desenvolvimento dos lotes particulares, pois o poder público e a cooperativa realizaram a infraestrutura nos 455 lotes que foram retribuídos à iniciativa privada como pagamento pela área. No entanto, eles foram comercializados pela COOPERTETO (Cooperativa Nacional de Habitação de Interesse Social) e vendidos como HIS para os inscritos no cadastro da Prefeitura Municipal de Americana. 
Pode-se perceber, nesses três casos em Americana, a fusão entre os papéis da iniciativa privada e pública, em que a prefeitura, por um lado, conseguiu por meio de desapropriações obter áreas para diversos empreendimentos de interesse social, e por outro, o poder público utilizou de seu orçamento para prover de infraestrutura áreas particulares, o que as valorizou e pode ter beneficiado determinados proprietários da cidade.

\subsubsection{Casas vendidas em processo de construção município de Campinas}

Serão aqui apresentados cinco conjuntos de Habitação de Interesse Social, realizados pela COHAB Campinas, em que as habitações foram vendidas ainda em processo de construção: DIC V (segunda fase: 85 casas, terceira fase: 271 casas e quarta fase: 376 casas) e Parque Itajaí (terceira fase: 308 casas e quarta fase: 383 casas).

Em 1993, no município de Campinas, a COHAB Campinas iniciou a construção da segunda, terceira e quarta fases do DIC V. Entretanto, os repasses de verba do governo federal ${ }^{95}$ pararam de ocorrer e a obra ficou paralisada por cerca de dois meses. Nesse momento, as pessoas ocuparam esses lotes com a obra ainda em construção. Havia alguns lotes que estavam apenas com a estrutura radier executada; outros tinham paredes; alguns possuíam habitações com cobertura e ainda havia lotes em que a obra não havia iniciado.

A COHAB Campinas conseguiu obter a documentação para reintegração de posse da área, mas a prefeitura, para evitar um desgaste político, solicitou à COHAB para não reintegrar a área e negociar com as pessoas que ocuparam as construções. Dessa forma, a COHAB realizou um inventário das construções ocupadas para estimar o valor de cada uma e decidiu então comercializar os lotes que tinham sido ocupados e sua respectiva construção, no estágio em que estivesse. A partir dessa situação, os lotes não foram vendidos para as pessoas inscritas na $C O H A B$, e, sim, para aquelas que ocuparam os lotes, o que não as torna menos necessitadas do que as outras pessoas, mas é interessante observar a instituição rompendo as suas próprias "regras" mediante uma tentativa de apaziguar uma situação de "conflito".

Cabe lembrar, como discute Raquel Rolnik (O DESAFIO [...], 2007), que a compra e a posse são duas formas legítimas de se adquirir a propriedade privada no Brasil. A despeito disso, a COHAB Campinas, juntamente com a prefeitura municipal, decidiu rapidamente

\footnotetext{
${ }^{95}$ Acredita-se que essa paralisação da verba do governo federal tenha sido reflexo do fim do Banco Nacional de Habitação $(B N H)$, pois era um momento de transição em que a gestão dos recursos federais deixara de ser realizada pelo BNH (em 1986) e passara a ocorrer pela Caixa.
} 
vender as construções ocupadas às pessoas, suprimindo o direito delas de adquirir a propriedade por meio da posse.

No período concomitante ao que essa situação ocorreu, a mesma construtora realizara as obras da terceira e quarta fases do Parque Itajaí, que também se encontravam paralisadas em função da falta de repasse de verbas. Com receio de que essa área também fosse ocupada, a COHAB Campinas decidiu vender as casas em processo de construção. Nesse caso, as pessoas eram chamadas em grupos, conforme o cadastro da COHAB Campinas, e iam, juntamente com técnicos da COHAB, até o local da obra para escolher em que estágio da construção preferiam adquiri-la. Para facilitar, o processo ocorreu quadra a quadra. Desse modo, foram vendidas para os inscritos no cadastro da COHAB Campinas as 308 e 383 casas em construção, respectivamente, da terceira e quarta fases do Parque Itajaí.

Apesar da complexidade da situação desses conjuntos, decidiu-se, na sistematização das informações, considerar a entrega de lotes urbanizados, conforme consta nos itens 32 a 36 da Tabela 8 (p. 82).

Pode-se notar, nesses casos da COHAB Campinas, uma série de mudanças nos procedimentos habituais de entrega dos conjuntos. Destaca-se, ainda, que a COHAB entregou, com o apoio da Prefeitura de Campinas, 1.423 casas ainda em construção, e para várias famílias não foi fácil dispender de recursos para finalizar as obras, muitas vezes sendo obrigadas a ocuparem as casas sem as devidas finalizações da obra. Além disso, os conjuntos foram entregues com infraestruturas parciais, arruamento, luz e água. Apenas cerca de dez anos após, por volta de 2003, é que foi realizado o esgoto, enquanto a drenagem e a pavimentação foram realizadas por volta de $2010^{96}$.

\subsection{Municípios que se destacam na produção de HIS na RMC}

A seguir, constam as tabelas com as quantidades de unidades habitacionais produzidas nos municípios da Região Metropolitana de Campinas (RMC), segundo o levantamento realizado e os totais de domicílios urbanos nos municípios, conforme dados do IBGE, de modo que seja possível perceber quais municípios apresentam os maiores percentuais de produção de HIS e em que período ocorrem esses picos de produção, relacionando com as políticas ou programas públicos. A partir desses dados, também será

\footnotetext{
${ }^{96}$ As informações sobre a data de entrega das infraestruturas são uma aproximação, pois foram obtidas a partir de conversas com técnicos da COHAB Campinas, mas não foi possível ter acesso à documentação referente.
} 
possível discutir se a maior quantidade de instrumentos urbanísticos nos planos diretores (cf. segundo capítulo) reflete em uma maior produção de Habitação de Interesse Social.

Primeiramente, apresentam-se os totais absolutos de unidades habitacionais de interesse social realizados nos municípios da RMC. Esses totais de unidades produzidas foram obtidos a partir dos levantamentos realizados nos municípios, conforme Tabela 6 a Tabela 25 (p. 75 a 113). Esses totais de HIS são apresentados na Tabela 26 abaixo, em quatro períodos: de 1964 até a década de 1970, na década de 1980, na década de 1990 e, por último, de 2000 até 2014. Ressalta-se que esses períodos para apresentação foram uma escolha metodológica para que as quantidades de unidades de interesse social pudessem ser comparadas com os totais de domicílios, conforme os dados do censo do IBGE de cada década.

Tabela 26 - Número de unidades habitacionais produzidas na RMC de 1964 até 2014

\begin{tabular}{|lr|r|r|r|r|}
\cline { 2 - 7 } \multicolumn{1}{c|}{} & \multicolumn{6}{c}{ Número de unidades de Habitação de Interesse Social } \\
\multicolumn{1}{c}{ Municípios } & $\begin{array}{c}\text { De 1964) } \\
\text { a 1979 }\end{array}$ & $\begin{array}{c}\text { De 1980 } \\
\text { a 1989 }\end{array}$ & $\begin{array}{c}\text { De 1990 } \\
\text { a 1999 }\end{array}$ & $\begin{array}{c}\text { De 2000 } \\
\text { a 2014 }\end{array}$ & \multicolumn{1}{c|}{ Total } \\
\hline Americana & $\mathbf{7 0 9}$ & 2.489 & 6.191 & 5.755 & 15.144 \\
\hline Artur Nogueira & 0 & 932 & 1.242 & 231 & 2.405 \\
\hline Campinas & 9.641 & 8.392 & 13.119 & 28.529 & 59.681 \\
\hline Cosmópolis & 465 & 950 & 797 & 1.192 & 3.404 \\
\hline Eng. Coelho & - & - & - & 465 & 465 \\
\hline Holambra & - & - & 362 & 0 & 362 \\
\hline Hortolândia & - & - & - & 6.425 & 6.425 \\
\hline Indaiatuba & 640 & 2.239 & 2.163 & 2.098 & 7.140 \\
\hline Itatiba & 520 & 1.152 & 1.413 & 2.058 & 5.143 \\
\hline Jaguariúna & 70 & 1.078 & 517 & 2.221 & 3.886 \\
\hline Monte Mor & 57 & 0 & 202 & 298 & 557 \\
\hline Morungaba & 44 & 153 & 147 & 191 & 535 \\
\hline Nova Odessa & 99 & 556 & 458 & 2.418 & 3.531 \\
\hline Paulínia & 899 & 1.891 & 3.223 & 2.645 & 8.658 \\
\hline Pedreira & 389 & 323 & 830 & 615 & 2.157 \\
\hline Santa Bárbara d'Oeste & 237 & 1.280 & 3.338 & 1.300 & 6.155 \\
\hline Santo Antônio de Posse & 0 & 125 & 323 & 644 & 1.092 \\
\hline Sumaré & 591 & 1.705 & 500 & 9.231 & 12.027 \\
\hline Valinhos & 1.589 & 765 & 1.737 & 3.070 & 7.161 \\
\hline Vinhedo & 102 & 611 & 981 & 1.929 & 3.623 \\
\hline Total & $\mathbf{1 6 . 0 5 2}$ & $\mathbf{2 4 . 6 4 1}$ & $\mathbf{3 7 . 5 4 3}$ & $\mathbf{7 1 . 3 1 5}$ & $\mathbf{1 4 9 . 5 5 1}$ \\
\hline
\end{tabular}

Fonte: dados sistematizados pela autora a partir do levantamento realizados nos municípios da Região Metropolitana de Campinas, bem como COHAB, CDHU e CEF.

OBS: os dados na cor vermelha referem-se ao período de maior produção de unidades habitacionais em cada município.

Ao observar os totais de unidades produzidos a partir das comparações nos períodos dos diferentes municípios da RMC, é possível realizar algumas considerações. Destaca-se que, nos municípios de Engenheiro Coelho, Holambra e Hortolândia, não foram realizadas as 
comparações por serem municípios fundados recentemente, que não apresentam produções em todos os períodos. Para facilitar a leitura, foram destacados na Tabela 26 (p. 119), na cor vermelha, os períodos com maior produção em cada município.

Percebe-se que, dos vinte municípios da RMC, ou dos dezessete utilizados na análise, onze apresentam um maior número de HIS no último período, de 2000 a 2014, embora o período seja maior que outros, contemplando catorze anos de produção. Acredita-se que essa maior produção esteja diretamente vinculada ao Programa Minha Casa Minha Vida do governo federal. Entretanto, entre esses onze, há dois municípios de porte pequeno que não apresentam o MCMV: Monte Mor, em que as unidades do último período foram realizadas pela $\mathrm{CDHU}$; e Morungaba, em que as 191 unidades foram implementadas pela prefeitura municipal, com financiamento pela Caixa Econômica Federal ${ }^{97}$. Em outros quatro desses onze municípios, houve o MCMV, mas ele foi responsável pela minoria das unidades realizadas no período: Itatiba, onde a CDHU realizou a maioria das unidades; Nova Odessa, em que a maioria das unidades foi realizada pelo Programa de Arrendamento Residencial, outro programa do governo federal; Santo Antônio de Posse, em que a prefeitura realizou a maioria das unidades; e Vinhedo, em que a maior parte das unidades foi realizada pela prefeitura municipal, juntamente com a iniciativa privada. Há cinco municípios em que a produção do MCMV foi responsável pela maioria das unidades: Campinas, Cosmópolis, Jaguariúna, Sumaré e Valinhos. Destaca-se o caso de Campinas, onde há dois grandes empreendimentos MCMV para a faixa 1 do programa - Bassoli, com 2.380, e Sírius, com 2.620 unidades habitacionais -, enquanto em Jaguariúna mais da metade das unidades do último período (1.116) foram realizadas para a faixa 3 do programa ${ }^{98}$.

Pode-se notar que há cinco municípios em que maior produção ocorre na década de 1990: Americana, Artur Nogueira, Paulínia, Pedreira e Santa Bárbara d'Oeste (ver Tabela 26). Em Americana, a maioria dessas unidades são decorrentes das parcerias entre iniciativa privada e poder público, conforme foi apresentado no item "Limites tênues entre poder público e iniciativa privada | município de Americana" (p. 115). Em Artur Nogueira, a maioria das unidades da década de 1990 são lotes urbanizados realizados pela prefeitura municipal, embora haja também unidades da CDHU e da iniciativa privada. Em Paulínia, mais da metade das unidades são de um empreendimento realizado pela Cooperativa Regional de Habitação Popular e prefeitura municipal (1.343 unidades). Além disso, a COHAB realizou

\footnotetext{
${ }^{97}$ As especificações sobre os conjuntos de Habitações de Interesse Social, seus agentes e as formas de realização podem ser observadas nas tabelas relativas à produção de cada município, apresentadas no início deste capítulo (p. 76 a 113).

${ }^{98} \mathrm{Em}$ Campinas, do total de 28.529 unidades habitacionais realizadas no último período (de 2000 a 2014), as faixas 2 e 3 do Programa Minha Casa Minha Vida representam aproximadamente um terço (8.958 unidades).
} 
1.039 casas, a prefeitura municipal doou 631 unidades (casas e lotes) e a CDHU realizou 210 casas. Em Pedreira, todas as unidades de interesse social da década de 1990 foram realizadas pela CDHU. Em Santa Bárbara d'Oeste, a maioria das unidades foi da CDHU (1614); outras 1.000 unidades foram feitas por meio do Programa de Moradia Popular da CEF, em parceria com a iniciativa privada; a prefeitura, com financiamento da CEF, ainda realizou 538 unidades, e a Cooperativa de Habitação (CIESP / FIESP) realizou 186 casas. É possível notar a importância da atuação da CDHU e das prefeituras municipais na produção de HIS da década de 1990.

Para a próxima análise, serão considerados os valores levantados da produção de HIS, conforme Tabela 26 (p. 119) e os totais de domicílios, conforme o censo do IBGE, de modo que seja possível obter os percentuais de HIS produzidas nos municípios. Para a comparação com o total de domicílios (IBGE), como primeira etapa, foram somadas as HIS de modo que se pudesse obter o total de unidades realizadas até cada período, conforme as quatro primeiras colunas da Tabela 27. Na mesma tabela, apresentam-se nas quatro últimas colunas os dados de domicílios, segundo o censo do IBGE de cada década, lembrando que foram considerados apenas os domicílios urbanos, e não o total de domicílios.

Tabela 27 - Total de HIS e total de domicílios urbanos até cada período analisado

\begin{tabular}{|c|c|c|c|c|}
\hline \multirow{2}{*}{ Municípios } & \multicolumn{4}{|c|}{$\begin{array}{c}\text { Número Total de HIS Implantadas } \\
\text { de } 1964 \text { até }\end{array}$} \\
\hline & \begin{tabular}{c|} 
Déc \\
1970
\end{tabular} & $\begin{array}{l}\text { Déc } \\
1980\end{array}$ & $\begin{array}{l}\text { Déc } \\
1990\end{array}$ & 2014 \\
\hline Americana & 709 & 3.198 & 9.389 & 15.144 \\
\hline Artur Nogueira & 0 & 932 & 2.174 & 2.405 \\
\hline Campinas & 9.641 & 18.033 & 31.152 & 59.681 \\
\hline Cosmópolis & 465 & 1.415 & 2.212 & 3.404 \\
\hline Eng. Coelho & -- & - & 0 & 465 \\
\hline Holambra & -- & -- & 362 & 362 \\
\hline Hortolândia & -- & - & 0 & 6.425 \\
\hline Indaiatuba & 640 & 2.879 & 5.042 & 7.140 \\
\hline Itatiba & 520 & 1.672 & 3.085 & 5.143 \\
\hline Jaguariúna & 70 & 1.148 & 1.665 & 3.886 \\
\hline Monte Mor & 57 & 57 & 259 & 557 \\
\hline Morungaba & 44 & 197 & 344 & 535 \\
\hline Nova Odessa & 99 & 655 & 1.113 & 3.531 \\
\hline Paulínia & 899 & 2.790 & 6.013 & 8.658 \\
\hline Pedreira & 389 & 712 & 1.542 & 2.157 \\
\hline $\begin{array}{l}\text { Santa Bárbara } \\
\text { d'Oeste }\end{array}$ & 237 & 1.517 & 4.855 & 6.155 \\
\hline Santo A. de Posse & 0 & 125 & 448 & 1.092 \\
\hline Sumaré & 591 & 2.296 & 2.796 & 12.027 \\
\hline Valinhos & 1.589 & 2.354 & 4.091 & 7.161 \\
\hline Vinhedo & 102 & 713 & 1.694 & 3.623 \\
\hline Total & 16.052 & 40.693 & 78.236 & 149.551 \\
\hline
\end{tabular}

\begin{tabular}{|r|r|r|r|}
\hline \multicolumn{4}{|c|}{$\begin{array}{c}\text { Conforme censos do IBGE, } \\
\text { total de domicílios urbanos até }\end{array}$} \\
\hline 1980 & \multicolumn{1}{|c|}{$\mathbf{1 9 9 1}$} & \multicolumn{1}{c|}{$\mathbf{2 0 0 0}$} & \multicolumn{1}{c|}{$\mathbf{2 0 1 0}$} \\
\hline 27.906 & 39.901 & 52.364 & 67.399 \\
\hline 1.590 & 3.405 & 8.272 & 12.186 \\
\hline 138.602 & 217.936 & 279.076 & 342.935 \\
\hline 4.320 & 8.271 & 11.886 & 16.615 \\
\hline-- & -- & 1.828 & 3.322 \\
\hline-- & -- & 1.082 & 2.455 \\
\hline-- & -- & 40.370 & 55.371 \\
\hline 10.910 & 22.914 & 39.792 & 60.772 \\
\hline 8.075 & 13.450 & 18.182 & 26.392 \\
\hline 2.075 & 4.651 & 6.994 & 13.170 \\
\hline 1.606 & 5.246 & 9.043 & 13.590 \\
\hline 969 & 1.543 & 2.080 & 3.024 \\
\hline 4.327 & 7.944 & 11.520 & 15.588 \\
\hline 4.145 & 7.966 & 13.628 & 24.280 \\
\hline 4.490 & 6.731 & 9.381 & 12.672 \\
\hline 15.561 & 34.209 & 46.318 & 54.488 \\
\hline 1.663 & 2.857 & 4.057 & 5.755 \\
\hline 20.433 & 53.043 & 52.961 & 72.674 \\
\hline 8.717 & 15.279 & 22.237 & 32.117 \\
\hline 4.549 & 8.112 & 12.519 & 18.814 \\
\hline $\mathbf{2 5 9 . 9 3 8}$ & $\mathbf{4 5 3 . 4 5 8}$ & $\mathbf{6 4 3 . 5 9 0}$ & $\mathbf{8 5 3 . 6 1 9}$ \\
\hline
\end{tabular}

Fonte: dados sistematizados pela autora a partir do levantamento realizado nos municípios da Região Metropolitana de Campinas, bem como COHAB, CDHU e CEF (quatro primeiras colunas) e dados dos censos do IBGE de 1980, 1991, 2000 e 2010 (quatro últimas colunas). 
A Tabela 27 foi apresentada para que seja possível compreender quais dados foram utilizados para gerar a Tabela 28 (p. 123). Como se pode ler na Tabela 27, o último período considera as Habitações de Interesse Social produzidas até 2014, entretanto, para os totais de domicílios serão considerados os valores do censo de 2010. Embora haja essa diferença em relação a outros períodos, não há implicações quando forem realizadas as comparações entre os percentuais dos vários municípios, pois para todos haverá a mesma diferença de quatro anos ao gerar os percentuais. De modo semelhante ocorre no censo que foi realizado em 1991; embora haja uma diferença de um ano, o comparativo dos percentuais (HIS/total de domicílios) entre os diferentes municípios é válido para as análises.

Outra questão metodológica importante foi a definição dos períodos a serem analisados. Por exemplo, se o primeiro período da produção de HIS iria até 1979 ou até 1980, assim como os subsequentes, considerando que foi definido que seriam utilizados os dados gerados pelos censos do IBGE para a contagem de domicílios. O censo é realizado a cada 10 anos, e os dados englobam até a noite de 31 de julho para as totalizações ${ }^{99}$. Desse modo, por exemplo, se o período considerado para as HIS fosse até 1980 (todo o ano de 1980), pelo censo do IBGE, haveria meio ano a menos no total de domicílios; de forma igual, ao considerar o período das HIS até 1979 , haveria meio ano a mais de domicílios que não seriam contados. Assim, considerando que a diferença no número de domicílios seria a mesma em ambas as opções - meio ano -, optou-se por finalizar o período em 1979, em função da convenção de década (1980). De modo similar, os outros períodos finalizam em 1989, 1999 e o último em 2014. Ressalta-se, ainda, que a periodização por décadas possibilitou a percepção de nuances da dinâmica metropolitana. Observa-se que a mesma periodização será utilizada nos mapeamentos que serão apresentados no próximo capítulo.

Após a compreensão dos dados utilizados e da metodologia para gerar a Tabela 28 (p. 123), podem-se, então, realizar análises dos percentuais de HIS em cada município da Região Metropolitana de Campinas. Primeiramente, observa-se a média dos valores, e que a percentagem de HIS aumentou a cada período, em função do aumento das políticas públicas voltadas para o setor habitacional, conforme discutido no capítulo 1 deste trabalho.

Apenas para contribuir na leitura da tabela, destacaram-se na cor vermelha e em negrito os três municípios com maior percentual em cada período, e na cor vermelha, os municípios que apresentaram percentuais acima da média naquele período. Destacam-se,

\footnotetext{
99 Conforme informações do site do IBGE, são recenseadas todas as pessoas que moravam no domicílio nessa data. Ou seja, as pessoas que nasceram depois de 31 de julho não são recenseadas; e as pessoas que faleceram depois de 31 de julho devem ser contadas, pois faziam parte do domicílio na data de referência e, portanto, estão incluídas.
} 
então, cinco municípios com os maiores percentuais em alguns períodos e em outros, acima da média, Artur Nogueira, Cosmópolis, Jaguariúna, Paulínia e Valinhos. Entre eles, observase Paulínia com os maiores percentuais em todos os períodos, acredita-se que em função da grande receita devido à instalação da Rodhia e da REPLAN (Refinaria de Paulínia) ${ }^{100}$. 0 município de Jaguariúna caracteriza-se por ser um local de implantação de indústrias de alta tecnologia ${ }^{101}$, e Valinhos, que também apresenta uma vocação industrial (CAIADO, 1998). Esses três municípios caracterizam-se pela ocupação de condomínios e loteamentos fechados das classes de maior poder aquisitivo (CAIADO; PIRES, 2006), enquanto Cosmópolis e Artur Nogueira apresentam outra característica territorial, de ocupação mais popular.

Tabela 28 - Percentual de Habitação de Interesse Social em relação ao total de domicílios urbanos nos municípios da Região Metropolitana de Campinas

\begin{tabular}{|c|c|c|c|c|}
\hline \multirow{2}{*}{ Municípios } & \multicolumn{4}{|c|}{$\begin{array}{l}\text { Percentual de HIS em relação ao total de } \\
\text { domicílios urbanos produzidos até }\end{array}$} \\
\hline & Déc. 1970 & Déc. 1980 & Déc. 1990 & 2014 \\
\hline Americana & $2,54 \%$ & $8,01 \%$ & $17,93 \%$ & $22,47 \%$ \\
\hline Artur Nogueira & $0,00 \%$ & $27,37 \%$ & $26,28 \%$ & $19,74 \%$ \\
\hline Campinas & $6,96 \%$ & $8,27 \%$ & $11,16 \%$ & $17,40 \%$ \\
\hline Cosmópolis & $10,76 \%$ & $17,11 \%$ & $18,61 \%$ & $20,49 \%$ \\
\hline Eng. Coelho & -- & -- & $0,00 \%$ & $14,00 \%$ \\
\hline Holambra & -- & -- & $33,46 \%$ & $14,75 \%$ \\
\hline Hortolândia & -- & -- & $0,00 \%$ & $11,60 \%$ \\
\hline Indaiatuba & $5,87 \%$ & $12,56 \%$ & $12,67 \%$ & $11,75 \%$ \\
\hline Itatiba & $6,44 \%$ & $12,43 \%$ & $16,97 \%$ & $19,49 \%$ \\
\hline Jaguariúna & $3,37 \%$ & $24,68 \%$ & $23,81 \%$ & $29,51 \%$ \\
\hline Monte Mor & $3,55 \%$ & $1,09 \%$ & $2,86 \%$ & $4,10 \%$ \\
\hline Morungaba & $4,54 \%$ & $12,77 \%$ & $16,54 \%$ & $17,69 \%$ \\
\hline Nova Odessa & $2,29 \%$ & $8,25 \%$ & $9,66 \%$ & $22,65 \%$ \\
\hline Paulínia & $21,69 \%$ & $35,02 \%$ & $44,12 \%$ & $35,66 \%$ \\
\hline Pedreira & $8,66 \%$ & $10,58 \%$ & $16,44 \%$ & $17,02 \%$ \\
\hline Santa Bárbara d'Oeste & $1,52 \%$ & $4,43 \%$ & $10,48 \%$ & $11,30 \%$ \\
\hline Santo Antônio de Posse & $0,00 \%$ & $4,38 \%$ & $11,04 \%$ & $18,97 \%$ \\
\hline Sumaré & $2,89 \%$ & $4,33 \%$ & $5,28 \%$ & $16,55 \%$ \\
\hline Valinhos & $18,23 \%$ & $15,41 \%$ & $18,40 \%$ & $22,30 \%$ \\
\hline Vinhedo & $2,24 \%$ & $8,79 \%$ & $13,53 \%$ & $19,26 \%$ \\
\hline Média dos municípios da RMC & $6,18 \%$ & $8,97 \%$ & $12,16 \%$ & $17,52 \%$ \\
\hline
\end{tabular}

Fonte: dados sistematizados pela autora a partir do levantamento realizado nos municípios da Região Metropolitana de Campinas, bem como COHAB, CDHU e CEF e dados dos censos do IBGE de 1980, 1991,2000 e 2010.

\footnotetext{
${ }^{100}$ A REPLAN foi inaugurada em maio de 1972 e sua atividade iniciou três meses antes da inauguração. Cerca de 126 mil barris (20 mil $\mathrm{m}^{3}$ ) eram processados por dia; atualmente a capacidade é de 415 mil barris/dia (informação do site da REPLAN, acessado em outubro de 2015).

${ }^{101}$ A instalação de indústrias de alta tecnologia ao longo da rodovia Adhemar de Barros (SP-340) foi favorecida principalmente devido à implantação às margens dessa rodovia do Polo II da Ciatec (Companhia de Desenvolvimento do Polo de Alta Tecnologia de Campinas), grande área destinada a indústrias de alta tecnologia em Campinas.
} 
Cabe ainda destacar cinco municípios que não apresentam em nenhum dos períodos percentual de HIS acima da média: Engenheiro Coelho, Hortolândia, Monte Mor, Santa Bárbara d'Oeste e Sumaré. Entre eles, apenas Santa Bárbara d'Oeste apresenta uma escala maior; os outros são municípios pequenos, que no censo de 2010 apresentaram menos de 50.000 habitantes (ver Tabela 1, p. 32). Ressalta-se que, a despeito de três desses municípios - Hortolândia, Monte Mor e Sumaré - caracterizarem-se como local de moradia de "populações pobres, expulsas de áreas urbanas mais valorizadas" (CAIADO, 1998, p. 469), eles apresentam baixos índices de Habitações de Interesse Social, o que indica uma carência ainda maior dessas habitações. É interessante lembrar que se trata de uma região metropolitana onde os movimentos pendulares de trabalhadores são recorrentes. Assim, a questão da HIS deveria ser tratada de forma conjunta, no sentido de reduzir o desequilíbrio entre municípios com maior atividade econômica e oferta de empregos e esses municípios "dormitórios", que apresentam, em geral, uma receita baixa.

Ao focar a análise no último período, de 2000 a 2014, destacam-se Americana, Jaguariúna e Paulínia como os municípios com os maiores percentuais de HIS e outros com a produção de HIS acima da média da percentagem do período: Artur Nogueira, Cosmópolis, Itatiba, Morungaba, Nova Odessa, Santo Antônio de Posse, Valinhos e Vinhedo. Pode-se notar que, entre os oito municípios com percentual acima da média de HIS, cinco encontram-se no grupo de municípios classificado como A no segundo capítulo (p. 63), devido à maior quantidade de instrumentos urbanísticos voltados para HIS. Entretanto, entre os três com maiores produções, Americana encontra-se no grupo B (p. 63), enquanto Jaguariúna e Paulínia, no grupo C (p. 64) - com nenhum ou pouquíssimos instrumentos para a produção de Habitação de Interesse Social.

Acredita-se que nesse período seja possível observar reflexos dos instrumentos urbanísticos dos planos diretores, instituídos a partir da aprovação do Estatuto da Cidade em 2001. Para os três municípios com maior produção de HIS, essa produção talvez esteja relacionada à receita municipal. No entanto, para os outros municípios é possível observar essa relação, pois, entre os sete municípios do grupo A (p. 63), com muitos instrumentos voltados a HIS, apenas Hortolândia e Pedreira não apresentaram um percentual de HIS acima da média da região, sendo que Pedreira teve um valor bastante próximo da média. Por outro lado, entre os sete municípios do grupo $\mathrm{C}$, com nenhum ou pouquíssimos instrumentos urbanísticos para HIS em seus planos diretores, apenas quatro deles apresentaram produção de HIS abaixo da média da produção do período. 
É possível observar que, se, por um lado, a presença nos planos diretores de instrumentos voltados à produção de HIS, especialmente as ZEIS (Zonas Especiais de Interesse Social), é parte de um cenário favorável à produção de HIS, por outro lado, esses instrumentos não são determinantes, pois pode-se perceber nos dados que a ausência deles não diminui a produção de HIS. É claro que essa é apenas uma primeira análise quantitativa, mas também pode ser discutida a questão da localização e a faixa de renda para a qual foram produzidas essas habitações. Por exemplo, em Jaguariúna, percebe-se um grande percentual, entretanto, mais da metade desse valor é devido à produção da faixa de renda 3 do Minha Casa Minha Vida.

Constata-se que a presença de instrumentos urbanísticos nos planos diretores pode ter influenciado uma maior produção de HIS, mas ela não é determinante dessa produção. Houve um esforço metodológico em apresentar os números de habitações produzidas, pois eles representam parte dos resultados das políticas de habitação. No entanto, devem-se considerar as especificidades de cada município e, principalmente, a importância da localização dessas habitações, pois a qualidade das moradias está intrinsecamente ligada ao lugar que elas ocupam na cidade, o que representa a possibilidade de acesso aos serviços básicos e equipamentos culturais e de lazer, além da questão simbólica e cultural associada a cada espaço da cidade, valores que refletem o preço da terra. No próximo capítulo, as habitações levantadas serão mapeadas nos municípios da RMC. 


\section{Capítulo IV - A implantação das Habitações de Interesse Social na RMC de 1964 a 2014}

Inicialmente neste capítulo, será apresentada a metodologia utilizada para a localização e o desenho do perímetro das Habitações de Interesse Social (HIS) levantadas na Região Metropolitana de Campinas (RMC), lembrando que o período do levantamento contempla as HIS produzidas entre 1964 e 2014. Depois serão apresentados os mapeamentos realizados dessas HIS, identificando as formas de ocupações territoriais nos municípios da RMC, de modo que se possam perceber os padrões correspondentes a elas. Essas implantações são observadas em duas escalas: no âmbito de cada município e na escala da RMC como um todo.

Por meio do mapeamento desses conjuntos, objetiva-se a construção de um quadrosíntese do território, no qual seja possível relacionar os princípios instituídos pelas políticas públicas habitacionais com o que ocorre na realidade urbana e metropolitana. Pretende-se, ainda, possibilitar a compreensão de questões como: a existência de padrões de ocupação dos conjuntos de HIS, as mudanças em suas localizações mediante a configuração de uma região metropolitana, as relações entre a localização dos empreendimentos e a instituição de diversas políticas públicas habitacionais, a análise de como esse conjunto de políticas regula ou não o território e a discussão da coerência dessas políticas com a forma metropolitana de ocupação territorial. Pode-se, então, discutir em que medida as políticas públicas habitacionais federais, estaduais, metropolitanas e municipais são capazes de interferir na estrutura urbana ou reproduzi-la. Pois, embora muitas vezes os planos e políticas habitacionais não discutam a questão territorial e espacial, eles produzem habitações e, portanto, a cidade.

\subsection{Desenvolvimento de Metodologia para o Mapeamento das Habitações de Interesse Social}

Além do levantamento dos conjuntos de Habitação de Interesse Social produzidos na Região Metropolitana de Campinas, é fundamental, para a análise, o mapeamento dessas habitações no território. Para tal, foi necessário o levantamento junto aos órgãos municipais, $\mathrm{COHAB}, \mathrm{CDHU}$ e CEF, destacando-se a dificuldade relacionada à diversidade das bases de informações sobre a localização das Habitações de Interesse Social, que variaram desde mapas digitais (em AutoCAD ou outros softwares) até mapas impressos ou apenas listas com os endereços, sem a espacialização das informações. Além disso, na fase inicial do trabalho, foi utilizado o mapeamento parcial realizado por Silva (2011b). 
Dessa forma, foi necessário desenvolver uma metodologia que permitisse o desenho dos perímetros dessas HIS a partir das mais diferentes formas de obtenção dos dados. Em uma primeira etapa, realizou-se o levantamento em 5 municípios, para desenvolvimento de uma metodologia que posteriormente foi aplicada aos outros 15 municípios da RMC (ver no Mapa 6 os municípios em que as HIS foram mapeadas na primeira etapa). Objetivou-se com essa etapa o estabelecimento de critérios para a elaboração do desenho dos perímetros das HIS, que constituiu um mapa da produção das HIS na RMC, entre 1964 e 2014.

\section{Mapa 6 - Munícipios da RMC em que as HIS foram mapeadas na primeira etapa para} desenvolvimento da metodologia

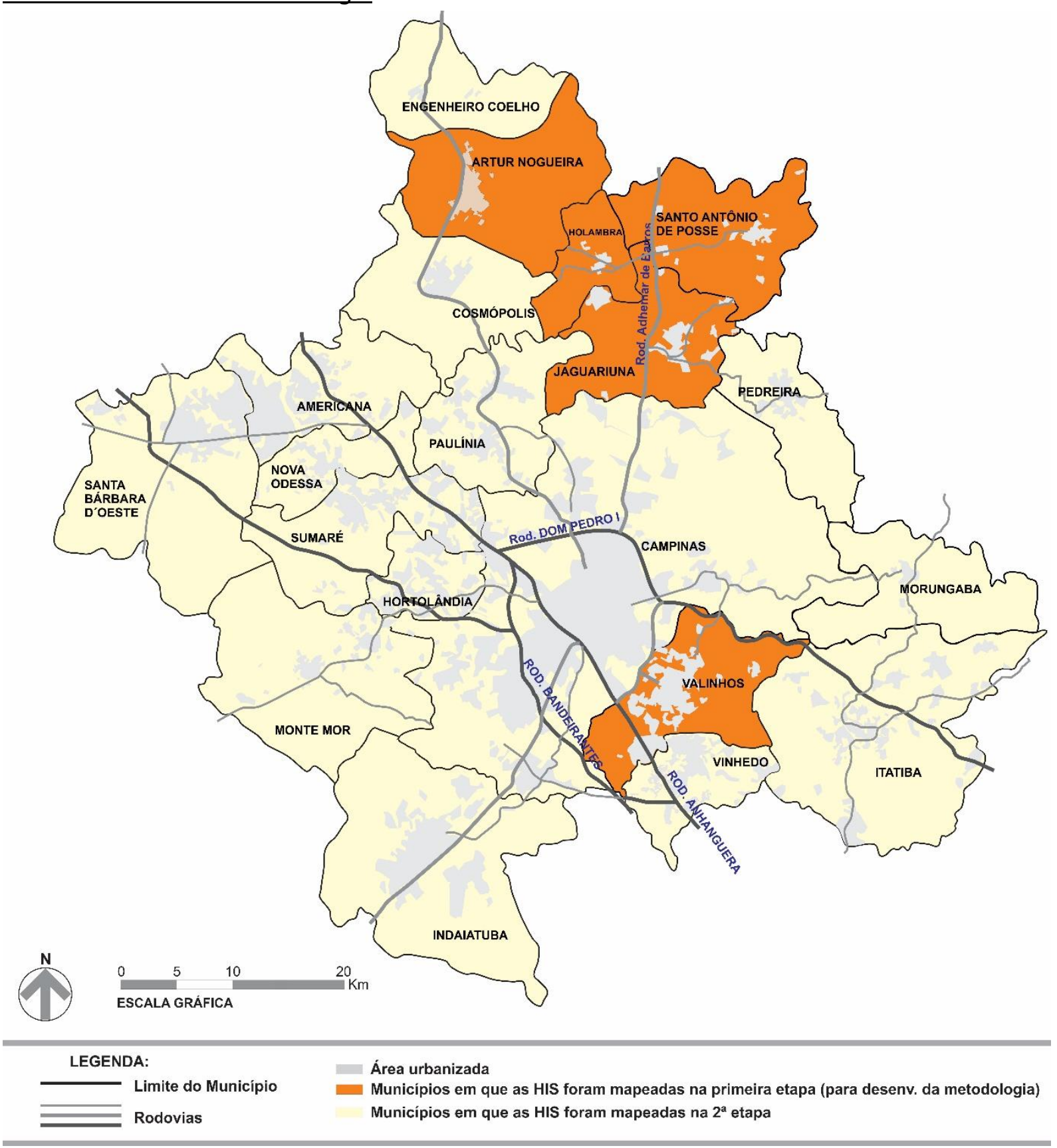

Fonte do mapa: identificação dos municípios realizada pela autora. 


\section{Metodologia utilizada}

As informações sobre a produção de Habitação de Interesse Social (HIS) no município foram obtidas nos seguintes formatos: A) lista com os conjuntos implantados no município (sem localização); B) mapa analógico das HIS implantadas no município; C) mapa digital dos empreendimentos. Quando ocorreu a opção B, digitalizou-se a imagem e, posteriormente, assim como ocorreu com as informações obtidas no formato C, ajustaram-se as escalas para, então, exportar ou redesenhar os mapas, quando foi o caso, no software selecionado para o mapeamento.

Na primeira etapa, foi realizado o levantamento nos seguintes municípios: Holambra, Jaguariúna, Pedreira, Santo Antônio de Posse e Valinhos. Em todos os cinco municípios, as informações existiam ou foram levantadas pelos técnicos municipais, no que se refere ao formato A.

Destaca-se que, na segunda etapa de mapeamento, houve uma maior diversidade na forma de fornecimento das informações. Em alguns municípios, como no caso de Campinas, houve parte das informações no formato $A$, parte no $B$ e parte no $C$, e ainda houve o acesso a trabalhos que realizaram o mapeamento de alguns desses conjuntos, como a dissertação de mestrado de Zaparoli (2010) e o trabalho de Silva, J. (2011b) ${ }^{102}$, que forneceram generosamente os mapeamentos realizados em suas pesquisas. Em alguns casos, como em Artur Nogueira e em Santa Bárbara d'Oeste, as localizações de cada conjunto foram fornecidas, entretanto, em vários municípios, as informações foram obtidas depois de várias entrevistas com técnicos municipais, muitas vezes, por meio de desenhos à mão realizados por eles. Observa-se no Quadro 6 (p. 133) o modo como a informação foi fornecida em cada município.

Apesar de todos os municípios da primeira etapa terem apresentado informações em um mesmo formato, ela foi suficiente para definir os métodos que foram utilizados em todos os outros municípios. Pois a forma A pode ser classificada como a mais "rudimentar" em que os dados podem ser levantados, e os formatos B e C são praticamente decorrentes do A.

A despeito da inexistência de mapas na primeira etapa com dados sobre a produção de HIS no município, foram solicitadas aos técnicos das prefeituras as seguintes

\footnotetext{
${ }^{102}$ A pesquisa de Silva é parte do trabalho de pesquisadores docentes da PUC-Campinas e, mesmo não sendo um trabalho de acesso público, por meio de contato com o autor, ele foi generosamente disponibilizado. Silva, J. (2011b) forneceu mapas com a localização sob a forma de pontos, e não de perímetros, de: 33 conjuntos em Americana, 7 em Artur Nogueira, 46 em Campinas, 9 em Hortolândia, 7 em Indaiatuba, 2 em Jaguariúna, 2 em Paulínia, 10 em Santa Bárbara D'Oeste, 6 em Sumaré e 3 em Valinhos, o que representou importante contribuição ao trabalho.
} 
informações: nome do empreendimento, ano, agente ou parcerias, quantidade de unidades. Percebeu-se que, na maioria deles, essas informações não existiam de forma sistematizada. Assim, houve dificuldade para obtenção desses dados, sendo necessárias várias visitas e telefonemas. Não foi possível, tampouco, solicitar as plantas de aprovação dos empreendimentos, pois, quando isso era mencionado, não havia atendimento por parte dos técnicos. Algumas vezes, o acesso às plantas de aprovação das HIS era negado porque os técnicos alegavam estar sobrecarregados para um levantamento desse porte, outras vezes, porque eles desconheciam essa documentação.

Frente a essa situação, foi necessário desenvolver um método para a localização das HIS. Primeiro, solicitou-se aos técnicos ${ }^{103}$ o nome de apenas uma rua de cada empreendimento. Essa informação era facilmente obtida, pois, de acordo com eles, mesmo no caso de empreendimentos antigos, havia alguns contratos de moradores arquivados.

\section{Figura 1 - Foto aérea da cidade de Pedreira (entorno, a partir da R. Mascarenha de Moraes)}

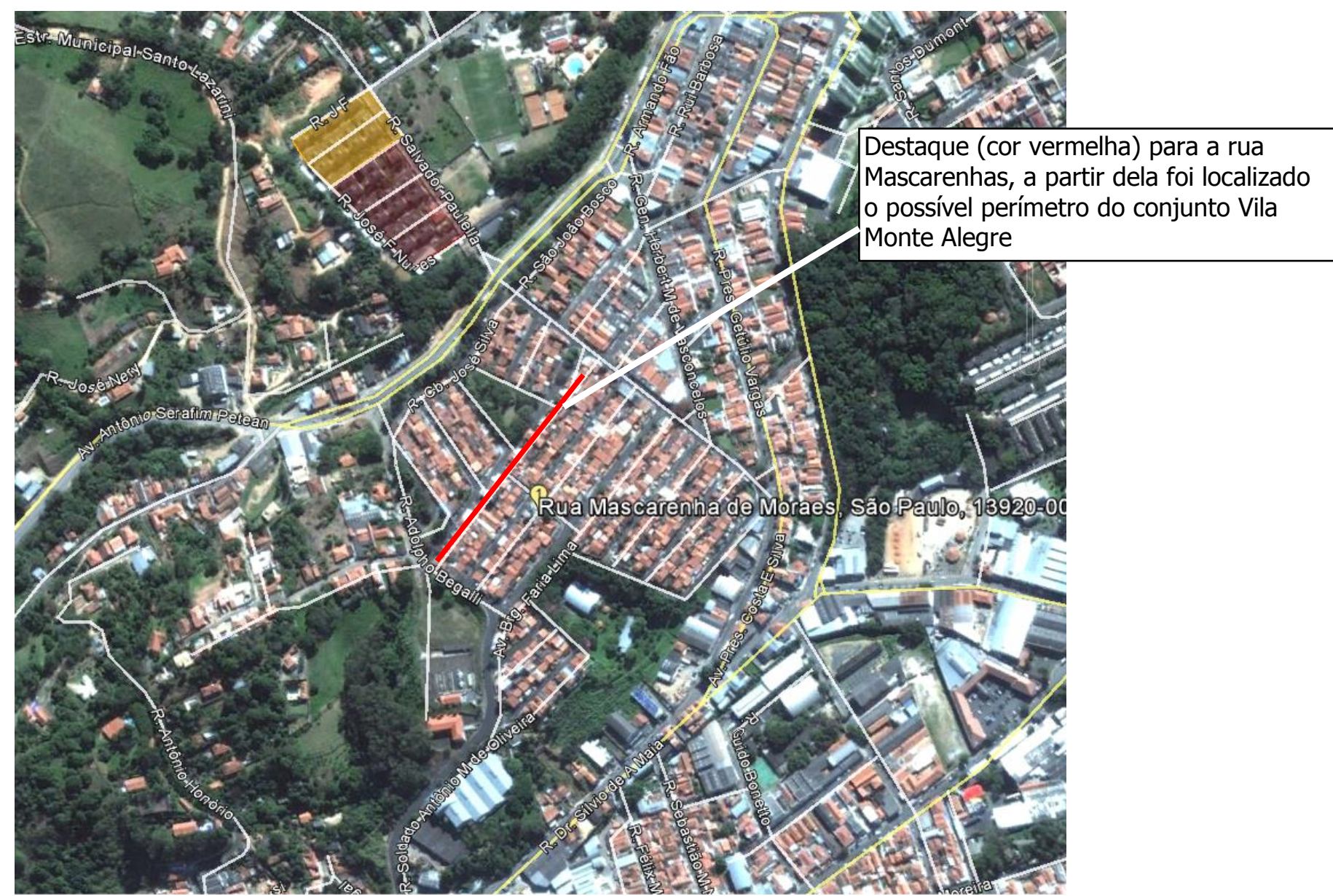

Fonte da imagem: Google Earth, acesso em 05/2014, data da imagem: 31/07/2013.

${ }^{103} \mathrm{~A}$ ideia de solicitar uma rua partiu dos próprios técnicos, pois, quando era questionada a localização do conjunto, diziam que poderiam passar o nome de uma das ruas desse conjunto. 
Tomando por base o endereço de uma rua de cada conjunto de HIS, através do Google Earth, foi possível estabelecer a localização aproximada do conjunto. A partir da foto aérea, tendo como critério o desenho urbano, os tamanhos de lotes e as tipologias das coberturas, pode-se identificar um possível perímetro do conjunto habitacional.

Observa-se, no exemplo da Vila Monte Alegre de Pedreira, a demarcação de uma rua do conjunto, a partir da qual se estabeleceu um possível perímetro. Para a confirmação desse possível perímetro, foram contadas as quantidades de unidades. No exemplo da Vila Monte Alegre, cujo número de unidades habitacionais informado pela prefeitura era de 200 unidades, foram contadas 196 habitações nas possíveis quadras a partir do desenho urbano (ver Figura 2). Quando houve dificuldades na leitura da imagem, recorreu-se às ortofotos da Emplasa $^{104}$, anos de 2010 e 2011. Em alguns casos, foram realizadas visitas à área ou foi utilizada a ferramenta Street View do Google Earth, possibilitando a identificação de fachadas de mesma tipologia, mesmo com as reformas e acréscimos posteriores à obra original.

Figura 2 - Foto aérea de Pedreira (possível perímetro do conjunto de HIS Vila Monte Alegre)

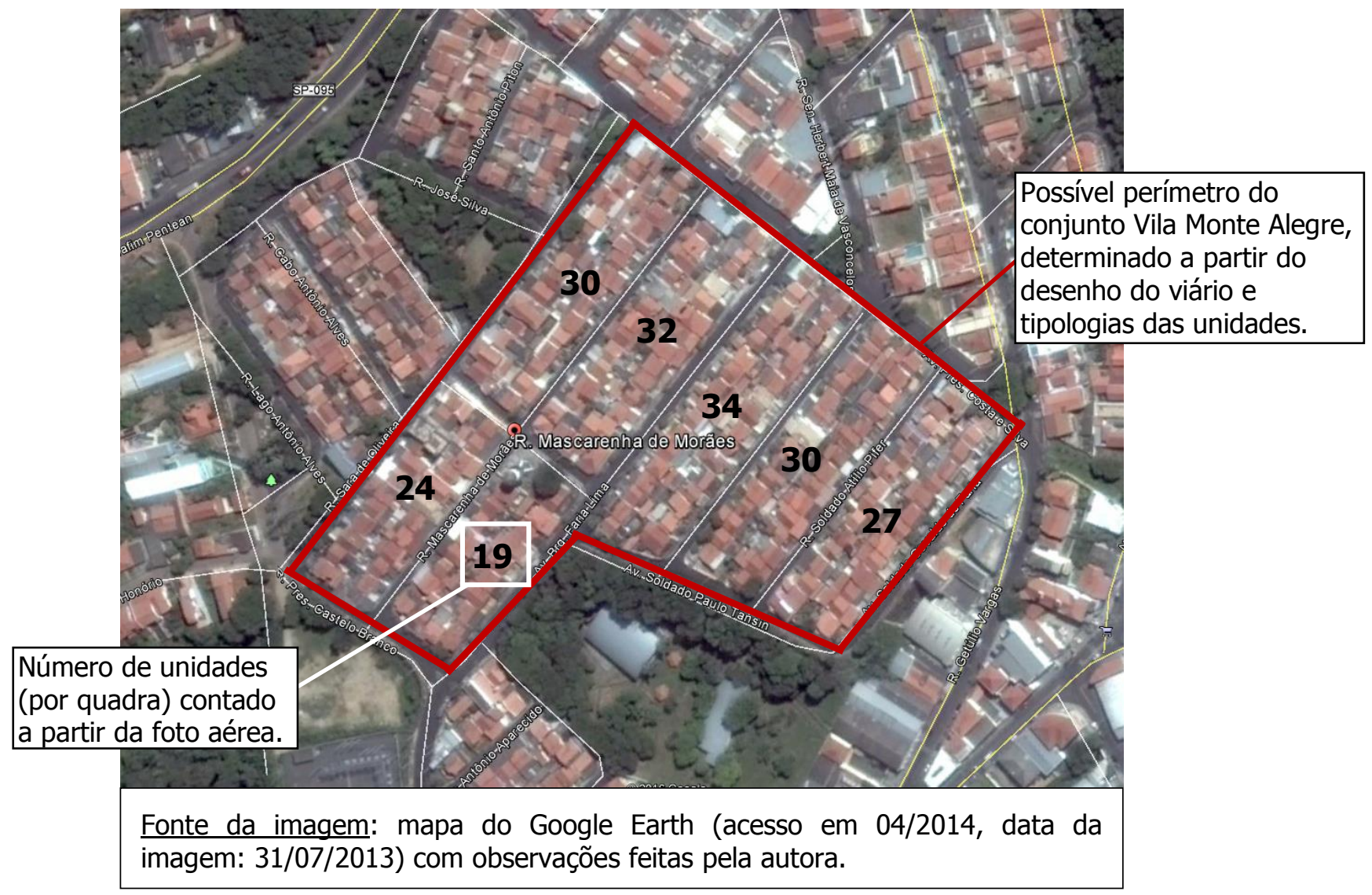

${ }^{104}$ A localização de alguns conjuntos habitacionais de interesse social foi confirmada por meio de ortofotos de alta qualidade. A EMPLASA possui um levantamento bastante recente, realizado em 2010 e 2011, com ortofotos digitais. No site, as ortofotos são disponibilizadas para visualização, mas, para obter essas imagens em alta definição, foi necessária uma requisição formal. Dessa forma, com a assinatura de contrato de licença de uso (em fevereiro de 2014), foi possível obter na EMPLASA 34 ortofotos referentes à Região Metropolitana de Campinas. 
Admitiu-se uma diferença de $5 \%$ (a mais ou a menos) entre a contagem de unidades (a partir da foto aérea) e o número de unidades habitacionais fornecido pelas prefeituras. Quando o erro (considerando o número de unidades contadas na foto aérea) foi maior que $5 \%$ ou não se pôde obter a identificação do perímetro possível a partir dos critérios estabelecidos, foram solicitadas mais informações à prefeitura - nomes de outras ruas ou as plantas de aprovação dos empreendimentos. Como havia poucos conjuntos habitacionais não identificados (a partir do fornecimento de uma rua), nesses casos, os técnicos forneceram as informações necessárias para suas localizações.

$\mathrm{Na}$ delimitação do perímetro das Habitações de Interesse Social, optou-se pela demarcação exclusiva ${ }^{105}$ das unidades habitacionais, desconsiderando escolas, praças, lotes comerciais e similares. Mesmo quando houve acesso às implantações dos conjuntos nas prefeituras, essas áreas foram identificadas, porém, não mapeadas. Isso porque esse mapeamento ocorreria em apenas alguns conjuntos, tornando frágil a posterior comparação entre as dimensões deles.

Considerando os métodos descritos, empregados para o mapeamento das Habitações de Interesse Social, optou-se pela utilização do próprio software Google Earth para a realização dos desenhos dos perímetros das HIS. Primeiramente, por haver a sobreposição de sistema viário e foto aérea, com fácil mecanismo de busca a partir do nome de ruas e avenidas; depois, por ser possível a associação de outros dados aos perímetros desenhados. Dessa forma, os dados foram inseridos de modo que, ao clicar sobre o desenho de um conjunto habitacional, podem-se ler as seguintes informações (colocadas nesta ordem): nome do empreendimento, quantidade de unidades habitacionais, agente financeiro ou parcerias, data e observações. A seguir, o exemplo do mapeamento do Conjunto Monte (Pedreira) finalizado, com as informações associadas ao perímetro do conjunto, conforme Figura 3 (p. 132).

A opção do Google Earth para o mapeamento justifica-se também pelo fato de que seu arquivo é compatível ${ }^{106}$ com programas de geoprocessamento, como ArqGis e QuantumGis, muito utilizados para planejamento urbano. A utilização do software também possibilita que o desenho dos conjuntos habitacionais possa ser feito em diferentes pastas,

\footnotetext{
${ }^{105} \mathrm{Em}$ alguns casos, na contagem de unidades na foto aérea, a partir do método utilizado, estes elementos (escolas, lotes comerciais e outros não residenciais) podem ter sido considerados, mas, em sua maioria, foram excluídos, pois quase sempre é possível identificá-los pelo tamanho do lote e pelo desenho da cobertura, associados à ferramenta Street View do Google Earth.

106 O Google Earth gera automaticamente um arquivo do tipo KMZ e, para exportá-lo para outros programas, deve-se optar pelo arquivo tipo KML (no momento de salvar o arquivo). O arquivo com extensão KML pode ser importado no software ArqGis ou QuantumGis.
} 
que podem ser ou não habilitadas conforme a necessidade de análise. Dessa forma, é possível selecionar quais conjuntos serão observados em cada mapa. É possível, por exemplo, visualizar todos os conjuntos habitacionais na Região Metropolitana de Campinas ou todos os conjuntos em apenas alguns municípios, ou apenas os conjuntos desejados, conforme as pastas estejam ou não habilitadas. Além disso, como se trata de software de acesso livre, facilitará a divulgação e utilização dos mapeamentos pelas prefeituras municipais, uma vez que se pretende fornecê-los a elas.

Figura 3 - Localização da HIS Monte Alegre em Pedreira (exemplo de como as informações são vinculadas aos perímetros dos conjuntos habitacionais)

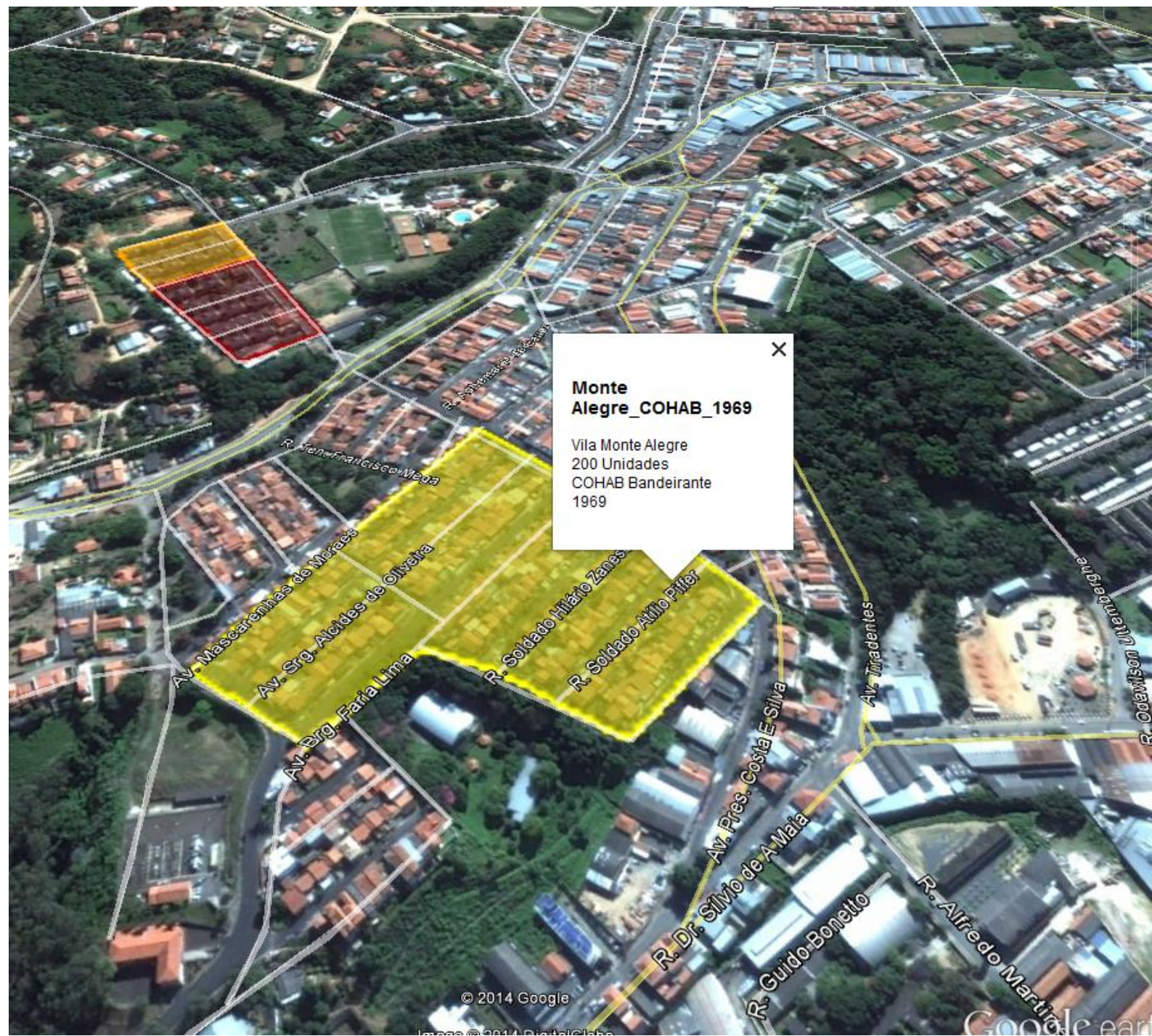

Fonte da imagem: mapa do Google Earth (acesso em 04/2014, data da imagem: 31/07/2013) com a delimitação do perímetro do conjunto e as informações elaboradas pela autora.

Embora nos procedimentos metodológicos adotados para o mapeamento das Habitações de Interesse Social possa haver alguns desvios quanto à precisão dos limites dos conjuntos habitacionais, o método garante que a dimensão deles está bastante próxima da realidade. Para o presente trabalho, que abrange a análise dos 20 municípios da Região 
Metropolitana de Campinas, identificar a localização e a dimensão dos conjuntos é o mais relevante, portanto, possíveis diferenças em relação aos perímetros das HIS não representam prejuízo às análises urbanas e metropolitanas realizadas.

A seguir, apresenta-se o quadro com o detalhamento de como a localização dos conjuntos foi fornecida em cada município e o método utilizado para realizar o mapeamento, onde se pode perceber a diversidade de formas em que as informações foram fornecidas.

Quadro 6 - Material fornecido pelas instituições para o mapeamento das HIS em cada município da RMC (1964-2014)

\begin{tabular}{|c|c|}
\hline Município & Material utilizado no mapeamento \\
\hline Americana & $\begin{array}{l}\text { A localização dos conjuntos de HIS foi fornecida pela prefeitura de forma } \\
\text { pontual em mapa (arquivo tipo } d w g \text { ). Utilizando-se a metodologia descrita, } \\
\text { foi delimitado o perímetro e, quando havia dúvidas, o desenho foi remetido } \\
\text { à Secretaria de Habitação para confirmação e, em alguns casos, quando } \\
\text { não havia desenhos no arquivo, o secretário (que trabalha há } 35 \text { anos no } \\
\text { município) desenhou à mão a delimitação de alguns empreendimentos. }\end{array}$ \\
\hline Artur Nogueira & $\begin{array}{l}\text { O setor de cadastro da prefeitura forneceu plantas (arquivos tipo } p d f \text { ) de } \\
\text { cada conjunto de HIS - Habitação de Interesse Social, pois mesmo os } \\
\text { conjuntos antigos tiveram suas plantas digitalizadas por esse setor. }\end{array}$ \\
\hline & $\begin{array}{l}\text { No caso de Campinas, as informações sobre as localizações foram } \\
\text { fornecidas de diferentes formas e por diferentes órgãos: } \\
\text { I) sobre os empreendimentos da CDHU, o técnico da Companhia desenhou } \\
\text { à mão, em um mapa, a localização de cada conjunto; } \\
\text { II) no caso da COHAB, para a maioria dos conjuntos, foi fornecido um } \\
\text { mapa (arquivo tipo } d w g \text { ) com a localização dos conjuntos, e para aqueles } \\
\text { que não constavam no desenho, foram realizadas visitas à COHAB } \\
\text { Campinas, sendo que a localização foi fornecida ou por meio de desenho à } \\
\text { mão, ou desenho individual em CAD, ou fotografia da planta de aprovação; } \\
\text { III) no caso dos empreendimentos MCMV, a localização da faixa } 1 \text { foi } \\
\text { fornecida de forma pontual pela Secretaria de Habitação e foi utilizada a } \\
\text { metodologia para a delimitação dos perímetros. Para as faixas II e III, foi } \\
\text { fornecido o endereço pela Caixa Econômica Federal e também foi utilizado } \\
\text { o trabalho de Pesquisa da Rede Cidade e Moradia (FERRAMENTAS [...], } \\
\text { 2014). Então, por meio da metodologia descrita, foi marcado um possível } \\
\text { perímetro, o número de unidades foi conferido e, em alguns casos, quando } \\
\text { havia divergências ao checar o perímetro, foi utilizado o número de quadra } \\
\text { (fornecido pelo arquivo da pesquisa da Rede Cidade e Moradia } \\
\text { (FERRAMENTAS [...], 2014), que por sua vez, foi realizada a partir de dados } \\
\text { da CAIXA), e, assim, ao checar com a planta de quadras do município, o } \\
\text { perímetro foi delimitado; } \\
\text { IV) para os conjuntos realizados por meio do PAR, o endereço foi fornecido } \\
\text { pela Caixa Econômica Federal e, a partir dele, utilizou-se da metodologia } \\
\text { para o desenho dos perímetros. } \\
\text { Ressalta-se que nos seguintes casos foi necessária uma visita ao local para } \\
\text { ajustar a delimitação do perímetro: Res. São Bernardo Gleba 10A (2014), } \\
\text { Águas de Lindóia (2014), Res. Águas Belas (2014), Res. Água Doce (2014), } \\
\text { Res. Águas de Limeira (2014), Res. Águas da Serra (2014) e Res. Água } \\
\text { Branca (2014). }\end{array}$ \\
\hline
\end{tabular}




\begin{tabular}{|c|c|}
\hline Município & Material utilizado no mapeamento \\
\hline Cosmópolis & $\begin{array}{l}\text { Em Cosmópolis, foi fornecido pela Secretaria de Planejamento um mapa } \\
\text { (arquivo tipo } d w g \text { ) com as localizações dos loteamentos realizados no } \\
\text { município. Em alguns casos, quando o conjunto de Habitação de Interesse } \\
\text { Social não correspondia ao loteamento, foi utilizada a metodologia para } \\
\text { mapear de forma precisa o perímetro de cada HIS. }\end{array}$ \\
\hline & $\begin{array}{l}\text { Os técnicos municipais localizaram o mapeamento a partir de foto aérea } \\
\text { (Google Earth). }\end{array}$ \\
\hline Holambra & $\begin{array}{l}\text { O técnico municipal descreveu de forma detalhada, em entrevista, quais } \\
\text { ruas que delimitavam o perímetro dos conjuntos de HIS e, assim, a autora } \\
\text { desenhou o perímetro dos conjuntos e enviou por e-mail para a Secretaria } \\
\text { de Habitação para conferência. }\end{array}$ \\
\hline Hortolândia & $\begin{array}{l}\text { O técnico municipal forneceu (a partir de solicitação por meio de protocolo) } \\
\text { um mapa impresso com a localização pontual de todos os conjuntos de HIS. } \\
\text { Para os empreendimentos MCMV (faixas } 2 \text { e } 3 \text { ) e os conjuntos realizados } \\
\text { pelo PAR, os endereços foram fornecidos pela CEF. A partir do material, foi } \\
\text { utilizada a metodologia desenvolvida no trabalho para a delimitação dos } \\
\text { perímetros. Para a localização do Residencial Novo Cambuí, entrou-se em } \\
\text { contato diretamente com a Construtora (SEGA), pois não era possível } \\
\text { identificá-lo por meio da foto aérea. }\end{array}$ \\
\hline Indaiatuba & $\begin{array}{l}\text { Para a maioria dos conjuntos de HIS, foi fornecido o nome de uma rua e, a } \\
\text { partir dele, utilizou-se a metodologia para a delimitação do perímetro. A } \\
\text { disponibilização das plantas dos loteamentos da cidade no site da prefeitura } \\
\text { municipal facilitou a utilização da metodologia. Quanto ao Jd. Colibris, foi } \\
\text { fornecida uma planta (em arquivo tipo } d w g \text { ) pela prefeitura (pois nem todas } \\
\text { as casas do loteamento pertencem ao conjunto). Quanto ao conjunto } \\
\text { Juscelino Kubtischek (1988 e } 1990 \text { ), foi fornecida a localização em planta } \\
\text { aérea por técnico da prefeitura. }\end{array}$ \\
\hline Itatiba & $\begin{array}{l}\text { A localização foi fornecida em arquivo Google Earth (arquivo tipo } \mathrm{kmz} \text { ) por } \\
\text { técnico da prefeitura, sendo também checadas as localizações no trabalho } \\
\text { final de graduação de Branco (2013). Para as faixas } 2 \text { e } 3 \text { do MCMV, o } \\
\text { endereço foi fornecido pela CEF e foi utilizada a metodologia para a } \\
\text { delimitação dos perímetros. }\end{array}$ \\
\hline Jaguariúna & $\begin{array}{l}\text { Para a localização de alguns conjuntos de HIS, foi fornecido o nome de uma } \\
\text { rua e aplicada a metodologia para delimitação do perímetro. No entanto, } \\
\text { para a maioria dos conjuntos, foi fornecida uma imagem (arquivo jpg) } \\
\text { gerada a partir do Google Earth, com a delimitação do perímetro da HIS } \\
\text { demarcada por técnico da Secretaria de Planejamento de Jaguariúna. }\end{array}$ \\
\hline Monte Mor & $\begin{array}{l}\text { A Secretaria de Obras forneceu a planta urbanística (arquivo tipo jpg) de } \\
\text { cada conjunto de Habitação de Interesse Social (HIS). }\end{array}$ \\
\hline Morungaba & $\begin{array}{l}\text { Para o conjunto José Consolim (1978), foi fornecido o nome de uma rua; } \\
\text { para os outros três empreendimentos, a Secretaria de Obras forneceu a } \\
\text { localização aproximada (em arquivo pdf). Para todos os conjuntos de HIS, } \\
\text { foi aplicada a metodologia desenvolvida para a delimitação do perímetro. }\end{array}$ \\
\hline Nova Odessa & $\begin{array}{l}\text { A Diretoria de Habitação forneceu um mapa (em arquivo tipo } d w g \text { ) que foi } \\
\text { elaborado para o PLHIS e contém a localização dos conjuntos de HIS, com } \\
\text { exceção de dois: Jardim Fibra (2013) e Conjunto Residencial Maria } \\
\text { Raposeiro Azenha (1978). Para esses dois, foi fornecida a imagem (arquivo } \\
\text { tipo jpg) de uma planta com a localização aproximada dos } \\
\text { empreendimentos, e os perímetros deles foram demarcados a partir da } \\
\text { metodologia desenvolvida. }\end{array}$ \\
\hline
\end{tabular}




\begin{tabular}{|c|c|}
\hline Município & Material utilizado no mapeamento \\
\hline Paulínia & $\begin{array}{l}\text { O técnico da Secretaria de Planejamento forneceu uma planta urbanística } \\
\text { dos conjuntos de HIS realizados no município, exceto do Serra Azul. Nesse } \\
\text { caso, algumas unidades de um loteamento particular foram desapropriadas, } \\
\text { portanto, elas foram mapeadas a partir da leitura dos seguintes decretos } \\
\text { municipais de desapropriação: } 5.339,5.311,5.272 \text { e } 5.271 \text { do ano de } 2005 \text {. } \\
\text { Por meio dos decretos, foi possível reconhecer os números de quadra e de } \\
\text { lote desapropriados, e eles foram então identificados em um mapa do } \\
\text { loteamento fornecido pela Secretaria de Planejamento do município. }\end{array}$ \\
\hline Pedreira & $\begin{array}{l}\text { Dos dezessete conjuntos de HIS realizados, em doze a localização ocorreu } \\
\text { por meio do nome de uma rua e uso da metodologia descrita. Para os } \\
\text { outros cinco - Aparecida Inês Ceconcello, Triunfo Maia, Jd. Marajoara, Pq. } \\
\text { dos Jequetibás e Shigueo Kobayashi - a Secretaria Municipal de Promoção } \\
\text { Social forneceu a localização do perímetro em foto aérea. }\end{array}$ \\
\hline $\begin{array}{l}\text { Santa Bárbara } \\
\text { d'Oeste }\end{array}$ & $\begin{array}{l}\text { O técnico da Secretaria de Planejamento forneceu planta em arquivo tipo } \\
\text { pdf (gerada a partir de arquivo } d w g \text { ) com a localização de todos os } \\
\text { conjuntos de Habitação de Interesse Social (HIS). }\end{array}$ \\
\hline $\begin{array}{l}\text { Santo Antônio } \\
\text { de Posse }\end{array}$ & $\begin{array}{l}\text { Para o conjunto Vila Esperança, o Bela Vista I e II, o Condomínio Azaléia } \\
\text { (MCMV) e os conjuntos da CDHU, o técnico da Secretaria de Habitação } \\
\text { desenhou à mão as localizações, e elas foram fotografadas, quando houve } \\
\text { a visita ao município. Posteriormente, foram enviadas as localizações (em } \\
\text { arquivo pdf) dos conjuntos Novo Horizonte } 1 \text { e } 2 \text {. }\end{array}$ \\
\hline Sumaré & $\begin{array}{l}\text { A Secretaria de Habitação do município forneceu o nome de uma rua para } \\
\text { cada um dos dez conjuntos de HIS. Para outros oito, a Secretaria } \\
\text { disponibilizou uma planta (em arquivo pdff) com a localização de forma } \\
\text { pontual dos seguintes empreendimentos: Núcleo CECAP, Pq Nova Veneza - } \\
\text { INOCOOP, Residencial Recanto das Árvores, Portal Bordon, Conj. Hab } \\
\text { Amabile e Nobile, Jardim das Estâncias e Emílio Bosco. Para os conjuntos } \\
\text { das faixas } 2 \text { e } 3 \text { do MCMV, o endereço foi fornecido pela CEF. A partir das } \\
\text { três bases pontuais de localização, utilizou-se a metodologia para o } \\
\text { mapeamento dos perímetros dos conjuntos de HIS. }\end{array}$ \\
\hline Valinhos & $\begin{array}{l}\text { Foi utilizado o método descrito; as HIS foram mapeadas a partir do nome } \\
\text { de uma rua fornecida pela Secretaria de Habitação do municíio. Nos } \\
\text { seguintes casos, houve dúvidas e os desenhos de implantação foram } \\
\text { solicitados à Secretaria: Jd. Novo Mundo I (1976), Jd. Novo Mundo II } \\
\text { (1979), Jd. Bom Retiro II (1977), Jd. Do Lago (1986), Jd. Universo I } \\
\text { (1993), Jd. Universo II (1997) e Jd. Morada do Sol (2010). Nos conjuntos } \\
\text { realizados pelo Programa Minha Casa Minha Vida (faixas } 2 \text { e 3), as } \\
\text { informações foram fornecidas pela CEF, e para o empreendimento "Mais } \\
\text { Campos Sales", os dados foram obtidos na pesquisa (FERRAMENTAS [...], } \\
\text { 2014), com exceção da data de entrega, fornecida pela Secretaria de } \\
\text { Habitação do município. }\end{array}$ \\
\hline Vinhedo & $\begin{array}{l}\text { Foi utilizado o método descrito; as HIS foram mapeadas a partir do nome } \\
\text { de uma rua fornecida pela Secretaria de Habitação, exceto nos seguintes } \\
\text { casos, para os quais foi fornecido o perímetro (em foto aérea) pelo diretor } \\
\text { de Habitação: Jd. Bela Vista ( } 228 \text { casas), Jd. Bela Vista ( } 36 \text { casas), Jd. } \\
\text { Eldorado, Bela Vista II, São Thomé (100 lotes), Vila Junqueira, Vida Nova } \\
\text { III, São Thomé ( } 37 \text { casas) e Núcleo Habitacional Maria Helena B. Soldeira. }\end{array}$ \\
\hline
\end{tabular}


Cabe ressaltar que, apesar das dificuldades relativas ao mapeamento, $98 \%$ dos conjuntos levantados foram mapeados ou $99,7 \%$ das unidades habitacionais, como se pode observar na Tabela 29 (p. 136). O percentual de unidades habitacionais mapeadas é maior do que o número de conjuntos, porque a dimensão da maioria dos conjuntos não mapeada é muito pequena, pois, conforme a metodologia, não foram mapeados os conjuntos de Habitação de Interesse Social com menos de dez unidades. Além desses pequenos conjuntos, alguns não foram mapeados devido à falta de informação ou por as unidades estarem dispersas em várias áreas da cidade, conforme se pode observar na coluna Observações das tabelas de levantamento dos municípios (p. 76 a p. 113).

Tabela 29 - Quantidade de conjuntos de HIS e de unidades habitacionais de interesse social levantados e mapeados na pesquisa

\begin{tabular}{|c|c|c|c|c|c|c|}
\hline Municípios & \begin{tabular}{|c|} 
No de \\
conjuntos \\
levantados
\end{tabular} & $\begin{array}{c}\mathrm{N}^{\circ} \text { de } \\
\text { conjuntos } \\
\text { mapeados }\end{array}$ & $\begin{array}{c}\text { Porcentagem } \\
\text { de conjuntos } \\
\text { mapeados }\end{array}$ & \begin{tabular}{|c|}
$N^{0}$ de \\
unidades \\
habitacionais \\
levantadas \\
\end{tabular} & \begin{tabular}{|c|}
$N^{0}$ de \\
unidades \\
habitacionais \\
mapeadas \\
\end{tabular} & $\begin{array}{c}\text { Porcentagem } \\
\text { de unidades } \\
\text { habitacionais } \\
\text { mapeadas } \\
\end{array}$ \\
\hline Americana & 62 & 62 & $100,0 \%$ & 15.144 & 15.144 & $100,0 \%$ \\
\hline Artur Nogueira & 12 & 12 & $100,0 \%$ & 2.405 & 2.405 & $100,0 \%$ \\
\hline Campinas & 157 & 151 & $96,2 \%$ & 59.681 & 59.348 & $99,4 \%$ \\
\hline Cosmópolis & 14 & 13 & $92,9 \%$ & 3.404 & 3.396 & $99,8 \%$ \\
\hline Eng. Coelho & 2 & 2 & $100,0 \%$ & 465 & 465 & $100,0 \%$ \\
\hline Holambra & 2 & 2 & $100,0 \%$ & 362 & 362 & $100,0 \%$ \\
\hline Hortolândia & 32 & 32 & $100,0 \%$ & 6.425 & 6.425 & $100,0 \%$ \\
\hline Indaiatuba & 29 & 29 & $100,0 \%$ & 7.140 & 7.140 & $100,0 \%$ \\
\hline Itatiba & 18 & 18 & $100,0 \%$ & 5.143 & 5.143 & $100,0 \%$ \\
\hline Jaguariúna & 15 & 15 & $100,0 \%$ & 3.890 & 3.890 & $100,0 \%$ \\
\hline Monte Mor & 3 & 3 & $100,0 \%$ & 557 & 557 & $100,0 \%$ \\
\hline Morungaba & 4 & 4 & $100,0 \%$ & 535 & 535 & $100,0 \%$ \\
\hline Nova Odessa & 11 & 11 & $100,0 \%$ & 3.531 & 3.531 & $100,0 \%$ \\
\hline Paulínia & 24 & 24 & $100,0 \%$ & 8.658 & 8.658 & $100,0 \%$ \\
\hline Pedreira & 23 & 23 & $100,0 \%$ & 2.157 & 2.106 & $97,6 \%$ \\
\hline $\begin{array}{l}\text { Santa Bárbara } \\
\text { d'Oeste }\end{array}$ & 16 & 16 & $100,0 \%$ & 6.155 & 6.155 & $100,0 \%$ \\
\hline $\begin{array}{l}\text { Santo Antônio } \\
\text { de Posse }\end{array}$ & 7 & 7 & $100,0 \%$ & 1.092 & 1.092 & $100,0 \%$ \\
\hline Sumaré & 27 & 25 & $92,6 \%$ & 12.183 & 12.119 & $99,5 \%$ \\
\hline Valinhos & 27 & 26 & $96,3 \%$ & 7.151 & 7.144 & $99,9 \%$ \\
\hline Vinhedo & 19 & 19 & $100,0 \%$ & 3.623 & 3.623 & $100,0 \%$ \\
\hline Total & 504 & 494 & $98,0 \%$ & 149.701 & 149.238 & $99,7 \%$ \\
\hline
\end{tabular}

Fonte: dados relacionados pela autora a partir do levantamento empírico da tese. 


\subsection{Habitações de Interesse Social e estruturação urbana}

Esta sessão apresenta o mapeamento das Habitações de Interesse Social realizadas em cada município da Região Metropolitana de Campinas, em duas escalas: na municipal, considerando cada município individualmente, e na metropolitana, considerando a Região Metropolitana como unidade.

Isso permite a percepção das dinâmicas de cada município e destas com relação ao conjunto da região, permitindo que se observe essa dupla relação, segundo os diferentes vetores de expansão urbana.

\subsubsection{A escala municipal: implantação das HIS no tecido urbano}

Os municípios da Região Metropolitana de Campinas (RMC) serão apresentados em cinco grupos, a partir das tipologias de implantação de seus conjuntos de Habitação de Interesse Social. Cabe lembrar que esta análise foi realizada a partir dos dados coletados nos municípios, na CDHU, na CEF e na COHAB Campinas, e os mapeamentos foram realizados conforme metodologia descrita na primeira parte deste capítulo (p. 126 e seguintes).

A despeito da importância da discussão regional da morfologia urbana, esta primeira análise considerou os conjuntos implantados no perímetro de cada município, de modo que fosse possível discutir os padrões de localização desses conjuntos, sendo que, posteriormente, a implantação dos conjuntos será abordada na Região Metropolitana de Campinas como um todo.

Observam-se a seguir a classificação e a análise desses cinco grupos e, na sequência, imagens do mapeamento das Habitações de Interesse Social nos municípios correspondentes. Essas imagens foram selecionadas a partir do limite de cada município (destacado por meio de uma linha na cor vermelha). Em alguns casos, onde a área urbanizada era muito pequena em relação ao perímetro municipal, houve dificuldade na leitura dos mapas, portanto, foram apresentados mapas em duas escalas: um com o enquadramento do limite municipal e outro com uma aproximação da área urbanizada, de modo que fosse possível observar melhor a implantação dos conjuntos. Eles apresentam cores diferenciadas, conforme as décadas de implantação ou agente financeiro: após 1964 e década de 1970 (cor: amarela); década de 1980 (cor: laranja); década de 1990 (cor: vermelha escuro); a partir de 2000 (cor: magenta); e conjuntos realizados no último período (a partir de 2000), entretanto, realizados por meio do MCMV - faixas 2 e 3 (cor: azul). Eles 
são voltados para outra faixa de renda ${ }^{107}$ e realizados por empresas privadas ${ }^{108}$, apesar do financiamento público do governo federal. Acredita-se que esses fatores reflitam nas características de localização desses conjuntos, portanto, optou-se por destacá-los com uma cor diferente do período.

\section{Grupo I}

Relacionam-se aqui os municípios que apresentam os conjuntos de Habitação de Interesse Social localizados de forma periférica, nas bordas do tecido urbano e com uma área de concentração desses conjuntos, o que se observa em: Americana, Campinas, Itatiba, Santa Bárbara d'Oeste e Sumaré.

Nesses cinco municípios, podem-se observar conjuntos de HIS realizados em todos os períodos, desde 1964 até 2014, conforme mapas de implantação apresentados a seguir (p. 140 a 145). As áreas urbanizadas, embora apresentem características e tamanhos distintos, assemelham-se quanto à localização dos conjuntos de Habitação de Interesse Social, pois a maioria deles localiza-se nas bordas dessas áreas. As poucas exceções são os conjuntos destacados na cor amarela, ou seja, aqueles realizados entre 1964 e 1979, pois, quando foram feitos, também eram distantes das áreas centrais, providas de infraestrutura e serviços urbanos, mas, com o crescimento urbano, essas áreas tornaram-se mais inseridas no tecido urbano. Cabe lembrar que isso ocorre em alguns conjuntos de Itatiba, Campinas e Sumaré, entretanto, em Americana e em Santa Bárbara d'Oeste, as HIS realizadas em todos os períodos estão em áreas periféricas. Outra exceção quanto à localização são os conjuntos das faixas 2 e 3 do Minha Casa Minha Vida em Americana, Campinas e Santa Bárbara d'Oeste, que apresentam uma localização um pouco mais inserida no tecido urbano.

Outra característica da localização é que nesses quatro municípios há locais de concentração desses empreendimentos, como se pode observar nos mapas dos municípios onde foram destacados por meio de círculos (na cor branca) esses locais de aglomeração dos conjuntos de Habitação de Interesse Social. O preço da terra é o grande determinante das localizações das HIS, como discutido em diversas obras por Maricato, Bonduki e Whitaker. Nos locais de concentração, há empreendimentos realizados em diversos períodos,

\footnotetext{
107 O Programa Minha Casa Minha Vida constituiu-se em faixas: de 0 a 3 salários mínimos - faixa 1, de 3 a 6 SM - faixa 2 e de 6 a 10 SM - faixa 3. Os valores fixados para as faixas a partir dos salários mínimos foram ajustados durante a realização do programa: a faixa 1 passou de $R \$ 1.395,00$ para $R \$ 1.600,00$; a faixa 2 passou de $R \$$ $2.790,00$ para $R \$ 3.275,00$ e a faixa 3 passou de $R \$ 4.650,00$ para $R \$ 5.000,00$.

108 Conforme se pode observar na coluna observações das tabelas dos conjuntos de HIS dos municípios, os empreendimentos MCMV das faixas 2 e 3 foram realizados por empresas privadas e não atendem aos cadastros municipais, eles são independentes das políticas ou planos municipais. O repasse de verba ocorre diretamente entre empresa privada (construtora) e o governo federal (Caixa Econômica Federal).
} 
pois se acredita que a implantação dos primeiros conjuntos "determinou" um certo valor da terra, o que propiciou que outros conjuntos de HIS fossem implantados em áreas bastante próximas, muitas vezes, adjacentes (ver Mapa 7 a Mapa 12, p. 140 a 145).

Em Campinas, devido à dimensão do município, há algumas peculiaridades, pois embora as HIS estejam, como nos outros municípios, dispersas pelo tecido urbano, há diversas áreas de concentração, entretanto todas essas concentrações localizam-se no vetor sudoeste da cidade, nas franjas da área urbanizada, conforme se observar no Mapa 8 ( $p$. 141). Ao se considerar a rodovia Dom Pedro I e a rodovia Anhanguera como delimitadoras de uma área, como demarcadoras de uma região, pode-se notar que todos os conjuntos pós década de 1980 estão localizados externamente a essa delimitação, tornando evidente a segregação desse tipo de ocupação. Dentro desse perímetro delimitado pelas rodovias, as exceções são os conjuntos das faixas 2 e 3 do Minha Casa Minha Vida e alguns projetos pequenos realizados na década de 2000 , que são voltados à reurbanização de favelas. 
Mapa 7 - Habitações de Interesse Social produzidas em Americana (1964-2014) - limite municipal

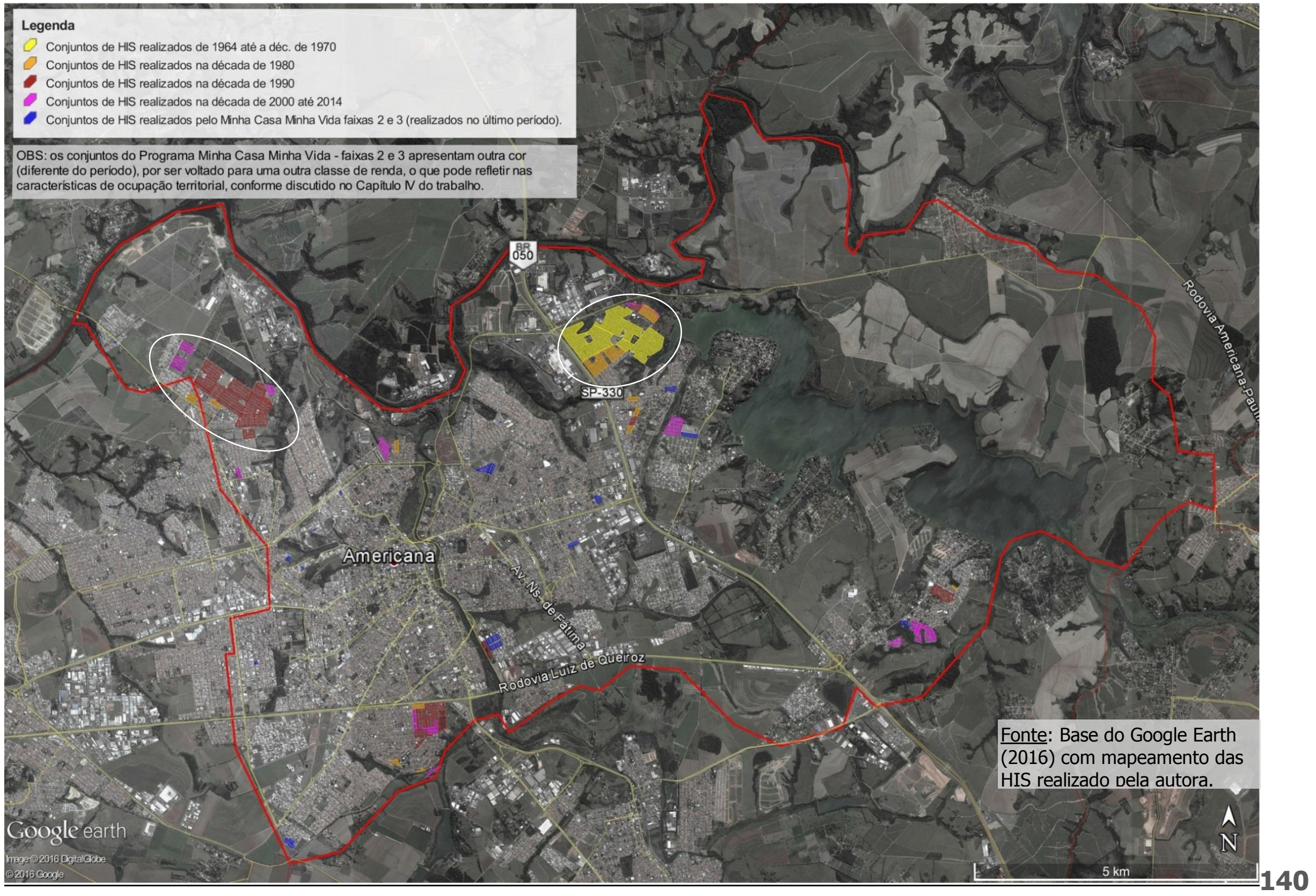


Mapa 8 - Habitações de Interesse Social produzidas em Campinas (1964-2014) - limite municipal

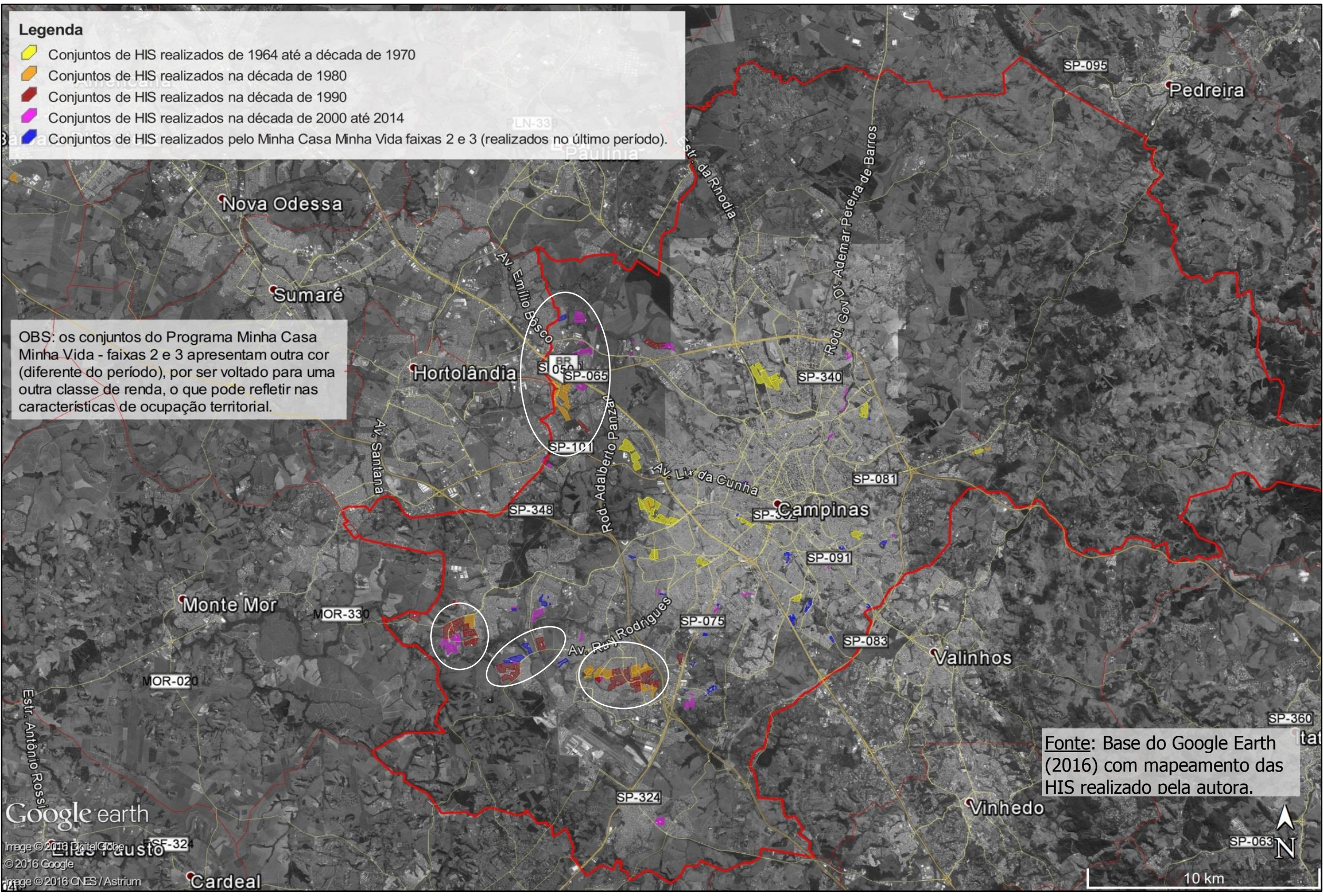


Mapa 9 - Habitações de Interesse Social produzidas em Itatiba (1964-2014) - limite municipal

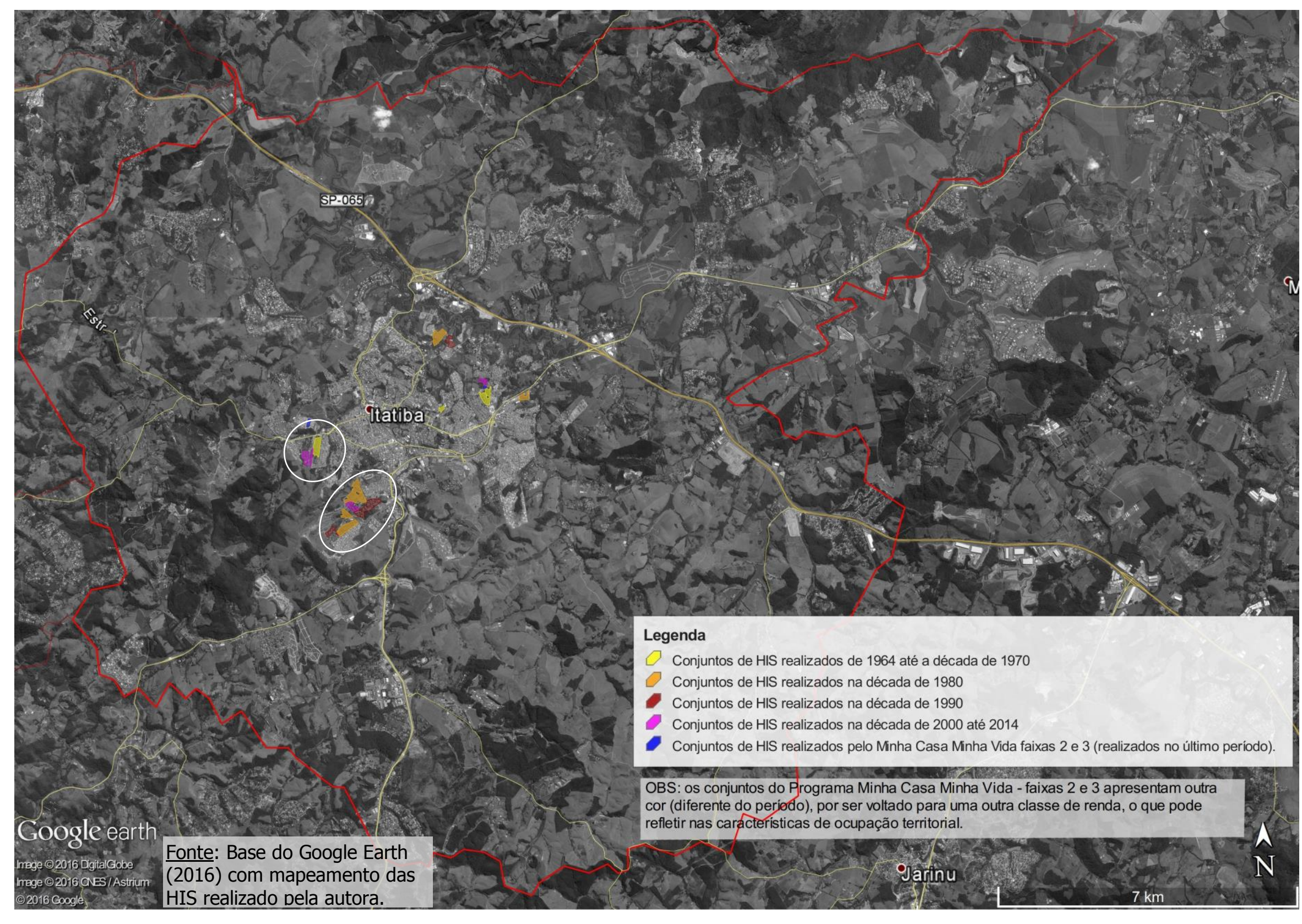


Mapa 10 - Habitações de Interesse Social produzidas em Itatiba (1964-2014) - área urbanizada

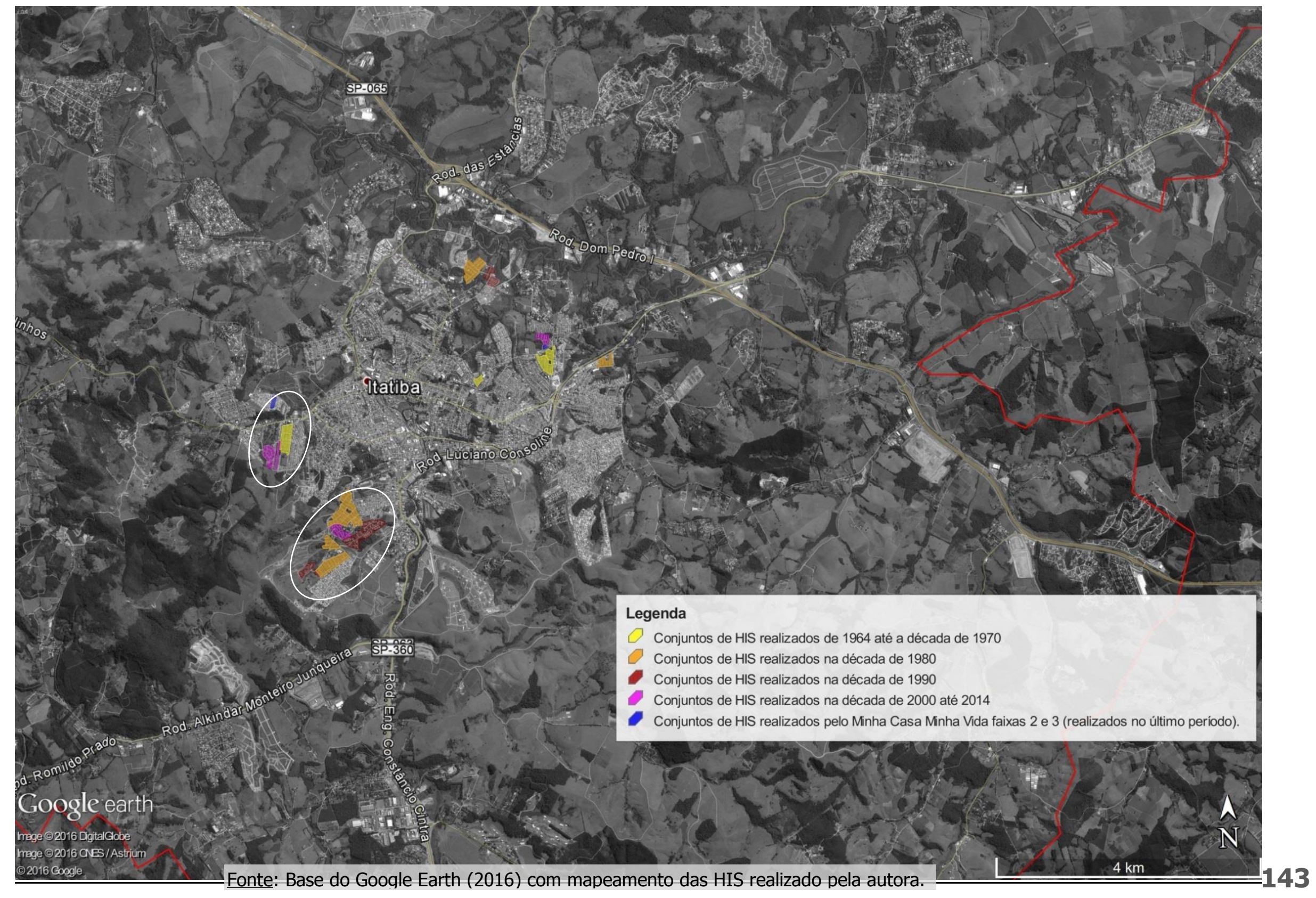


Mapa 11 - Habitações de Interesse Social produzidas em Santa Bárbara d’Oeste (1964-2014) - limite municipal

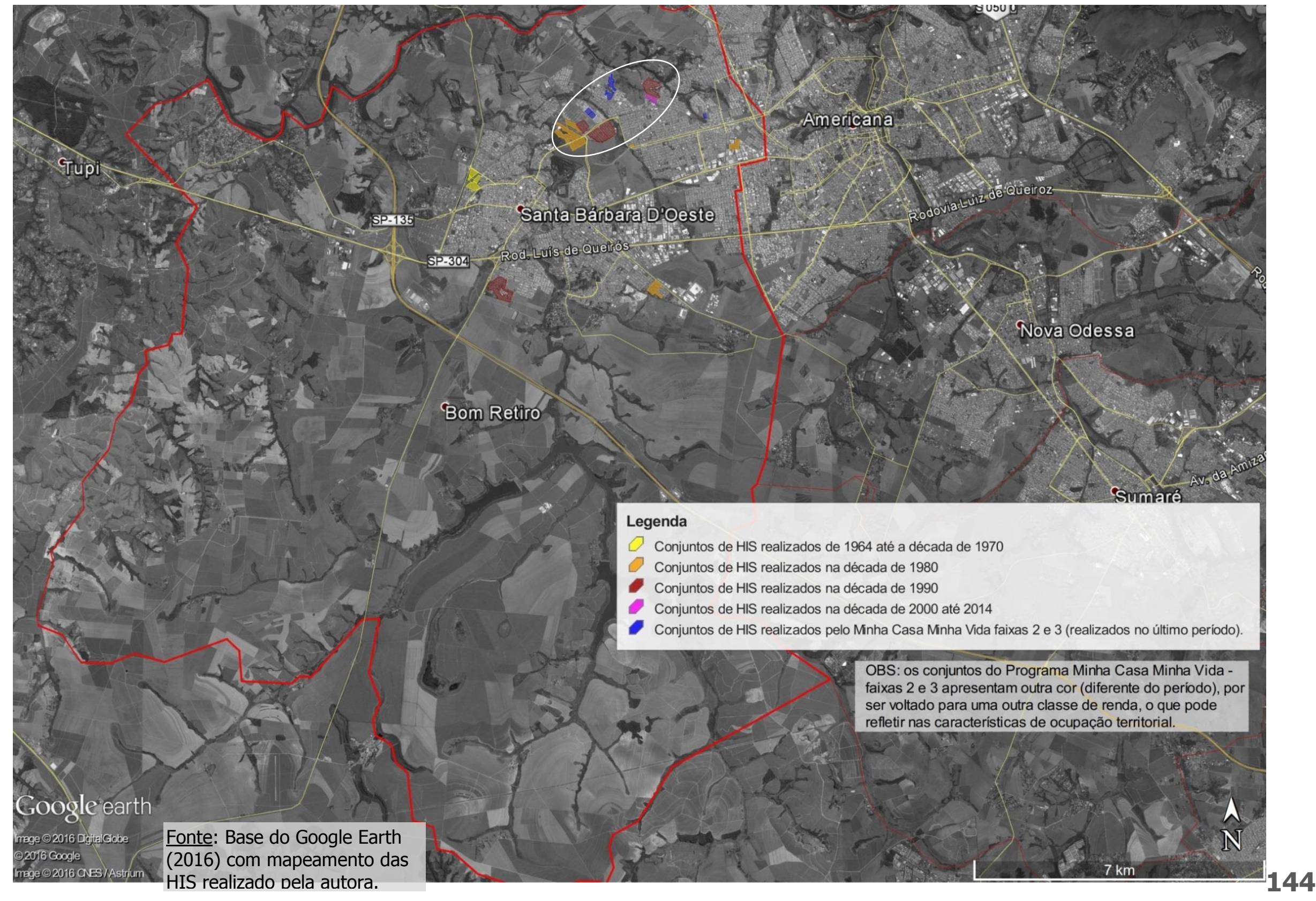


Mapa 12 - Habitações de Interesse Social produzidas em Sumaré (1964-2014) - limite municipal

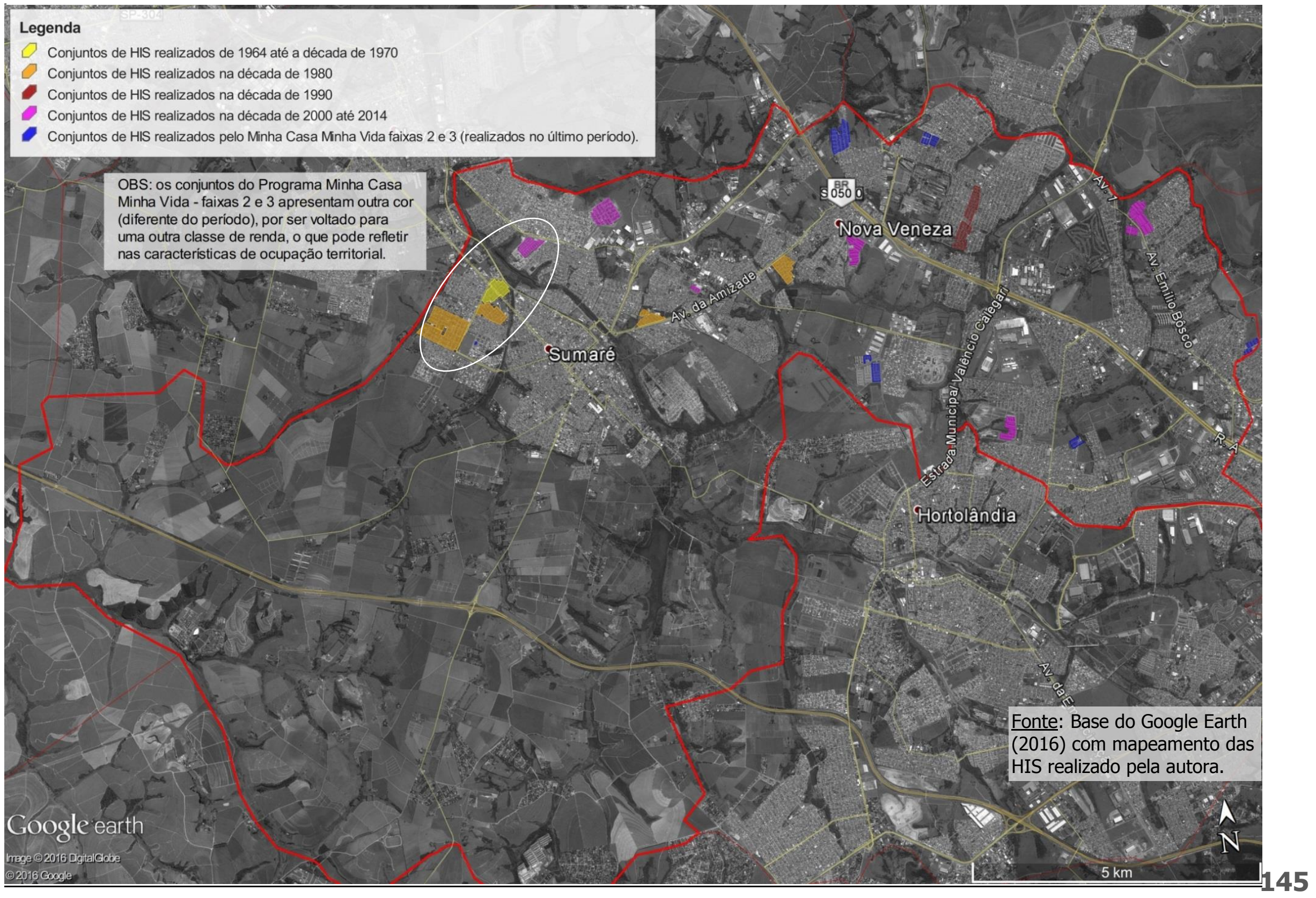




\section{Grupo II}

Apresentam-se aqui os conjuntos de Habitações de Interesse Social que se localizam, assim como no grupo I (p. 138), nas bordas das áreas urbanizadas, entretanto, não apresentam uma área ou vetor de concentração - eles podem ser observados de forma dispersa em várias áreas periféricas da cidade. Essa tipologia de implantação pode-se verificar em Hortolândia, Nova Odessa, Pedreira e Valinhos.

Nesses quatro municípios, pode-se notar que os conjuntos de HIS foram implantados predominantemente nas bordas dos tecidos urbanos, áreas muitas vezes carentes de infraestrutura e serviços. As exceções são os conjuntos das faixas 2 e 3 do Minha Casa Minha Vida, pois, como eles são voltados para outra faixa de renda e realizados por empresas privadas, a lógica de implantação difere dos outros conjuntos. Outros conjuntos que não se localizam nas bordas dos tecidos urbanos são aqueles realizados no primeiro período, entre 1964 e 1979 (demarcados na cor amarela), pois, quando foram implantados, seguiam a mesma lógica de estarem distantes das áreas mais centralizadas, que dispõem de infraestrutura e serviços, mas, com o crescimento urbano, tornaram-se mais inseridos no tecido urbano, o que pode ser observado nos municípios de Pedreira, Valinhos e Nova Odessa.

Em Pedreira, observa-se um tecido urbano bastante espraiado, o que ocorre devido aos acidentes topográficos da área do município. Dessa forma, observam-se os conjuntos de HIS bastante distantes um dos outros, sempre nas áreas limítrofes do tecido urbano. As exceções, como já citado, são os conjuntos do primeiro período - no caso de Pedreira, apenas dois: Monte Alegre, de 1969, e Jardim Triunfo Maia, de 1978 (ver Mapa 15, p. 150). Nova Odessa, assim como Pedreira, é um município pequeno (Mapa 2, p. 33), entretanto, com uma área urbanizada menos espraiada, onde todos os conjuntos estão nas bordas do tecido urbano, conforme Mapa 14 (p. 149).

Em Hortolândia, um município mais recente, fundado em 1991, desmembrado de Sumaré, pode-se observar no Mapa 13 (p. 148) que todos os conjuntos de Habitação de Interesse Social foram realizados no último período. Em relação à forma de ocupação, embora a escala do município seja maior do que em Pedreira e Nova Odessa, trata-se de um município médio (Mapa 2, p. 33), e a forma de ocupação das HIS assemelha-se à de Nova Odessa, com um tecido urbano menos espraiado, de certa forma ordenado pelas vias de conexões à rodovia Anhanguera, e as HIS localizam-se nas áreas periféricas da área urbanizada (ver Mapa 13, p. 148). 
De forma diferente, em Valinhos, um município médio (Mapa 2), podem-se notar alguns conjuntos das faixas 2 e 3 do Minha Casa Minha Vida e outros do primeiro período em área um pouco mais centralizada, embora, como já discutido, a lógica de ocupação territorial das HIS do primeiro período seja a mesma dos mais recentes - os conjuntos foram implantados nas margens da área urbanizada, como se pode observar no Mapa 16, p. 151. 
Mapa 13 - Habitações de Interesse Social produzidas em Hortolândia (1964-2014) - limite municipal

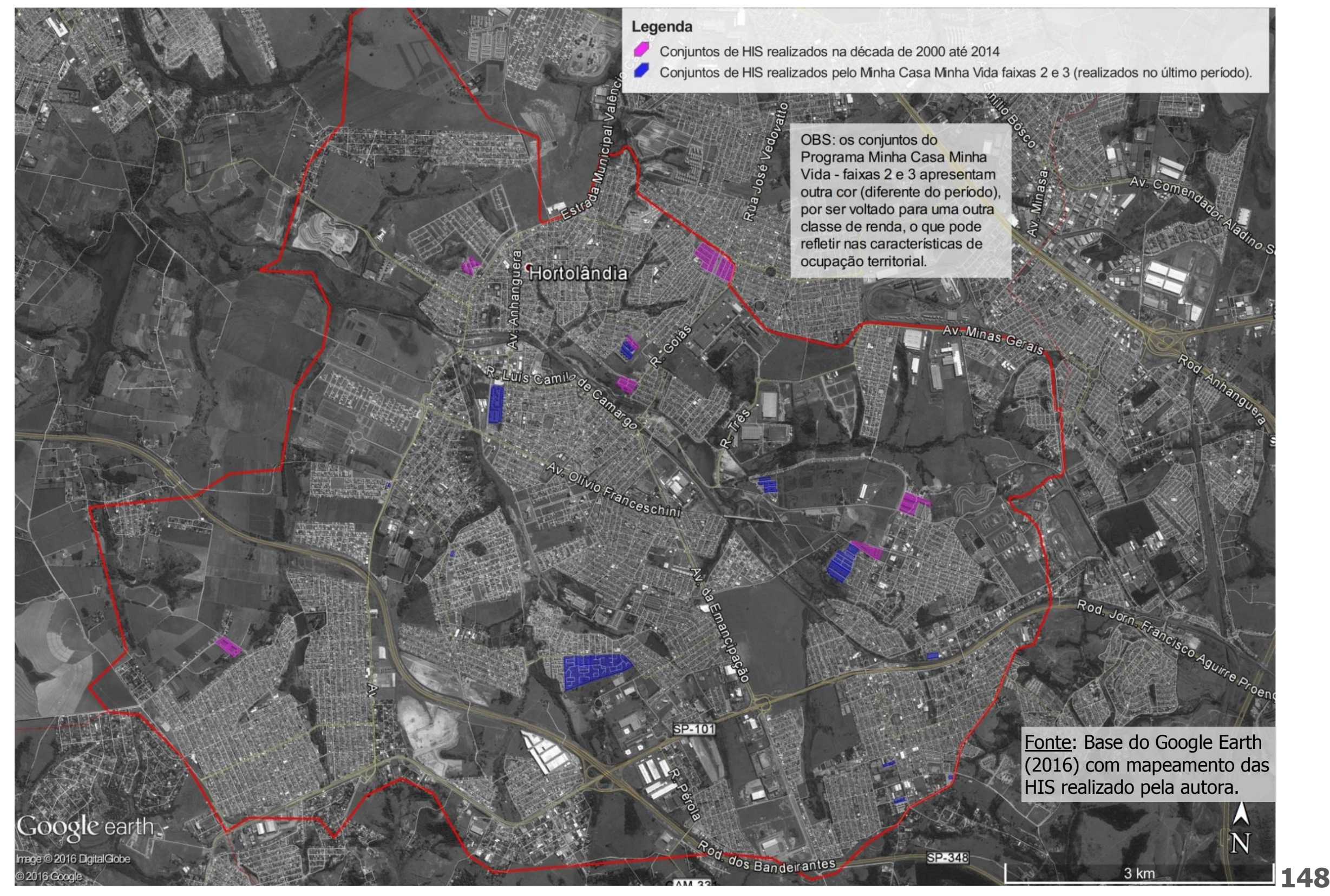


Mapa 14 - Habitações de Interesse Social produzidas em Nova Odessa (1964-2014) - limite municipal

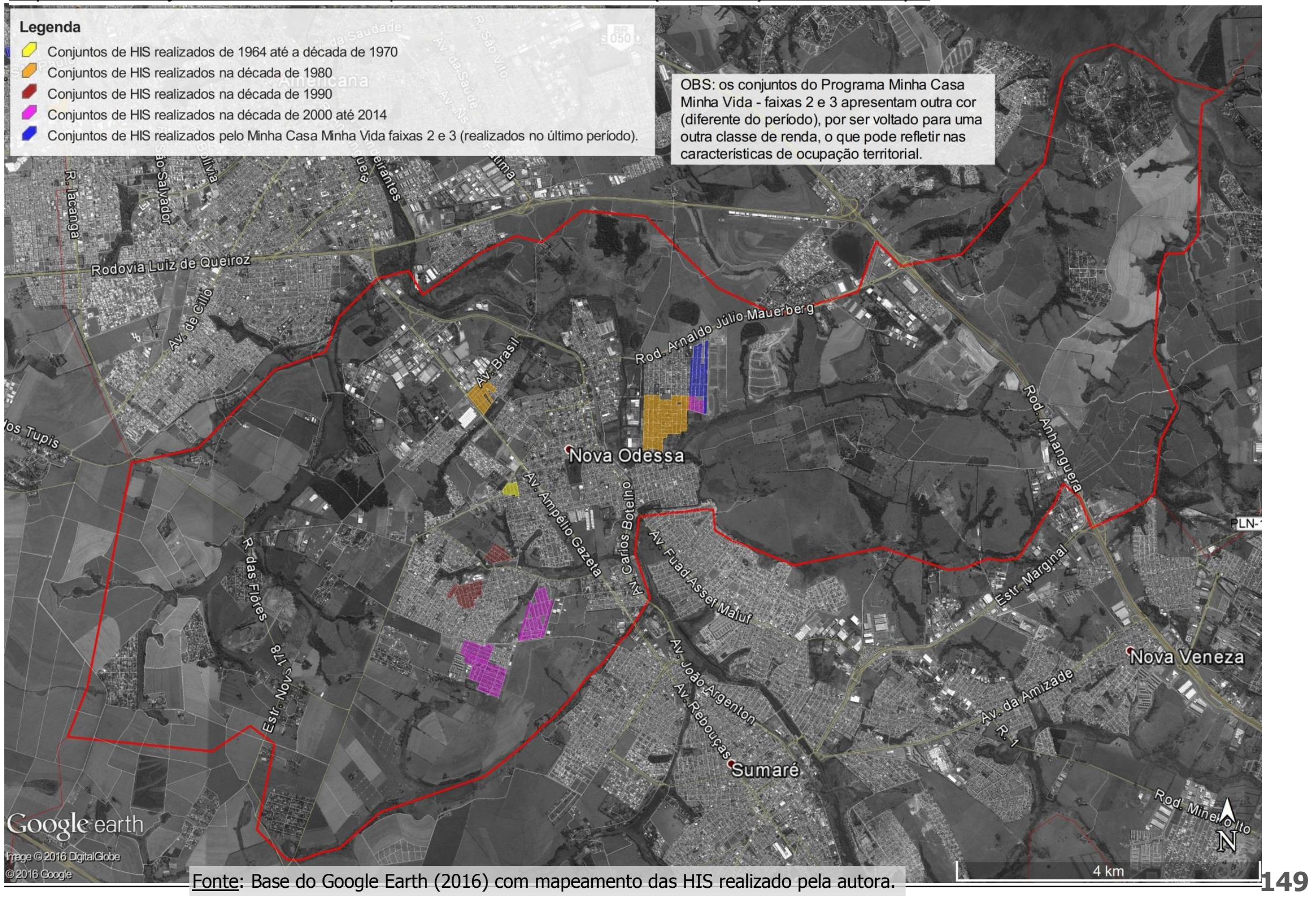


Mapa 15 - Habitações de Interesse Social produzidas em Pedreira (1964-2014) - limite municipal

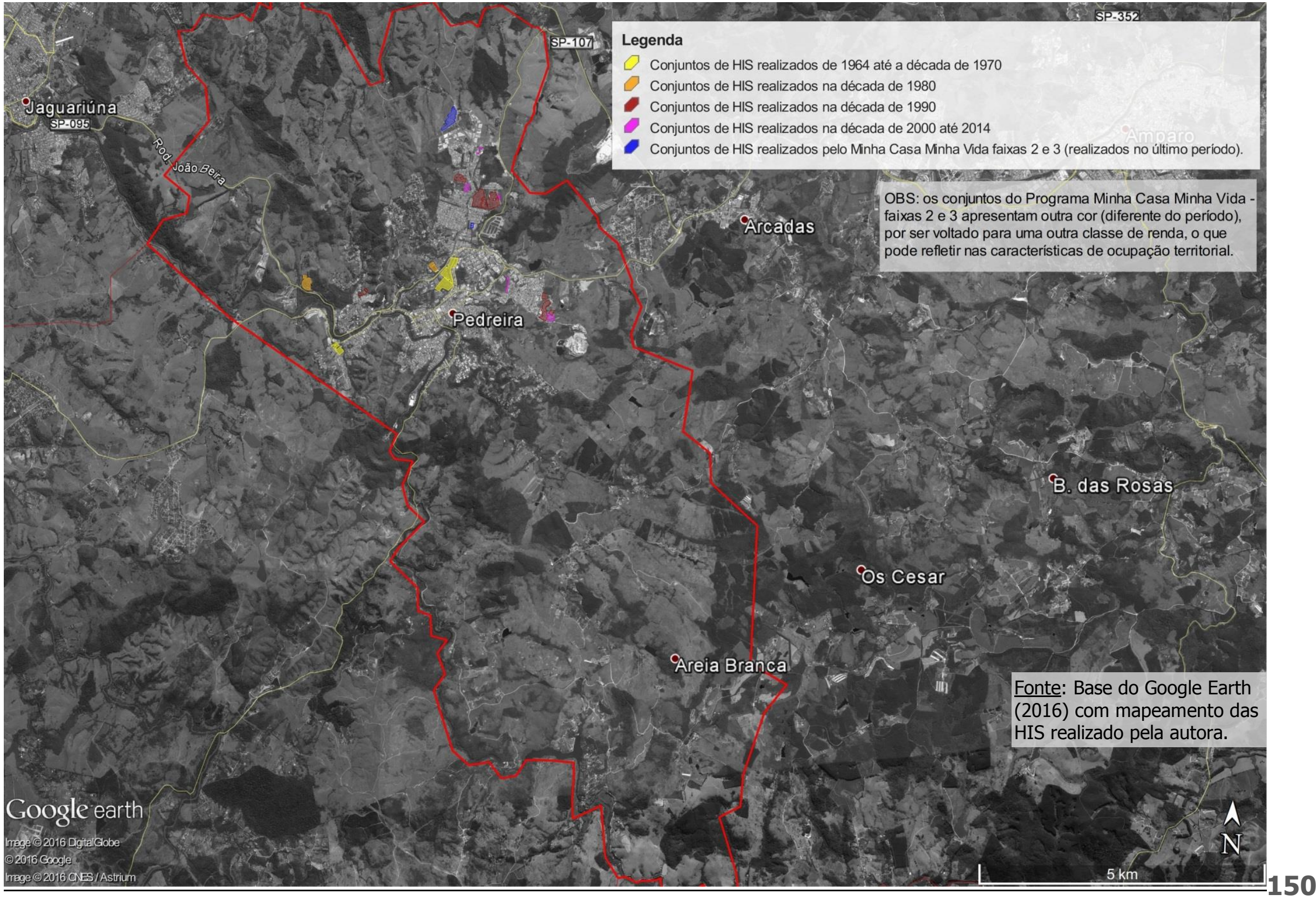


Mapa 16 - Habitações de Interesse Social produzidas em Valinhos (1964-2014) - limite municipal

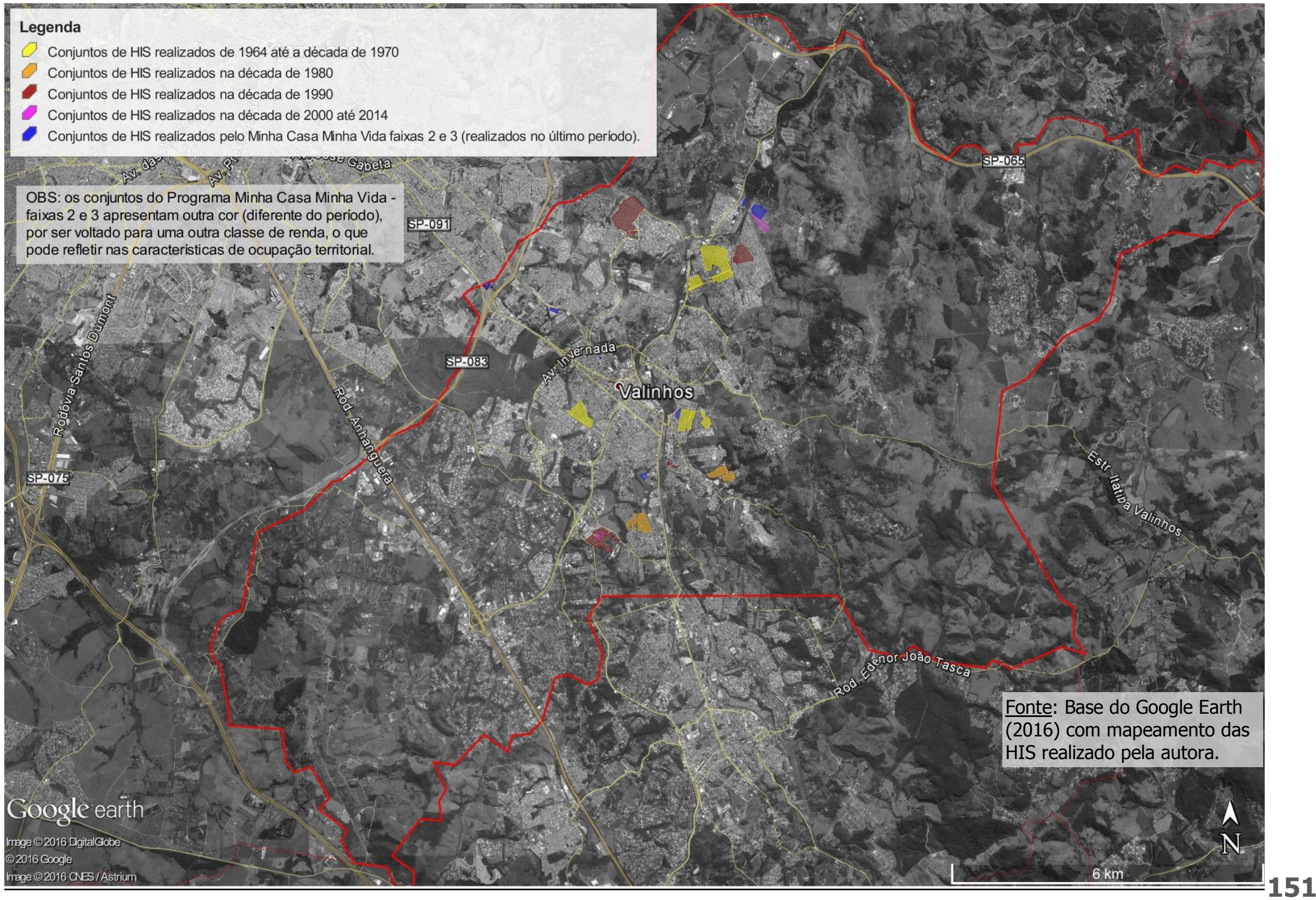




\section{Grupo III}

Constam nesse grupo duas cidades - Vinhedo e Paulínia, em que os conjuntos de Habitação de Interesse Social (HIS) foram implantados em duas áreas específicas da cidade. Percebe-se que nos tecidos urbanos há dois locais voltados a esse tipo de ocupação.

Em Paulínia, pode-se observar no Mapa 17 (p. 153) nitidamente dois eixos de implantação das Habitações de Interesse Social, um a sudoeste, ao longo da Av. Antônio Batista Piva, onde estão situadas habitações de todos os períodos analisados, desde 1970 até 2011. Nota-se que as primeiras HIS implantadas estão mais próximas da área central e nas décadas subsequentes foram realizados novos conjuntos habitacionais ao longo do mesmo eixo, como uma ampliação da mesma lógica de ocupação. Outra área de implantação mais recente pode ser observada a noroeste, ao longo da Av. Fausto Pietrobon, seguindo pela Av. José Padovani, onde há conjuntos realizados a partir dos anos 1980.

Vinhedo também apresenta as Habitações de Interesse Social localizadas em duas áreas, uma ao longo da rodovia Anhanguera, com conjuntos realizados a partir dos anos 1980, e outra, mais próxima do centro da cidade, ao norte da área central, com seis conjuntos mais inseridos no tecido urbano, sendo que um deles é do primeiro período, outros dois dos anos 1980, um dos anos 1990 e outros dois do último período. Assim como ocorre em outros municípios, quando os primeiros conjuntos foram realizados, localizavamse em áreas distantes do tecido urbano consolidado, embora os três conjuntos do último período tenham sido implantados em área de urbanização consolidada. Entretanto, pode-se notar que tanto a maioria dos conjuntos quanto aqueles de maiores dimensões realizados a partir dos anos 1980 ocorrem na primeira área, próximos à rodovia Anhanguera e bastante distantes da área central (ver Mapa 18, p. 154).

Observou-se que em Paulínia ${ }^{109}$ e Vinhedo tornam-se bastante demarcadas as localizações das populações mais pobres, com a delimitação de áreas específicas para Habitações de Interesse Social. Esses municípios também apresentam uma grande quantidade de condomínios e loteamentos fechados ${ }^{110}$. Pode-se perceber, portanto, a delimitação territorial de locais específicos para HIS, como parte do mesmo processo de segregação que suscita a implantação dos empreendimentos fechados, voltados para a classe de renda oposta.

\footnotetext{
${ }^{109}$ Cabe notar que a maioria dos condomínios e loteamentos fechados em Paulínia, voltados para a classe média alta e alta, localiza-se em setores da cidade distintos daqueles voltados para as HIS, principalmente ao longo da Rodovia Zeferino Vaz e da Av. José Paulino.

${ }^{110}$ Sobre os padrões de ocupação de cada vetor de expansão da RMC, ver Caiado e Pires (2006). Sobre os condomínios e loteamentos fechados aprovados na RMC, ver Freitas (2008).
} 
Mapa 17 - Habitações de Interesse Social produzidas em Paulínia (1964-2014) - limite municipal

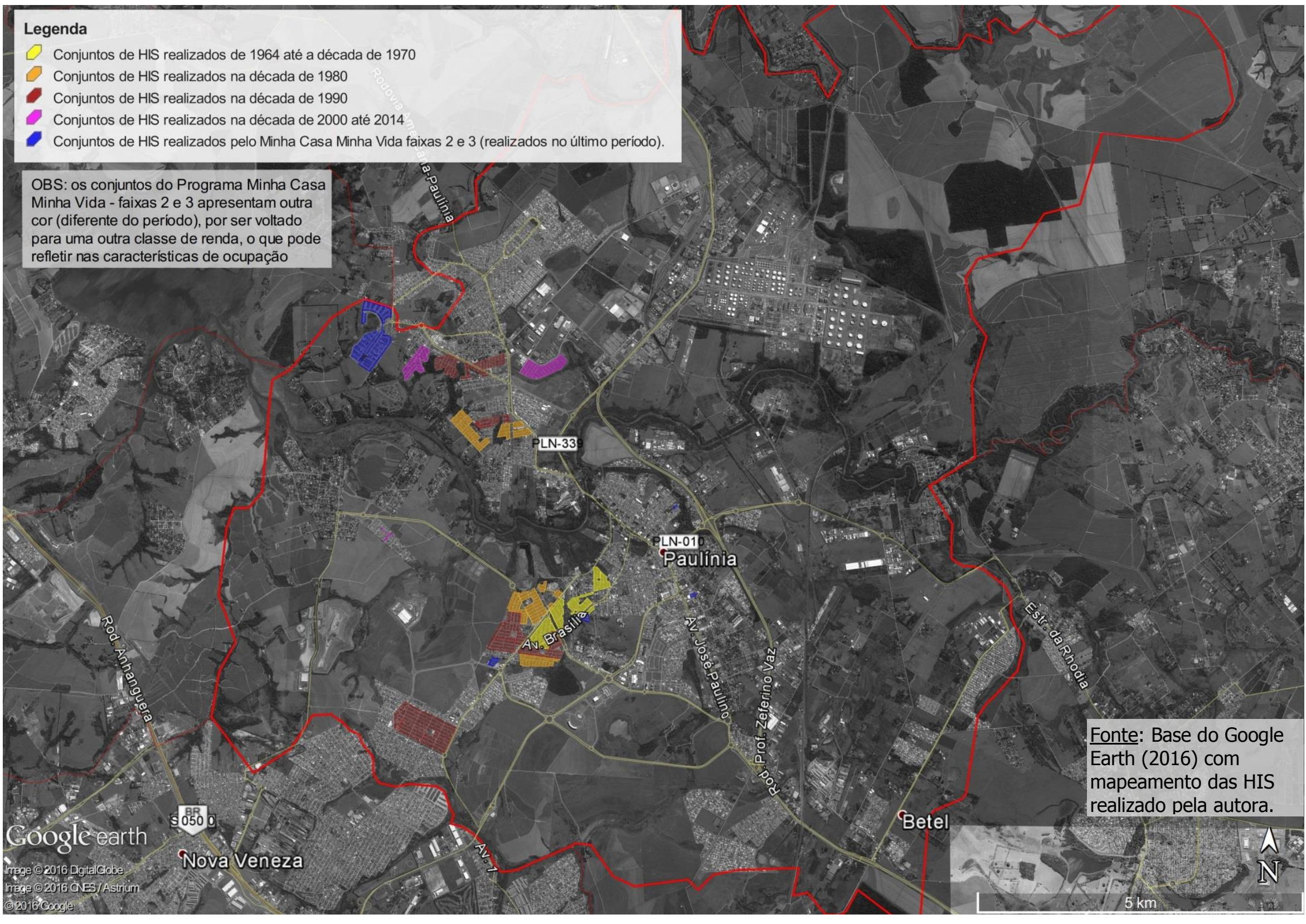


Mapa 18 - Habitações de Interesse Social produzidas em Vinhedo (1964-2014) - limite municipal

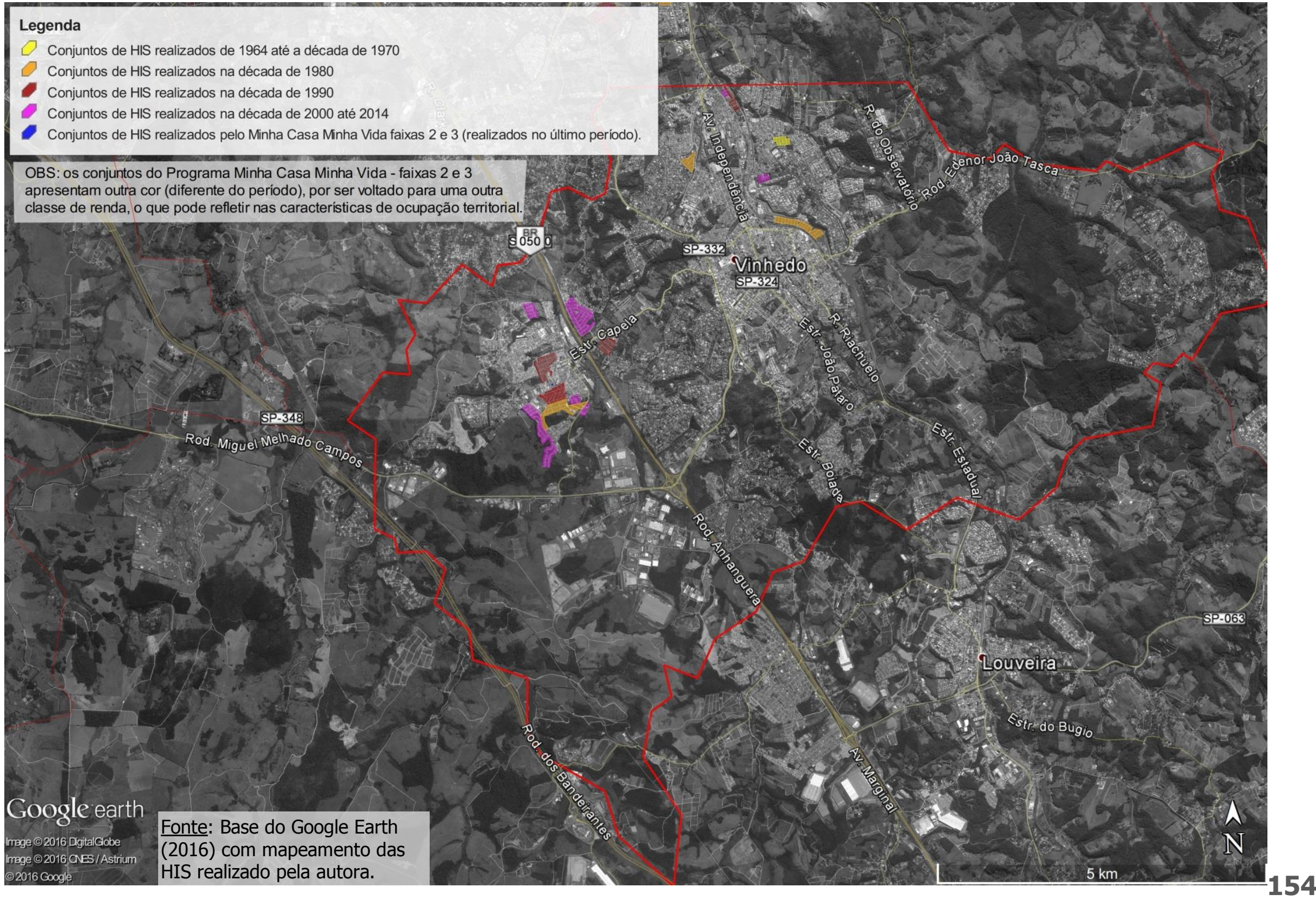




\section{Grupo IV}

Estão relacionados nesse grupo os municípios em que os conjuntos de Habitação de Interesse Social localizam-se de forma mais dispersa pelo tecido urbano, embora ocupem prioritariamente um determinado setor da cidade: Artur Nogueira, Cosmópolis, Indaiatuba e Jaguariúna.

Em Artur Nogueira há conjuntos de Habitação de Interesse Social realizados a partir dos anos 1980 e todos se localizam no setor norte - nordeste do município (Mapa 19, p. 156). Em Cosmópolis, podem-se notar conjuntos realizados entre 1970 e 2012 e, embora estejam mais dispersos no território do que em Artur Nogueira, eles ocupam o vetor noroeste - nordeste da cidade (Mapa 20, p. 157). Em Jaguariúna, há conjuntos de HIS realizados entre 1975 e 2014 e, assim como em Cosmópolis, estão mais dispersos pelo território, embora ocupem predominantemente o vetor noroeste - norte da cidade (Mapa 22, p. 159). Em Indaiatuba, podem-se observar conjuntos realizados entre 1974 e 2014, cuja ocupação ocorre principalmente no vetor sudoeste da cidade (Mapa 21, p. 158). Tanto em Jaguariúna quanto em Indaiatuba, há alguns poucos conjuntos que não foram implantados no vetor mencionado, mas em locais longínquos, bastante distantes das áreas de urbanização consolidada.

Nos quatro municípios, pode-se observar que os conjuntos de Habitação de Interesse Social estão um pouco mais inseridos no tecido urbano do que nos grupos I, II e III (p. 138 a 152). Entretanto, eles situam-se majoritariamente em um determinado vetor da cidade, e os mais próximos das áreas centrais são os realizados nos anos 1970 e 1980, ou seja, quando foram implantados, situavam-se também de forma distante; apenas apresentam hoje uma boa localização devido ao crescimento da mancha urbana. Há exceções, como em Jaguariúna e em Indaiatuba, onde se podem observar conjuntos realizados no último período e bem localizados, embora sejam poucos casos.

É importante observar que, entre os quatro municípios do grupo IV, que apresentam os conjuntos de Habitações de Interesse Social mais inseridos no tecido urbano, três são municípios pequenos - apenas Indaiatuba é um município grande (conforme classificação do Mapa 2, p. 33) e nenhum deles situa-se ao longo do principal eixo de locomoção da Região Metropolitana de Campinas, a rodovia Anhanguera. Portanto, é possível notar que, quando as HIS apresentam uma localização melhor, por outro lado, o município é periferia da Região Metropolitana. 
Mapa 19 - Habitações de Interesse Social produzidas em Artur Nogueira (1964-2014) - limite municipal

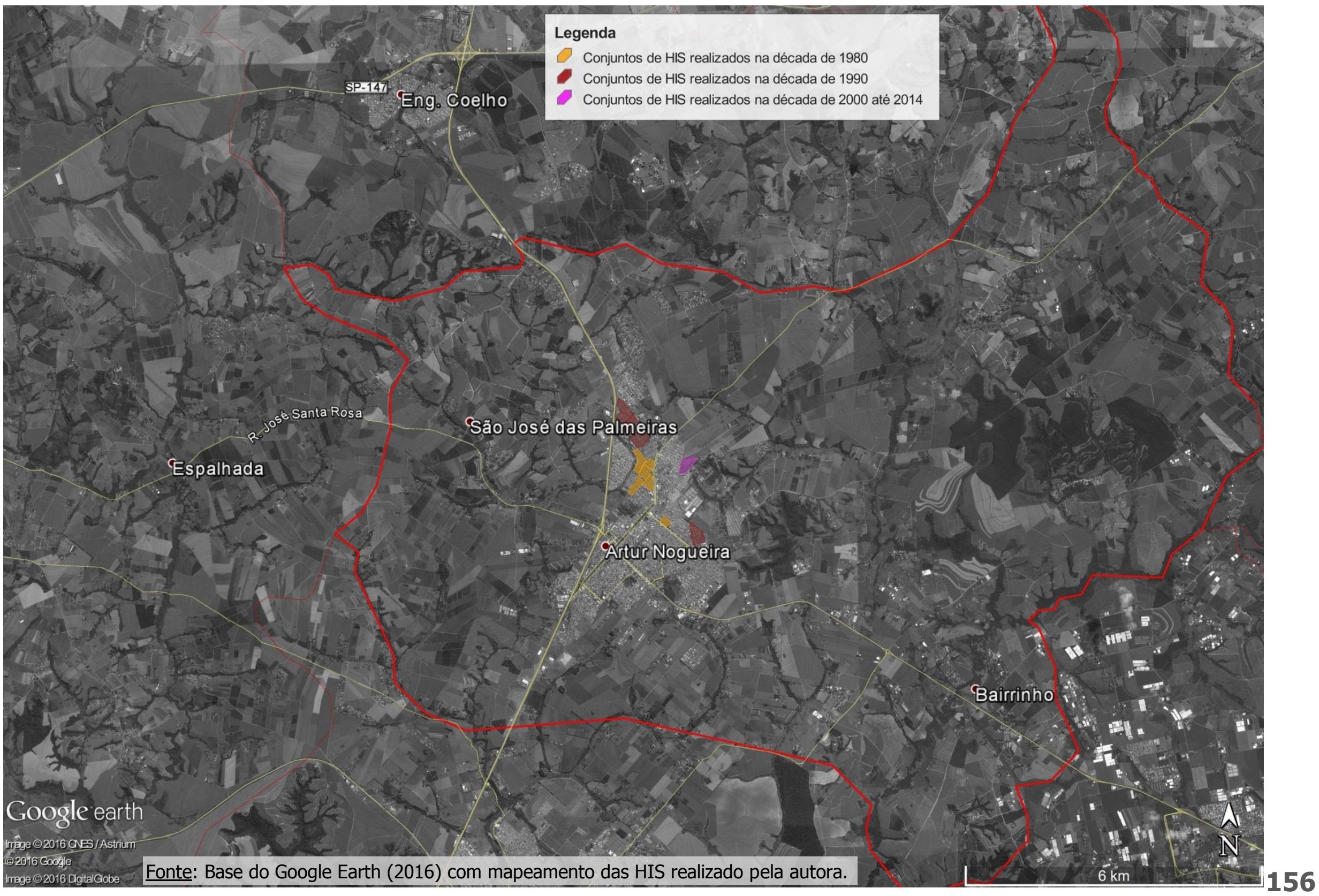


Mapa 20 - Habitações de Interesse Social produzidas em Cosmópolis (1964-2014) - limite municipal

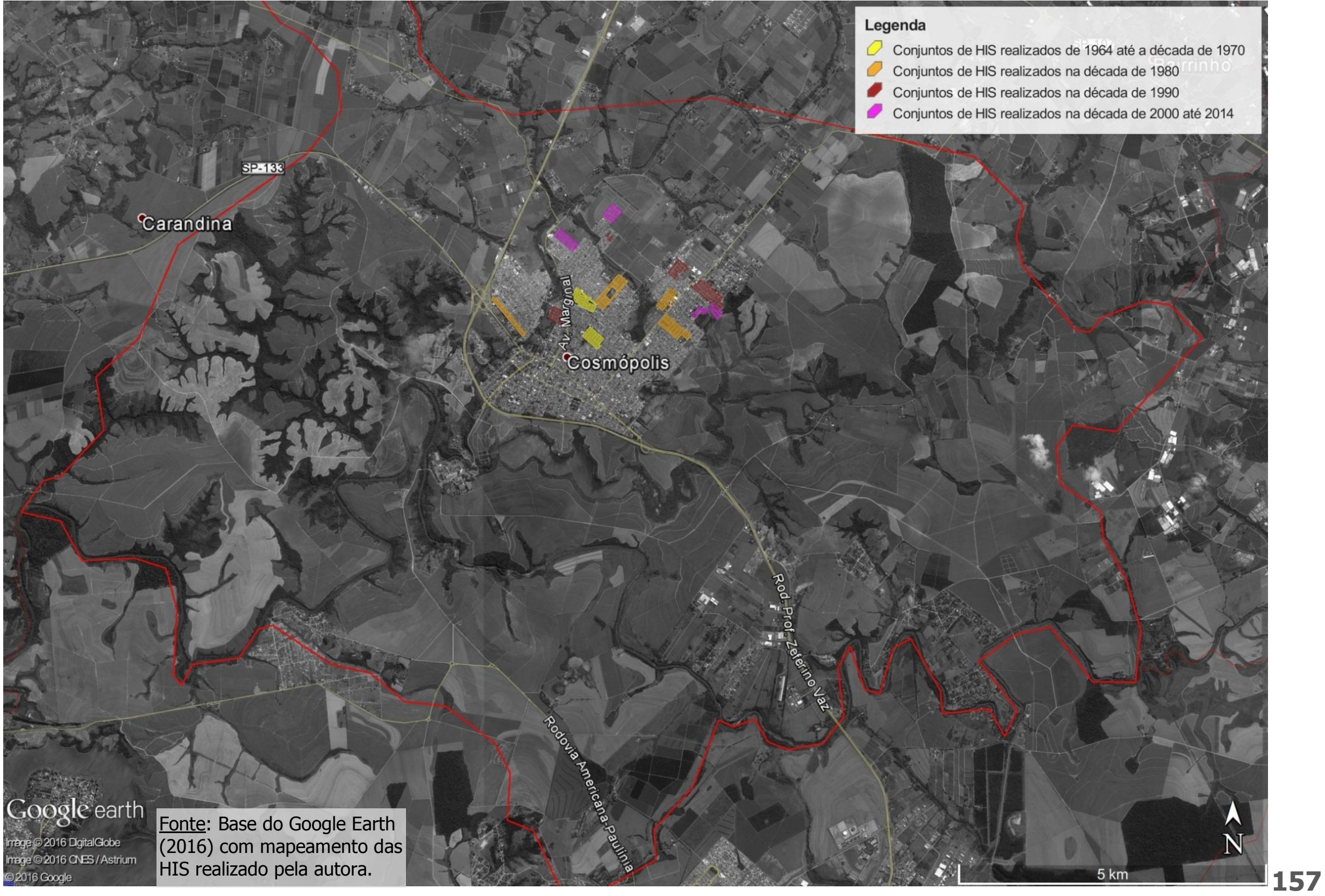




\section{Mapa 21 - Habitações de Interesse Social produzidas em Indaiatuba (1964-2014) - limite municipal}

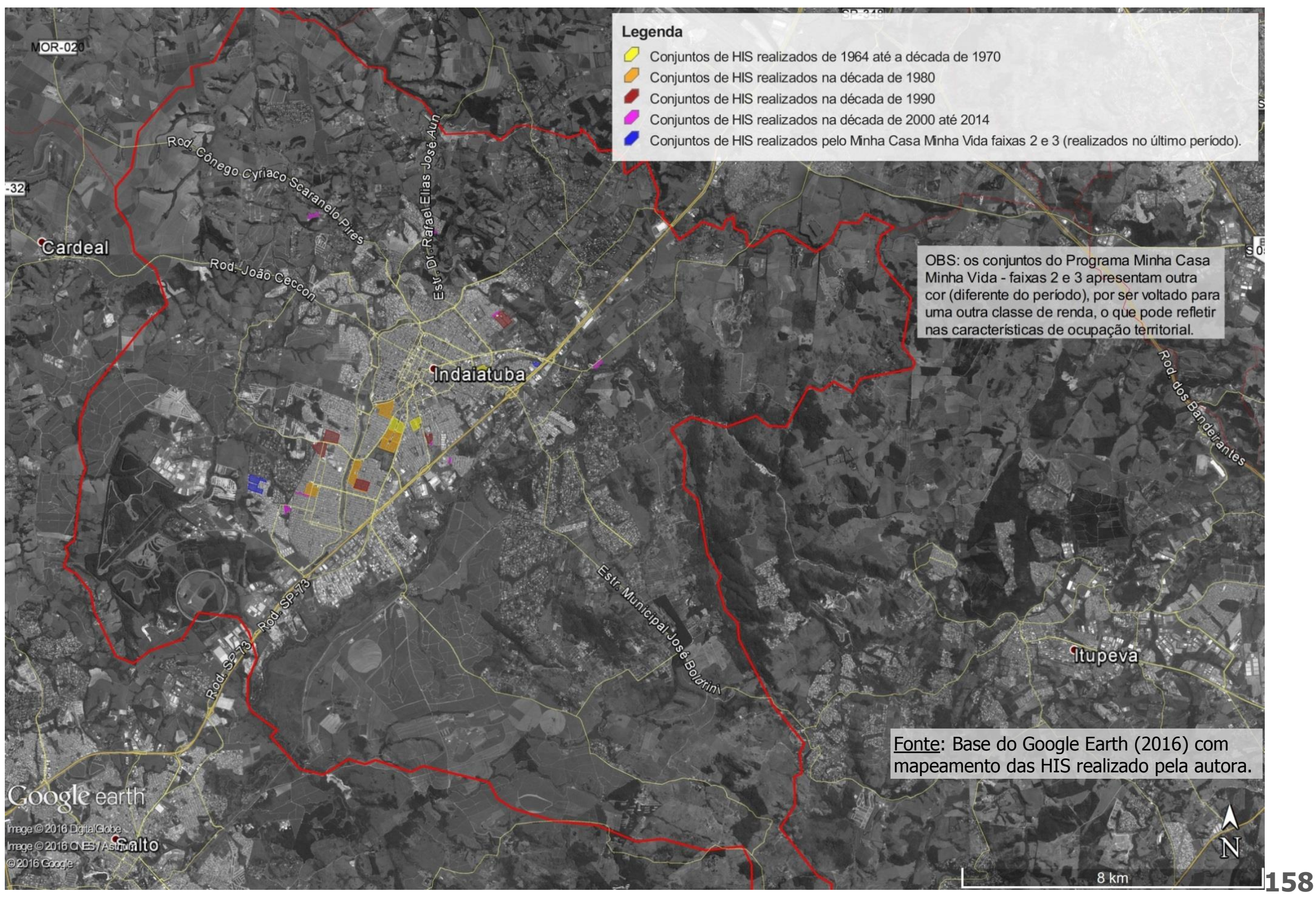


Mapa 22 - Habitações de Interesse Social produzidas em Jaguariúna (1964-2014) - limite municipal

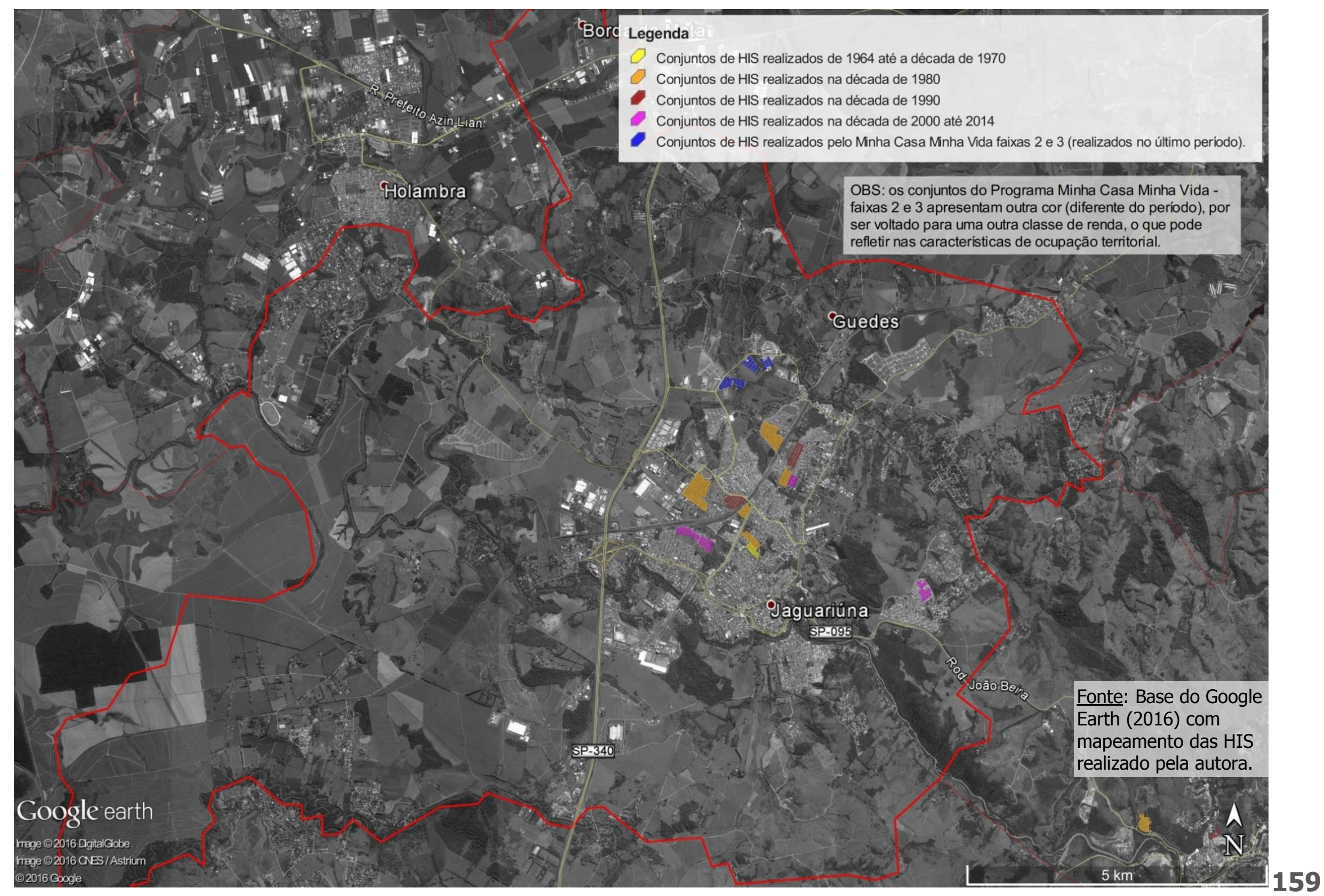




\section{Grupo V}

No último grupo, foram listados cinco municípios pequenos - Engenheiro Coelho, Holambra, Monte Mor, Morungaba e Santo Antônio de Posse, que apresentam poucos conjuntos de Habitação de Interesse Social, cujas localizações podem ser observadas de forma concentrada em um determinado vetor das cidades.

Em Engenheiro Coelho ocorre de modo um tanto diferente: há dois conjuntos de HIS que não estão localizados próximos um do outro, mas ambos se situam a leste do lago que divide a cidade, conforme Mapa 23 (p. 162). A partir da visita técnica ao município, pôde-se perceber que a oeste do lago situa-se o centro do município, assim como lotes maiores e, consequentemente, casas voltadas à classe de maior renda, enquanto que a leste do lago localizam-se bairros mais populares, com lotes menores ${ }^{111}$.

Em Holambra, foram realizados dois conjuntos de HIS, que se situam na região oeste do município, bastante próximos da área central. Eles estão em áreas adjacentes e nos dois casos foram doados lotes grandes (de 200 a $500 \mathrm{~m}^{2}$ ) para os munícipes construírem (Mapa 24, p. 163). Cabe lembrar que, nesse município, a área mais valorizada é a área rural, devido à produção de flores, portanto, a lógica da localização, embora seja próxima à área central do município, é distante das áreas onde o solo apresenta maior valor.

Em Monte Mor, há três conjuntos de HIS, realizados entre 1970 e 2000, todos em áreas próximas, na região norte do município. Cabe lembrar que o município apresenta um território bastante espraiado, com áreas urbanizadas permeadas por vazios, entretanto as HIS não estão distantes da área central, conforme se pode observar no Mapa 25 e no Mapa 26 (p. 164 e 165).

Em Morungaba, foram realizados quatro conjuntos de HIS, um em cada período analisado, sendo que todos se situam próximos, no vetor noroeste do município (Mapa 27 e Mapa 28, p. 166 e 167).

Em Santo Antônio de Posse, podem-se notar sete conjuntos de HIS implantados, sendo que seis deles localizam-se em áreas bastante próximas, na região leste do município; apenas um pequeno conjunto localiza-se na região norte (Mapa 29 e Mapa 30, p. 168 e 169).

\footnotetext{
111 Em entrevista com técnicos municipais, o padrão de ocupação observado visualmente foi confirmado, inclusive, foi relatado que a leste do lago, onde se observam os dois conjuntos de HIS, há diversos casos de coabitação. Há moradores que constroem como anexo de suas habitações diversos quartos e um banheiro para alugar para trabalhadores temporários, principalmente os da colheita de laranja. Esses quartos, realizados de forma irregular, são identificáveis visualmente, pois, em muitos casos, ocupam as áreas de recuo e, às vezes, as calçadas dos lotes, caracterizando uma precariedade habitacional.
} 
Percebe-se que, apesar das especificidades territoriais, todos os municípios apresentam uma pequena área urbanizada. Foram realizados neles entre dois e sete empreendimentos habitacionais, que se localizam em um determinado vetor das cidades, em áreas bastante próximas das áreas centrais. Portanto, pode-se notar que os municípios cujas HIS estão mais inseridas no tecido ou mais próximas das áreas centrais, como se observou neste grupo e no grupo IV (p. 153), são pequenos ou as HIS apresentam uma localização periférica em relação à região metropolitana. 
Mapa 23 - Habitações de Interesse Social produzidas em Engenheiro Coelho (1964-2014) - limite municipal

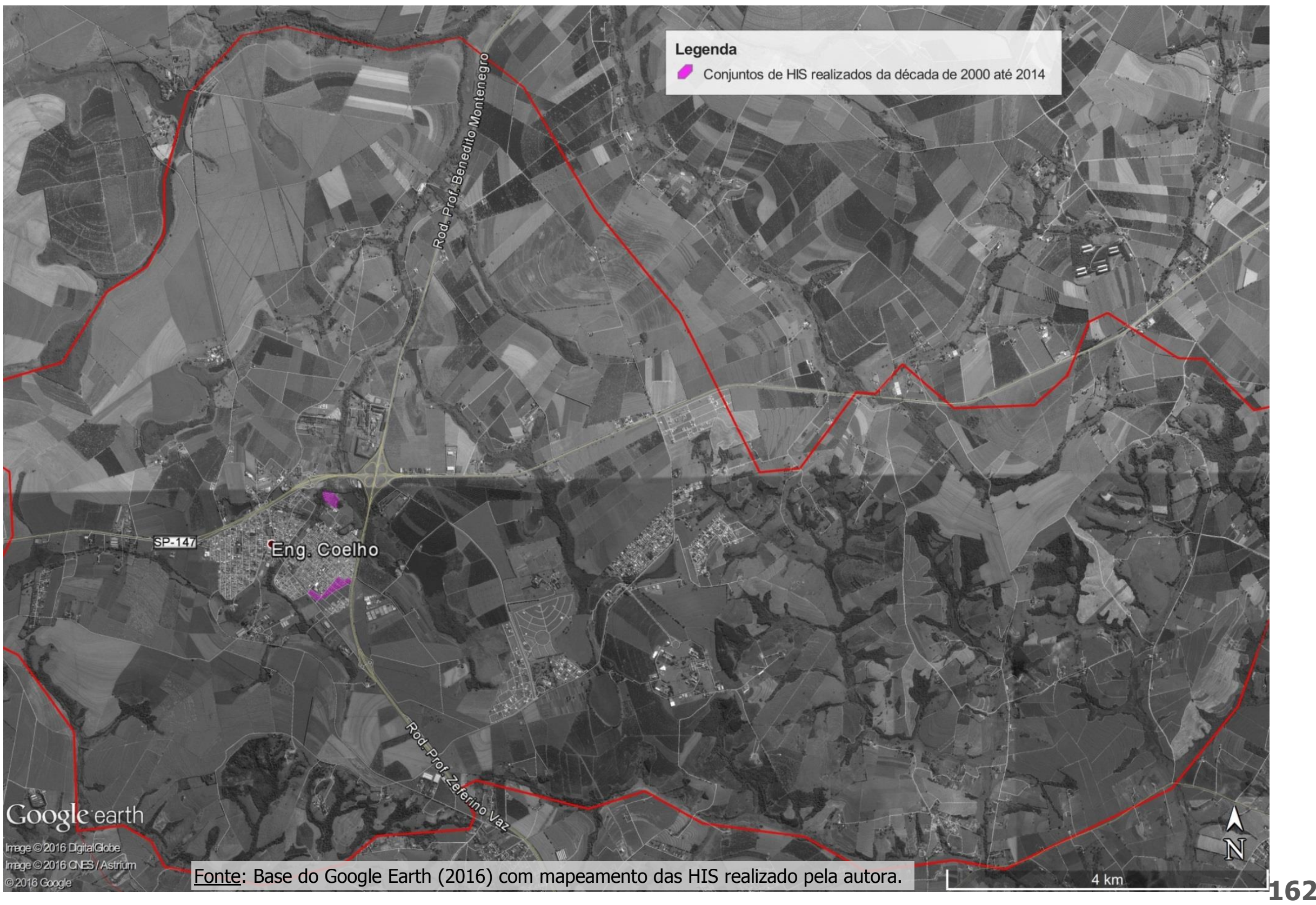




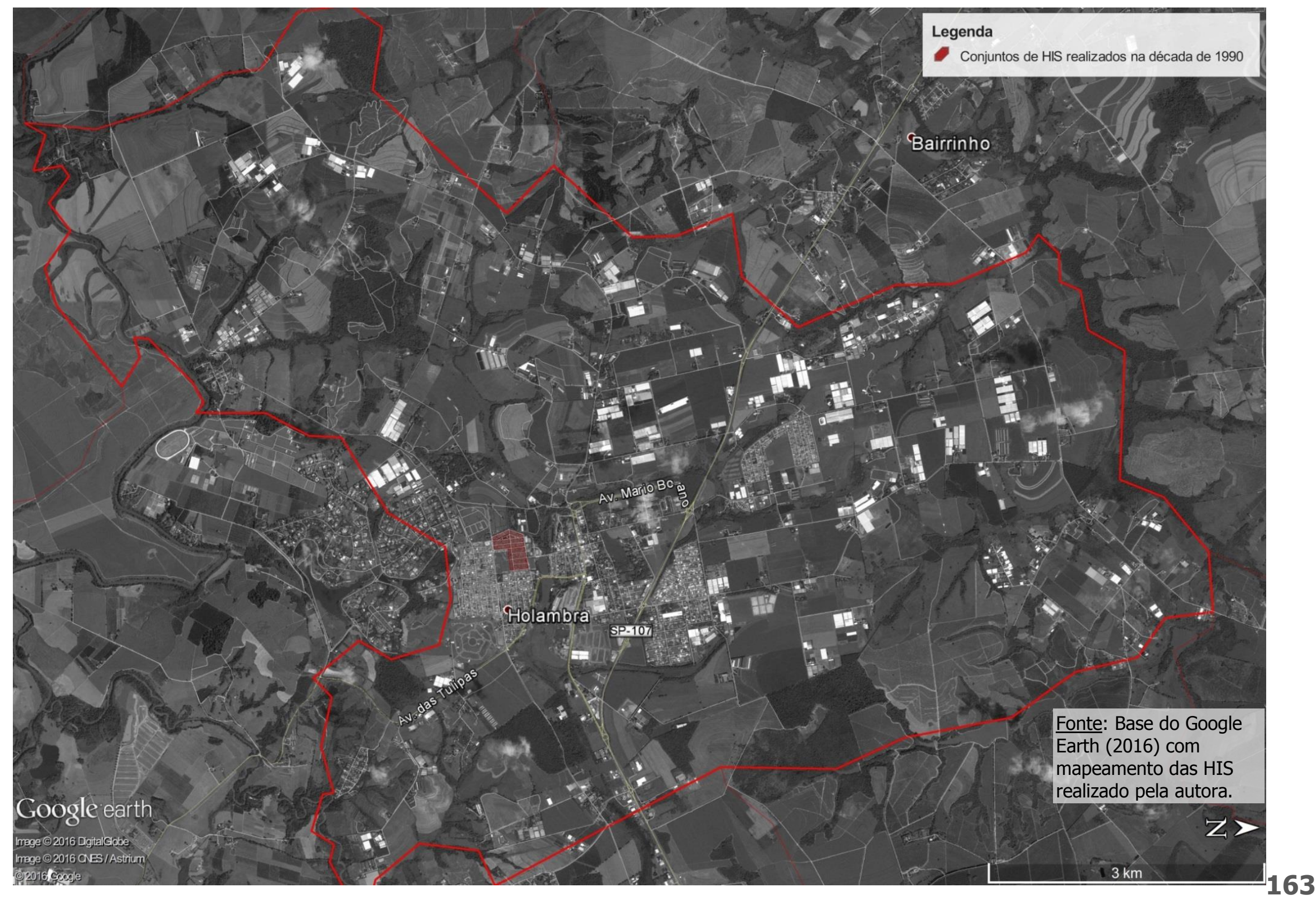


Mapa 25 - Habitações de Interesse Social produzidas em Monte Mor (1964-2014) - limite municipal

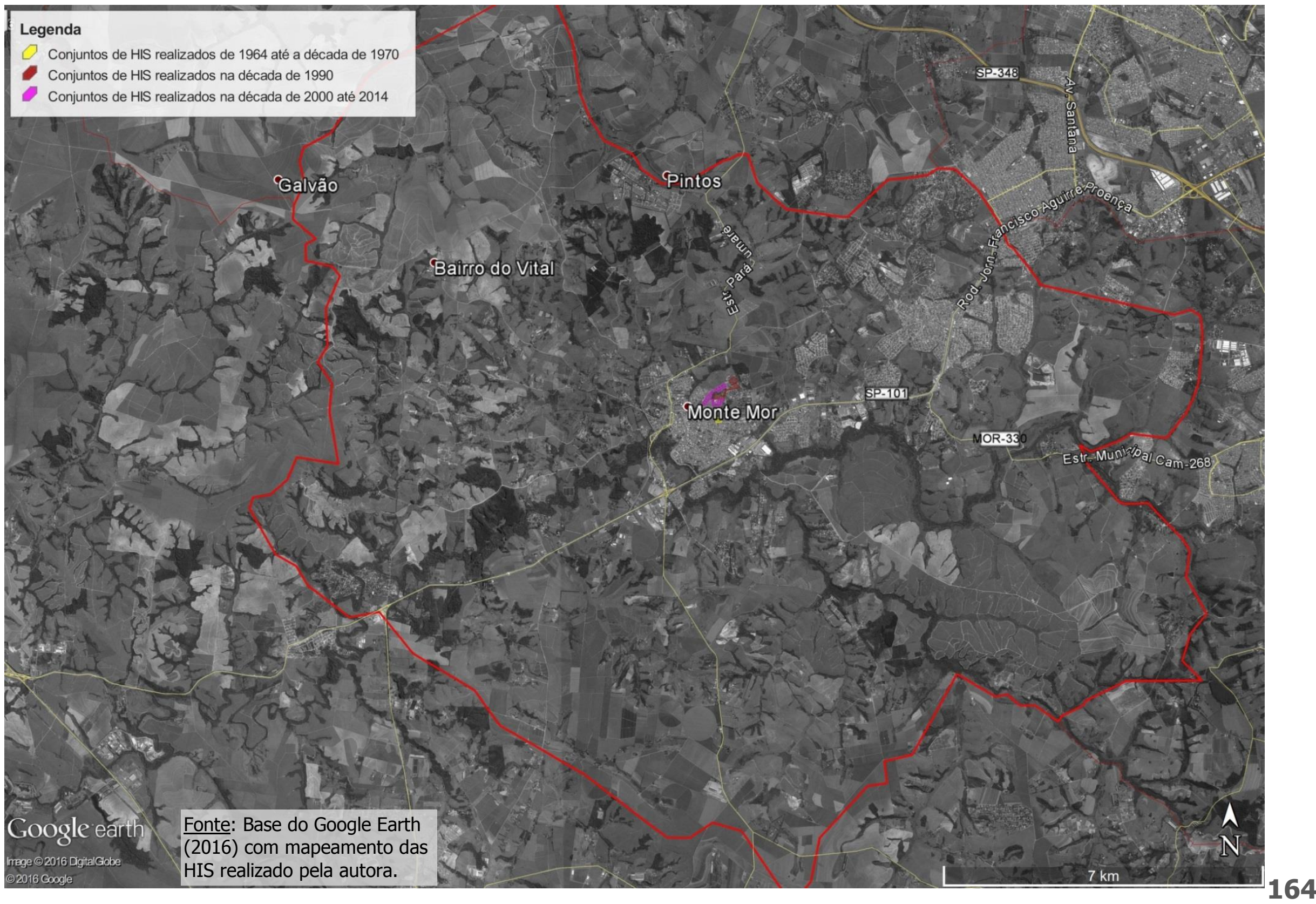


Mapa 26 - Habitações de Interesse Social produzidas em Monte Mor (1964-2014) - área urbanizada

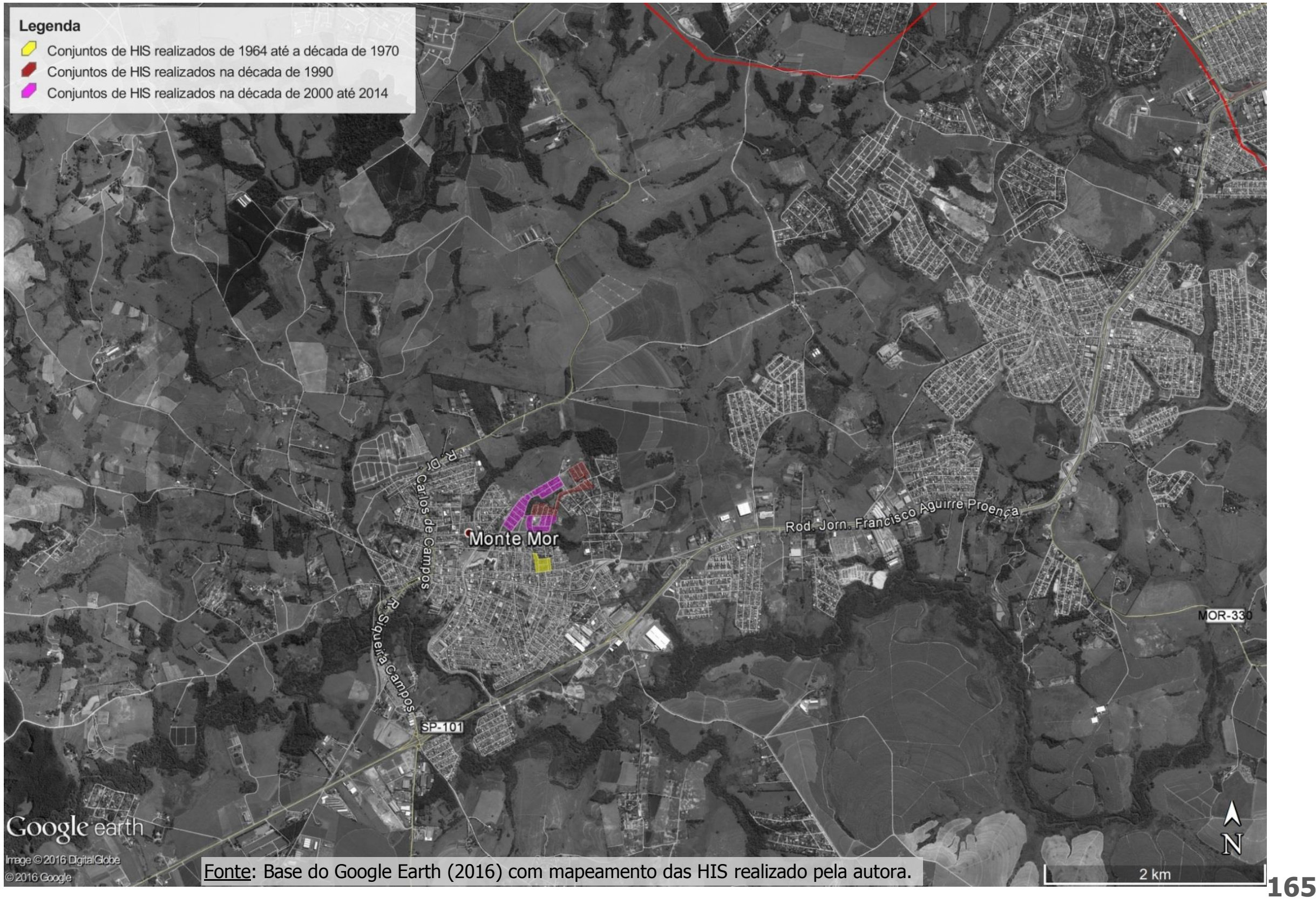


Mapa 27 - Habitações de Interesse Social produzidas em Morungaba (1964-2014) - limite municipal

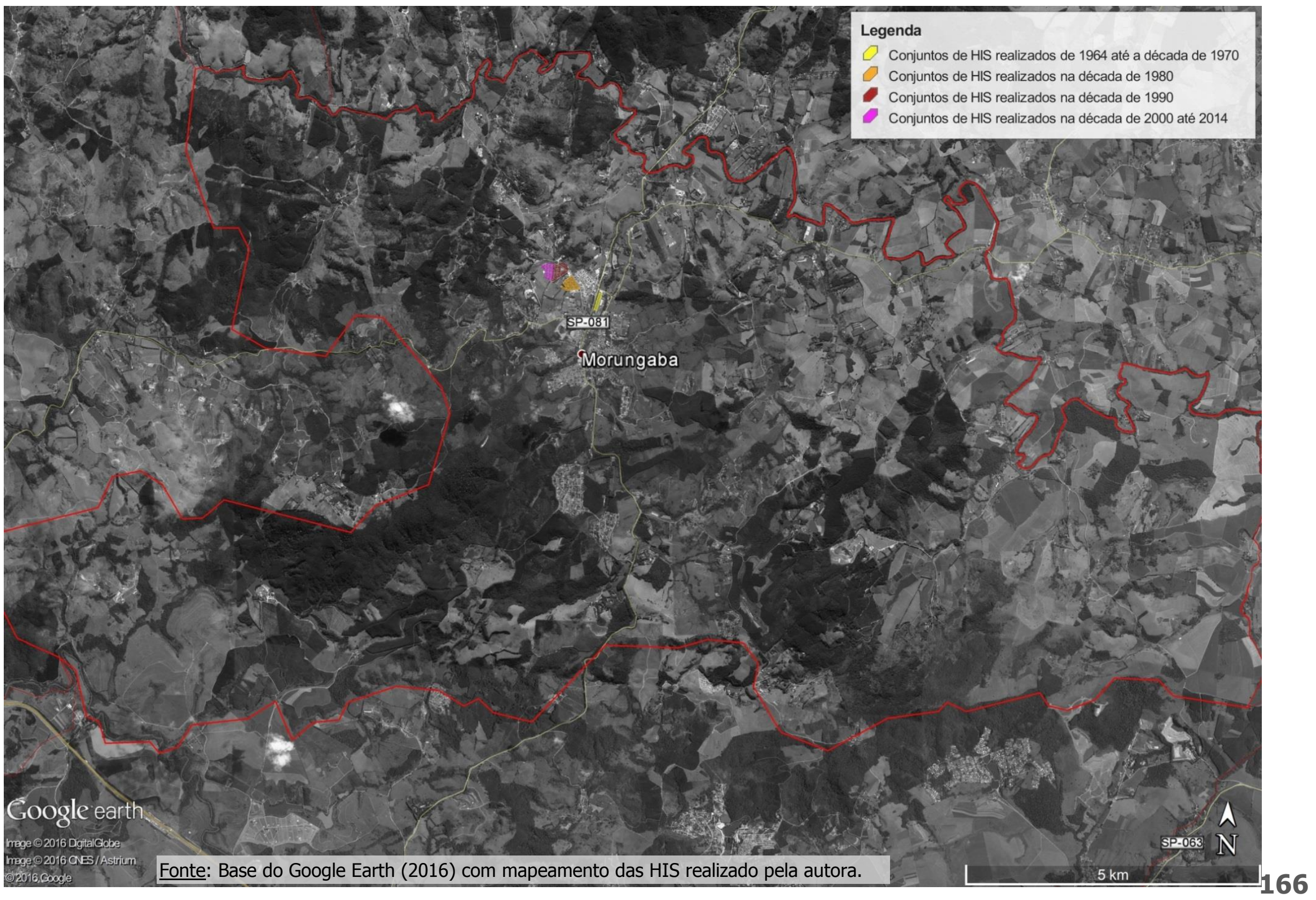


Mapa 28 - Habitações de Interesse Social produzidas em Morungaba (1964-2014) - área urbanizada

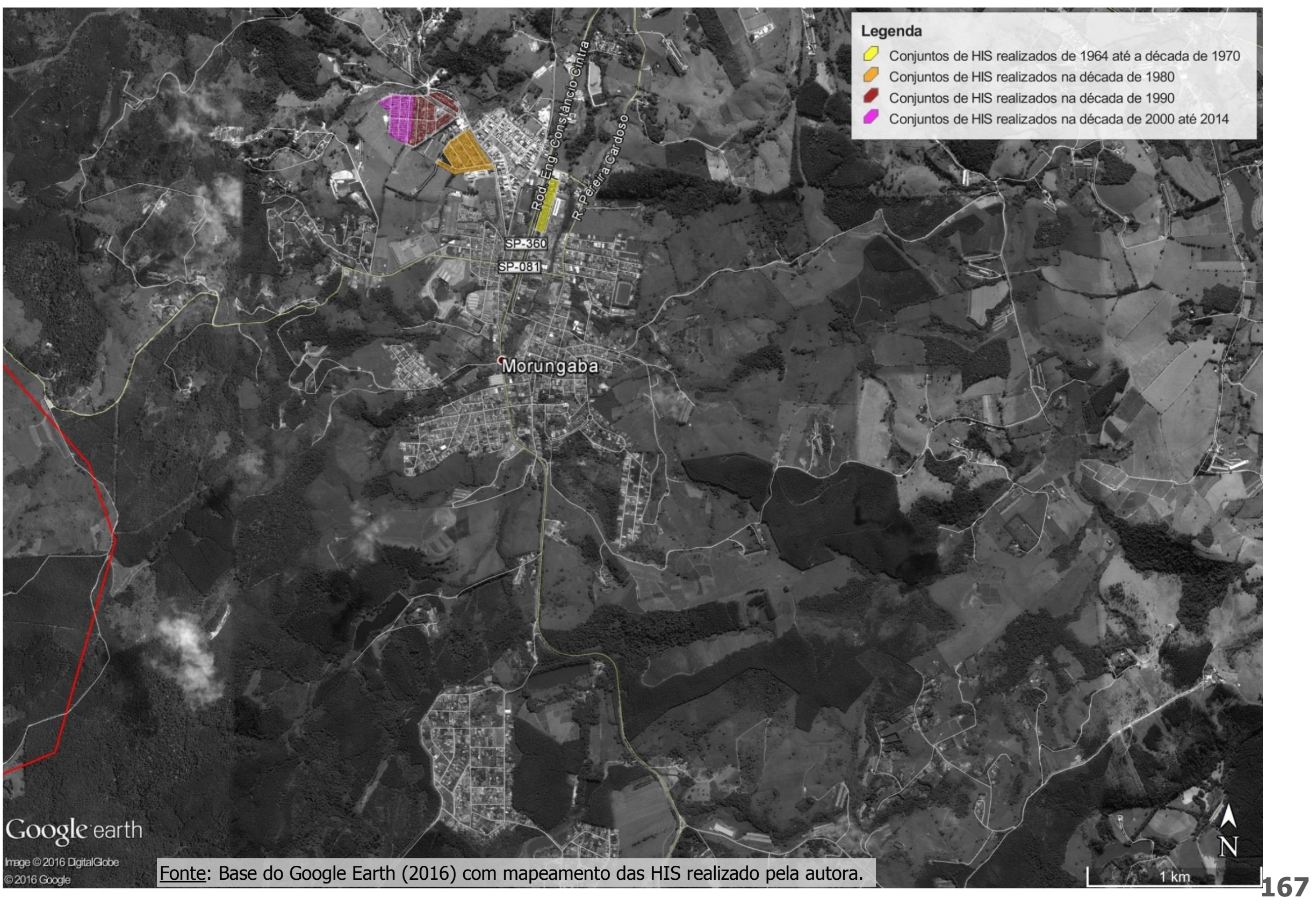


Mapa 29 - Habitações de Interesse Social produzidas em Santo Antônio de Posse (1964-2014) - limite municipal

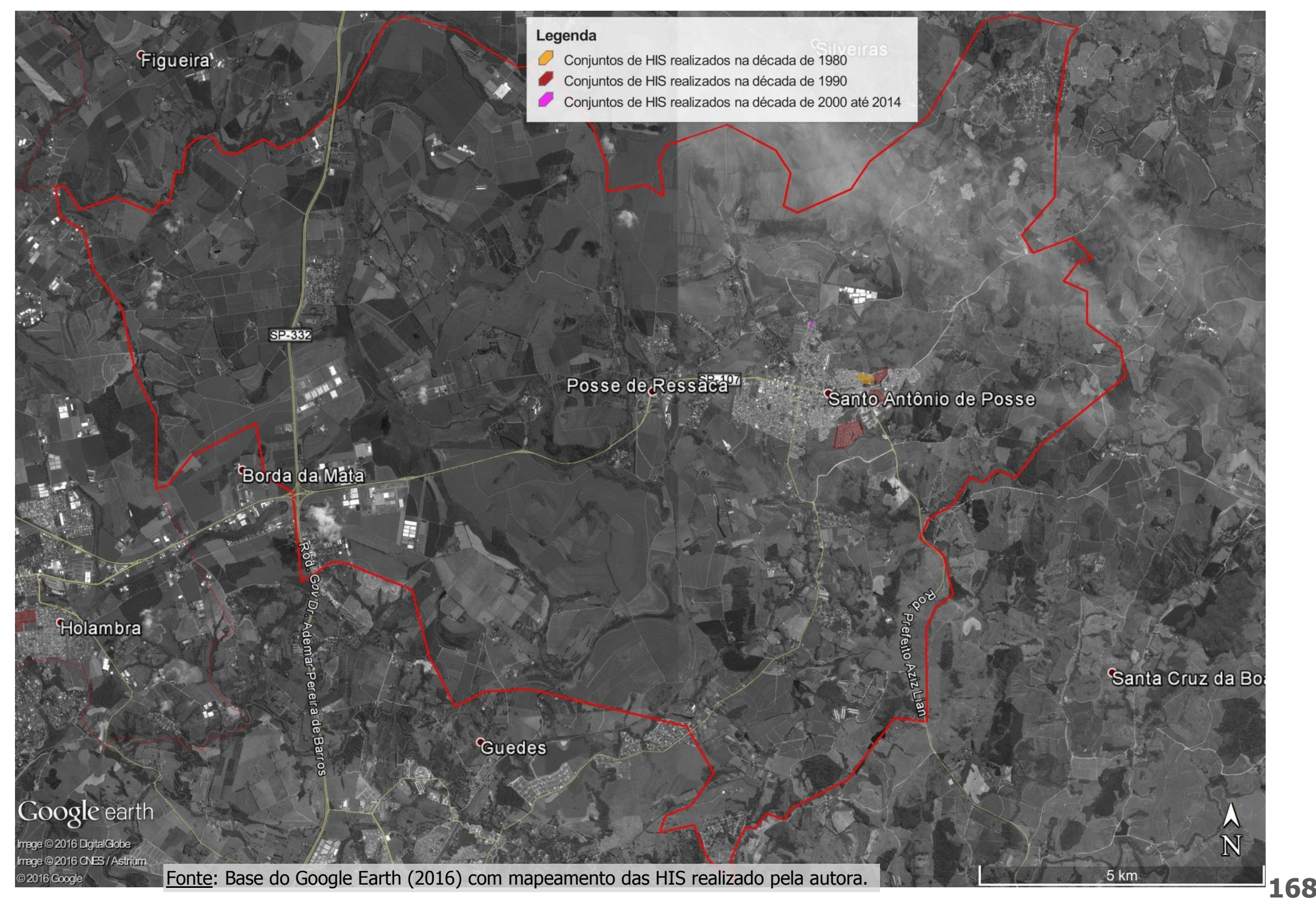


Mapa 30 - Habitações de Interesse Social produzidas em Santo Antônio de Posse (1964-2014) - área urbanizada

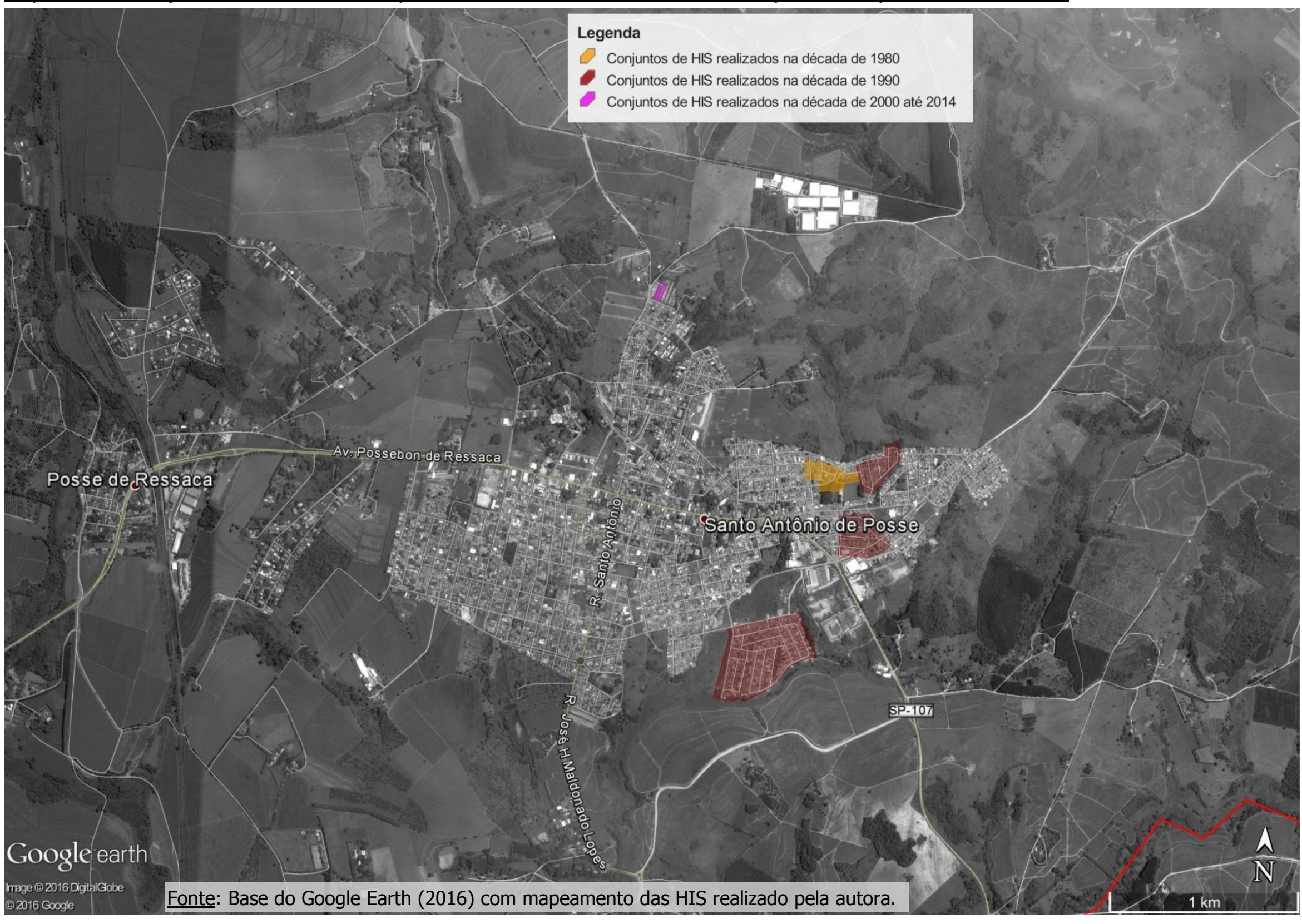


Considerações sobre as tipologias de ocupação das Habitações de Interesse Social nos municípios sob enfoque individual

A partir das análises das localizações das Habitações de Interesse Social nos municípios da Região Metropolitana de Campinas, foi possível identificar cinco grupos que caracterizam diferentes formas de ocupação.

As formas de ocupação definidas como grupos I e II caracterizaram-se por apresentar as HIS nas bordas das áreas urbanizadas, sendo que no primeiro grupo há áreas de concentração dessas HIS em determinados setores das cidades, enquanto no segundo as HIS estão em dispersas em várias áreas das cidades. O grupo III apresentou duas áreas específicas para as HIS nos tecidos urbanos, enquanto no grupo IV podem-se observar as HIS mais dispersas pelo tecido urbano, um pouco mais inseridas nas cidades, embora estejam localizadas em um determinado setor delas. No grupo $\mathrm{V}$, estão os municípios pequenos, onde a maioria das HIS também se localiza nas periferias dos tecidos urbanos, também concentradas em um determinado setor das cidades.

Pode-se então perceber que, tanto no grupo I (p. 138) quanto no grupo II (p. 146), a lógica de implantação dos conjuntos de Habitação de Interesse Social foi em áreas distantes dos serviços, equipamentos e infraestrutura, às margens das cidades. Esse padrão pode ser observado inclusive nos municípios pequenos do grupo V (p. 153), nos quais as distâncias até os centros urbanos são menores, mas a lógica de ocupação se apresentou exatamente a mesma. Como colocado na pesquisa (FERRAMENTAS [...], 2014), se o Programa Minha Casa Minha Vida faixa 1 pode ter atingido uma classe antes não atendida pelos programas habitacionais, não influenciou no seu 'lugar' histórico nas cidades, reproduzindo e reforçando o padrão periférico. Percebe-se, portanto, que as Habitações de Interesse Social nesses catorze municípios da RMC foram, independentemente dos agentes financeiros ou programas habitacionais envolvidos, implantadas nas áreas periféricas dos tecidos urbanos.

Foi possível notar que a ocupação dos conjuntos mais recentes na RMC, realizados a partir dos anos 1990, ocorre de modo geral em periferias consolidadas, pois a maioria dos conjuntos ocupa áreas remanescentes de conjuntos produzidos nas décadas anteriores. No entanto, embora essas periferias apresentem alguma diversidade de comércio e serviços e alguns equipamentos públicos, consolidaram-se a partir de um padrão de urbanização precário e fragmentado.

No grupo classificado como III, há dois municípios - Vinhedo e Paulínia - que apresentaram em seus tecidos urbanos duas áreas específicas para as Habitações de 
Interesse Social (ver Mapa 17 e Mapa 18, p. 153 e 154). Cabe notar que essas áreas não são muito próximas às áreas centrais, ou seja, embora não sejam as bordas dos tecidos urbanos, são áreas específicas destinadas a essa população, em grande parte, com características semelhantes as das periferias supracitadas nos grupos I, II e V. Considerando as quatro áreas voltadas às HIS nesses dois municípios, apenas uma delas, a área mais próxima da área central no caso de Vinhedo, não apresentou as características de periferia.

Pode-se então observar que, entre os vinte municípios da Região Metropolitana de Campinas (RMC), dezesseis deles apresentam as Habitações de Interesse Social em áreas de periferia ou com essas características. Com uma forma de ocupação um pouco diferente, há os quatro municípios classificados como grupo IV (p. 153), em cujos tecidos urbanos as HIS estão um pouco mais inseridas, embora elas ocupem sempre setores específicos das cidades. Cabe ainda observar que nenhum desses quatro municípios localiza-se ao longo do eixo da rodovia Anhanguera, via com maior fluxo e movimento pendular da RMC.

Cabe notar, ainda, que os municípios de Valinhos, Campinas, Hortolândia, Sumaré, Nova Odessa e Americana, que têm como eixo principal a rodovia Anhanguera ${ }^{112}$, foram classificados como grupos I e II, pois apresentam os conjuntos de HIS de forma periférica, nas bordas do tecido urbano. Pode-se, portanto, observar que, de modo geral, quando o município tem uma localização privilegiada na região metropolitana, as HIS estão periféricas em seu tecido urbano, e quando elas estão mais bem localizadas nas cidades, esses municípios já se apresentam como periferia da região.

\footnotetext{
${ }^{112}$ No eixo da rodovia Anhanguera, encontra-se também o município de Vinhedo, classificado como grupo III por apresentar duas áreas específicas para as HIS. Cabe notar que uma dessas duas áreas voltadas para HIS em Vinhedo localiza-se próxima à Anhanguera e apresenta características semelhantes às dos municípios dos grunos I e II. Com uma ocupação diferente, nota-se a minoria dos conjuntos de Vinhedo localizada mais rrúxiima da área central do município.
} 


\subsubsection{A escala metropolitana: implantação das HIS no contexto da Região Metropolitana de Campinas}

As Habitações de Interesse Social (HIS) realizadas entre 1964 e 2014 nos vinte municípios da Região Metropolitana de Campinas foram mapeadas conforme metodologia descrita na primeira parte deste capítulo (p. 126).

As localizações das HIS na RMC podem ser observadas no Mapa 33 (p. 181), estando seus perímetros demarcados por meio de cinco cores, de acordo com o período ou programa habitacional: amarela - HIS realizadas entre 1964 e 1979; laranja - HIS realizadas entre 1980 e 1989; vermelha - HIS realizadas entre 1990 e 1999; magenta - HIS realizadas entre 2000 e 2014, exceto MCMV; e azul - HIS realizadas no último período pelo PMCMV.

No Mapa 33, identifica-se uma urbanização mais contínua, com diversos municípios conurbados ao longo do eixo da rodovia Anhanguera. O início desse processo de expansão urbana pôde ser observado nos anos 1970, quando a população apresentou um grande fluxo migratório, sendo que o maior crescimento ocorre em Sumaré, seguido de Nova Odessa e de Santa Bárbara d'Oeste ${ }^{113}$.

Conforme os propósitos da presente tese, o objetivo é identificar o papel das políticas de habitação e da implantação de Habitação de Interesse social na estruturação do espaço urbano. Para essa análise, tomam-se por base os trabalhos de Caiado (1988) e Caiado e Pires (2006), com os quais se dialoga, inserindo a percepção territorial que o mapeamento aqui desenvolvido permite.

A expansão urbana dos anos 1970 cacacterizou-se pela "horizontalização e periferização dos espaços urbanizados", com diversos vazios urbanos constituindo-se como reserva de valor. Conforme coloca Caiado (1998, p. 467), nota-se esse padrão de urbanização no vetor sudoeste da cidade de Campinas, seguindo na direção dos municípios de Sumaré, Hortolândia, Monte Mor e Indaiatuba.

Na década de 1980, o município de Campinas destaca-se na perda de população para os municípios do entorno, processo que pôde ser observado com menor intensidade na década anterior. A despeito do arrefecimento no crescimento populacional e saldo migratório nos anos 1980, em comparação com o período anterior, as taxas apresentadas pela região

\footnotetext{
113 "Na verdade o Município de Sumaré, principalmente no que diz respeito ao então distrito de Hortolândia, emancipado em 1991, apresenta características de periferia, abrigando a população de mais baixa renda, que na sua grande maioria trabalha em Campinas. Nova Odessa e Santa Bárbara d'Oeste por sua vez assumem também o papel de periferia de Americana, considerado o segundo centro da Região, apresentando como Sumaré, altas taxas de crescimento do saldo migratório" (CAIADO, 1998, p. 466).

Sobre os fluxos populacionais na Região Metropolitana de Campinas, ver Baeninger (1999 e 2001).
} 
podem ser consideradas altas em relação ao território nacional. Sumaré e Monte Mor destacaram-se na década de 1980 com as maiores taxas de crescimento (CAIADO, 1998, p. 466-468).

A expansão urbana do território ocorreu principalmente ao longo da rodovia Anhanguera, devido à instalação industrial que orientou o sistema de interiorização do desenvolvimento, o qual privilegiou os eixos rodoviários regionais (CAIADO, 1998, p. 462472). A região de Campinas destacou-se como parque industrial desde o início de sua conformação como área metropolitana.

Nos anos 1990, a tendência de crescimento da população marca o processo de redistribuição no interior da RMC, apresentando o território de expansão metropolitana. Municípios mais distantes, como Artur Nogueira, Santo Antônio de Posse, Pedreira, Indaiatuba e Vinhedo, "não envolvidos diretamente no processo de periferização", desencadeado na década de 1970, são atingidos (CAIADO; PIRES, 2006, p. 279-280). Ainda para esses autores, "O crescimento populacional destes municípios e a elevação dos seus saldos migratórios na última década demonstram a intensificação das trocas intrametropolitanas e a configuração de novos espaços da migração no interior da RMC" (p. 279).

As áreas de expansão urbana acrescidas nos anos 1990, principalmente em Indaiatuba, Itatiba, Paulínia, Vinhedo, Valinhos e Jaguariúna, "correspondem ao maior volume de área urbanizada do período" (CAIADO; PIRES, 2006, p. 279), enquanto grande parte das novas áreas urbanas dos anos 1990 dos municípios de Hortolândia, Sumaré, Nova Odessa, Santa Bárbara d'Oeste, Americana, Cosmópolis e Monte Mor ocupam vazios existentes, resultantes das ocupações anteriores.

A expansão da Região Metropolitana de Campinas ${ }^{114}$ foi estudada por Caiado e Pires $(2006)^{115}$ a partir de sete vetores de crescimento metropolitano (Mapa 31, p. 174), cujas características serão aqui apresentadas. Esses vetores, definidos a partir dos principais eixos rodoviários, são adotados para a discussão da localização das HIS apresentadas no Mapa 33 (p. 181).

O desenvolvimento e as características do processo de expansão urbana metropolitana podem ser compreendidos, em parte, a partir das condições históricas de

\footnotetext{
${ }^{114}$ Como discutido no Capítulo I, a região de Campinas, embora apresente suas primeiras características de conformação metropolitana nos anos 1970, é instituída como região metropolitana apenas nos anos 2000.

${ }^{115}$ Caiado e Pires (2006) apresentam em um artigo a classificação dos sete vetores. Posteriormente, Pires (2007) discute em sua tese os mesmos sete vetores. Portanto, na discussão desses vetores de expansão urbana foram utilizados aqui os dois trabalhos.
} 
ocupação de Campinas e dos municípios do entorno, das rodovias e do que elas representaram enquanto local de instalação industrial (CAIADO; PIRES, 2006, p. 282-293).

O recorte territorial dos vetores foi baseado no agrupamento de zonas estabelecidas na pesquisa Origem e Destino, realizada na Região Metropolitana de Campinas em 2003 STM/Emplasa, 2003 (CAIADO; PIRES, 2006). As delimitações não foram definidas a partir dos limites municipais. A área delimitada externamente pela rodovia Anhanguera, pela rodovia Dom Pedro e pelo Anel Viário foi denominada como "centro metropolitano"; as demais zonas O/D foram alocadas nos diferentes vetores, conforme se apresenta no Mapa 31.

Mapa 31 - Vetores de Expansão da Região Metropolitana de Campinas

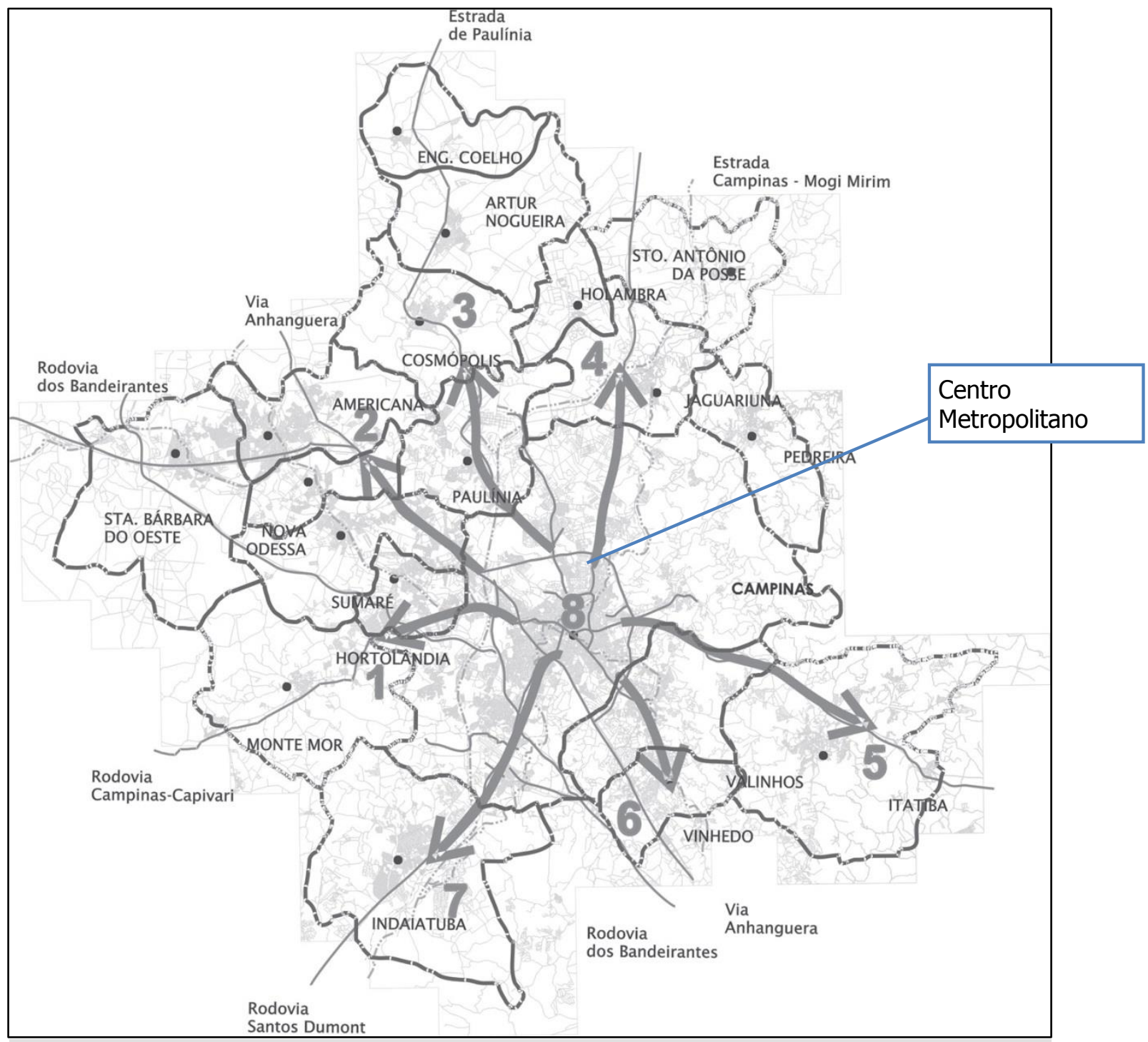

Fonte: Caiado e Pires (2006), p. 283.

No vetor denominado como 1 , no eixo oeste - noroeste do município de Campinas, seguindo em direção a Hortolândia e Monte Mor, consolida-se um padrão de urbanização caracterizado pela precariedade dos assentamentos urbanos. O tecido urbano é marcado por 
ocupações descontínuas, como local de indústrias e de moradia para a população de baixa renda, principalmente migrantes (PIRES, 2007, p. 29-31). Nesse vetor, pode-se observar no Mapa 33 (p. 181) uma quantidade considerável de Habitações de Interesse Social realizadas no município de Campinas, principalmente conjuntos de grande porte construídos no primeiro período (entre 1964 e 1979) e na década de 1980, enquanto os municípios de Hortolândia e de Monte Mor apresentaram conjuntos menores e mais recentes, como uma continuidade do processo de ocupação territorial.

O entorno da rodovia Anhanguera, principal eixo de localização industrial da RMC, configura o vetor 2 - que conecta parte de Campinas a Sumaré, Nova Odessa, Americana e Santa Bárbara d'Oeste. Também compõe esse vetor parte do município Hortolândia. O vetor 2 destaca-se como o mais populoso entre os sete vetores, e é onde se observa uma ocupação urbana praticamente contínua de Campinas até Americana, que, por sua vez, pode ser classificada como "centro sub-regional" (CAIADO e PIRES, 2006, p. 282). Nele é possível observar, também, a maior quantidade de aglomerados de Habitações de Interesse Social na RMC, conforme Mapa 33 (p. 181), sendo os maiores deles localizados no limite entre Campinas e Hortolândia e em Americana.

Americana, como centro sub-regional, influenciou diretamente na expansão de Santa Bárbara D’Oeste e Nova Odessa. É possível notar relações intensas entre esses municípios e, em menor proporção, com o centro metropolitano. Tanto em Sumaré, principalmente na área cortada pela rodovia Anhanguera, quanto em Hortolândia, observam-se diversos loteamentos irrregulares e precários, configurando-se como bairros-dormitório da população trabalhadora das indústrias da região ou da área central de Campinas (PIRES, 2007, p. 3233).

Cabe ainda notar que diversos conjuntos de Habitações de Interesse Social foram implantados a partir de políticas e programas públicos, entretanto, seguindo a mesma lógica dos conjuntos irregulares citados por Pires (2007), eles localizam-se, conforme Mapa 33 (p. 181), mais próximos da rodovia Anhanguera do que dos centros urbanos dos municípios. Essas localizações devem também ser compreendidas a partir da lógica de um tecido urbano disperso ${ }^{116}$, que, como coloca Reis (2006, p. 94), "é uma consequência do sistema rodoviário".

Tanto em Campinas quanto em Sumaré e Americana, podem ser observadas Habitações de Interesse Social nas cores amarela e laranja, assim como vermelha e

\footnotetext{
${ }^{116}$ Sobre o processo de dispersão urbana na Região Metropolitana de Campinas, ver Mitica (2007).
} 
magenta, o que indica que esses conjuntos foram realizados em todos os períodos analisados (ver Mapa 33). Conforme discutido, o início da formação da área metropolitana da região de Campinas, com ênfase nesse vetor, pode ser observado nos anos 1970, tendo o processo se intensificado nas décadas subsequentes, o que corroborou a implantação dessas HIS em todos esses períodos, sendo que muitas delas seguiram a lógica regional das rodovias ${ }^{117}$ para suas localizações.

Pode-se observar (Mapa 33, p. 181, e Tabela 8, p. 81) que a maior parte das unidades construídas pela COHAB-Campinas concentra-se no vetor 2 , destacando-se a implantação de grandes conjuntos habitacionais, como o Castelo Branco, com 1112 unidades (1967), o Padre Manuel da Nóbrega, com 2.024 unidades (a partir de 1976), o Vila Boa Vista, com 1.534 casas (1969), e o Padre Anchieta, com 3.564 unidades (1980). Esses grandes conjuntos habitacionais ultrapassaram a barreira física representada pela via Anhanguera, induzindo a expansão urbana nessa direção.

Nos vetores identificados como 3, 4 e 5 (ver Mapa 31, p. 174), articulados pelas rodovias Professor Zeferino Vaz/SP-332 (sentido Paulínia), Adhemar de Barros/SP-340 (sentido Jaguariúna) e Dom Pedro I/SP-066 (sentido Itatiba) ${ }^{118}$, as características da ocupação urbana são diferentes das observadas nos vetores 1 e 2 . Eles apresentam grande quantidade de habitações das classes de renda média e alta, com diversos centros de consumo de porte regional, além da Unicamp, Campus I da PUC-Campinas e outras instituições de pesquisa, como CPQD (Centro de Pesquisa e Desenvolvimento em Telecomunicações), CTI (Centro Tecnológico para Informática) e Ciatec (Companhia de Desenvolvimento do Polo de Alta Tecnologia de Campinas). Principalmente a partir dos anos 1990, as indústrias de alta tecnologia têm sido implantadas preferencialmente no eixo 4, ao longo da rodovia Adhemar de Barros/SP-340, devido à localização desses centros de alta tecnologia. A ocupação urbana nesses vetores é espraiada, devido, principalmente, à instalação dessas grandes áreas que abrigam instituições, além da existência de uma produção agrícola e, acima de tudo, considerando o alto valor da terra (CAIADO; PIRES, 2006, p. 282-284).

\footnotetext{
${ }^{117}$ Silva (2008, p. 82-84) discute sobre a lógica regional do território, onde as localizações se organizam a partir dos eixos rodoviários para a implantação dos condomínios e loteamentos fechados na RMC, processo que também pode ser verificado para implantação das Habitações de Interesse Social, a despeito de se acreditar que os motivos que levam a esse tipo de ocupação sejam diferentes em cada um dos casos. Como colocado por Maricato (1995; 2011c), Bonduki (2008) e Ferreira (2003), o elemento fundamental da localização das HIS é o valor da terra.

${ }^{118}$ Os vetores 3, 4 e 5 articulam-se entre si por meio da Rodovia Dom Pedro I.
} 
No vetor 3 , que conecta Campinas aos municípios de Paulínia, Cosmópolis, Artur Nogueira e Engenheiro Coelho por meio da rodovia Professor Zeferino Vaz (SP-332), pode-se observar a implantação da REPLAN em 1972, que impactou na expansão urbana desse vetor, com característica popular, principalmente nos municípios de Paulínia e Cosmópolis. A partir dos anos 1990, observam-se diversos empreendimentos "fechados", principalmente em Paulínia, na área que faz divisa com Campinas (CAIADO; PIRES, 2006, p. 282-284; FREITAS, 2008).

Pode-se observar no Mapa 33 (p. 181) que o vetor 3 apresenta um tecido urbano mais denso até o município de Paulínia e a partir dele, no sentido de Cosmópolis e Engenheiro Coelho, há uma maior descontinuidade. Em relação às Habitações de Interesse Social, também se podem notar: 1) os maiores aglomerados com empreendimentos de diferentes períodos localizam-se em Paulínia; 2) alguns empreendimentos mais recentes em Paulínia, verticalizados, mais próximos do eixo rodoviário; 3) seguindo o vetor no sentido do interior, as Habitações de Interesse Social estão mais dispersas pelos tecidos urbanos; percebe-se que a lógica de implantação se orienta a partir dos centros urbanos nesses municípios de menor porte.

O vetor 4 (Mapa 31, p. 174) conecta parte de Campinas a Jaguariúna, Holambra, Santo Antônio de Posse e Pedreira. Esses municípios pequenos se ligavam à dinâmica regional até os anos 1980 por meio da agricultura, com exceção de Pedreira, que apresenta como destaque a indústria cerâmica. Suas áreas urbanizadas caracterizavam-se por "um tecido urbano típico de cidade interiorana" (PIRES, 2007, p. 34). Nesse vetor, pode-se notar uma maior descontinuidade no tecido urbano, com municípios com pequenas áreas urbanizadas nas quais as implantações das Habitações de Interesse Social podem ser observadas a partir de relações com os pequenos centros, com exceção de Pedreira, onde algumas HIS localizam-se ao longo dos eixos rodoviários (Mapa 33, p. 181).

A conexão entre os distritos de Sousas e Joaquim Egídio (Campinas) e parte de Valinhos à Itatiba por meio da rodovia Dom Pedro I configura o vetor 5 (Mapa 31), cujos destaques são a qualidade paisagística, os importantes aquíferos e as áreas de patrimônio histórico, como as antigas fazendas de café. Tais características propiciaram o parcelamento para fins urbanos de diversas fazendas, com lotes grandes, voltados às camadas de renda alta (PIRES, 2007, p. 34-35). Pode-se, portanto, observar um tecido urbano bastante descontínuo nesse vetor, onde grandes lotes realizados em áreas rurais são permeados por vazios. Ao longo desse eixo, nos municípios de Campinas (distritos de Sousas e Joaquim 
Egídio) e de Valinhos, não se observa a implantação de Habitações de Interesse Social, enquanto em Itatiba há uma maior quantidade delas (Mapa 33, p. 181).

Como a análise realizada por Pires (2007) ocorreu antes da inclusão de Morungaba na Região Metropolitana de Campinas, houve necessidade de incluir mais um vetor, que será aqui denominado de vetor $5 B$.

Mapa 32 - Vetores de Expansão da RMC (incluindo Morungaba)

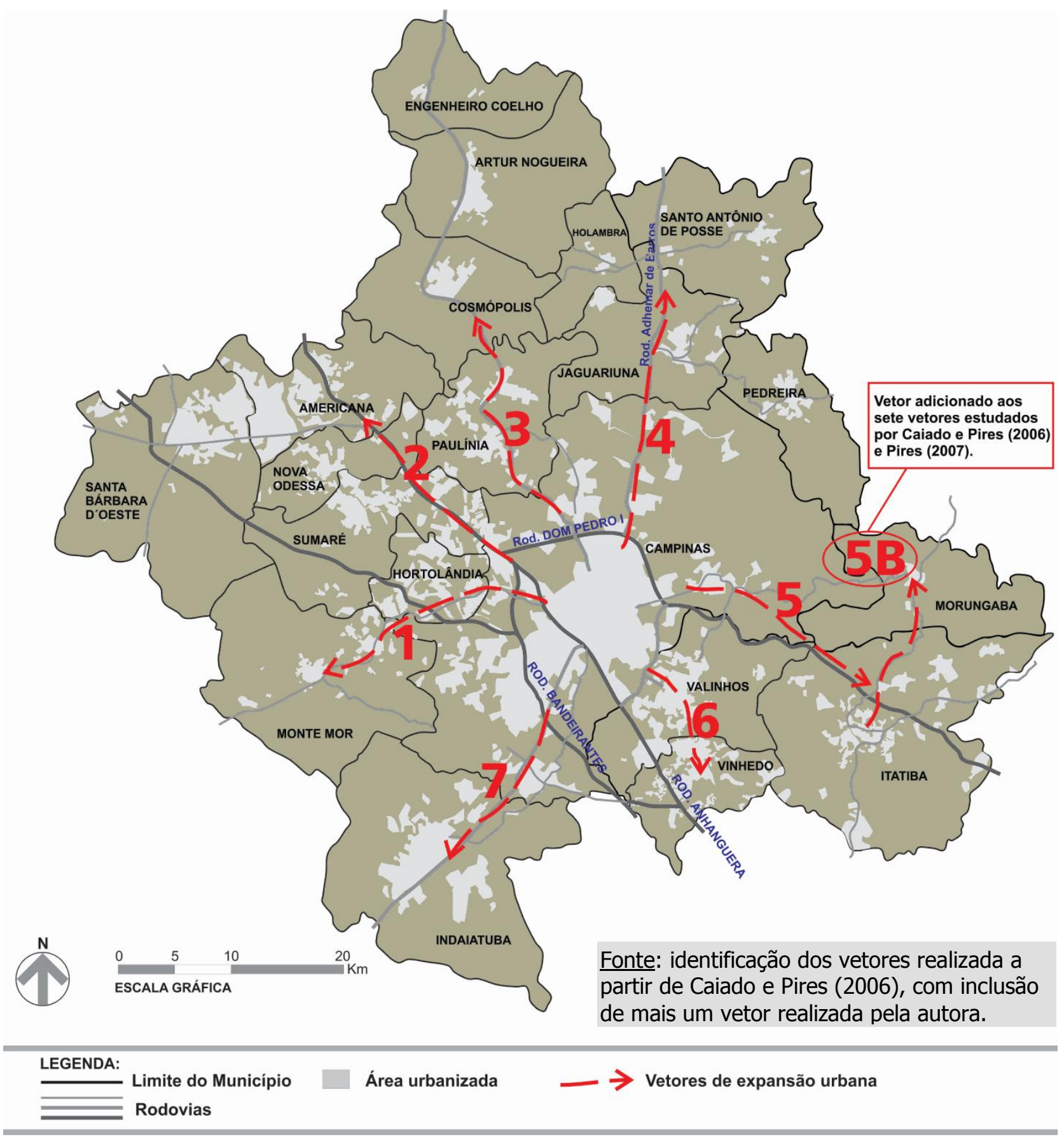


O vetor 5B conecta Itatiba, por meio da SP-360, ao município de Morungaba, conforme Mapa 32. Nele pode-se observar semelhanças com o vetor 5, pois se tem uma área urbanizada bastante descontínua, cujo destaque é a qualidade paisagística e os acidentes topográficos. Em Morungaba, percebe-se uma ocupação territorial antiga e que passou por um pequeno processo de expansão, o que reflete na implantação das HIS. Foram então realizados alguns conjuntos de Habitações de Interesse Social no pequeno núcleo urbano a partir dos anos 1960, conforme Mapa 33 (p. 181).

O vetor 6 (Mapa 31, p. 174) configura-se pelas conexões de Campinas com Valinhos e Vinhedo, cujos principais acessos ocorrem por meio da Av. Francisco de Paula Sousa, de Campinas até Valinhos, e por meio da Via Anhanguera e do anel viário Magalhães Teixeira. No município de Campinas, tem-se uma ocupação de padrão médio e médio-baixo, com um processo de verticalização mais recente, enquanto em Valinhos observa-se um padrão habitacional de condomínios e loteamentos fechados, voltados à classe de maior renda (CAIADO; PIRES, 2006, p. 284). Em Vinhedo, pode-se observar o mesmo tipo de ocupação apontada por Freitas (2008) como um local de dispersão das classes de renda média alta e alta de Campinas.

Pode-se observar no Mapa 33 (p. 181) que o vetor 6 apresenta um tecido urbano praticamente conurbado de Campinas até Vinhedo, onde muitas das Habitações de Interesse Social implantadas apresentam como principal via de acesso a Av. Municipal dos Andradas, que conecta Valinhos a Vinhedo. Enquanto em Vinhedo pode-se notar dois eixos rodoviários que estruturam as HIS: um que seria a ligação com Valinhos por meio da Av. Independência e outro, a rodovia Anhanguera. Observa-se que, nesses municípios, a lógica regional de implantação das HIS prevaleceu sobre a lógica local.

Ao longo da rodovia Santos Dumont/SP-075, que faz a ligação entre Campinas e Indaiatuba, tem-se o vetor 7 (Mapa 31, p. 174). Destaca-se no entorno dessa via uma concentração fabril de importância regional, tendo uma localização estratégica, que apresenta como destaque o Aeroporto de Viracopos, além de se conectar com a região de Sorocaba, articulando-se com as vias Anhanguera e Bandeirantes.

Nesse vetor 7 pode-se observar, no Mapa 33 (p. 181), uma mancha urbana não contínua no sentido de Indaiatuba. Em Campinas, entre as rodovias Anhanguera e dos Bandeirantes, há diversos conjuntos Habitacionais de Interesse Social pequenos, mais verticalizados, sendo a maioria realizada pelos programas Minha Casa Minha Vida e PAR. Após a rodovia dos Bandeirantes, nota-se uma grande aglomeração de conjuntos formada 
principalmente pelos DICs (I ao V) implantados a partir de 1981, além de conjuntos da CDHU. Em Indaiatuba, ao longo do eixo da SP-075, observam-se alguns poucos conjuntos de HIS que se estruturam a partir da proximidade ao eixo 7.

Ao analisar o desenvolvimento urbano e a implantação das Habitações de Interesse Social nos sete vetores de expansão urbana da Região Metropolitana de Campinas, foi possível perceber o papel estruturador dos eixos rodoviários, principalmente nos municípios maiores e naqueles localizados ao longo da rodovia Anhanguera. Nessa lógica de ocupação territorial, ficou evidente a dispersão urbana, apontada por Reis (2006) e Mitica (2007), onde as áreas urbanizadas são intercaladas por vazios urbanos. Foi possível notar que, assim como os condomínios e shoppings são grandes equipamentos fechados que muitas vezes não mantêm relações diretas com as áreas adjacentes e localizam-se distantes dos centros urbanos, em uma lógica de tecido urbano disperso, as Habitações de Interesse Social também estão em sua maioria, na RMC, implantadas em locais distantes das áreas centrais dos municípios e, quase sempre, são intercaladas por vazios urbanos. Os motivos que levaram a essas localizações são diferentes: enquanto as HIS ocupam áreas desprezadas pelo mercado imobiliário, os condomínios e loteamentos buscam a proximidade aos eixos rodoviários, de modo que os deslocamentos regionais sejam facilitados. A despeito de motivos diversos, eles resultam em ocupações territoriais semelhantes e que acarretam os mesmos problemas urbanos.

Cabe lembrar que, nas áreas que sofreram um processo de urbanização mais intenso, como é o caso dos vetores 2 e 6 da RMC, as HIS parecem não se localizar em áreas tão isoladas, permeadas por vazios. No entanto, o processo de ocupação dessas áreas foi o mesmo dos outros vetores - a princípio, as HIS eram distantes das áreas urbanizadas, sem infraestrutura adequada e com poucos serviços e comércios, e mesmo que o crescimento urbano tenha "atingido" essas áreas, elas se desenvolveram com tais características e permaneceram com pouca diversidade funcional e apresentando dificuldades de acesso a equipamentos urbanos mais qualificados e a locais com maior oferta de empregos formais. 


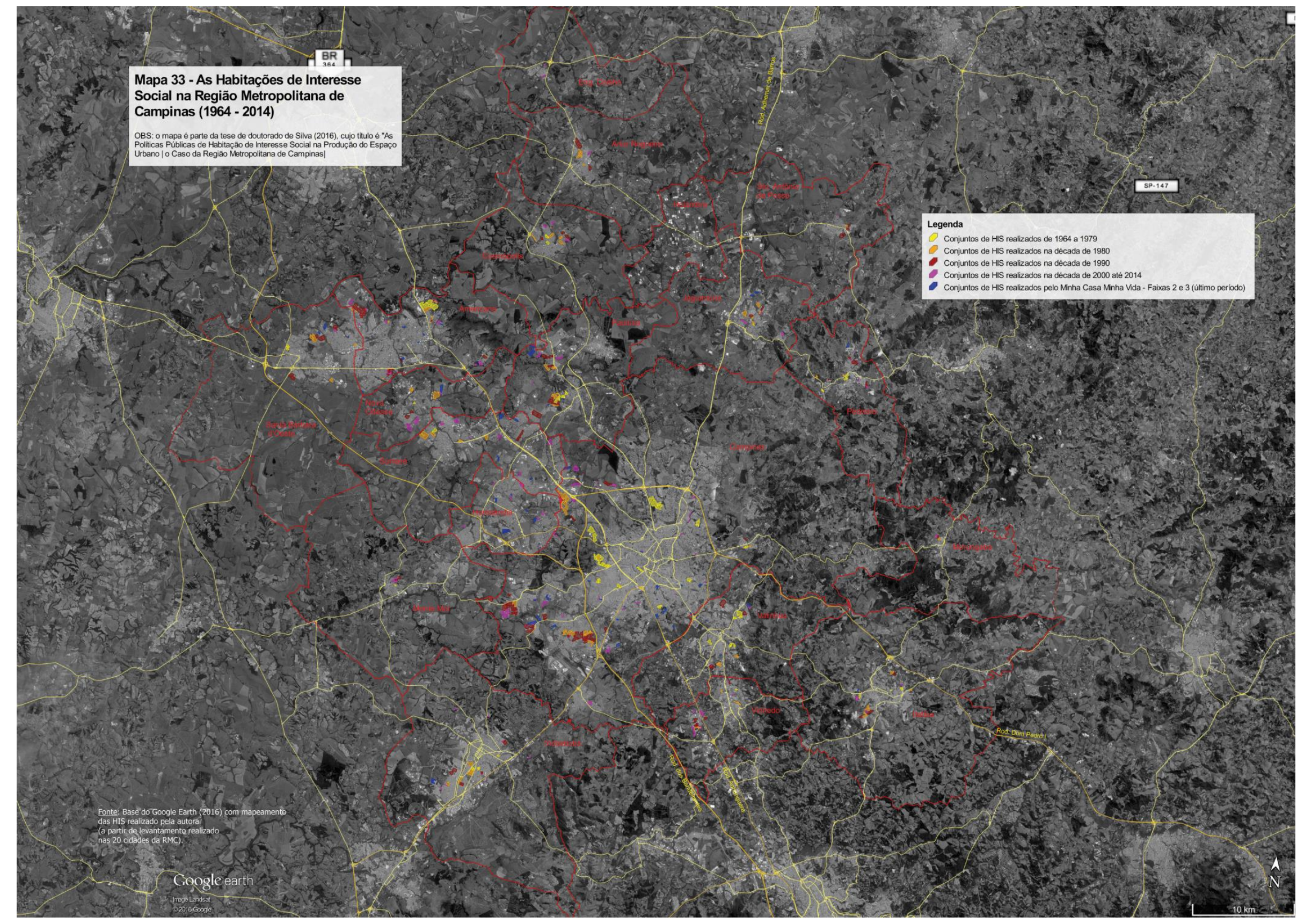


Para que fosse possível discutir as relações entre a localização das Habitações de Interesse Social e a estruturação urbana e metropolitana da região de Campinas, foram identificados, também em mapa, alguns elementos urbanos associáveis a esse processo de segregação: aterros sanitários, estações de tratamento de esgoto e áreas contaminadas ambientalmente (por indústrias e por resíduos sólidos). Esses elementos representam as "zonas de sacrifício"119, ou seja, locais onde se localizam as diversas atividades que causam "incômodos" às áreas vizinhas.

"A expressão 'zonas de sacrifício' é utilizada pelos movimentos de justiça ambiental para designar localidades em que observa-se uma superposição de empreendimentos e instalações responsáveis por danos e riscos ambientais" (VIÉGAS, 2006, p. 1). Uma vez que seu entorno apresenta valor da terra relativamente mais baixo, tanto atraem a localização de moradores de baixa renda, quanto novas instalações desse tipo tendem a ser implantadas nas áreas de moradia de baixa renda, pelo menor acesso dos moradores aos processos decisórios.

Para a observação do desenvolvimento desse processo na Região Metropolitana de Campinas, foi elaborado o Mapa 34 (p. 184), no qual se pode observar a localização das Habitações de Interesse Social realizadas entre 1964 e 2014, a partir do levantamento realizado na pesquisa, assim como a localização das chamadas "zonas de sacrifício". Os seguintes elementos urbanos que representam incomodidade ou insegurança foram localizados: aterros sanitários ${ }^{120}$, estações de tratamento de esgoto ${ }^{121}$, áreas contaminadas ambientalmente ${ }^{122}$ por indústrias ou por resíduos sólidos. Entre esses elementos, incluíram-

\footnotetext{
119 O conceito "Zonas de Sacrifício" tem origem nos anos 1980, nos EUA, momento em que os movimentos sociais apresentaram diversas denúncias referentes à relação entre segregação racial e a localização de empreendimentos de alto impacto ambiental, como aterros sanitários ou estações de tratamento de esgotos (ACSELRAD apud SILVA; BUENO, 2013).

${ }^{120}$ Quanto aos aterros sanitários, a informação referente à destinação dos resíduos foi obtida no Plano Diretor de Gestão de Resíduos da RMC (2009), assim como as localizações desses aterros. Em alguns casos, por meio de pesquisa do nome do aterro no Google Earth, foi realizada a identificação do local, a qual foi checada com a ferramenta Street View. No total, foram mapeados os sete aterros sanitários ativos na RMC.

${ }^{121} \mathrm{Em}$ relação às Estações de Tratamento de Esgoto (ETES), as localizações foram obtidas nos sites das prefeituras dos municípios da RMC ou nas agências específicas (SABESP, DAE, SANASA e SANEBAVI). Como essas informações estavam dispersas, não foi possível identificar todas as ETEs, e no total foram mapeadas 25 ETEs. Cabe lembrar que, embora o levantamento das ETEs tenha sido parcial, elas foram identificadas em municípios pequenos, médios, grandes e na sede da metrópole, de modo que não representa prejuízo à análise.

Foram mapeadas as Estações de Tratamento de Esgoto dos seguintes municípios: Americana (1), Campinas (as 7 maiores), Holambra (1), Indaiatuba (1), Itatiba (1), Jaguariúna (1), Monte Mor (3), Nova Odessa (1), Paulínia (1), Pedreira (1), Santa Bárbara d'Oeste (4), Santo Antônio de Posse (1), Valinhos (1) e Vinhedo (2).

${ }^{122}$ As áreas ambientalmente contaminadas foram identificadas a partir do relatório de áreas contaminadas do Estado de São Paulo da CETESB (Companhia Ambiental do Estado de São Paulo). No total, foram mapeadas 17 áreas contaminadas por meio de resíduos sólidos e 102 áreas contaminadas por atividade industrial, considerando as áreas contidas nos 20 municípios da RMC.
} 
se também as instituições prisionais ${ }^{123}$, porque, no contexto brasileiro, tendem a atrair a criminalidade e insegurança para seu entorno.

No Mapa 34, esses elementos são identificados por marcadores pontuais, conforme as cores: amarela - aterros sanitários; azul clara - estações de tratamento de esgoto (ETEs); roxa - penitenciárias e similares; verde - áreas ambientalmente contaminadas por resíduos sólidos; e rosa - áreas contaminadas por atividade industrial. Desse modo, foi possível identificar as relações entre esses elementos e a implantação das Habitações de Interesse Social na Região Metropolitana de Campinas.

${ }^{123}$ Em relação aos sistemas prisionais, foram identificadas e mapeadas sete unidades - em Campinas: um Centro de Progressão Penitenciária, uma penitenciária feminina e uma Fundação Casa; em Hortolândia: duas penitenciárias; em Americana: um Centro de Detenção Provisória e em Sumaré: um Centro de Ressocialização e anexo de regime semiaberto. As informações sobre a localização foram obtidas no site da Secretaria de Administração Penitenciária do Estado de São Paulo. 


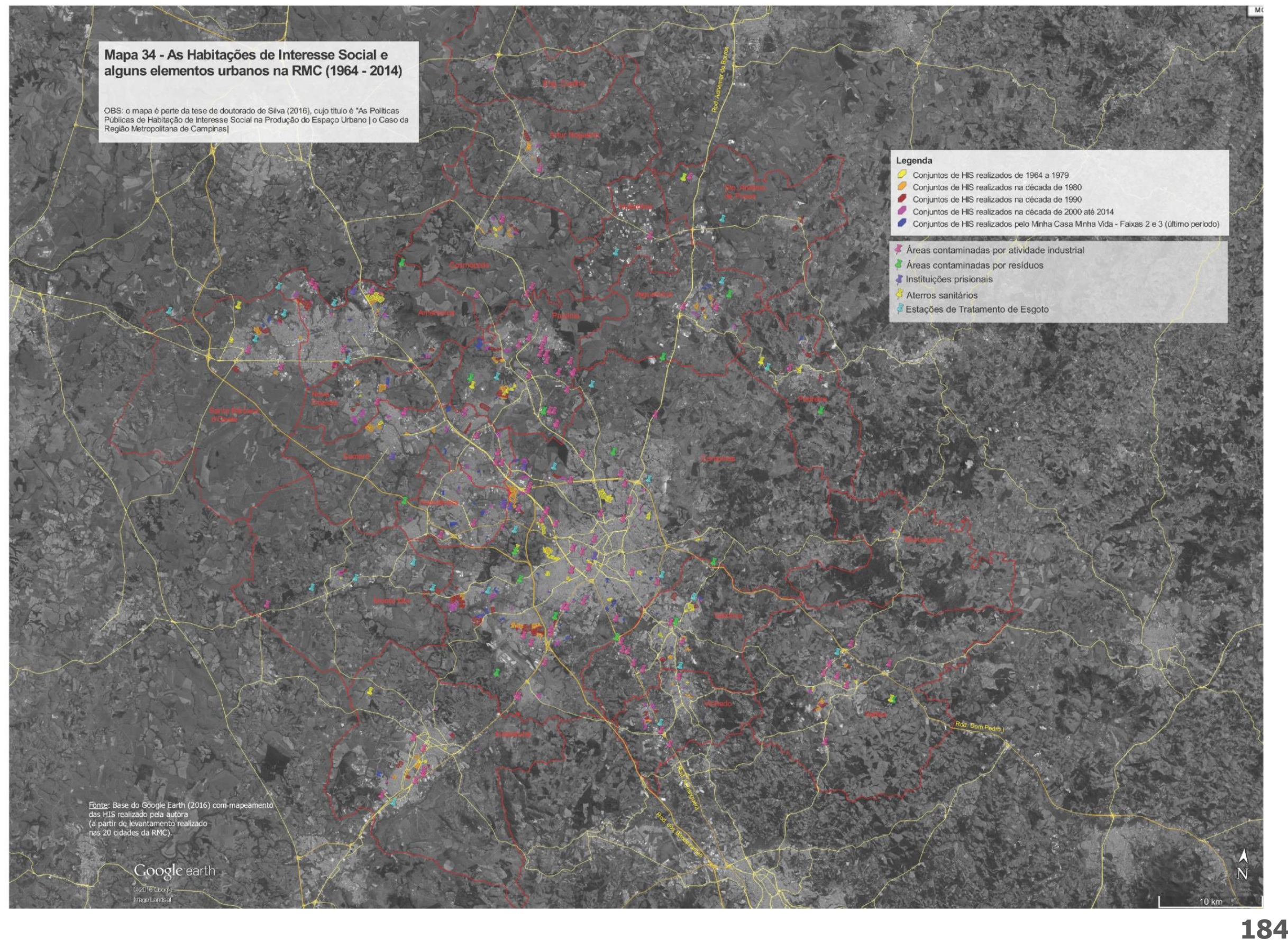


A partir da análise do Mapa 34 (p. 184), em relação à localização dos aterros sanitários, percebe-se que nos municípios que possuem uma pequena área urbanizada em relação ao perímetro urbano, como nos casos de Indaiatuba, Itatiba e Santo Antônio de Posse, eles situam-se bem distantes do tecido urbano. Nos outros municípios - Campinas e Paulínia -, pelas características intrínsecas aos aterros, eles também não estão inseridos no tecido urbano, entretanto, pode-se notar uma localização não tão distante das áreas urbanizadas, estando no mesmo vetor da cidade onde se situam predominantemente as Habitações de Interesse Social. Em Pedreira, embora o aterro não esteja no vetor onde se percebe a maioria das HIS, ele está próximo de alguns conjuntos de HIS, pois a questão topográfica específica desse município configurou um tecido urbano longínquo e espraiado.

Quanto às ETEs, nos casos de Indaiatuba, Itatiba, Monte Mor, Holambra e Santo Antônio de Posse, elas não apresentam relação com a implantação das HIS, sendo que no último município a ETE está bem distante da área urbanizada. Em todos os outros municípios em que foram mapeadas as ETEs, percebe-se uma proximidade grande ou com alguns conjuntos de HIS ou com áreas de concentração, como nos casos de Paulínia e Valinhos. Em Campinas e Santa Bárbara d'Oeste, que apresentam várias ETES, na primeira cidade foi possível notar que a maioria delas está próxima ou no vetor sudoeste, onde se concentra a maioria das HIS; na segunda cidade há duas ETEs distantes do tecido urbano e duas inseridas nele, e entre aquelas que se localizam no tecido urbano, uma apresentou-se próxima às HIS e a outra, em área adjacente a conjuntos de HIS. Cabe ainda destacar o caso de Nova Odessa, onde se percebe que a ETE situa-se próxima a uma área de aglomeração de HIS do município de Americana, ou seja, é possível identificar uma estruturação regional do território (ver Mapa 34 - As Habitações de Interesse Social na RMC e alguns elementos estruturadores do espaço urbano, p. 184).

Em relação às localizações dos institutos prisionais, pode-se perceber no Mapa 34 (p. 184) que, considerando as sete unidades levantadas, apenas uma não apresenta uma relação direta entre sua localização e a das Habitações de Interesse Social (HIS): o caso de Sumaré, cujo Centro de Ressocialização apresenta-se em área isolada, bastante distante da área urbanizada. Em Campinas, a penitenciária feminina está ao lado de dois conjuntos de HIS: o conjunto Júlio de Mesquita (de 1974), com um extenso perímetro, e um conjunto Minha Casa Minha Vida de 2014. Nesse caso é interessante observar o processo dialético de ocupação territorial, pois o conjunto foi implantado em 1974, suscitando uma estruturação 
urbana que corroborou a implantação do presidio ${ }^{124}$ em 1976, e ambos, por sua vez, proporcionaram a implantação de outro conjunto habitacional em 2014.

Cabe destaque às duas grandes penitenciárias de Hortolândia e ao Centro de Progressão Penitenciária de Campinas, pois eles configuram um grande perímetro e estão localizados próximos a áreas de concentração de HIS tanto do município de Campinas quanto de Hortolândia. Observa-se, ainda, a Fundação CASA Campinas, também próxima a uma concentração de conjuntos de HIS que se estende por Campinas, Sumaré e Hortolândia. Portanto, reforçando o padrão de segregação urbana e, consequentemente, demarcando uma estruturação urbano regional, localizam-se na mesma região as duas penitenciárias de Hortolândia, o Centro de Progressão Penitenciária de Campinas, a fundação CASA Campinas, o aterro sanitário de Campinas e a maioria das ETEs de Campinas.

Quanto às áreas contaminadas por resíduos, pode-se perceber que, nos municípios de Hortolândia, Itatiba, Jaguariúna, Pedreira e Santo Antônio de Posse, elas estão distantes da área urbanizada do município, pois apresentam uma pequena área urbanizada em relação ao perímetro. Em Americana, observa-se uma área contaminada e, embora distante da área urbanizada, está no mesmo vetor nordeste, onde há uma área de concentração de HIS. Em Paulínia, uma área contaminada está próxima à rodovia Zeferino Vaz, enquanto a outra está próxima às duas áreas de concentração de HIS. No município de Valinhos, podem-se notar três áreas contaminadas, uma na área central, uma distante do tecido urbanizado, próxima à rodovia Anhanguera, e uma terceira um pouco distante da área urbanizada, mas no vetor nordeste, onde há uma concentração de HIS, além da ETE. Em Campinas, há seis áreas de contaminação por resíduos, e quatro delas estão no vetor sudoeste, onde se concentra a maioria das HIS, além de outros elementos estruturadores, como já discutido (ver Mapa 34, p. 184).

Em alguns municípios, conforme Mapa 34 (p. 184), não se pode perceberuma relação direta entre as áreas contaminadas por indústrias e a implantação das HIS: em Artur Nogueira, Monte Mor, Holambra e Santo Antônio de Posse, onde essas áreas estão próximas às principais rodovias; em Itatiba, Hortolândia e Santa Bárbara d'Oeste, em que as áreas contaminadas estão mais inseridas no tecido urbano, mas não apresentam relação direta com o local das HIS, e em Paulínia, que se apresenta como um caso isolado, pois, devido à refinaria REPLAN, as áreas contaminadas concentram-se em suas imediações.

124 A penitenciária feminina de Campinas foi inaugurada em 1993, mas anteriormente havia no local uma ocupação com uso semelhante, o presídio São Bernardo, desde 1976. 
Em outros municípios, como Indaiatuba, Pedreira, Sumaré, Valinhos e Vinhedo, podem-se notar algumas relações entre a localização das áreas contaminadas por indústrias e a das HIS. Em Indaiatuba, a maioria dessas áreas está ao longo da principal rodovia, destacando uma ocupação mais intensa no trecho próximo à região de predomínio das HIS; em Pedreira, essa área está mais inserida no tecido urbano e próxima de alguns conjuntos de HIS; em Sumaré, as duas áreas contaminadas situam-se próximas a conjuntos de HIS; em Valinhos e Vinhedo, a maioria dessas áreas está ao longo da rodovia Anhanguera, entretanto, as áreas mais inseridas no tecido urbano localizam-se próximas às HIS.

Destacam-se quatro municípios cujas áreas contaminadas por indústrias relacionamse com a localização das HIS: Americana, Cosmópolis, Nova Odessa e Campinas. Em Americana, há três áreas contaminadas e, em área próxima a cada uma delas, há uma aglomeração de HIS; em Cosmópolis, a área contaminada é adjacente a um grande conjunto habitacional; em Nova Odessa, a lógica de estruturação urbana se estende aos municípios vizinhos e pode-se perceber a área contaminada próxima a conjuntos de Nova Odessa e Sumaré; em Campinas, há várias áreas dispersas pela cidade, mas a maioria delas pode ser observada no vetor sudoeste - nordeste, onde se destacam vários outros elementos estruturadores, além de ser o local de predomínio de implantação das HIS.

Após as análises da localização das Habitações de Interesse Social na Região Metropolitana de Campinas, segundo os vetores de expansão urbana (Mapa 33, p. 181) e os locais em que se configuram as zonas de sacrifício (Mapa 34, p. 184), pode-se perceber que a presença das Habitações de Interesse Social se mantém, em sua maioria, nos vetores de expansão urbana da RMC mais conurbados, com uma relação maior com os eixos rodoviários. Ressalta-se, ainda, que, de modo geral, as HIS foram observadas em áreas distantes dos centros dos municípios e em locais adjacentes a implantações de caráter metropolitano desagradáveis ao convívio urbano (como aterros sanitários, penitenciárias e grandes infraestruturas), locais "rejeitados" pelo mercado imobiliário. 


\section{Considerações Finais}

Os capítulos iniciais da presente pesquisa apresentam um quadro histórico da política habitacional no país, o processo de expansão e consolidação da Região Metropolitana de Campinas e o tratamento dado à questão da habitação nas legislações municipais. A partir disso, organiza-se um pano de fundo com o qual se torna possível observar os mapeamentos realizados (apresentados no Capítulo IV) e esmiuçar o papel das políticas e instrumentos do campo da habitação e do urbanismo na configuração do espaço urbano na Região Metropolitana de Campinas.

A partir das análises dos instrumentos voltados às Habitações de Interesse Social presentes nos planos diretores, os municípios da RMC foram classificados em três grupos, conforme a inserção desses instrumentos em seus planos. Pode-se então perceber, no Capítulo II, que o grupo de municípios com poucos instrumentos para HIS coincide com aqueles que não apresentam os três itens para obtenção de recursos do FNHIS (Fundo Nacional de Habitação de Interesse Social): as leis de fundo, de conselho de habitação e os Planos Locais de Habitação de Interesse Social (PLHIS).

As produções de Habitação de Interesse Social realizadas entre 1964 e 2014 nos municípios da RMC foram apresentadas no Capítulo III, e esses municípios foram analisados considerando a relação entre o percentual de HIS e o total de domicílios urbanos. A partir desses percentuais da produção de HIS e a classificação dos municípios, conforme os instrumentos para HIS, foi possível perceber que a presença dos instrumentos urbanísticos nos planos diretores, especialmente as ZEIS, corroboram um contexto favorável para a produção de HIS, mas, por outro lado, não são determinantes dessa produção, pois, tomando como base os dados analisados, percebe-se que a ausência deles não diminui a produção de HIS.

Em relação à implantação dessas HIS no território urbano, a indicação nos mapas com cores distintas por período (década) facilita que se visualize o processo no tempo. Evidencia o quanto a implantação desses conjuntos de HIS é elemento muito significativo na estruturação urbana e metropolitana, do mesmo modo que a estruturação presente em determinado momento direciona a localização de novas Habitações de Interesse Social.

Considerando as análises das Habitações de Interesse Social em cada um dos municípios da Região Metropolitana de Campinas, observados individualmente, foi possível perceber cinco tipologias de ocupação dessas HIS no território, conforme análise realizada no Capítulo IV deste trabalho (p. 137 e ss.). A lógica de implantação dessas HIS que 
prevaleceu nos municípios da RMC foi em áreas distantes dos serviços, equipamentos e infraestrutura, às margens das cidades e, na maioria dos municípios, foi possível observar vetores de concentração desse tipo de ocupação.

Discutiu-se, ainda, que as HIS mais recentes, realizadas a partir dos anos 1990, ocorreram em periferias consolidadas, muitas vezes, correspondendo a áreas remanescentes de conjuntos realizados anteriormente. No entanto, mesmo essas periferias apresentando-se mais inseridas no tecido urbano, com alguma diversidade de comércio e serviços, configuraram-se com as características marcantes de seu processo de expansão, a partir de um território precário e fragmentado, com dificuldades de acesso a meios de transporte, centros culturais e de lazer e equipamentos urbanos.

Outra questão importante foi perceber a relação entre os diversos municípios da região metropolitana. Aqueles cuja localização das HIS ocorreu em áreas distantes e com dificuldades de acesso aos serviços e equipamentos urbanos foram os municípios próximos ao principal eixo de deslocamento pendular, a rodovia Anhanguera. Enquanto os outros, que apresentaram uma localização "privilegiada" - com as Habitações de Interesse Social em áreas mais inseridas nos tecidos urbanos, com melhor acesso aos serviços urbanos -, apresentaram-se como periferia da região metropolitana.

A partir da análise realizada por vetores de expansão urbana da RMC, foi possível perceber o papel fundamental dos eixos rodoviários, cuja lógica de ocupação é parte do processo de dispersão urbana que pode ser identificado na região, onde as áreas urbanizadas são intercaladas por vazios urbanos. As Habitações de Interesse Social podem, então, ser compreendidas nesse processo de urbanização dispersa, onde há uma forte relação entre suas localizações e os eixos rodoviários, principalmente percebida nos municípios com maiores áreas urbanizadas da RMC, que apresentam um evidente processo de conurbação (com destaque para o eixo entre Campinas e Americana, ao longo da rodovia Anhanguera).

Cabe destaque, ainda, que, mesmo nos municípios com uma urbanização mais intensa, onde se pode observar essa relação entre a localização das HIS e os eixos rodoviários, elas apresentam as características de precariedade intrínsecas ao processo de expansão do qual resultaram. Portanto, mesmo as Habitações de Interesse Social consideradas "bem localizadas", por estarem de certo modo próximas aos eixos de deslocamento pendular, apresentam-se em tecidos urbanos fragmentados, com pouca diversidade funcional e com dificuldades de acesso tanto aos equipamentos urbanos quanto aos empregos formais. 
A hipótese inicial da presente tese foi de que a política habitacional, expressa pela produção e localização das Habitações de Interesse Social, é fator da maior relevância na estruturação do espaço urbano metropolitano.

Conforme se pode observar nas evidências apontadas no Capítulo IV, essas políticas e instrumentos são tanto responsáveis pela indução quanto pelo reforço de tendências existentes, o que é possível verificar devido à indicação nos mapas com cores distintas por período (década) de implantação das HIS no território urbano da Região Metropolitana de Campinas.

Essa interação entre a indução de novas localizações e o reforço de tendência existente reitera o que Villaça (2001) aponta como o processo de segregação que domina esse processo de estruturação urbana.

Nesses termos, para aprofundar a discussão sobre a localização das Habitações de Interesse Social e a estruturação urbana e metropolitana da região de Campinas, foram localizados, no Mapa 34 (p.184), elementos urbanos que podem ser relacionados a esse processo de segregação: incomodidade como aterros sanitários, estações de tratamento de esgoto e áreas contaminadas ambientalmente (por indústrias e por resíduos sólidos), além das instituições prisionais, que no caso brasileiro, tendem a atrair criminalidade para o seu entorno. Esses elementos são coerentes com o que ficou conhecido como "zonas de sacrifício", expressão utilizada para descrever locais que abrigavam atividades de grande poluição, contaminação, incômodo ou periculosidade.

Villaça (2001), ao explicar a estruturação intraurbana de metrópoles brasileiras, recorre ao tema da segregação, observando que o "centro" segue o vetor das zonas de moradia de alta renda, expandindo-se sob a forma de seção de círculo, para onde atrai e concentra investimentos de qualificação urbana. A partir dessa compreensão, mas utilizandose como objeto a localização das Habitações de Interesse Social, foi possível perceber no Mapa 34 (p. 184) a proximidade entre elas e os elementos que representam incomodidade ou periculosidade.

Foi possível discutir, portanto, a partir da localização desses elementos que geram incomodidade - aterros sanitários, Estações de Tratamento de Esgoto, instituições prisionais e áreas contaminadas por indústrias e por resíduos -, que há uma lógica direta entre suas localizações e as das Habitações de Interesse Social, inclusive com as de iniciativa do poder público. Nos municípios que apresentam uma área urbanizada maior, ocupando grande parte do seu perímetro, essas relações aparecem de forma mais intensa, enquanto nos municípios 
com menores áreas, esses elementos característicos das chamadas "zonas de sacrifício" estão mais distantes das Habitações de Interesse Social. A despeito das escalas municipais, em todos os municípios da Região Metropolitana de Campinas observou-se uma relação entre a localização das Habitações de Interesse Social e a dos elementos urbanos que representam incomodidade ou periculosidade.

O Estado tem atuado sobre as cidades, principalmente provendo infraestrutura de água e esgoto, construindo avenidas e habitações, oferecendo e regulamentando o transporte urbano. Desde 1930, segundo Villaça (1999, p. 183), construiu-se uma visão de que, no Brasil, os problemas são decorrentes de um "crescimento caótico - sem planejamento" e, portanto, um planejamento "integrado" (aspas do autor) seria essencial para sanar esses problemas, construindo-se, assim, o conceito da ideologia do planejamento que ainda perdura.

Há décadas nossas classes dominantes vêm desenvolvendo interpretações sobre as origens dos problemas sociais que se manifestam agudamente em nossas cidades - especialmente os de habitação, transportes, saneamento e meio ambiente -, bem como sobre o papel do planejamento urbano na solução desses problemas. Tais idéias visam ocultar as verdadeiras origens daqueles problemas, assim como o fracasso daquelas classes e do Estado em resolvê-los. Com isso a dominação é facilitada (VILLAÇA, 1999, p. 183).

Assim, a estruturação do espaço pode ser percebida como um importante instrumento de dominação sobre os mais pobres.

A reprodução das relações de produção, a acumulação de capital, entre outras questões colocadas pelo capitalismo, para Gottdiener (1997, p. 195-198), não devem mais ser analisadas como se ocorressem no espaço, conforme apresentaram os marxistas; diferentemente, são sobre o espaço.

Como coloca Harvey (2014), a classe dominante controla os processos de urbanização interferindo diretamente nas políticas de Estado, inclusive estimulando estilos de vida entre os mais pobres, pois a cidade é o espaço para se consumir o excedente de produção do capital.

A reprodução do capital passa por processos de urbanização de inúmeras maneiras. Contudo, a urbanização do capital pressupõe a capacidade de o poder de classe capitalista dominar o processo urbano. Isto implica a dominação da classe capitalista não apenas sobre os aparelhos de Estado (em particular, as instâncias do poder estatal que administram e governam as condições sociais e infraestruturais nas estruturas territoriais), como também sobre populações inteiras - seus estilos de vida, sua capacidade de trabalho, seus valores culturais e políticos, suas visões de mundo (HARVEY, 2014, p. 133). 
Dessa forma, as políticas públicas habitacionais, conforme materializadas no espaço, acabam por controlar a localização de moradia dos mais pobres em determinadas áreas da cidade, configurando a estruturação urbana.

Em síntese, a partir da hipótese de que a política habitacional expressa pela produção e localização da Habitação de Interesse Social é fator da maior relevância na estruturação do espaço urbano metropolitano, a pesquisa conclui que, conforme se pode observar nas evidências apontadas no Capítulo IV, essas políticas e instrumentos são tanto responsáveis pela indução quanto pelo reforço de tendências existentes.

O que se desenvolve neste trabalho não é uma análise do "planejamento", mas do efetivo produto. Na configuração desse produto, somam-se intencionalidades - muitas vezes conduzidas não pelo interesse público ou por argumentos técnicos, mas por inoperâncias do Estado e conflitos internos entre seus diferentes setores e entre esferas de governo, bem como por direcionamentos dados pelo mercado ou por sua associação com a esfera política.

Assim, a principal contribuição da tese é apresentar um retrato do "estado da arte" das políticas e instrumentos existentes e os produtos que consolidam no espaço urbano.

Análises mais profundas poderão ser feitas, mas a tarefa até aqui realizada é justamente a de evidenciar ações/inações e seus produtos, expondo com toda clareza e sólida base empírica a cidade real, produzida por todas as condições consolidadas até este momento histórico. 


\section{Referências}

ALMEIDA, Caliane Christie Oliveira de. Habitação social: origens e produção (Natal, 18891964). Dissertação (Mestrado em Teoria e História da Arquitetura e do Urbanismo) - Escola de Engenharia de São Carlos, Universidade de São Paulo, São Carlos, 2007.

ALVES, Maria Abadia da Silva. Espacialidades, escala e complexidade dos problemas metropolitanos: o caso da Região Metropolitana de Campinas (RMC). Tese (Doutorado em Economia Aplicada) - Instituto de Economia da Unicamp, Campinas, 2007.

ARANTES, Pedro Fiori e FIX, Mariana. Os paradoxos do Programa Minha Casa, Minha Vida. Revista eletrônica Correio da Cidadania julho de 2009. http://www.correiocidadania.com.br/index.php?option=com content\&view=article\&id=3576: pcthabitacional310709\&catid=66:pacote-habitacional\&Itemid=171

ARRETCHE, Marta Teresa da Silva. Políticas de Habitação para a população de baixa rende e saneamento básico. Campinas: NEPP/Unicamp, 1994.

AZEVEDO, Sérgio de; ANDRADE, Luís Aureliano Gama de. Habitação e poder: da fundação da casa popular ao Banco Nacional de Habitação. Rio de Janeiro: Zahar Editores, 1982.

BAENINGER, Rosana. Região Metropolitana de Campinas: expansão e consolidação do urbano paulista. In: HOGAN; Daniel Joseph; CUNHA, José Marcos Pinto; BAENINGER, Rosana; CARMO, Roberto Luiz. (Org.). Migração e Ambiente nas Aglomerações Urbanas. Campinas, SP: MPC Artes Gráficas em Papel, 2001, pp. 320-348.

. Região, metrópole e Interior: espaços ganhadores e espaços perdedores nas migrações recentes - Brasil, 1980-1996. Tese (Doutorado em Sociologia) - Instituto de Filosofia e Ciências Humanas - IFCH, Unicamp, Campinas, 1999.

. Regionalização e Migração em São Paulo: Características dos Anos 80. In: Anais VII ANPUR, 1997, Recife, vol. 2, pp. 995 - 1013.

BARROS, João Manoel Scudeler. Espacialidade contemporâneas da esfera da vida pública - estudos de caso do município de Hortolândia. Dissertação de Mestrado (pós graduação em Urbanismo), Pontifícia Universidade Católica, Campinas: 2008.

BOLAFFI, Gabriel. Aspectos sócio-econômicos do Plano Nacional de Habitação. São Paulo: FAU-USP, 1975.

. Habitação e Urbanismo: o problema e o falso problema. In: MARICATO, Erminia (Org.). A produção capitalista da casa (e da cidade) no Brasil industrial. $2^{a}$ ed., São Paulo: Editora Alfa-omega, 1982.

BONDUKI, Nabil. Do Projeto de Moradia ao Programa Minha Casa Minha Vida: Revista Teoria e Debate no 82, maio/junho, 2009.

- Habitação econômica promovida pelos IAPs e IPESP em São Paulo, no período de 1930 a 1964. São Paulo: 1998 (mimeo). 1998.

Origens da habitação social no Brasil. São Paulo: Editora Estação Liberdade, 
Política habitacional e inclusão social no Brasil: revisão histórica e novas perspectivas no governo Lula. Revista eletrônica Arquitetura e Urbanismo, 2008.

BRANCO, Camila Antonia Pereira Moreira. Habitação de Interesse Social: Projeto Arquitetônico e Projeto de Urbanismo. 61 pp. Trabalho final de graduação - Curso de Arquitetura e Urbanismo da Universidade São Francisco, Itatiba, 2013.

BRASIL. Estatuto da Cidade (2002). Estatuto da Cidade: Guia para Implementação pelos Municípios e Cidadãos: Lei no 10.257 de 10 de julho de 2001, que estabelece direitrizes gerais da política urbana. - $2^{a}$ edição - Brasília: Câmara dos Deputados, coordenação de publicações, 2002.

BUENO, Laura Machado de Mello; CYMBALISTA, Renato (orgs.). Planos Diretores Municipais: novos conceitos de Planejamento Territorial. São Paulo: Annablume, 2007.

CAIADO, Maria Célia da Silva. O padrão de urbanização brasileiro e a segregação espacial da população na Região de Campinas: o papel dos instrumentos de gestão urbana. In: Anais do XI Encontro Nacional de Estudos Populacionais da ABEP, pp. $457-488$, 1998.

CAIADO, Maria Célia da Silva; PIRES, Maria Conceição Silvério. Campinas metropolitana: transformações na estrutura urbana atual e desafios. In: CUNHA, J. M. P. da (Org.). Novas metrópoles paulistas: população, vulnerabilidade e segregação. Campinas: Nepo/Unicamp, 2006.

- O verso e o reverso da dinâmica metropolitana: mobilidade populacional e estruturação socioespacial. In: XIV Encontro Nacional de Estudos Populacionais. Caxambu. 2006.

CALDAS, Nisimar Martinez Pérez. Os novos instrumentos da Política Urbana: alcance e limitações das ZEIS. Tese de doutorado, FAU-USP, São Paulo, 2009.

CALDEIRA, Teresa Pires do Rio. Enclaves Fortificados: a nova segregação urbana. Novos Estudos CEBRAP, n 47, p. 179-192, mar. 1992.

CANO, Wilson \& BRANDÃO, Carlos A (coords.). A Região metropolitana de Campinas: urbanização, economia, finanças e meio ambiente. Campinas: Editora da UNICAMP, 2002. $2 v$.

CANO, Wilson e SEMEGHINI, Ulysses. Cidade, Urbanização, desenvolvimento econômico e entidades regionais: reflexões sobre a experiência paulista. São Paulo, 1992, seminários FUNDAP "A Nova Organização do Estado de São Paulo: subsídios para um modelo de gestão", pp. 23-33.

CARDOSO, Adauto Lucio (Org.) O Programa Minha Casa Minha Vida e seus Efeitos Territoriais. Rio de Janeiro: Letra Capital, 2013.

CARDOSO, Adauto L.; Aragão, Thêmis A.; ARAÚJO, Flávia S. Habitação de Interesse Social: política ou mercado? Reflexos sobre a construção do espaço metropolitano. In: Anais do XIV ENANPUR. Rio de Janeiro: 2011.

CARVALHO, Lygia Nunes. As políticas públicas de localização da habitação de interesse social induzindo a expansão urbana em Aracaju - SE. Dissertação (Mestrado em Planejamento Urbano e Regional) - Faculdade de Arquitetura e Urbanismo, Universidade de São Paulo, São Paulo, 2013. 
COMARU, Francisco; MORETTI, Ricardo de Sousa. Diretrizes para Planos de Uso e Ocupação em Áreas Delimitadas como Zonas Especiais de Interesse Ambiental (ZEIA) e Zonas de Interesse Social (ZEIS). In: DENALDI, Rosana. (Org.). 0 Desafio de Planejar a Cidade. São Paulo: Annablume, v. 1, p. 271-291, 2012,.

CONSTANTINO, Lygia Gonçalves. Habitação Popular em Campinas: ação e identidade. Tese de doutorado, FAU-USP, São Paulo, 1997.

COUTINHO, L. G. e SUZIGAN, W. (coords.). Mudança tecnológica e desenvolvimento regional nos anos 90: da interiorização do desenvolvimento à nova dimensão espacial da indústria paulista Campinas. FECAMP, relatório final, 1993.

CRUZ, Maristela Miranda. Política Habitacional em Sumaré: Favela São Domingos. Dissertação (Mestrado em Urbanismo), Centro de Ciências Exatas, Ambientais e de Tecnologias, Pontifícia Universidade Católica, Campinas, 2008.

CUNHA, José Marcos Pinto; FONSECA, Rinaldo Barcia (coords). Núcleo de Estudos de População (NEPO) e Núcleo de Economia Social, Urbana e Regional (NESUR). Atlas da Região Metropolitana de Campinas. Campinas Metropolitana: diversidades sócioespaciais. Campinas: Unicamp, julho de 2004. 1 CD-Room. Disponível em: <http://www.unicamp.br/nepo >. Acesso em: 08 de jan. 2007.

CUNHA et al. Expansão Metropolitana, Mobilidade Espacial e Segregação nos anos 90: o caso da RM de Campinas. In: XI ENCONTRO NACIONAL DA ASSOCIAÇÃo DE PóSGRADUAÇÃO E PESQUISA EM PLANEJAMENTO URBANO E REGIONAL - XI ENA da ANPUR. Maio de 2005, Salvador. Anais eletrônicos... Salvador: FAUFBA, 2005, 1 CD-ROM. Trabalho apresentado no XI Encontro Nacional de Pós-graduação e Pesquisa em Planejamento Urbano e Regional - ANPUR - 23 a 27 de maio de 2005.

DAL'BÓ, André. Luta social e a produção da cidade. Dissertação de Mestrado, Instituto de Arquitetura e Urbanismo da Universidade de São Paulo, IAU-USP, São Carlos, 2013.

D'OTTAVIANO, Maria Camila L.. Condomínios Fechados na Região Metropolitana de São Paulo: fim do modelo rico versus periferia pobre? Tese de Doutorado, FAUUSP, 2008.

DRAIBE, Sonia Miriam. As políticas Sociais do Regime Militar brasileiro. In: SOARES, Glaucio Dillon; D'ARAUJO, Celina (orgs.). 25 anos de Regime Militar. Rio de Janeiro: FGV, 1994.

DENIZO, Valentina. Os produtos da política habitacional na Região Metropolitana de São Paulo: elementos para análise de uma política metropolitana de habitação. Tese de Doutorado. Universidade de São Paulo, São Paulo, 2007.

EMILIANO, Elisamara de Oliveira. Legislação para Habitação de Interesse Social: estudo de caso do município de Campinas. Dissertação (Mestrado em Urbanismo) - Centro de Ciências Exatas, Ambientais e de Tecnologias, Pontifícia Universidade Católica, Campinas, 2006.

FERNANDES, Florestan. Mudanças Sociais no Brasil: aspectos do desenvolvimento da sociedade brasileira. São Paulo: DIFEL, 1979 (3ª Ed.).

FERREIRA, João Sette Whitaker. São Paulo: o mito da cidade global. Tese de doutorado. São Paulo: USP, 2003. 
FERREIRA, João Sette Whitaker (coord). Produzir Casas ou Construir Cidades? Desafios para um novo Brasil urbano - Parâmetros de qualidade para a implementação de projetos habitacionais e urbanos. São Paulo: LABHAB, FUPAM, 2012.

FINEP-GAP. Habitação popular: inventário da ação governamental. FINEP/RJ, 1985.

FONSECA, Rinaldo Barcia; DAVANZO, Aurea M. Q.; NEGREIROS, Rovena M. C. (orgs.). Livro Verde: desafios para a gestão da Região Metropolitana de Campinas. Campinas: Editora da UNICAMP, 2002. 498 p.: il.

FREITAS, Eleusina L. H. de. Loteamentos Fechados. Tese de doutorado, SP: FA-USP, 2008.

FUNDAÇÃO SEADE "Cenários da Urbanização Paulista", in "Coleção São Paulo no Limiar do Século XXI", 1992, Secretaria de Planejamento e Gestão - Vol. 6, 7 e 8.

HARVEY, David. O direito à cidade. Revista Piauí, Edição 82, julho de 2013.

. O Novo Imperialismo. (Tradução - Adail Sobral e Maria Stela Gonçalves). $2^{a}$ ed., São Paulo: edições Loyola, 2004, 196 p.

- Cidades rebeldes: do direito à cidade à revolução urbana. (Tradução: Jeferson Camargo). São Paulo: Martins Fontes, 2014.

HEIDEMANN, Francisco G.; SALM, José F. (Org.). Políticas Públicas e Desenvolvimento: bases epistemológicas e modelos de análise. Brasília: Editora da Universidade de Brasília, 2a edição, 2010.

HÖFLING, Eloisa de Mattos. Estado e políticas (públicas) sociais. Cadernos Cedes, ano XXI, n. 55, novembro 2001.

GONÇALVES, M. F. Novas configurações no desenvolvimento urbano paulista. Revista Espaço e Debates. São Paulo, no 38, pp. 39-53, 1994.

GOTTDIENER, Mark. A Produção Social do Espaço Urbano. 2 ed., São Paulo: Editora da Universidade de São Paulo, 1997, 310 p.

JACOBS, Jane. Morte e Vida de Grandes Cidades, (Tradução - Carlos S. Mendes Rosa). São Paulo: Martins Fontes, 2000, 510p. Original: The Death and Life of Great American Cities, 1961.

JAKOB, Alberto Augusto Eichman; CUNHA, José Marcos Pinto da. Delimitação de áreas de segregação espacial da população na mancha urbana da Região Metropolitana de Campinas a partir de imagens de satélite e técnicas de estatística espacial. In: XII SIMPósIO BRASILEIRO DE SENSORIAMENTO REMOTO. Anais... Goiânia: Abril de 2005, INPE, p. 3771-3778.

KOWARICK, Lucio. A espoliação urbana. São Paulo, 1979, Paz e Terra.

LEFEBVRE, H. O direito à cidade. São Paulo: Ed. Documentos Ltda., 1968.

LIMA, Renato da Silva. Expansão urbana e acessibilidade: o caso das cidades médias brasileiras. Dissertação de Mestrado (1998). São Carlos - EESC/ USP

LYNCH, Kevin. A imagem da cidade. São Paulo: Martins Fontes, 1999. 
MARCUSE, Peter. 0 caso contra os direitos de propriedade. In Valença, Marcio (org.) Cidade (i)legal. Rio de Janeiro. Mauad, 2008, pp 9-20.

MARICATO, Erminia (Org.). A produção capitalista da casa (e da cidade) no Brasil industrial. $2^{\mathrm{a}}$ ed., São Paulo: Editora Alfa-omega, 1982.

MARICATO, Ermínia. As Tragédias Urbanas: desconhecimento, ignorância ou cinismo? Revista Caros Amigos, 17 jan., 2011 .

. Metrópoles Desgovernadas. In Estudos Avançados 25 (71), $2011 \mathrm{~b}$.

. Metrópole na periferia do capitalismo: ilegalidade desigualdade e violência. São Paulo, publicação FAU USP, julho de 1995.

. A Política Habitacional do Regime Militar. Petrópolis: Vozes, 1987.

O impasse da política urbana no Brasil. Petrópolis: Vozes, 2011c.

MELO, Marcus André B. C. Políticas públicas e habitação popular: continuidade e ruptura, 1979 - 1988. In: RUA, Salvador, 2 (2): 37-59, 1989.

MERLIN, Jose Roberto; SANTOS JUNIOR, Wilson Ribeiro dos; QUEIROGA, E. F.; BENFATTI, Denio Munia. Os instrumentos atuais de planejamento urbano: limites e conflitos na apropriação dos sistemas de espaços livres da Região Metropolitana de Campinas. In: TÂNGARI, Vera; ANDRADE, Rubens de; SCHLEE, Mônica. (Org.). Sistema de espaços livres: o cotidiano, apropriações e ausências. Rio de Janeiro. Rio de Janeiro: Universidade Federal do Rio de Janeiro, 2009, v. , p. 182-194.

MITICA NETO, Hélio. Tecidos urbanos dispersos na Região Metropolitana de Campinas. In: REIS, Nestor Goulart. Dispersão Urbana: Diálogos sobre pesquisas Brasil - Europa. São Paulo: FAU - USP, 2007.

MORETTI, Ricardo de Sousa. Desafios da Solução Habitacional em um Quadro de Desigualdades. In: SOUZA, Maria Adélia (Org.). A Metrópole e o Futuro - Refletindo sobre Campinas. Campinas: Edições Territorial, v. 1, p. 245-253, 2008.

MORETTI, R. S.; JANNUZZI, P. M. . Política Habitacional na Região Metropolitana de Campinas. In: 2a Conferência Municipal de Habitação, 2004, Campinas. HabitaçãoPlenárias Temáticas. Campinas: COHAB- Campinas, 2004. p. 1-15.

NASCIMENTO, José Carlos Pereira do. A Contradição entre a cidade e a metrópole campineira. Relatório de Pesquisa apresentado ao programa de pós-graduação em Geografia Humana em DG/ FFLCH/ USP. São Paulo: FFLCH/ USP, 1999.

NEGRI, Barjas. Concentração e desconcentração industrial em São Paulo (18801990). Campinas: editora da UNICAMP, 1996. 242 p.

o Desafio de Implementar o Estatuto da Cidade: Oficinas de Capacitação (DVD). Coordenação: Eglaisa Micheline Pontes Cunha. Oficinas: 01 - José Roberto Bassul, 02Ermínia Maricato e Laura M de Mello Bueno, 03 - Erminia Maricato e João Whaitaker S. Ferreira, 04 - Raquel Rolnik, 05 - Nabil Bonduki, 06 - Helena Menna Barreto, 07 - Paula Freire Santoro, 08 - Cláudia Pilla Damasio, 09 - Sonia Rabello de Castro, 10 - Fernanda Furtado, 11 - Paulo Sandroni, 12 - Cintia Estefania Fernandes, 13 - Celso Santo Carvalho e Denise de Campos Gouvêa. Ministério das Cidades, 2007. 
PASTERNAK, Suzana. Política Habitacional no Brasil: retrospectivas e perspectivas. Cadernos de Pesquisa do LAP, São Paulo, n.21, 1998.

PATAPOFF, Patrícia (s/d). "Desenvolvimento Econômico e Urbanização: Estudo de Caso do Município de Americana". Monografia de Graduação, UNICAMP.

PEQUENO, R. Políticas habitacionais, favelização e desigualdades sócio-espaciais nas cidades brasileiras: transformações e tendências. Barcelona, 2008.

PIRES, Maria Conceição Silvério. Mercado imobiliário e a expansão urbana pós-1990 na Região Metropolitana de Campinas. In: MENDONÇA, Jupira Gomes e COSTA, Heloisa Soares de Moura (orgs.). Estado e capital imobiliário: convergências atuais na produção do espaço urbano brasileiro. Belo Horizonte: C/Arte, 2011.

Morar na Metrópole: expansão urbana e mercado imobiliário na Região Metropolitana de Campinas. Tese (Instituto de Geociências, Universidade Estadual de Campinas), Campinas, 2007.

PORTAS, Nuno. Tendências do Urbanismo na Europa. Revista Óculum. Campinas, FAUPUCCAMP, no 3, março de 1993.

QUEIROGA, E. F.; BENFATTI, Denio Munia. Entre o Nó e a Rede, dialéticas espaciais contemporâneas: o caso da metrópole de Campinas diante da Megalópole do Sudeste do Brasil. In: Revista Brasileira de Estudos Urbanos e Regionais (ANPUR), v. 9, p. 41-52, 2007.

QUEIROGA, E. F.; MERLIN, Jose Roberto; SANTOS JUNIOR, Wilson Ribeiro dos; SILVA, J. M. P. . Espaços livres e esfera pública na metrópole contemporânea: a Região Metropolitana de Campinas - SP. In: CAMPOS, A.; QUEIROGA, E.; GALENDER, F.; DEGREAS, H.; AKAMINE, R.; MACEDO, S.; CUSTÓDIO, V.. (Org.). Quadro dos sistemas de espaços livres nas cidades brasileiras. $1^{\mathrm{a}}$ ed. São Paulo: FAUUSP, 2012, v. , p. 171-194.

QUEIROGA, Eugenio Fernandes. Produção da paisagem habitacional metropolitana: três estudos de caso no município de Osasco - SP. São Paulo, 1994. Dissertação (Mestrado)

REIS, Nestor Goulart; PORTAS, Nuno e TANAKA, Marta Soban. Dispersão Urbana: Diálogos sobre pesquisas Brasil - Europa. São Paulo: FAU-USP, 2007.

REIS, Nestor Goulart e TANAKA, Marta Soban. Brasil: Estudos sobre dispersão Urbana. São Paulo: FAU-USP, 2007.

REIS, Nestor Goulart. Notas sobre urbanização dispersa e novas formas de tecido urbano. São Paulo: Via das Artes, 2006. 201 p.: il.

REIS Filho, Nestor Goulart. Habitação Popular no Brasil: 1880-1920. Cadernos de Pesquisa do LAP. São Paulo: FAU-USP, nº 1, Julho/Agosto, 1994.

. Sobre a história da Urbanização - história urbana. In: Espaços e Debates. 1991. v.11, n.34, p.15-8, 1991.

Notas sobre a organização das regiões metropolitanas. São Paulo Fauusp, 1996. 60p. Cadernos de Pesquisa do Lap, 12.

. Urbanização e planejamento no Brasil - 1960/1983. São Paulo Fauusp 1996. 62p Cadernos de Pesquisa do Lap, 11. 
. Apropriação do solo urbano e política habitacional. São Paulo FAU-USP, 1996. 54 p. Cadernos de Pesquisa do LAP, 14.

RIBEIRO, Luiz Cesar de Queiroz. Dos Cortiços aos Condomínios de Luxo. Rio de Janeiro: Civilização Brasileira, 1996.

RIBEIRO, Joana Aparecida Zavaglia M. T. O espaço da terra na política habitacional análise do plano municipal de habitação de Campinas. In: Anais do XV ENanpur, Recife, 2013.

. Os "nós" da terra na política habitacional na Região Metropolitana de Campinas. Dissertação de Mestrado. Pós-graduação em Urbanismo na da Pontifícia Universidade Católica de Campinas, Campinas, 2014.

ROBERTO, Braga; CARVALHO, Pompeu Figueiredo de (org.) Estatuto da Cidade: Política Urbana e Cidadania. Deplan, 2000.

Ferramentas para avaliação da inserção urbana dos empreendimentos do MCMV. Rede Cidade e Moradia. Chamada MCTI/CNPq/MCIDADES No 11/2012. Equipe: Laboratório Espaço Público e Direito à Cidade (LabCidade), coord. Raquel Rolnik. Faculdade de Arquitetura e Urbanismo da Universidade de São Paulo (FAU-USP). Disponível em: <http://www.labcidade.fau.usp.br/arquivos/relat\%C3\%B3rio.pdf>. Acesso em: jun. de 2015. 2014.

ROLNIK, Raquel. A Cidade e a lei. São Paulo: FAPESP/NOBEL, 1997.

Regulação urbanística e exclusão territorial. Revista Polis, São Paulo, Instituto Pólis, n. 32, 1999.

ROYER, Luciana de Oliveira. Financeirização da política habitacional: limites e perspectivas. Tese de Doutorado. FAU/USP. São Paulo, 2009.

RUA, Maria das Graças. Análise de Políticas Públicas: Conceitos Básicos. In: RUA, Maria das Graças; VALADÃO, Maria Izabel. O Estudo da Política: Temas Selecionados. Brasília: Paralelo 15, 1998.

RIZEK, Cibele Saliba. A Moradia. São Carlos: Revista Risco - SAP/ EESC/ USP, 2006.

. Os sentidos da cidade brasileira: figuração da ordem e seus avessos. Espaço \& Debates, São Paulo, v. 43-44, p. 79-91, 2003.

RIZEK, C. S.; SHIMBO, L. Z. . A produção da cidade e de suas representações: das ideias clássicas às inflexões recentes. In: J. F. B. Freiras e E. M. S. Mendonça. (Org.). A construção da cidade e do urbanismo: as ideias têm lugar?. 1ed.Vitoria: EDUFES, 2012, v. 1 , p. $189-203$.

RZEZINSKI, Henrique Costa (consultor do Banco Mundial); SCHWEIZER, Peter José (consultor da OEA e da ONU). Habitação popular no Brasil: uma mudança na ação governamental. In: International Journal for Development Technology, vol. 3, 1985.

SAMORA, Patricia Rodrigues. Projetos de habitação e favelas: especificidades e parâmetros de qualidade. Tese de Doutorado. Faculdade de Arquitetura e Urbanismo - USP. São Paulo, 2009.

SAMPAIO, Maria Ruth Amaral de. Metropolização: um estudo da habitação popular paulistana. São Paulo: tese de doutorado apresentada à FAU-USP, 1972. 
SANTORO, Paula Freire; COBRA, Patricia Lemos; BONDUKI, Nabil. Cidades que crescem horizontalmente: o ordenamento territorial justo da mudança de uso rural para urbano. Cad. Metróp., São Paulo, v.12, n. 24, p. 417 - 440, jul-dez, 2010.

SANTOS JUNIOR, Orlando Alves; MONTANDON, Daniel Todtmann (orgs.). Os Planos Diretores Municipais Pós-Estatuto da Cidade: balanço crítico e perspectivas. Rio de Janeiro: Letra Capital, Observatório das Cidades, IPPUR/UFRJ, 2011.

SANTOS, Milton e SILVEIRA, Maria Laura. O Brasil: Território e Sociedade no Início do Século XXI. 5 ed., Rio de Janeiro: Record, 2001.

SANTOS, Cláudio Hamilton M. Políticas federais de habitação no Brasil: 1964/1998. Texto para discussão n. 654. Brasília, 1999.

SCHERER, R.. Pesquisa bibliográfica sobre a rede urbana paulista no período de expansão da economia cafeeira. São Paulo, 1991, FAU-USP.

SCHNEIDER, Ingrid Elisabeth. Confrontos e dificuldades na implementação dos instrumentos urbanísticos propostos nos Planos Diretores Municipais de Campinas na década de 90. São Paulo: FAU-USP, 2002. Dissertação de Mestrado.

SECCHI, Leonardo. Políticas Públicas: Conceitos, Esquemas de Análise, Casos Práticos. São Paulo: Cengage Learning, 2010.

SEMEGHINI, Ulysses Cidade. Gestão Metropolitana, possibilidades e limites: A experiência de Campinas. Campinas, UNICAMP, Instituto de Economia, 2006. 135 p. Tese de Doutorado.

1991.

. Do Café à Indústria: uma cidade e seu tempo. Campinas: Editora da Unicamp,

SEMEGHINI, E. C. \& ARAÚJO, M. F. Municípios Paulistas: crescimento recente e trajetórias alternativas. Revista São Paulo em Perspectiva, Fundação SEADE, v3, n.3, São Paulo 1989.

SERRA, G G. Rodovias , Conurbação e dispersão urbana. 1993. In: Documentos em Síntese, v.2 , n.6 , p.5-7, jul. 1993. Artigo de Periódico. FAU - Faculdade de Arquitetura e Urbanismo.

SERRAN, João Ricardo. O IAB e a política habitacional. São Paulo: Schema, 1976.

SILVA, Gustavo Resgala. O papel do Estado na produção da Periferia Norte, a partir da implantação dos conjuntos habitacionais Cristina e Palmital, Santa Luzia - RMBH. In: MENDONÇA, Jupira Gomes; COSTA, Heloisa Soares de Moura (orgs.). Estado e capital imobiliário: convergências atuais na produção do espaço urbano brasileiro. Belo Horizonte: C/Arte, 2011.

SILVA, Jonathas Magalhães Pereira. Habitação de interesse social e as legislações municipais da região metropolitana de Campinas. In: Ambiente Construído, Porto Alegre, v. 11 , n. 3, p. 55-71, jul./set. 2011 a.

Relatório de Pesquisa apresentado à PUC-Campinas. Campinas, 2011b.

SILVA, Jonathas Magalhães Pereira da; MAGALHÃES, Natália Cristina Trípoli. Contradições da Região Metropolitana de Campinas - Delimitação das ZEIS e a localização dos 
investimentos públicos em habitação de interesse social. Arquitextos, São Paulo, ano 14, n. 158, Vitruvius, agosto, 2013.

SILVA, Kleber Pinto. Planos urbanos, legislação urbanística e forma urbana: Campinas um estudo. In: Boletim do Centro de Memória da Unicamp, Vol. $6 \mathrm{n}^{\circ}$ 11. Campinas: CMU/ UNICAMP, 1994.

SILVA, Paula Francisca F. A expansão urbana de Campinas através de condomínios e loteamentos fechados (1974 - 2005). Dissertação (Mestrado apresentado à Faculdade de Arquitetura e Urbanismo), EESC/USP, São Carlos, 2008.

Articulação das Políticas Públicas Habitacionais na Região Metropolitana de Campinas. In: MARTINS, Maria Lúcia Refinetti et al. CIUDADES EN TRANSFORMACIÓN: Gobierno, Mercado y Conflictividad Social: Medellín-Colombia, São Paulo y Campinas-Brasil (XV Enanpur). Apresentação oral, XV ENANPUR, Recife - PE, 2013.

- Os meandros do instrumento ZEIS da concepção até a produção de habitações de interesse social - o caso da Região Metropolitana de Campinas (Sessão Temática 7: Dinâmica imobiliária, habitação e regulação urbana). In: Anais do XVI ENANPUR Encontro Nacional da ANPUR, Belo Horizonte, 2015.

ANAIS do XV Encontro Nacional da Associação Nacional de Pós Graduação e Pesquisa em Planejamento Urbano e Regional, 2013.

SILVA, Ricardo Alexandre; BUENO, Laura Machado de Mello. Injustiça Urbana e Ambiental: O planejamento de "Zonas de Sacrifício". In: Anais do XV ENanpur, Recife, 2013.

SOUZA, Marcelo Lopes. O Desafio Metropolitano. Rio de Janeiro: Bertrand Brasil, 2000.

SOUZA, Maria Adélia. A Identidade da Metrópole. Hucitec, Edusp, São Paulo, 1994.

TEIXEIRA, Denise. Flávio Villaça. Entrevista, São Paulo, 06.024, Vitruvius, out 2005 <http://www.vitruvius.com.br/revistas/read/entrevista/06.024/3309>.

VALLADARES, Licia do Prado. Estudos recentes sobre a habitação no Brasil: resenha da literatura. In: (org). Repensando a habitação no Brasil. Rio de Janeiro: Zahar, 1982.

VALLADARES, Licia do Prado (org.). Habitação em questão. Rio de Janeiro: Zahar, 1980.

VIÉGAS, R. N.. Desigualdade Ambiental e "Zonas de Sacrifício". Rio de Janeiro: FASE/IPPUR (Artigo publicado no Mapa dos Conflitos Ambientais no estado do Rio de Janeiro), 2006.

VERDI, Adriana Renata. Metropolização de Campinas: possibilidades no entorno da grande São Paulo. São Paulo, 1997. 188 p. Dissertação (Mestrado). Geografia.

VILLAÇA, Flávio. As ilusões do Plano Diretor. Acesso em: www.usp.br/fau/fau/galeria/paginas/index.html. São Paulo, edição do autor. 2005.

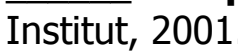

Espaço Intra-urbano no Brasil. São Paulo: Studio Nobel/ FAPESP/ Lincoln

O que Todo Cidadão Precisa Saber sobre Habitação. Disponível em: <http://www.flaviovillaca.arq.br/livros01.html>, acessado em 27/11/2013, São Paulo: Global Editora, 1986. 
Uma Contribuição para a história do planejamento urbano no Brasil. In: DEÁK, Csaba; SCHIFFER, Sueli Ramos (orgs.). O Processo de Urbanização no Brasil. São Paulo: Editora da Universidade de São Paulo, 1999.

WONG, Laura Rodríguez. Região de Campinas: o surgimento de uma nova área metropolitana. São Paulo: SEADE, 1983. 68 p.: il.

ZAHN, Carlos Eduardo. Regiões metropolitanas em formação: Campinas e Santos. São Paulo: Sep/Shdu/Emplasa, 1990. Parte de monografia/ livro, p. 143-8. Faculdade de Arquitetura e Urbanismo - USP.

\section{Legislacão, Planos e Políticas Federais}

Plano Nacional de Habitação de dez/ 2009.

Política Nacional de Habitação de Nov/ 2004.

- BRASIL. Lei 4.380, de 21 de agosto de 1964. Institui a correção monetária nos contratos imobiliários de interesse social, o sistema financeiro para aquisição da casa própria, cria o Banco Nacional da Habitação (BNH), e Sociedades de Crédito Imobiliário, as Letras Imobiliárias, o Serviço Federal de Habitação e Urbanismo e dá outras providências. Diário Oficial da União, Brasília, DF, 30 set. 1964. Disponível em: <http://www.planalto.gov.br/ccivil_03/leis/L4380.htm> Acesso em: 4 de setembro de 2013.

- BRASIL. Lei 11.124, de 16 de junho de 2005. Dispõe sobre o Sistema Nacional de Habitação de Interesse Social - SNHIS, cria o Fundo Nacional de Habitação de Interesse Social - FNHIS e institui o Conselho Gestor do FNHIS. Diário Oficial da União, Brasília, DF, 17 jun. 2005. Disponível em: <http://www.planalto.gov.br/ccivil_03/_ato20042006/2005/lei/l11124.htm>. Acesso em: 4 de setembro de 2013.

- BRASIL. Lei 5.796, de 6 de junho de 2006. Regulamenta a Lei $n^{\circ} 11.124$, de 16 de junho de 2005, que dispõe sobre o Sistema Nacional de Habitação de Interesse Social - SNHIS, cria o Fundo Nacional de Habitação de Interesse Social - FNHIS e institui o Conselho Gestor do FNHIS. Diário Oficial da União, Brasília, DF, 7 jun. 2006. Disponível em: <http://www.planalto.gov.br/ccivil_03/_Ato2004-2006/2006/Decreto/D5796.htm> Acesso em: 4 de setembro de 2013.

- BRASIL. Lei no 12.424, de 16 de junho de 2011. Altera a Lei $n^{\circ} 11.977$, de 7 de julho de 2009, que dispõe sobre o Programa Minha Casa, Minha Vida - PMCMV e a regularização fundiária de assentamentos localizados em áreas urbanas [...]. Diário Oficial da União, Brasília, DF, 17 jun. 2011. Disponível em <http://www.planalto.gov.br/ccivil_03/_ato20112014/2011/lei/l12424.htm>. Acesso em: 4 de novembro de 2014.

- BRASIL. Lei no 11.977, de 7 de julho de 2009. Dispõe sobre o Programa Minha Casa, Minha Vida - PMCMV e a regularização fundiária de assentamentos localizados em áreas urbanas [...]. Diário Oficial da União, Brasília, DF, 8 jul. 2009. Disponível em <http://www.planalto.gov.br/ccivil_03/_ato2007-2010/2009/lei/l11977.htm>. Acesso em: 4 de novembro de 2014.

- BRASIL. Constituição (1988). Constituição da República Federativa do Brasil. Brasília, DF: Senado, 1988.

- BRASIL. Estatuto da Cidade. Lei no 10.257, de 10 de julho de 2001. Diário Oficial da União, Brasília, DF, 11 jul. 2001. Disponível em: 
<http://www.planalto.gov.br/ccivil_03/leis/leis_2001//10257.htm>. Acesso em: 4 de novembro de 2014.

- BRASIL. Estatuto da Metrópole. Lei no 13.089, de 12 de janeiro de 2015. Diário Oficial da União, Brasília, DF, 13 jan. 2015. Disponível em: http://www.planalto.gov.br/ccivil_03/leis/leis_2001/l10257.htm. Acesso em: 28 de fevereiro de 2015.

- BRASIL. Lei Complementar no 24, de 8 de junho de 1973. Estabelece as regiões metropolitanas de São Paulo, Belo Horizonte, Porto Alegre, Recife, Salvador, Curitiba, Belém e Fortaleza. Diário Oficial da União, Brasília, DF, 11 jun. 1973. Disponível em <http://www.planalto.gov.br/ccivil_03/leis/LCP/Lcp14.htm>. Acesso em: 4 de novembro de 2014.

\section{Legislação, Planos e Políticas do Estado e da RMC}

Plano Metropolitano de Habitação de Interesse Social. AGEMCAMP - Agência Metropolitana de Campinas. Disponível em: <http://www.agemcamp.sp.gov.br/midia/plano_metropolitano_habitacao-2010.pdf>. Acesso em: 14 de out. de 2013. 2010.

Plano Diretor de Gestão de Resíduos Sólidos da Região Metropolitana de Campinas. AGEMCAMP - Agência Metropolitana de Campinas. Disponível em: < http://www.agemcamp.sp.gov.br/midia/plano_diretor_residuossolidos_rev.outubro2009.pdf > . Acesso em: 10 de nov. de 2015. Julho de 2009.

- Constituição Estadual de São Paulo, 05 de outubro de 1989.

- Lei Estadual no 12.801 de 15 de janeiro de 2008 - "Autoriza o Poder Executivo a adotar medidas visando à participação do Estado no Sistema Nacional de Habitação de Interesse Social - SNHIS, cria o Conselho Estadual de Habitação - CEH, institui o Fundo Paulista de Habitação de Interesse Social - FPHIS e o Fundo Garantidor Habitacional - FGH, e dá providências correlatas".

- Lei Complementar Estadual no 815 de 30 julho de 1996 - cria a Região Metropolitana da Baixada Santista.

- Lei Complementar Estadual no 870 de 19 julho de 2000 - cria a Região Metropolitana de Campinas.

- Lei Complementar Estadual no 1.166 de 09 de janeiro de 2012 - cria a Região Metropolitana do Vale do Paraíba e Litoral Norte.

- Lei Complementar Estadual no 1.241 de 09 de maio de 2014 - cria a Região Metropolitana de Sorocaba. 


\section{Legislações, Planos e Políticas dos Municípios da RMC}

\section{Americana}

- Lei Complementar no 4.597 de 1 de fevereiro de 2008 - Plano Diretor.

- Lei no 4.196 de 3 de agosto de 2005 - dispõe sobre a política de habitação, institui o Fundo Municipal de Habitação e cria seu Conselho.

- Lei no 4.632 de 8 de maio de 2008 - altera a Lei 4.196/05.

- Lei 4.731 de 7 de novembro de 2008 - altera a Lei 4.196/05.

- Decreto no 9.147 de 14 de setembro de 2011 - altera a composição do Conselho Municipal de Habitação de Interesse Social.

- Decreto no 9.853 de 5 de outubro de 2012 - altera a composição do Conselho.

- Lei 4.731 de 7 de novembro de 2008 - altera a Lei 4.196/05

\section{$\underline{\text { Artur Nogueira }}$}

- Lei Complementar no 441 de 3 de abril de 2007 - Plano Diretor.

- Lei no 2.959 de 14 de dezembro de 2009 - cria o Fundo Municipal de Habitação e o seu Conselho gestor e dispõe sobre a Conferência Municipal de Habitação.

\section{Campinas}

- Lei Complementar nº 15 de 27 de dezembro de 2006 - Plano Diretor.

- Lei no 10.410 de 17 de janeiro de 2000 - regulamenta os Empreendimentos Habitacionais de Interesse Social em Campinas.

- Lei no 11.464 de 10 de janeiro de 2003 - cria o Conselho Municipal de Habitação.

- Decreto 14.225 de 18 de março de 2003 - institui o Conselho Municipal de Habitação.

- Lei 14.428 de 09 de setembro de 2003 - dispõe sobre o regimento interno do Conselho Municipal de Habitação de Interesse Social.

- Lei 10.616 de 14 de setembro de 2000 - institui o Fundo Municipal de Habitação

- Lei no 14.901 de 2001 de 08 de setembro de 2004 - estabelece normas operacionais relativas à execução orçamentária e financeira do Fundo Municipal de Habitação.

\section{Cosmópolis}

- Lei Complementar no 2.949 de 03 de janeiro de 2007 - Plano Diretor.

- Lei Complementar no 3.390 de 29 de agosto de 2011 - Lei de Uso e Ocupação do Solo (mapa anexo com o zoneamento e delimitação das ZEIS).

- Lei no 3.010 de 22 de janeiro de 2008 - cria o Fundo Municipal de Habitação de Interesse Social e institui o seu Conselho gestor. 
- Lei no 3.074 de 18 de novembro de 2008 - altera a composição do Conselho gestor do Fundo Municipal de Habitação: inclui membros da associação de moradores de bairros.

- Lei no 3.534 de 13 de setembro de 2013 - acrescenta mais um membro ao Conselho: membro da Associação dos Produtores Rurais de Cosmópolis (APRUC), alterando a Lei $3.074 / 2008$.

\section{Engenheiro Coelho}

- Lei Complementar nº 11 de 28 de junho de 2012 - Plano Diretor.

\section{$\underline{\text { Holambra }}$}

- Lei Complementar nº 183 de 25 de abril de 2007 - Plano Diretor.

- Lei no 732 de 31 de maio 2011 - cria o Fundo Municipal de Habitação e institui o seu Conselho.

\section{Hortolândia}

- Lei Complementar no 2.092 de 04 de julho de 2008 - Plano Diretor.

- Lei no 1.905 de 21 de junho de 2007 - "dispõe sobre Empreendimentos Habitacionais de Interesse Social e estabelece normas sobre habitação popular no município de Hortolândia".

- Lei no 1.592 de 22 de novembro de 2005 - "dispõe sobre a constituição do Conselho Municipal de Habitação, a Conferência Municipal de Habitação, a criação do Fundo Municipal de Habitação e dá outras providências".

- Lei no 1.972 de 10 de dezembro de 2007 - altera a Lei 1.592/07, regulamentando sobre a composição do Conselho e o Fundo Municipal de Habitação.

- Decreto no 2.165 de 14 de dezembro de 2009 - regulamenta o regimento do Conselho Municipal de Habitação.

- Lei 2.561 de 26 de maio de 2011 - altera a Lei 1.592/05 sobre a composição do Conselho Municipal de Habitação.

\section{Indaiatuba}

- Lei Complementar nº 09 de 22 de outubro de 2010 - Plano Diretor.

- Lei Complementar no 10 de 22 de outubro de 2010 - "Dispõe sobre a alteração, atualização, revisão e consolidação da lei $n^{\circ} 4.066$, de 24 de setembro de 2001, que dispõe sobre o ordenamento do uso e da ocupação do solo do Município de Indaiatuba, e dá outras providências."

- Lei Complementar no 21 de 19 de julho de 2013 - altera as leis que abordam o ordenamento do uso e ocupação do solo.

- Lei no 5.261 de 21 de dezembro de 2007 - altera e acresce dispositivos à Lei 3.919/07 que dispõe sobre o Conselho de Habitação sobre o e institui o Fundo.

- Lei no 3.919 de 13 de setembro de 2000 - "dispõe sobre a constituição de Conselho Municipal de Habitação e institui o Fundo Municipal de Habitação a ele vinculado e dá outras providências". 


\section{Itatiba}

- Lei Complementar no 4.325 de 20 de janeiro de 2011 - Plano Diretor.

- Lei no 4.443 de 01 de fevereiro de 2012 - dispõe sobre o uso e ocupação do solo.

- Lei no 4.119 de 09 de dezembro de 2008 - cria o conselho e institui o fundo municipal de habitação.

- Decreto no 5.696 de 23 de julho de 2009 - aprova o regimento do conselho municipal de habitação.

- Decreto no 6.006 de 12 de agosto de 2011 - dispõe sobre a composição do conselho municipal de habitação.

\section{Jaguariúna}

- Lei Complementar no 204 de 19 de janeiro de 2012 - Plano Diretor.

- Lei Complementar no 97 de 20 de dezembro de 2004 - dispõe sobre o parcelamento, uso e ocupação do solo no município.

- Lei Complementar no 233 de 02 de setembro de 2013 - altera a lei 97/2004 sobre parcelamento, uso e ocupação do solo no município.

- Lei nº 1.886 de 22 de abril de 2009 - cria o Conselho e Fundo Municipais de Habitação.

\section{Monte Mor}

- Lei Complementar nº 16 de 05 de novembro de 2010 - Plano Diretor.

- Lei Complementar no 17 de 05 de novembro de 2010 - dispõe sobre o ordenamento do uso e ocupação do solo de Monte Mor.

- Lei no 1.431 de 16 de novembro de 2009 - cria o fundo municipal de Habitação de Interesse Social e institui o seu conselho gestor.

\section{Morungaba}

- Lei no 1.159 de 06 de novembro de 2006 - institui o Plano Diretor.

- Lei no 1.364 de 19 de outubro de 2010 - altera os anexos II e III do plano diretor, sendo o anexo III o mapa do zoneamento, com as ZEIS.

\section{Nova Odessa}

- Lei Complementar no 10 de 06 de outubro de 2006 - Plano Diretor.

- Lei Complementar no 33 de 28 de agosto de 2013 - altera o zoneamento do Plano Diretor.

- Lei no 2.258 de 14 de dezembro de 2007 - cria o conselho e institui o fundo municipal de habitação.

- Lei no 2491 de 05 de maio de 2011 - altera a Lei 2.258/07 sobre o conselho e fundo municipais de habitação. 


\section{Paulínia}

- Lei Complementar no 2.852 de 22 de dezembro de 2006 - Plano Diretor.

- Lei Complementar no 54 de 28 de dezembro de 2012 - Lei de Parcelamento, Uso e Ocupação do Solo.

- Lei no 3.012 de 31 de agosto de 2009 - cria o Fundo Municipal de Habitação e institui o seu Conselho.

- Lei no 3.048 de 28 de dezembro de 2009 - altera a Lei 3.012/2009.

\section{Pedreira}

- Lei Complementar nº 2.792 de 25 de março de 2008 - Plano Diretor.

- Lei 2.708 de 29 de maio de 2007 - cria o fundo municipal de habitação e institui o seu conselho gestor.

- Lei nº 295 de 13 de abril de 2009 - altera o Conselho Municipal de Habitação.

- Lei no 300 de 30 de abril de 2009 - nomeia membros representantes do Fundo Municipal de Habitação e Desenvolvimento Urbano de Interesse Social.

- Lei no 3.068 de 06 de outubro de 2010 - cria Zonas Habitacionais de Interesse Social (ZHIS).

\section{Santa Bárbara d'Oeste}

- Lei Complementar no 28 de 08 de novembro de 2006 - Plano Diretor.

- Lei Municipal no 3.670 de 22 de outubro de 2014 - dispõe sobre normas para parcelamento e urbanização de glebas com fins de habitação de interesse social.

- Lei 3.297 de 29 de junho de 2011 - aprova e institui o Plano Municipal de Habitação de Interesse Social, cria o Fundo Municipal de Habitação e institui o seu conselho, visando a participação no SNHIS.

\section{Santo Antônio de Posse}

- Lei Complementar nº 17 de 11 de outubro de 2006 - Plano Diretor.

- Lei Complementar no 16 de 30 de setembro de 2010 - dispõe sobre o uso e ocupação do solo (estabelece o zoneamento).

- Lei no 2731 de 14 de novembro de 2012 - cria o fundo municipal de Habitação de Interesse Social e institui o seu conselho gestor. 


\section{Sumaré}

- Lei no 4.250 de 06 de outubro de 2006 - Plano Diretor.

- Lei 2.831 de 26 de dezembro de 1995 - dispõe sobre o parcelamento, uso e ocupação do solo do Município de Sumaré.

- Lei no 4.545 de 27 de dezembro de 2007 - dispõe sobre a Política de Habitação do município, institui a Conferência Municipal de Habitação, reestrutura o Conselho Municipal de Habitação e cria o Fundo Municipal de Desenvolvimento Habitacional.

- Lei no 5172 de 28 de abril de 2011 - altera a Lei 4.545/07.

$\underline{\text { Valinhos }}$

- Lei Complementar nº 3.841 de 21 de dezembro de 2004 - Plano Diretor.

- Lei no 4.186 de 10 de outubro de 2007 - dispõe sobre a ordenação e uso do solo (e sobre o zoneamento).

- Lei 4.375 de 08 de dezembro de 2008 - institui o Conselho e Fundo Municipais de Habitação.

\section{Vinhedo}

- Lei Complementar no 66 de 17 de janeiro de 2007 - Plano Diretor.

- Lei no 3.057 de 13 de dezembro de 2007 - cria o Fundo Municipal de Habitação e seu conselho gestor.

- Lei Complementar no 123 de 22 de julho de 2013 - Institui a Zona de Interesse Social 2 e altera parâmetros da Lei Complementar 66/2007.

- Lei Complementar no 136 de 01 de abril de 2015 - revoga a Lei Complementar 123/2013 e altera o anexo X da Lei Complementar 66/2007. 


\section{Anexos}

\section{Coletânea das Regulamentações Municipais da RMC}

Foram coletadas as seguintes legislações dos 19 municípios da Região Metropolitana de Campinas (RMC): Fundo Municipal de Habitação, Conselho Municipal de Habitação, Plano Local de Habitação de Interesse Social, planos diretores e seus anexos. Para a compreensão das questões habitacionais, em alguns municípios da RMC houve a necessidade de se ampliar este levantamento, buscando as Leis de Uso e Ocupação do solo, zoneamento e outras complementares, como leis específicas que instituem as ZEIS (Zonas Especiais de Interesse Social).

Cabe ressaltar que a obtenção desse material, a princípio público, foi bastante difícil, principalmente os anexos das legislações, especialmente os mapas. Desta forma este levantamento ocorreu a partir do acesso aos sites oficiais das prefeituras e das câmaras municipais e foi complementado por meio de contato via e-mail, telefone e, em alguns casos, visitas aos municípios.

Toda essa legislação e alguns mapas coletados estão em um CD na última folha desta tese. O levantamento foi sistematizado em pastas, a partir dos nomes dos municípios para facilitar a pesquisa.

\section{Mapa em arquivo digital das HIS realizadas na RMC entre 1964 e 2014}

Conforme apresentado no Capítulo IV deste trabalho, foram levantados 504 conjuntos de Habitação de Interesse Social nos vinte municípios da Região Metropolitana de Campinas.

Esses dados de fonte primária, obtidos nas prefeituras dos vinte municípios da RMC foram utilizados para a localização desses conjuntos, totalizando 494 conjuntos mapeados. Assim, os dados dos levantamentos, observados na Tabela 6 a Tabela 25 (p. 76 a p. 113), podem também ser verificados no mapa digital que localiza essas HIS.

Esse mapa, com os perímetros das HIS realizadas entre 1964 e 2014 nos municípios da RMC e seus dados está disponível em CD anexo na última folha desta tese. 